KELLY DE ARAÚJO RODRIGUES

\title{
USO DE REATORES BIOLÓGICOS COM FUNGOS PARA REMOÇÃO DE FENOL DE ÁGUA RESIDUÁRIA SINTÉTICA.
}

Tese apresentada à Escola de Engenharia de São Carlos, da Universidade de São Paulo, como parte dos requisitos para obtenção do título de Doutor em Hidráulica e Saneamento.

ORIENTADORA: Prof ${ }^{\mathrm{a}}$ Dra. Sandra Tédde Santaella CO-ORIENTADOR: Prof. Dr. Marcelo Zaiat

São Carlos 
Ficha catalográfica preparada pela Seção de Tratamento da Informação do Serviço de Biblioteca - EESC/USP

Rodrigues, Kelly de Araújo

Uso de reatores biológicos com fungos para remoção de fenol de água residuária sintética / Kelly de Araújo Rodrigues. -- São Carlos, 2006.

Tese (Doutorado) -- Escola de Engenharia de São Carlos-Universidade de São Paulo, 2006.

Área: Hidráulica e Saneamento.

Orientador: Profa. Dra. Sandra Tédde Santaella.

Co-orientador : Prof. Dr. Marcelo Zaiat.

1. Aspergillus niger. 2. Fenol. 3. Tratamento biológico. 4. Água residuária sintética. I. Titulo. 
À minha mãe, Maria do Socorro (Maninha), pelo exemplo de fé em Deus, paciência e humildade. 


\section{AGRADECIMENTOS}

A Jesus Cristo por sua fidelidade, amor e misericórdia, por me fazer crer no impossível e me fortalecer nos momentos mais difíceis. O Seu amor me constrange...

Aos meus pais, Zé Carlos e Socorro (Maninha), pelo amor, incentivo, dedicação e apoio incondicional.

Ao Conselho Nacional de Pesquisa e Desenvolvimento - CNPq, pela concessão da bolsa e pelo financiamento da pesquisa através do Edital Universal, Processo $475375 / 2001-7$.

À professora Sandra Tédde Santaella pela orientação. Obrigada pela sua visão ao buscar o suporte financeiro para custear esta pesquisa, pela idéia do trabalho de doutorado e por ter me incentivado e ajudado a dar os primeiros passos na minha formação científica.

Ao professor Marcelo Zaiat pela co-orientação, por sua atenção, humanidade, simplicidade, generosidade e disposição constante em ajudar. Muito obrigada pelo carinho, pelas palavras de incentivo e apoio e pela torcida. Obrigada por acreditar na minha capacidade profissional, pois foi muito importante para que eu pudesse chegar até aqui. 
Às amigas, Glória Marinho, Denise Conceição (Dezinha) e Iolanda (Tininha) pela força, carinho, conselhos, incentivo e companheirismo. Obrigada pelo apoio de todas as horas e pela amizade sincera.

Às professoras Dra. Iracema Helena Crusius e Dra. Regina Monteiro pela ajuda e esclarecimento de dúvidas, em determinados períodos deste trabalho.

Às biólogas Iolanda Cristina Duarte e Luísa Helena Oliveira pela ajuda com as análises de microbiologia e identificação dos fungos.

A Ana Paula Paim, técnica do LATAR (Laboratório de Tratamento Avaçado de Águas Residuárias) na época da realização das análises, pelo exemplo de profissionalismo, pela atenção e por sua disposição constante em ajudar. Obrigada pela amizade, apoio, carinho e conselhos.

À Maria Ângela Talarico, técnica do LPB (Laboratório de Processos Biológicos), pela atenção, carinho, torcida e incentivo.

À professora Beth Moraes (Bethinha), por quem tenho enorme carinho e respeito, por sua ajuda ao longo desta pesquisa, não apenas na cromatografia, mas também pelos esclarecimentos de dúvidas, pelas sugestões e, principalmente, por seu grande coração. Obrigada pelo carinho, torcida e incentivo.

Aos técnicos do Laboratório de Saneamento, Paulo, Júlio e Cidinha pela atenção e cordialidade.

Ao técnico do Laboratório de Resíduos Sólidos, Vadinho, pela atenção e convivência pacífica durante a operação dos reatores. 
Aos amigos Ana Rosa, Danielli Granado, Denise, Luciana Hespanholo e Wesley (Filé) pela amizade, carinho, companheirismo e pelos inesquecíveis momentos de alegria e descontração na República do Barão do Rio das Flores.

Aos amigos Adelaide, Brás, Fernanda, Marcelo e Vanderlice (Lice), Marlene, Valderez e Zé Mauro por terem me acolhido no calor de sua amizade, pelo carinho, pelos ensinamentos e, principalmente, pelas orações.

À Vanderlice (Lice) Mizuno pelo exemplo de fé, por sua paciência e por me ajudar a prosseguir e a confiar mais do que querer entender os propósitos de Deus.

A todos os colegas de laboratório e do Departamento de Hidráulica e Saneamento, companheiros ou não, pelo aprendizado de vida durante estes quatro anos de doutorado. Acreditem, foi uma escola... Com um carinho especial aos amigos: Ariovaldo (Ari), Arnaldo, Betão, Bruna, Cristina, Dalva, Fernandão e Karina, Gláucio, Iolanda (Tininha), Isabel, Kátia (Dâmia), Leonardo (Seu Leo), Leonídia, Lorena, Luana, Orlando, Rogério Herlon, Rogério Michelan e Romina, dos quais levo grande saudade.

À Pavi, Sá e Rose pela maneira cordial e atenciosa com que sempre me receberam e pela disposição em ajudar.

À Rose e dona Terezinha pela amizade e carinho.

À Sandra Tédde Santaella e Raimundo de Oliveira Souza por terem me ajudado em um momento muito difícil e me encorajado a seguir em frente e a fazer o doutorado.

À Heloneida Sousa por seu coração sempre sensível, pelos longos anos de amizade e pelo apoio em todas as horas. 
Aos professores Bernadete Varesche, Marcelo Zaiat, Marco Reali, Maria do Carmo Calijuri e José Roberto Campos pelo conhecimento transmitido durante as disciplinas. Em especial à profa. Bernadete pelas oportunidades de falar sobre meu trabalho em sua disciplina.

Às famílias Marinho e Sampaio pela acolhida, carinho, apoio e amizade.

À Rossana Barros e Iolanda Duarte pela ajuda com a tradução do abstract.

Aos colegas do CEFET: Benedita, Bemvindo, Paulinho, Mabel e Rossana pela acolhida e pelas palavras de incentivo.

A todos que contribuíram direta ou indiretamente para a realização deste trabalho. 
Hoje finalizo uma grande jornada. Uma caminhada que se iniciou em meio a uma turbulência pessoal, mas que significava muito para mim...

Significava a chance de recomeçar, de crescer e de continuar, de fazer perguntas sobre os porquês que tanto nos inquietam no meio da pesquisa e de realizar o sonho de hoje estar aqui.

O caminho não foi fácil, nada fácil, mas o de quem o é?

Lembro-me das palavras do professor Tininho que certa vez disse ter encontrado muitos espinhos em seu caminho e que desejava que o nosso caminho fosse mais suave...

O meu não foi, mas novamente pergunto, o de quem o é?

E acho mesmo que é melhor assim, pois nos força a caminhar sempre em frente, a transpor as barreiras, a cair e nos levantar, saber engolir o choro e recuar na hora certa e levantar para vencer. Isto nos torna mais fortes, nos faz melhores do que éramos quando iniciamos a jornada, porque não existe crescimento sem dor e eu cresci...

Eu estou feliz, muito feliz mesmo, pois estou aqui finalizando o que há quatro anos e dois meses iniciei e mais feliz ainda porque antes mesmo deste grande final, eu venci. Não apenas por mim, mas por todos que acreditaram e torceram por mim, até mesmo pelos que torceram contra.

Tudo valeu, tudo foi bom, tudo mesmo, porque tudo contribuiu para que hoje eu pudesse estar aqui, com acertos e erro.. Talvez até mais erros que acertos, mas valeu demais!

Bom, eu quero mesmo é agradecer.

Tenho muito a agradecer, muito mais do que a reclamar.

Agradecer ao meu amado Deus que com todas as minhas imperfeições soube me conduzir até este momento, tornando meu caminho perfeito, como tinha de ser, com flores e espinhos.

Agradecer aos meus pais que não estão aqui, mas que me ajudaram a escrever a minha história. Fico muito feliz de ver o quanto de alegria e conforto vejo nos olhos deles pelas minhas vitórias.

Agradecer aos amigos, aos amigos mesmo, pelos momentos de alegria, de apoio, de brincadeiras e de companheirismo. Como ter vivido estes quatro anos sem ter pessoas tão especiais e queridas ao meu lado?Ainda que alguns não estivessem fisicamente ao meu lado.... Vocês se tornaram a minha família. Não preciso citar nomes, pois vocês 
estão no meu coração e sei que eu no de vocês. Foi muito bom e sei que ainda será, pois as amizades verdadeiras como as poucas que fiz aqui, sei que são para uma vida toda e isto é maravilhoso, não é?

Agradecer à Sandra Santaella, pois sem ela eu também não estaria aqui. Na verdade, tudo começou com ela. Graças a você, Sandra, eu pude me tornar melhor, mais forte, mais guerreira e me tornar vitoriosa, não só por hoje, mas por tudo que vivi durante este tempo. Com você aprendi que a gente tem de matar um leão a cada dia e não é fácil... Mas valeu! Pois pude chegar até aqui,eu pude vencer.

Agradecer a uma pessoa especial que me ajudou a acreditar que eи era capaz, apesar de seu grande sonho ao longo destes quatro anos ter sidoo de me deportar para Fortaleza. Pois é Zaiat, finalmente você conseguiu! Antes tarde que nunca, né? Mas ainda bem que foi só agora... Também, eu enchi mesmo teu saco, não te deixei em paz um só momento. Desde a época das disciplinas, lá estava eu (ah! A Glória também). Mas fui eu quem ficou e de tanto que te atazanei, não teve jeito, você teve de me adotar. E você o fez da melhor forma, sem nenhuma distinção entre mim e os que eram realmente seus... Mas mais que isso, fica o que aprendi de mais importante com você. Aprendi que um grande professor é aquele que consegue ser um educador, alguém que nos fascina com sua inteligência e carisma e nos conquista com sua humanidade e senso de compreender as coisas que estão ao nosso redor. Com seu jeito político e conciliador... Você é dez! Não que seja perfeito, você tem defeitos... Mas se eu conseguir ser como professora, pesquisadora e orientadora pelo menos um terço do que você é, estarei mais que feliz.

Agradecer a professoras Regina e Iracema que mesmo sem me conhecer não hesitara em me estender as mãos e me ensinaram que um pesquisador de verdade tem de ser generoso, pois a pesquisa só tem valor quando é compartilhada. E vocês são incrivelmente generosas.

A você Regina, o agradecimento se estende um pouco mais, porque você foi e é mais que generosa comigo. Desde o primeiro encontro parecia que já te conhecia a um tempão, porque você é assim, simples... Você é daquelas pessoas que faz agente se sentir amiga de longas datas. Exala simplicidade de tal forma que encanta.

Espero que continuemos juntas e generosas, compartilhando o conhecimento e eu mais que ninguém aprendendo com vocês.

Agradecer aos professores que tive (e eu já falei de você Zaiat), mas fica a admiração especial também por duas professoras. A Maria do Carmo, ah! não tem nem como 
comparar, ela é única como professora, dona de um carisma que petrifica e de um conhecimento e de uma força que nos faz admirá-la, é inevitável.

E a Bernadete... No início, eu achava tão estranha aquela risada dela.... mas hoje sinto saudade. Passei a admirá-la pela sua alegria e vitalidade, pelo carinho que dispensa a todos. A Berna é espontânea, real ... Até nos parecemos em algumas coisas, somos explosivas, não curtimos muito essa de levar desaforo para casa... Ela também acreditou que eu era capaz, acreditou em mim e eu aprendi com ela que agente tem de melhorar sempre, ter disposição para aprender sempre.

Não posso me esquecer dos funcionários, mas embora fique chato falar em nomes, não posso me deixar de mencionar. Agradeço o carinho da Rose, sempre bem humorada. Saudades que sinto da dona Terê que sabe de tudo, vê tudo, um verdadeiro baú, dona de um coração enorme. Como não agradecer seu carinho durante todo este tempo?

À Pavi e a Sá, mas estas já são legendárias aqui.

Não posso me esquecer das minhas queridas Beth, Janja e Ana Paula Paim. Ah!

Quantas saudades eu levo de vocês! Como não agradecer? Vocês me ajudaram a prosseguir em minha pesquisa, não teria conseguido sem o conhecimento e a generosidade de vocês.

Enfim, foram tantas as pessoas que me ajudaram nesta caminhada....

Mas, como disse, hoje finalizo uma caminhada. Apenas uma, mais uma, pois graças a vocês todos, eu também começo outra, uma outra ainda maior e tenho certeza que melhor, pois levo dentro de mim tudo que aprendi com vocês.

Obrigada, obrigada mesmo por tudo...

Tudo valeu apena, tudo foi bom!!!

Obrigada.

Kelly Rodrigues 
Deus é Fiel! 


\section{RESUMO}

RODRIGUES, K. A. (2006). Uso de reatores biológicos com fungos para remoção de fenol de água residuária sintética. São Carlos, SP. Tese (Doutorado) - Escola de

Engenharia de São Carlos, Universidade de São Paulo.

Os compostos fenólicos estão presentes em grande número de efluentes industriais, cujos lançamentos inadequados podem acarretar em riscos ao meio ambiente e à saúde humana. $\mathrm{O}$ uso de fungos em reatores biológicos é uma alternativa de tratamento de despejos que possuem compostos persistentes, como fenóis. O objetivo deste trabalho foi estudar a viabilidade do uso de Aspergillus niger em reator biológico para o tratamento de água residuária sintética contendo fenol. $\mathrm{O}$ trabalho foi realizado com dois tipos de reatores: em batelada e reatores contínuos com escoamento ascendente. No experimento em batelada, foram utilizados 5 reatores de controle (RC), 5 com fungos (RF) e 5 com fungos e glicose (RFG), verificando-se o uso de glicose (5 g/L), como substrato primário, e a remoção do fenol pelos fungos. Estes apresentaram maior desenvolvimento nos reatores contendo glicose (RFG), alcançando-se remoção de $100 \%$ de fenol, no quinto e último dia de experimento. Nestes reatores, a velocidade média de consumo de fenol foi quase o dobro da desenvolvida nos reatores sem glicose (RF). A remoção de matéria orgânica, medida como DQO, foi superior nos reatores contendo glicose (RFG) e atingiu 93\%, no quinto dia. Não houve remoção significativa de fenol nos reatores de controle. Nos RF, as maiores remoções de fenol e matéria orgânica foram registradas no quinto dia e foram, respectivamente, de $48 \%$ e $27 \%$. As maiores remoções de fenol em relação à de matéria orgânica indicam, possivelmente, a presença de compostos intermediários da degradação do fenol. Os reatores contínuos, cada um com volume total de 4,45 $\mathrm{L}$ e com meios suportes de manta de polipropileno $\left(\mathrm{R}_{1}\right)$ e espuma de poliuretano $\left(\mathrm{R}_{2}\right)$, foram mantidos sob as mesmas condições operacionais, durante 399 dias, divididos em três tempos de detenção hidráulica: $8 \mathrm{~h}$, dividido em duas fases de alimentação (Fase I - alimentação complementada com glicose e Fase II alimentação sem complementação de glicose); 4 h e $6 \mathrm{~h}$. As maiores remoções de fenol ocorreram durante o tempo de detenção hidráulica (TDH) de $8 \mathrm{~h}$, tanto com a presença ou não de $0,5 \mathrm{~g} / \mathrm{L}$ de glicose no afluente, obtendo-se, na Fase I, remoções médias de fenol de $99,5 \% \pm 2\left(R_{1}\right)$ e de $98 \% \pm 5\left(R_{2}\right)$ e, na Fase II, $99,6 \% \pm 1\left(R_{1}\right)$ e $92 \% \pm 23$ $\left(\mathrm{R}_{2}\right)$. No tempo de detenção hidráulica de $4 \mathrm{~h}$, a remoção média de fenol ficou em torno de $50 \%$, em ambos os reatores. Com o tempo de detenção hidráulica de $6 \mathrm{~h}$, houve melhora na eficiência de remoção, atingindo $72 \% \pm 35\left(\mathrm{R}_{1}\right)$ e $78 \% \pm 25\left(\mathrm{R}_{2}\right)$. Análises microscópicas revelaram que os fungos cresceram bem nos suportes empregados, porém o uso de espuma de poliuretano provocou maiores problemas operacionais. Apesar dos bons resultados de remoção de matéria orgânica e de fenol, houve crescimento excessivo de biomassa no interior dos reatores contínuos, o que resultou na colmatação do leito, indicando necessidade de se procurar melhor ajuste nutricional do meio para controlar a geração de biomassa.

Palavras-chave: água residuária sintética, Aspergillus niger, fenol, fungos, reatores biológicos. 


\begin{abstract}
RODRIGUES, K. A. (2006). The use of biological reactors containing fungi to remove phenol from synthetic wastewater. São Carlos, SP. Thesis (Ph.D.) - School of Engineering of São Carlos, University of São Paulo.
\end{abstract}

The phenolic compounds are present in a great quantity in industrial effluents, which inappropriate release can cause serious damage to the environment and to human health. The usage of fungi in biological reactors is an alternative to the treatment of wastes that contain compounds with persistent nature like phenol.

The goal of this work was the study of the available usage of Aspergillus niger in a biological reactor treating synthetic wastewater containing phenol.

The work was realized in batch and upflow continuous reactors. Five control reactors (CR) were applied in the batch experiment, being five with fungi (FR) and five with fungi and glucose (GFR), in order to verify the application of glucose $(5 \mathrm{~g} / \mathrm{L})$ as main substrate and the removal of phenol by fungi

These presented better development in the reactors containing glucose, with the achievement of $100 \%$ of phenol removal in the fifth and last day of the experiment. In these reactors, the mean consumption velocity of phenol was approximately the double of those that were developed in the reactors without glucose.

The organic matter removal (measured as COD) was higher in the reactors containing glucose, achieving $93 \%$ in the fifth day. There was no significant phenol removal in the control reactors.

The higher removals of $48 \%$ for phenol and $27 \%$ for organic matter were observed in the RF reactors in the fifth day, indicating the possible presence of intermediate compounds in the phenol degradation.

The continuous reactors were built with total volume of $4,45 \mathrm{~L}$ each one, with polypropylene blanket as support media in the R1 reactor and polyurethane foam as support media in the $\mathrm{R} 2$ reactor. The reactors were kept in the same operational conditions during 399 days. These conditions were divided in three hydraulic detention times (HDT): $8 \mathrm{~h}$, divided in two feeding phases (Phase I - feeding complemented with glucose and Phase II - feeding without complementation of glucose); $4 \mathrm{~h}$ and $6 \mathrm{~h}$. The higher phenol removals occurred during the hydraulic detention time of $8 \mathrm{~h}$, in the presence and absence of $0,5 \mathrm{~g} / \mathrm{L}$ of glucose in the influent. The mean phenol removals of $99,5 \% \pm 2\left(\mathrm{R}_{1}\right)$ and $98 \% \pm 5\left(\mathrm{R}_{2}\right)$ were attained in the Phase $\mathrm{I}$, and $99,6 \% \pm 1\left(\mathrm{R}_{1}\right)$ and $92 \% \pm 23\left(\mathrm{R}_{2}\right)$ in the Phase II.

The mean phenol removal was around $50 \%$ in both reactors when hydraulic detention time of $4 \mathrm{~h}$ was applied. With the hydraulic detention time of $6 \mathrm{~h}$, there was improvement in the removal efficiency that achieved $72 \% \pm 35$ for $\mathrm{R}_{1}$ reactor and $78 \%$ \pm 25 for $R_{2}$ reactor. The microscopic analyses showed that fungi grew well in the applied support media, but the usage of polyurethane foam caused more operational problems. Even with the good results of the organic matter and phenol removals, there was excessive growth of biomass inside the reactors. This resulted in the clogging of the blanket, indicating the necessity of better nutritional adjustment of the media to control the biomass generation.

Keywords: synthetic wastewater, Aspergillus niger, phenol, fungi, biological reactors. 


\section{LISTA DE FIGURAS}

Figura 3.1: Fórmula estrutural do fenol 4

Figura 3.2: Rota aeróbia de degradação do fenol. 20

Figura 4.1: Reatores de leito fixo e escoamento ascendente: com meio suporte de manta de polietileno $\left(\mathrm{R}_{1}\right)$ e espuma de poliuretano $\left(\mathrm{R}_{2}\right)$. 38

Figura 5.1: Remoção de matéria orgânica, expressa em DQO, nos reatores de controle

(RC), com fungos (RF) e com fungos e glicose (RFG), ao longo da batelada. 45

Figura 5.2: Remoção de fenol nos reatores de controle (RC), com fungos (RF) e com fungos e glicose (RFG), ao longo da batelada. 46

Figura 5.3: Remoção de glicose nos reatores com fungos e glicose (RFG), ao longo da batelada.

Figura 5.4: Ajuste das concentrações normalizadas de fenol obtidas nos reatores com fungos e glicose (RFG) (a) e com fungos sem glicose (RF) (b), ao longo da batelada.

Figura 5.5: Variação da velocidade de consumo de fenol durante o ensaio em batelada nos reatores com fungos e glicose (RFG) (a) e com fungos (RF) (b).

Figura 5.6: Variação do $\mathrm{pH}$ nos reatores de controle (RC), com fungos (RF) e com fungos e glicose (RFG).

Figura 5.7: Microscopia da biomassa no interior dos reatores: (a) RF desmontado no segundo dia da batelada - estrutura vesicular, de onde partem os esporos; (b) e (c) detalhe do Aspergillus niger nos reatores RFG desmontados no quinto dia.

Figura 5.8: Reatores com biofilme aderido ao meio suporte de $\mathrm{R}_{1}$ (a) - manta de polipropileno - e $\mathrm{R}_{2}$ (b) - espuma de poliuretano.

Figura 5.9: Variações das concentrações de matéria orgânica, medida em DQO, no afluente e efluente do reator com meio suporte de manta de polipropileno $\left(\mathrm{R}_{1}\right)$, no TDH de 8 h, na Fase I (alimentação com glicose).

Figura 5.10: Variações das concentrações de matéria orgânica, medida em DQO, no afluente e efluente do reator com meio suporte de espuma de poliuretano $\left(\mathrm{R}_{2}\right)$, com TDH de 8 h, na Fase I (alimentação com glicose).

Figura 5.11: Variações das eficiências de remoção de matéria orgânica, medida em DQO, no afluente e efluente do reator com meio suporte de manta de polipropileno $\left(\mathrm{R}_{1}\right)$, no TDH de $8 \mathrm{~h}$, na Fase I (alimentação com glicose).

Figura 5.12: Variações das eficiências de remoção de matéria orgânica, medida em DQO, no afluente e efluente do reator com meio suporte de espuma de poliuretano $\left(\mathrm{R}_{2}\right)$, no TDH de $8 \mathrm{~h}$, na Fase I (alimentação com glicose).

Figura 5.13: Variações das concentrações de fenol no afluente e efluente do reator com meio suporte de manta de polipropileno $\left(\mathrm{R}_{1}\right)$, no TDH de $8 \mathrm{~h}$ e Fase I (alimentação com glicose).

Figura 5.14: Variações das concentrações de fenol no afluente e efluente do reator com meio suporte de espuma de poliuretano $\left(\mathrm{R}_{2}\right)$, no TDH de $8 \mathrm{~h}$ e Fase I (alimentação com glicose).

Figura 5.15: Variações das concentrações de AGV no efluente do reator com meio suporte de manta de polipropileno $\left(\mathrm{R}_{1}\right)$, no TDH de $8 \mathrm{~h}$, Fase I (alimentação com glicose).

Figura 3.16: Variações das concentrações de AGV no efluente do reator com meio suporte de espuma de poliuretano $\left(\mathrm{R}_{2}\right)$, no TDH de $8 \mathrm{~h}$, Fase I (alimentação com glicose). 
Figura 5.17: Variações do $\mathrm{pH}$ no afluente e efluente do reator com meio suporte de manta de polipropileno $\left(\mathrm{R}_{1}\right)$, no TDH $8 \mathrm{~h}$, Fase I (alimentação com glicose).

Figura 5.18: Variações do $\mathrm{pH}$ no afluente e efluente do reator com meio suporte de espuma de poliuretano $\left(\mathrm{R}_{2}\right)$, no TDH 8 h, Fase I (alimentação com glicose).

ura 5.19: Variações das concentrações de OD no afluente e efluente do reator com meio suporte de manta de polipropileno $\left(\mathrm{R}_{1}\right)$, TDH 8 h, Fase I (alimentação com glicose).

Figura 5.20: Variações das concentrações de oxigênio dissolvido no afluente e efluente do reator com meio suporte de espuma de poliuretano $\left(\mathrm{R}_{2}\right)$, TDH $8 \mathrm{~h}$, Fase I (alimentação com glicose).

Figura 5.21: Variações das concentrações de matéria orgânica, medida em DQO, no afluente e efluente do reator com manta de polipropileno $\left(\mathrm{R}_{1}\right)$, no TDH $8 \mathrm{~h}$, Fase II (alimentação sem glicose).

Figura 5.22: Variações das concentrações de matéria orgânica, medida em DQO, no afluente e efluente do reator com espuma de poliuretano $\left(\mathrm{R}_{2}\right)$, no TDH 8 h, Fase II (alimentação sem glicose).

Figura 5.23: Variações das eficiências de remoção de matéria orgânica, medida em DQO, no afluente e efluente do reator com manta de polipropileno $\left(\mathrm{R}_{1}\right)$, no TDH 8 h, Fase II (alimentação sem glicose).

Figura 5.24: Variações das eficiências de remoção de matéria orgânica, medida em DQO, no afluente e efluente do reator com espuma de poliuretano $\left(\mathrm{R}_{2}\right)$, no TDH 8

h, Fase II (alimentação sem glicose).

Figura 5.25: Reator com meio suporte de espuma de poliuretano $\left(\mathrm{R}_{2}\right)$ : onde pode ser observada a zona morta por compressão do meio suporte.

Figura 5.26: Variações das concentrações de fenol no afluente e efluente do reator com meio suporte de manta de polipropileno $\left(\mathrm{R}_{1}\right)$, no TDH 8 h, Fase II (alimentação sem glicose).

Figura 5.27: Variações das concentrações de fenol no afluente e efluente do reator com meio suporte de espuma de poliuretano $\left(\mathrm{R}_{2}\right)$, no TDH 8 h, Fase II (alimentação sem glicose).

Figura 5.28: Variações do $\mathrm{pH}$ no afluente e efluente do reator com meio suporte de manta de polipropileno $\left(\mathrm{R}_{1}\right)$, no TDH 8 h, Fase II (alimentação sem glicose).

Figura 5.29: Variações do $\mathrm{pH}$ no afluente e efluente do reator com meio suporte de espuma de poliuretano $\left(\mathrm{R}_{2}\right)$, no TDH 8 h, Fase II (alimentação sem glicose).

Figura 5.30: Variações das concentrações de AGV no efluente do reator com meio suporte de manta de polipropileno $\left(\mathrm{R}_{1}\right)$, no TDH de 8 h, Fase II (alimentação sem glicose).

Figura 5.31: Variações das concentrações de AGV no efluente do reator com meio suporte de espuma de poliuretano, $\left(\mathrm{R}_{2}\right)$, no TDH de 8 h, Fase II (alimentação sem glicose).

Figura 5.32: Variações das concentrações de OD no afluente e efluente do reator com meio suporte de manta de polipropileno $\left(\mathrm{R}_{1}\right)$, no TDH 8 h, Fase II (alimentação sem glicose).

Figura 5.33: Variações das concentrações de OD no afluente e efluente do reator com suporte de espuma de poliuretano $\left(\mathrm{R}_{2}\right)$, no TDH 8 h, Fase II (alimentação sem glicose).

Figura 5.34: Variação da concentração de matéria orgânica, medida em DQO, do afluente e efluente do reator com manta de polipropileno $\left(\mathrm{R}_{1}\right)$, no TDH de $4 \mathrm{~h} . \quad 80$

Figura 5.35: Variação da concentração de matéria orgânica, medida em DQO, do afluente e efluente do reator com espuma de poliuretano $\left(\mathrm{R}_{2}\right)$, no TDH de $4 \mathrm{~h} . \quad 80$ 
Figura 5.36: Variações das eficiências de remoção da matéria orgânica, medida em DQO, do afluente e efluente do reator com manta de polipropileno $\left(\mathrm{R}_{1}\right)$, no TDH de $4 \mathrm{~h}$.

Figura 5.37: Variações das eficiências de remoção da matéria orgânica, medida em DQO, do afluente e efluente do reator com espuma de poliuretano $\left(\mathrm{R}_{2}\right)$, no TDH de $4 \mathrm{~h}$.

Figura 5.38: Variações das concentrações de fenol no afluente e efluente do reator com manta de polipropileno $\left(\mathrm{R}_{1}\right)$, no TDH de $4 \mathrm{~h}$.

Figura 5.39: Variações das concentrações de fenol no afluente e efluente do reator com espuma de poliuretano $\left(\mathrm{R}_{2}\right)$, no TDH de $4 \mathrm{~h}$.

Figura 5.40: Variações das concentrações de OD no afluente e efluente do reator com manta de polipropileno $\left(\mathrm{R}_{1}\right)$, no TDH de $4 \mathrm{~h}$.

Figura 5.41: Variações das concentrações de OD no afluente e efluente do reator com espuma de poliuretano $\left(\mathrm{R}_{2}\right)$, no TDH de $4 \mathrm{~h}$.

Figura 5.42: Variações do $\mathrm{pH}$ no afluente e efluente do reator com manta de polipropileno $\left(\mathrm{R}_{1}\right)$, no $\mathrm{TDH}$ de $4 \mathrm{~h}$.

Figura 5.43: Variações do $\mathrm{pH}$ no afluente e efluente do reator com espuma de poliuretano $\left(\mathrm{R}_{2}\right)$, no TDH de $4 \mathrm{~h}$.

Figura 5.44: Variações das concentrações de matéria orgânica, medida em DQO, no afluente e efluente do reator com manta de polipropileno $\left(\mathrm{R}_{1}\right)$, no TDH de $6 \mathrm{~h} . \quad 87$

Figura 5.45: Variações das concentrações de matéria orgânica, medida em DQO, no afluente e efluente do reator com espuma de poliuretano $\left(\mathrm{R}_{2}\right)$, no TDH de $6 \mathrm{~h} . \quad 88$

Figura 5.46: Variações das eficiências de remoção da matéria orgânica, medida em DQO, no afluente e efluente do reator com manta de polipropileno $\left(\mathrm{R}_{1}\right)$, no TDH de $6 \mathrm{~h}$.

Figura 5.47: Variações das eficiências de remoção da matéria orgânica, medida em DQO, no afluente e efluente do reator com espuma de poliuretano $\left(\mathrm{R}_{2}\right)$, no TDH de $6 \mathrm{~h}$.

Figura 5.48: Variações das concentrações de fenol, no afluente e efluente do reator com manta de polipropileno $\left(\mathrm{R}_{1}\right)$, no TDH de $6 \mathrm{~h}$.

Figura 5.49: Variações das concentrações de fenol, no afluente e efluente do reator com espuma de poliuretano $\left(\mathrm{R}_{2}\right)$, no TDH de $6 \mathrm{~h}$.

Figura 5.50: Variações das eficiências de remoção de matéria orgânica, medida em DQO, e de fenol, no reator $\mathrm{R}_{1}$, durante o experimento de escoamento contínuo. 91

Figura 5.51: Variações das eficiências de remoção de matéria orgânica, medida em DQO, e de fenol, no reator $\mathrm{R}_{2}$, durante o experimento de escoamento contínuo. 92

Figura 5.52: Variações do $\mathrm{pH}$ no afluente e efluente dos reatores com meio suporte de manta de polipropileno $\left(\mathrm{R}_{1}\right)$, no TDH de $6 \mathrm{~h}$.

Figura 5.53: Variações do $\mathrm{pH}$ no afluente e efluente do reator com meio suporte de espuma de poliuretano $\left(\mathrm{R}_{2}\right)$, no TDH de $6 \mathrm{~h}$.

Figura 5.54: Variações das concentrações de OD, no afluente e efluente do reator com manta de polipropileno $\left(\mathrm{R}_{1}\right)$, no TDH de $6 \mathrm{~h}$.

Figura 5.55: Variações das concentrações de OD, no afluente e efluente do reator com espuma de poliuretano $\left(\mathrm{R}_{2}\right)$, no TDH de $6 \mathrm{~h}$.

Figura 5.56: Manchas escuras nos reatores com fungos, no final do experimento de escoamento contínuo.

Figura 5.57: Microrganismos desprendidos da manta de polipropileno: (a) Aspergillus niger e leveduras; (b) Hifa de Aspergillus niger; (c) Alargamento da hifa; (d) Material gelatinoso envolvendo o micélio. 
Figura 5.58: Microrganismos desprendidos da espuma de poliuretano: (a) Hifa submersa em material gelatinoso; (b) Fragmento de hifas de Aspergillus niger e leveduras.

Figura 5.59: MEV (microscopia eletrônica de varredura) dos microrganismos aderidos ao meio suporte de manta de polipropileno (reator $\mathrm{R}_{1}$ ): (a) Hifas de Aspergillus niger; (b) Hifa de Aspergillus niger.

Figura 5.60: MEV (microscopia eletrônica de varredura) dos microrganismos aderidos ao meio suporte de espuma de poliuretano (reator $\mathrm{R}_{2}$ ): (a) Aspergillus niger; (b) Hifa de Aspergillus niger. 


\section{LISTA DE TABELAS}

Tabela 3.1: Propriedades físicas do fenol 5

Tabela 3.2: Macronutrientes e sua função no metabolismo fúngico. $\quad 10$

Tabela 3.3: Micronutrientes e sua função no metabolismo fúngico. 12

Tabela 3.4: Imobilização natural ou auto-imobilização de espécies fúngicas em meios suportes. $\quad 16$

Tabela 3.5: Estudos sobre o uso de espécies fúngicas na remoção de vários compostos.

Tabela 3.6: Uso de Aspergillus niger na remoção de poluentes. 29

Tabela 4.1: Composição da água residuária sintética 34

Tabela 4.2: Tempo de duração do ensaio em batelada. 35

Tabela 4.3: Tempos de detenção hidráulica aos quais foram submetidos os reatores com meio suporte de manta de polipropileno $\left(\mathrm{R}_{1}\right)$ e de espuma de poliuretanpo $\left(\mathrm{R}_{2}\right)$, em função do volume útil. $\quad 39$

Tabela 4.4: Variáveis determinadas e métodos utilizados. 42

Tabela 4.5: Reagentes empregados para determinação das concentrações de amônia, nitrato e fósforo, realizada por FIA. 43

Tabela 5.1: Concentração de fenol adsorvido no micélio presente nos reatores com fungos (RF) e com fungos e glicose (RFG). $\quad 50$

Tabela 5.2: Características da água residuária sintética com fenol 54

Tabela 5.3: Relações de C/N de substratos empregados em trabalhos com fungos em reatores biológicos. $\quad 74$

Tabela 5.4: Dados de adsorção de fenol no meio suporte de manta de polipropileno $\left(\mathrm{R}_{1}\right)$.

Tabela 5.5: Massas de fenol removidas durante a operação do reator com meio suporte de manta de polipropileno $\left(\mathrm{R}_{1}\right)$

Tabela 5.6: Dados de adsorção de fenol no meio suporte de espuma de poliuretano $\left(\mathrm{R}_{2}\right)$.

Tabela 5.7: Massas de fenol removidas durante a operação do reator com meio suporte de espuma de poliuretano $\left(\mathrm{R}_{2}\right)$

Tabela 5.8: Concentrações médias de fenol nos efluentes dos reatores com meio suporte de manta de polipropileno $\left(\mathrm{R}_{1}\right)$ e espuma de poliuretano $\left(\mathrm{R}_{2}\right)$ 


\section{LISTA DE ABREVIAÇÕES E SÍMBOLOS}

\begin{tabular}{|c|c|}
\hline $\mathrm{AGV}$ & Ácidos graxos voláteis \\
\hline $\mathrm{C}_{\mathrm{o}}$ & Concentração inicial ou na entrada \\
\hline $\mathrm{C}$ & Concentração final \\
\hline $\mathrm{C}_{\mathrm{e}}$ & Concentração na saída \\
\hline $\mathrm{C} / \mathrm{N}$ & Relação carbono: nitrogênio \\
\hline MEV & Microscopia eletrônica de varredura \\
\hline Q & Vazão \\
\hline $\mathrm{R}_{1}$ & $\begin{array}{l}\text { Reator com meio suporte de manta de } \\
\text { polipropileno }\end{array}$ \\
\hline $\mathrm{R}_{2}$ & Reator com meio suporte de espuma de poliuretano \\
\hline $\mathrm{RC}$ & Reator de controle \\
\hline $\mathrm{RF}$ & Reator com fungos \\
\hline RFG & Reator com fungos e glicose; \\
\hline $\mathrm{r}_{\mathrm{S}}$ & Velocidade de consumo de substrato \\
\hline $\mathrm{TDH}$ & Tempo de detenção hidráulica \\
\hline $\mathrm{r}_{\text {média }}$ & Velocidade média de consumo de substrato \\
\hline $\mathrm{r}_{\max }$ & Velocidade máxima de consumo de substrato \\
\hline$\Delta \mathrm{t}$ & Variação de tempo \\
\hline $\mathrm{t}_{\mathrm{o}}$ & Tempo inicial \\
\hline $\mathrm{t}$ & Tempo final \\
\hline$\varepsilon$ & Porosidade do leito \\
\hline$\mu_{\text {máx }}$ & Velocidade máxima de crescimento microbiano \\
\hline$\varnothing$ & Diâmetro \\
\hline
\end{tabular}




\section{SUMÁRIO}

1. INTRODUÇÃO

2. OBJETIVOS 3

2.1 Objetivo Geral 3

2.2 Objetivos Específicos 3

3. REVISÃO BIBLIOGRÁFICA 4

3.1 Águas Residuárias Contendo Compostos Fenólicos e Processos de Tratamento

3.2 Principais Características e Fisiologia dos Fungos

$\begin{array}{ll}3.3 \text { Crescimento de biofilmes de fungos em meios suportes } & 13\end{array}$

$\begin{array}{ll}3.4 \text { Mecanismos de remoção de poluentes por fungos } & 17\end{array}$

3.5 Emprego dos Fungos no Tratamento de Águas Residuárias Contendo

Compostos Persistentes $\quad 22$

4. MATERIAL E MÉTODOS 33

4.1 Escolha da Espécie de Fungo para Inóculo dos Reatores 34

4.2 Inóculo 34

4.3 Composição da Água Residuária Sintética $\quad 34$

4.4 Reatores em batelada $\quad 35$

4.4.1 Tratamento dos Dados Cinéticos 36

4.5 Reatores Contínuos de Leito Fixo 37

$\begin{array}{ll}\text { 4.5.1 Meios Suportes } & 37\end{array}$

$\begin{array}{ll}\text { 4.5.2 Reatores } & 37\end{array}$

$\begin{array}{ll}\text { 4.5.3 Porosidade do leito } & 39\end{array}$

4.5.4 Ensaio de Adsorção nos Meios Suportes $\quad 40$

4.5.5 Adição do inóculo e alimentação dos reatores 41

4.5.6 Microscopia 41

4.5.7 Métodos empregados para determinação das variáveis $\quad 42$

4.5.7.1 Determinação do fenol adsorvido e armazenado 43

5. RESULTADOS E DISCUSSÃO 45

5.1 Batelada 45

5.2 Operação dos Reatores Contínuos de Leito Fixo 54

5.2.1 Caracterização da Água Residuária Sintética 54

5.2.2 Germinação dos esporos 54

5.2.3 Operação dos reatores com TDH de $8 \mathrm{~h}$ - alimentação com glicose (Fase I)

5.24 Operação dos reatores TDH de $8 \mathrm{~h}$ - alimentação sem glicose (Fase II) 65

$\begin{array}{ll}\text { 5.2.5 Operação dos reatores nos TDH de } 4 \mathrm{~h} . & 79\end{array}$

$\begin{array}{ll}\text { 5.2.6 Operação dos reatores TDH de } 6 \mathrm{~h} & 87\end{array}$

5.2.7 Considerações sobre a remoção do fenol 96

5.2.8 Ensaio de Adsorção nos Meios Suportes 98

5.2.9 Exames Microscópicos 102

5.2.10 Comparação das eficiências médias de remoção de fenol nos TDH estudados em relação ao CONAMA (2005) 105

6. CONCLUSÕES E RECOMENDAÇÕES 106

6.1 CONCLUSÕES 106

6.2. RECOMENDAÇÕES 107

7. REFERÊNCIAS BIBLIOGRÁFICAS 109 


\section{INTRODUÇÃO}

A contaminação do ambiente por substâncias orgânicas e inorgânicas presentes em despejos industriais tem sido bastante observada, sobretudo no último século, e muitas dessas substâncias são de natureza persistente, como os compostos fenólicos.

Devido à grande toxicidade, os fenóis causam graves problemas ao meio ambiente e à saúde humana e a presença desses compostos em águas residuárias industriais dificulta o processo de tratamento biológico.

Os fenóis estão presentes, nas mais diferentes concentrações, em diversos tipos de águas residuárias industriais, como as das indústrias farmacêuticas e têxteis, de pesticidas, de resinas (fenólicas, epóxicas e poliamidas) e de papel, em efluentes de fundições de metais e de refinarias de petróleo, bem como em águas residuárias de indústrias regionais, como as do beneficiamento da castanha de caju.

A concentração de $0,5 \mathrm{mg} / \mathrm{L}$ de fenóis foi estabelecida como padrão de lançamento para qualquer tipo de efluente, de acordo com a CONAMA (2005), sendo que, no Brasil, em águas destinadas ao abasteciemto, o Ministério da Saúde determinou que o limite máximo permitido de fenol em água destinada ao abastecimento público é de 0,1 $\mu \mathrm{g} / \mathrm{L}$ (MINISTÉRIO DA SAÚDE - PORTARIA 36/GM, 1990) a fim de evitar danos à saúde humana. Em uma portaria mais recente do Ministério da Saúde, Portaria no. 518 (2004), são estipuladas, em águas de abastecimento, concentrações máximas apenas para compostos derivados do fenol, tais como pentaclorofenol $(9 \mu \mathrm{g} / \mathrm{L})$ e 2, 4, 6 triclorofenol $(0,2 \mathrm{mg} / \mathrm{L})$.

Devido à necessidade cada vez maior de preservar os nossos recursos naturais e, consequentemente o homem, buscam-se tecnologias que minimizem os impactos causados pela presença desses composotos no meio. Dentro deste contexto, o uso de fungos em reatores visando o tratamento dos mais diferentes tipos de águas residuárias vem crescendo e despontando como nova tecnologia de biotratamento. Apesar dos poucos trabalhos existentes na área (KOTTERMAN, 1998; RODRIGUES, 1999; Al 
MALAH et al., 2000; SAMPAIO et al., 2004; SANTAELLA et al., 2005), os dados obtidos são bastante promissores quanto à utilização desses microrganismos no tratamento de efluentes, incluindo os que possuem em sua composição substâncias persistentes como fenóis (MARTIRANI et al., 1996; GARCÍA et al., 1997; KOTTERMAN, 1998; GARCÍA et al., 2000).

A potencialidade de se empregar fungos para o tratamento de substâncias persistentes está relacionado à produção de grande número de enzimas extracelulares (proteases, celulases, ligninases, lactases, entre outras) cujas ações tornam os organopoluentes mais acessíveis à biodegradação. Além disso, a capacidade dos fungos de suportar mudanças bruscas na concentração de matéria orgânica, tolerar grandes variações de $\mathrm{pH}$ e de temperatura e se adequar a variações e escassez de umidade e de oxigênio são indicadores da viabilidade do processo de tratamento com reatores fúngicos.

Contudo, pouco ainda se sabe a respeito das atividades metabólicas desses microrganismos quando empregados em processos de tratamento biológico de águas residuárias, o que torna necessário o aprofundamento do estudo dessa nova tecnologia. 


\section{OBJETIVOS}

\subsection{Objetivo Geral}

Este trabalho teve como objetivo principal a avaliação da viabilidade do tratamento de água residuária sintética contendo fenol em reatores biológicos em batelada e contínuos de leito fixo e escoamento ascendente.

\subsection{Objetivos Específicos}

Os objetivos específicos foram:

- Selecionar espécie de fungo adequada para o tratamento da água residuária sintética contendo fenol;

- Verificar a eficiência de remoção de fenol pelo uso reatores com fungos, com e sem adição de glicose na água residuária;

- Determinar parâmetros cinéticos que descrevam o comportamento dos fungos na etapa de batelada;

- Verificar o tempo de detenção hidráulica mais eficiente para a remoção de fenol pelo reator com fungos, de leito fixo e escoamento contínuo;

- Comparar a eficiência de dois reatores contínuos com meios suportes distintos, manta agulhada de polipropileno e espuma de poliuretano, operando sob as mesmas condições. 


\section{REVISÃO BIBLIOGRÁFICA}

\section{1 Águas Residuárias Contendo Compostos Fenólicos e Processos de Tratamento}

O fenol, caracterizado por uma hidroxila diretamente ligada a um anel benzênico, conforme mostrado na Figura 3.1, foi descoberto em 1834, como um composto derivado do alcatrão, primeiramente empregado sob a forma de creosoto para prevenir o desgaste natural de ferrovias e de cascos de navios e utilizado em esgotos domésticos com o objetivo de diminuir o odor gerado pela decomposição desses despejos (van SCHIE e YOUNG, 2000). É um composto pouco solúvel em água e com cheiro forte característico, tóxico e de ação cáustica sobre a pele (HOLUM, 1994). Na Tabela 3.1 são mostradas algumas propriedades físicas do fenol, também conhecido como ácido carbólico, ácido fênico, ácido fenílico, hidróxido fenil, hidroxibenzeno e oxibenzeno (THE MERCK INDEX, 1996).

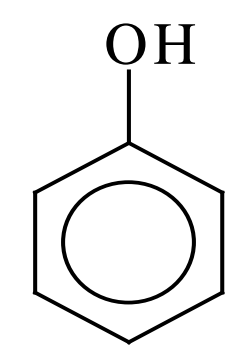

Figura 3.1: Fórmula estrutural do fenol 
Os compostos fenólicos são encontrados na natureza como resultado da decomposição de substâncias húmicas, ligninas e taninos, contudo, em concentrações bem menores que as geradas pelas atividades antrópicas (TIMUR et al., 2004). São encontrados em sistemas marinhos, sendo produzidos por algas, plantas e invertebrados, e nas fezes e urina de animais, incluindo o homem (van SCHIE e YOUNG, 2000).

Tabela 3.1: Propriedades físicas do fenol

\begin{tabular}{cc}
\hline & Propriedades \\
\hline Fórmula molecular & $\mathrm{C}_{6} \mathrm{H}_{6} \mathrm{O}$ \\
Massa molecular & 94,11 \\
Ponto de fusão & $43^{\circ} \mathrm{C}$ \\
Ponto de ebulição & $182^{\circ} \mathrm{C}$ \\
Densidade & $1071 \mathrm{~g} / \mathrm{cm}^{3}$ \\
\hline
\end{tabular}

FONTE: THE MERCK INDEX (1996)

Pode-se obter o fenol naturalmente, através da destilação do alcatrão, ou por processos sintéticos, como a oxidação do cumeno (metiletilbenzeno), tolueno, fusão de benzeno sulfonato de sódio com hidróxido de sódio ou por aquecimento de monoclorobenzeno com hidróxido de sódio, sob condições de alta pressão (van SCHIE e YOUNG, 2000). Ainda, segundo esses autores, cerca de $70 \%$ do fenol produzido industrialmente é empregado na fabricação de resinas, mas o composto é também utilizado em explosivos, tintas, perfumes, conservantes de madeira (pentaclorofenol), têxteis, desinfetantes bactericidas, fungicidas e anestésico.

Os compostos fenólicos podem ser altamente tóxicos, carcinogênicos e alergogênicos e, devido a esses efeitos, sua determinação e remoção do ambiente é de grande importância (TIMUR et al., 2004).

De acordo com Santos e Linardi (2004), muitos compostos tóxicos são formados durante processos industriais, o que se confirma com a variedade de componentes encontrados nessas águas residuárias. Os compostos fenólicos são, entre os resíduos orgânicos, os de maior potencial poluidor, em virtude de suas características ácidas, tóxicas e bactericidas. Portanto, exigem tratamento antes de seu lançamento em corpos receptores (BOLAÑOS et al., 2001). 
Vários processos físico-químicos, como: osmose reversa, ultrafiltração e oxidação química têm sido empregados no tratamento de efluentes contendo fenol. Contudo, esses métodos requerem investimentos e manutenção de custo elevado (D’ANNIABALE et al., 1998). Além disso, seus efluentes freqüentemente exigem tratamento secundário devido à presença de altos níveis de matéria orgânica remanescente (CHANG et al., 1995). Por outro lado, os processos biológicos possuem custos relativamente baixos (KOTSOU et al., 2004), em comparação com os processos físico-químicos, e apresentam menor efeito adverso sobre o ambiente (METCALF e EDDY , 1991; KAUFFMAN et al., 1999).

De acordo com Santos e Linardi (2004), embora o metabolismo microbiano de compostos aromáticos tenha sido intensivamente estudado, a maior parte do conhecimento sobre rotas metabólicas da degradação desses compostos encontra-se fundamentada em bactérias. No entanto, estudos têm mostrado que fungos atuam como decompositores importantes de compostos aromáticos na biosfera, entre eles, os fenóis (SANTOS e LINARDI, 2004).

Tanto bactérias quanto fungos têm desenvolvido mecanismos de sobrevivência em concentrações consideradas tóxicas (van SHIE e YOUNG, 2000), ainda que Koutsou et al. (2004) relatem que a degradação biológica pode ser inibida pela presença de compostos aromáticos, fenólicos e polifenólicos em concentrações elevadas, o que varia de uma espécie para outra. Verifica-se, também, que a imobilização de células microbianas em meios suportes ajuda a proteger os microrganismos contra as substâncias tóxicas (PRIETO et al., 2002).

\subsection{Principais Características e Fisiologia dos Fungos}

As explorações dos fungos pelo homem não são recentes e seus usos para a produção de produtos comerciais aumentaram rapidamente desde a metade do século passado (PAPAGIANNI, 2004).

Os fungos são amplamente utilizados nas produções de antibióticos, enzimas e produtos alimentícios (PRICE et al., 2001). São também empregados em processos de biorremediação, por serem decompositores primários importantes nos ciclos do 
carbono, nitrogênio e outros nutrientes da biosfera e na deterioração de diversos materiais (GRIFFIN, 1994). Os fungos apresentam capacidade de degradar grande variedade de poluentes, sob condições limitantes, e crescem em meios ácidos (GARCÍA-PEÑA et al., 2001).

Os microrganismos fúngicos são componentes significantes da microflora do solo. Vivem também nos vegetais e na água, espalhando-se amplamente pela natureza, em decorrência da produção de elementos de disseminação - os propágulos, sendo o ar atmosférico uma das vias de disseminação. Os fungos dispersos pelo ar são chamados de anemófilos. As ocorrências mais freqüentes nas regiões do Brasil pertencem aos gêneros Cladosporium, Penicillium, Aspergillus, Curvularia, Rhodotorula, Candida, Aureobasidium, Fusarium, Helmithosporium e Trichoderma (BITTON, 1994; TRABULSI, 1999).

Os fungos são microrganismos eucarióticos e heterotróficos que podem ser unicelulares (leveduras) ou pluricelulares (fungos filamentosos ou bolores). Os filamentos fúngicos são denominados hifas e o seu conjunto constitui o micélio fúngico. As hifas são estruturas tubulares que são originadas a partir de um único esporo reprodutivo (PAPAGIANNI, 2004) e podem ser simples ou ramificadas e se dividir em compartimentos celulares por meio de septos (LACAZ et al., 1998).

Os fungos filamentosos são morfologicamente complexos e podem exibir formas diferentes. O crescimento de fungos filamentosos pode ocorrer na forma de "pellets", com as hifas formando pequenas esferas, ou na forma filamentosa, com as hifas dispersas no meio, dependendo de vários fatores, como: espécie do fungo, meio de cultura, agitação, pH, oxigênio dissolvido e o quanto de inóculo foi utilizado (concentração de esporos, massa de micélio) (PAMBOUKIAN, 1997).

Sabe-se muito pouco sobre os mecanismos de alongamento, ramificação e fragmentação das hifas, porém a forma de crescimento e o número de células viáveis no meio de cultura está relacionada com os metabólitos primários e secundários produzidos pelos microrganismos (PINTO et al., 2004).

Concentração celular elevada e crescimento filamentoso (hifas dispersas) aumentam a viscosidade do líquido. A morfologia influencia diretamente a reologia do meio de cultura, por outro lado, as características do meio também interferem na fisiologia e morfologia dos microrganismos, constituindo-se em uma relação complexa, 
o que torna o controle das variáveis morfológicas uma tarefa difícil (PINTO et al., 2004).

Segundo Pamboukian (1997), gêneros como Aspergillus e Penicillium podem crescer sob a forma de "pellets", porém isto não ocorre com todos os fungos. A formação de "pellets" no gênero Aspergillus ocorre devido à agregação de esporos no início da germinação, processo que, para ocorrer, exige a presença de nutrientes, como carbono, nitrogênio e oxigênio, e condições físicas adequadas (temperatura e umidade). Na germinação, há o aumento do volume dos esporos, que são o início e o final de vida do fungo filamentoso, um estado de latência do microrganismo, quando não ocorre síntese de material celular e a atividade metabólica é reduzida (NIELSEN, 1992).

De modo geral, o ideal para crescimento dos fungos é que o meio tenha $\mathrm{pH}$ de $4 \mathrm{a}$ 6. Contudo, dependendo da espécie em questão, essa faixa ótima de $\mathrm{pH}$ pode assumir valores mais específicos, pois os fungos, devido à retirada diferenciada de cátions e ânions durante o transporte de substrato, freqüentemente alteram o $\mathrm{pH}$ do meio onde se encontram (GRIFFIN, 1994).

Os compostos orgânicos são utilizados pelos fungos como fontes de carbono e de energia, sendo seu crescimento ótimo em meios ácidos ( $\mathrm{pH}$ em torno de 5). A maioria das espécies fúngicas é aeróbia, entretanto algumas podem crescer em condições anaeróbias facultativas (BITTON, 1994).

Como são seres aclorofilados, os fungos necessitam de substâncias orgânicas que não conseguem sintetizar, absorvendo-as do meio através da produção de enzimas extracelulares e intra-celulares que hidrolisam macromoléculas, as quais se tornam assimiláveis por mecanismos de transporte. Por essa razão, os fungos são obrigados a viver em estado de saprofitismo, parasitismo ou em simbiose (TRABULSI, 1999).

A obtenção de energia pelos fungos pode ocorrer através de via oxidativa (respiração) ou por fermentação. Na respiração, o oxigênio é o principal oxidante, contudo, sob condições de baixas concentrações de oxigênio, algumas espécies podem fazer uso de nitrato como oxidante. O processo de respiração resulta na conversão completa de compostos orgânicos a dióxido de carbono e água, com energia gerada por fosforilação oxidativa (CARLILE e WATKINSON, 1994). Os organismos capazes de obter energia por ambas as vias (respiração e fermentação), conseguem crescer sob condições aeróbias e anaeróbias (CARLILE e WATKINSON, 1994). 
No processo de respiração, ocorre oxidação de glicose para obtenção de energia. A glicose é, quantitativamente, o principal substrato oxidável para a maioria dos organismos, sendo seu uso universal para obtenção de energia pela célula (MARZZOCO e TORRES, 1999). De acordo com Costa et al. (2004), a glicose é um suprimento de carbono essencial para produção de proteínas, polissacarídeos e lipídios. As vias glicolíticas presentes em fungos favorecem a conversão de glicose a piruvato, de modo a gerar energia, percussores e componentes para síntese e reações de oxidação ou redução para conversão desses em produtos intermediários e finais (AINSWORTH e SUSSMAN, 1966).

Carboidratos simples como glicose são inicialmente preferidos pelos fungos, mas outras fontes podem ser utilizadas, tais como sacarose, maltose, amido, celulose, etc (TRABULSI, 1999).

Na fermentação, o piruvato produzido é utilizado como aceptor de elétrons, sendo o exemplo mais clássico a fermentação do piruvato a etanol e $\mathrm{CO}_{2}$ por Sacharomyces cerevisiae (GRIFFIN, 1994).

As substâncias nitrogenadas inorgânicas (sais de amônio ou nitrato) ou orgânicas (peptonas) são necessárias aos fungos, assim como sulfatos e fosfatos (TRABULSI, 1999).

De acordo com Griffin (1994), as exigências nutricionais dos fungos podem ser divididas em duas categorias: micronutrientes (concentrações iguais ou menores que $10^{-6} \mathrm{~mol} / \mathrm{L}$ ) e macronutrientes (concentrações em torno de $10^{-3} \mathrm{~mol} / \mathrm{L}$ ). Entre os macronutrientes - carbono, hidrogênio, oxigênio, fósforo, potássio, nitrogênio, enxofre e magnésio - o carbono é o elemento principal em combinação com hidrogênio, oxigênio e nitrogênio. Na Tabela 3.2 é mostrada a função de alguns macronutrientes no metabolismo fúngico.

O nitrogênio pode ser suprido no meio como amônia, nitrato ou compostos orgânicos (aminoácidos ou proteínas) (PAPAGIANNI, 2004), sendo a amônia a forma prontamente assimilada pelos fungos. Contudo, nitrato encontra-se em maior disponibilidade no solo e é amplamente utilizado, embora muitos fungos Oomycetos e Basidiomicetos não sejam capazes de assimilá-lo (GRIFFIN, 1994). 
Tabela 3.2: Macronutrientes e sua função no metabolismo fúngico.

\begin{tabular}{ccc}
\hline Elemento & Fonte & Função \\
\hline Enxofre & $\mathrm{K}_{2} \mathrm{SO}_{4}$ & $\begin{array}{c}\text { Síntese de aminoácidos } \\
\text { Vitaminas }\end{array}$ \\
Fósforo & $\mathrm{KH}_{2} \mathrm{PO}_{4}$ & $\begin{array}{c}\text { Ácidos nucléicos } \\
\text { Transferência de energia } \\
\end{array}$ \\
& & Metabolismo intermediário \\
Nitrogênio & $\mathrm{NaNO}_{3}, \mathrm{NH}_{4} \mathrm{Cl}$ & $\begin{array}{c}\text { Aminoácidos } \\
\text { Nucleotídeos } \\
\text { Magnésio }\end{array}$ \\
& & Vitaminas \\
& $\mathrm{MgCl}_{2}$ & Atividade enzimática \\
Potássio & $\mathrm{KCl}, \mathrm{K}_{2} \mathrm{HPO}_{4}$ & Síntese de ácidos nucléicos \\
& & Atividade enzimática \\
& & Metabolismo de carbohidratos \\
\hline
\end{tabular}

Fonte: adaptado de Griffin (1994)

Ainda, de acordo com Griffin (1994), a assimilação de nitrato é mediada pela ação das enzimas nitrato redutase e nitritro redutase, responsáveis, respectivamente, pela conversão de nitrato a nitrito e de nitrito a amônia.

O gênero Aspergillus pertence ao grupo de fungos filamentosos de grande interesse industrial devido à produção de enzimas como as glucanases, muito utilizadas em processos como fabricação de pães, sucos e outros alimentos, na indústria têxtil, entre outras.

A espécie Aspergillus niger possui extrema importância na indústria de fermentação para a produção de ácido cítrico, utilizado na conservação de bebidas (O’DONNEL et al., 2001). De acordo com Carlile e Watkinson (1994), a faixa inicial de pH para a germinação dessa espécie é de 5 a 7, sendo que, devido à produção e acúmulo de ácidos orgânicos como o cítrico, o $\mathrm{pH}$ pode chegar a 2, inibindo naturalmente a ocorrência de outros microrganismos.

Segundo Sangtiean e Schimidt (2002), fungos utilizam amônia e nitrato em velocidades diferentes. A espécie Aspergillus niger é capaz de utilizar simultaneamente nitrato e amônia, embora a velocidade de consumo de nitrogênio amoniacal seja superior à de nitrato (AINSWORTH e SUSSMAN, 1966). Ainda, segundo Ainsworth e 
Sussman (1966), a velocidade de consumo de amônia tende a ser maior em meios alcalinos.

Sangtiean e Schimidt (2002) verificaram que o uso de nitrato como única fonte de nitrogênio resulta em atividade redutora de nitrato similar àquela em que se emprega no meio contendo nitrato e amônia.

De acordo com Carlile e Watkinson (1994), o balanço entre a fonte de carbono e de nitrogênio do meio deve ser observado, sendo essencial em processos industriais com aplicação dos fungos.

É importante ressaltar que o catabolismo das fontes de nitrogênio encontra-se associado ao anabolismo das fontes de carbono (COSTA et al., 2004). Hwang et al. (2004) empregaram Aspergillus niger como inóculo de reator de escoamento contínuo e de leito em placas ("fixed-slab reactor") para o tratamento de água residuária contendo nitrito, amônia, proteína e glicose. Esses autores estudaram o consumo de carbono e nitrogênio pela espécie Aspergillus niger e constataram que a elevação da temperatura (de 25 para $35^{\circ} \mathrm{C}$ ) aumentava a velocidade de consumo da fonte de carbono e diminuía a velocidade de consumo de nitrogênio. Também foi verificado uso simultâneo de amônia, nitrito e proteína presentes na água residuária pela referida espécie.

O fósforo pode ser suprido sob a forma de fosfato, sendo dipotássio hidrogeno de fosfato $\left(\mathrm{K}_{2} \mathrm{HPO}_{4}\right)$ o sal mais empregado. $\mathrm{O}$ fosfato entra na célula através de transporte ativo como íon $\mathrm{H}_{2} \mathrm{PO}_{4}{ }^{-}$(CARLILE e WATKINSON, 1994). O enxofre é geralmente fornecido ao meio como sulfato, pois quase todos os fungos são capazes de assimilá-lo nessa forma (GRIFFIN, 1994). O enxofre é utilizado pela maioria dos fungos como sulfato, que entra na célula através de transporte ativo, sendo convertido a adenosina fosfossulfato (CARLILE e WATKINSON, 1994).

Entre os micronutrientes, ferro, cobre, zinco, manganês e molibdênio são os mais requeridos pelos fungos. Na Tabela 3.3, são indicadas as fontes e a função respectiva dos nutrientes no metabolismo fúngico (GRIFFIN, 1994).

Elementos como: ferro, cobre, manganês, zinco e molibdênio são exigidos por todos ou quase todos os organismos, como co-fatores de enzimas. Entretanto, estes elementos podem ser tóxicos em concentrações superiores às requeridas para o crescimento $\left(10^{-6}\right.$ a $\left.10^{-9} \mathrm{M}\right)$ (CARLILE e WATKINSON, 1994). 
Tabela 3.3: Micronutrientes e sua função no metabolismo fúngico.

\begin{tabular}{|c|c|c|}
\hline Elemento & Fonte & Função \\
\hline Cobre & $\mathrm{CuSO}_{4}$ & Atividade enzimática \\
\hline Ferro & $\begin{array}{l}\mathrm{FeCl}_{3} \\
\mathrm{FeSO}_{4}\end{array}$ & $\begin{array}{l}\text { Citocromos } \\
\text { Apoenzimas }\end{array}$ \\
\hline Manganês & $\mathrm{MnCl}_{2}$ & $\begin{array}{l}\text { Atividade enzimática } \\
\text { Síntese de ácidos nucléicos }\end{array}$ \\
\hline Molibdênio & $\mathrm{Na}_{2} \mathrm{MoO}_{4}$ & $\begin{array}{l}\text { Atividade enzimática } \\
\text { Metabolismo do nitrato }\end{array}$ \\
\hline Zinco & $\mathrm{ZnCl}_{2}$ & $\begin{array}{l}\text { Atividade enzimática e metabolismo de ácidos } \\
\text { orgânicos e outros intermediários }\end{array}$ \\
\hline
\end{tabular}

Fonte: adaptado de Griffin (1994)

De acordo com Ainsworth e Sussman (1966), não apenas o molibdênio encontrase envolvido na atividade redutora de nitrato. Os sais de ferro, de cobre e de manganês também participam desse mecanismo e atuam nas etapas de conversão de nitrito a amônia.

Além da presença de macro e micronutrientes, os aspectos físicos, tais como temperatura, luz, viscosidade e pressão hidrostática podem afetar o crescimento dos fungos. A umidade possui papel importante na germinação dos esporos, sendo que sua escassez pode limitar a esporulação. A luminosidade exerce maior influência sobre a reprodução que no crescimento dos fungos, contudo, a maior parte dos estudos está voltada para a temperatura (GRIFFIN, 1994).

Desse modo, os fungos podem ser classificados em função da temperatura em psicrófilos, mesófilos e termófilos. Os fungos psicrófilos não crescem em temperaturas superiores a $20^{\circ} \mathrm{C}$, sendo a faixa ótima de temperatura de $0^{\circ} \mathrm{C}$ a $17^{\circ} \mathrm{C}$; os mesófilos crescem à temperatura mínima acima de $0^{\circ} \mathrm{C}$ e máxima abaixo de $50^{\circ} \mathrm{C}$ e os fungos termófilos são aqueles que crescem a temperaturas mínimas em torno de $20^{\circ} \mathrm{C}$ e máximas a cima de $50^{\circ} \mathrm{C}$ (GRIFFIN, 1994).

A temperatura exerce influência sobre os metabolismos primário e secundário de várias maneiras, ocorrendo aumento das exigências nutricionais a temperaturas mais elevadas (CARLILE e WATKINSON, 1994). 
Em relação ao crescimento dos fungos, em culturas no regime de batelada, podem ocorrer mudanças no $\mathrm{pH}$ do meio e na disponibilidade de oxigênio e de fatores nutricionais, que interferem diretamente na duração das diferentes fases do crescimento do microrganismo (fase lag, exponencial, estacionária e autólise ou fase endógena). No regime contínuo, se o suprimento de nutrientes for mantido constante, ocorrerá manutenção de crescimento exponencial e descarte de produtos excretados, bem como de biomassa morta (GRIFFIN, 1994).

Dentre os compostos produzidos pelos fungos durante o seu crescimento, a partir do consumo do substrato, citam-se álcoois e ácidos orgânicos. O gênero Aspergillus é conhecido por sua capacidade de produzir ácidos orgânicos como o cítrico, málico, fumárico, glucônico, entre outros (WITTEVEEN, 1993; GRIFFIN, 1994).

A produção significativa de ácidos orgânicos pelos fungos depende das condições do meio, as quais variam dependendo ácido envolvido. As principais variáveis que exercem influência sobre a produção dos ácidos orgânicos são o pH do meio, aeração adequada e presença de uma fonte de carbono de assimilação rápida que deve estar presente em concentração elevada. Além destas variáveis, também influenciam a produção de ácidos orgânicos: os níveis de fosfato e nitrato e a presença de metais traço (WITTEVEEN, 1993).

O transporte dos ácidos orgânicos pela membrana celular se dá por difusão ou através de sistema específico, como o que envolve o ciclo do ácido tricarboxílico e piruvato. Contudo, a difusão é o mecanismo mais simples e rápido, ocorrendo a partir da não dissociação do ácido. Se o pH estiver uma unidade acima do pK, o ácido fica na

forma dissociada e o transporte do ácido e dos ânions orgânicos será mais lento, mas se o pH estiver abaixo do pK, então, a forma não dissociada é transportada mais rapidamente e o metabolismo é mais rápido (AINSWORTH e SUSSMAN, 1966).

\subsection{Crescimento de biofilmes de fungos em meios suportes}

Os biofilmes são constituídos por microrganismos envolvidos por uma matriz de substâncias poliméricas extracelulares, altamente hidratadas, com $85 \%$ a $98 \%$ de água (WALLSTÖM et al., 2002). 
$\mathrm{Na}$ natureza, a formação de biofilmes por fungos é um processo complexo que tem início com a adesão de esporos a uma superfície, influenciada por fatores físicos, químicos e ambientais. Tanto os microrganismos como as superfícies possuem potenciais negativos, gerando repulsão eletrostática. Porém, a presença de proteínas hidrofóbicas (hidrofobinas) no esporo provoca sua aderência à superfícies para iniciar a germinação. As hidrofobinas são produzidas por várias espécies de ascomicetos, basidiomicetos e zigomicetos e, além da adesão dos esporos, desempenham funções no crescimento e desenvolvimento do fungo, como, por exemplo, na formação de suas estruturas aéreas: micélio e corpos frutíferos (VILLENA e GUTIÉRREZ-CORREA, 2003).

As bactérias e os fungos são micorganismos dominantes em reatores biológicos e a maioria dos biofilmes possui quantidade substancial de ambos. Embora os fungos apresentem crescimento mais lento em relação às bactérias (GARCÍA-PEÑA et al., 2001), possuem a vantagem de se ramificarem rapidamente no meio onde se encontram e, através das enzimas secretadas, são capazes de tolerar maiores concentrações de substâncias tóxicas (WALLSTRÖM et al., 2002).

A ramificação do micélio ajuda os fungos filamentosos, especialmente na colonização de substratos sólidos, pois a penetração da hifa pode levar a um mecanismo complementar na quebra da ligação química do composto e propiciar maior contato enzimático com o substrato, devido à elevada relação superfície:célula (WALLSTRÖM et al., 2002). Em superfícies porosas, ocorre penetração da hifa dentro dos poros, ligando o microrganismo ao meio suporte (PETRE et al., 1999).

A imobilização de células é importante em vários processos biológicos, como no tratamento de águas residuárias e é um estado natural para os microrganismos; a maioria dos fungos que tende a aderir firmemente às superfícies (COUTO et al., 2004).

A imobilização de microrganismos em meios suportes é uma técnica que tem por objetivo limitar a migração de células livres, podendo ocorrer por uma adesão artificial (induzida), ou natural (auto-imobilização). Na adesão artificial ou induzida, os microrganismos são fixados nos interstícios de um material fibroso ou poroso com a ajuda de um gel ou membrana, ou seja, os microrganismos são retidos fisicamente (COUTO et al., 2004) 
Declerck et al. (1996) utilizaram a técnica artificial para imibolização de esporos de Glomus vesiforme em alginato. Os esporos foram adicionados em solução de alginato de sódio (20 g/L) e, em seguida, removidos, com ajuda de microscópio e micropipeta, e colocados em solução esterilizada de cloreto de cálcio $(0,1 \mathrm{M})$, na qual foram agitados por 10 min. Foram obtidos quatro tipos de inóculo, consistindo de um, dois, três ou quatro esporos encapsulados pelo alginato. A principal desvantagem dessa técnica é a impossibilidade de imobilização de todas as células viáveis do microrganismo, pois é um procedimento que depende de fatores como a composição da parede celular, a idade da célula e a especificidade morfo-genética do microrganismo, bem como das propriedades físico-químicas da matriz de imobilização, como, por exemplo, a porosidade do material, o pH e as condições nutricionais do meio (PETRE et al, 1999).

A imobilização natural é caracterizada pela aderência do microrganismo à superfícies ou a outros organismos por ligação química (COUTO et al., 2004). A capacidade de secretar polissacarídeos com propriedades adesivas permite que os fungos sejam capazes de aderir firmemente aos meios suportes (PETRE et al., 1999). Segundo esses autores, fungos filamentosos apresentam grande afinidade por superfícies inorgânicas e orgânicas, porém os mecanismos de aderência ainda não se encontram esclarecidos.

De acordo com Arica et al. (2001), os meios suportes mais utilizados para imobilização pela técnica artificial são polímeros naturais como alginato, quitosina, quitina e celulose. $\mathrm{Na}$ imobilização natural, os materiais mais freqüentemente empregados são espumas sintéticas de poliuretano e de naylon (COUTO et al., 2004), além de mantas geotêxteis de poliamida e telas de poliéster (VILLENA e GUTIÉRREZCORREA, 2003; SAMPAIO, 2005).

Na Tabela 3.4 são apresentadas espécies fúngicas imobilizadas em diferentes meios suportes pela imobilização natural.

Kim e Shoda (1999) imobilizaram Geotichum candidum em matrizes de poliuretano para remoção de cor de água residuária do melaço, caracterizada pela presença de compostos polimerizados e coloridos complexos, em concentrações entre 40000 a 50000 mg DQO/L. Para a imobilização das células, foi utilizado um reator de 0,7 L, operado em regime de batelada, com $600 \mathrm{~mL}$ da água residuária, $200 \mathrm{~mL}$ de espuma de poliuretano (cubos de aresta de $5 \mathrm{~mm}$ ) e $15 \mathrm{~mL}$ de suspensão de esporos. $\mathrm{O}$ oxigênio foi fornecido ao meio na vazão de $0,5 \mathrm{~L} / \mathrm{min}$. Quando a remoção de cor atingiu 
$80 \%$, o sobrenadante foi descartado e substituído por $550 \mathrm{~mL}$ de água residuária fresca, promovendo-se a mistura para homogeneização do meio, de modo que o procedimento de imobilização durou cerca de 10 dias, após o qual o reator foi operado no regime de batelada alimentada por mais 32 dias.

Tabela 3.4: Imobilização natural ou auto-imobilização de espécies fúngicas em meios suportes.

\begin{tabular}{ccc}
\hline Pesquisador & Fungo & Meio Suporte \\
\hline Kim e Shoda (1999) & $\begin{array}{c}\text { Geotrichum } \\
\text { candidum }\end{array}$ & $\begin{array}{c}\text { Espuma de } \\
\text { poliuretano }\end{array}$ \\
Sankapal e Kulkarni (2002) & $\begin{array}{c}\text { Aspergillus } \\
\text { niger }\end{array}$ & Tela de celulose \\
Villena e Gitiérrez-Correa (2003) & $\begin{array}{c}\text { Aspergillus } \\
\text { niger }\end{array}$ & Tela de poliéster \\
& $\begin{array}{c}\text { Aspergillus } \\
\text { niger }\end{array}$ & $\begin{array}{c}\text { Espuma de } \\
\text { poliuretano }\end{array}$ \\
\hline
\end{tabular}

Sankapal e Kulkarni (2002) empregaram células imobilizadas de Aspergillus niger NCIM em reator para produção de ácido glucônico. O meio suporte foi tela de celulose $\left(68 \times 8,5 \times 0,6 \mathrm{~cm}^{3}\right)$. O processo de imobilização durou 6 dias e o meio de crescimento possuía em sua composição, glicose (100 g/L), $\mathrm{MgSO}_{4} \cdot 7 \mathrm{H}_{2} \mathrm{O}(0,25 \mathrm{~g} / \mathrm{L}), \mathrm{KH}_{2} \mathrm{PO}_{4}(0,30$ $\mathrm{g} / \mathrm{L})$ e $\left(\mathrm{NH}_{4}\right)_{2} \mathrm{HPO}_{4}(0,80 \mathrm{~g} / \mathrm{L})$, com o pH ajustado em 6 com $\mathrm{H}_{2} \mathrm{SO}_{4}(1 \mathrm{M})$.

Villena e Gitiérrez-Correa (2003) imobilizaram Aspergillus niger em tela de poliéster, cortada em quadrados de $2 \mathrm{~cm}$ de lado, utilizando uma suspensão de $10^{6}$ esporos/mL que foi adicionada, juntamente o meio suporte, em $30 \mathrm{~mL}$ do meio de crescimento descrito por Duff (1998) ${ }^{1}$ apud Villena e Gitiérrez-Correa (2003). O cultivo ocorreu sob agitação de $175 \mathrm{rpm}$, a $28^{\circ} \mathrm{C}$, durante 5 dias, sendo depois lavadas com

\footnotetext{
${ }^{1}$ DUFF, J. (1998). Use of surface-immobilized Trichoderma in batch and fed-batch fermentation. Biothecnology and Bioengineering apud VILLENA, G. K., GUTIÉRREZ-CORREA, M.

(2003). Biopelículas de Aspergillus niger para la production de celulasas. Rev. Peru. Biol. 10: 78 - 87.
} 
tampão de citrato $(50 \mathrm{mM})$, para remoção de esporos não aderidos, e transferidos para reator com o objetivo de produzir celulase.

Esporos de Aspergillus niger foram imobilizados por Mukhopadhyay et al. (2005) em cubos de espuma de poliuretano ( $1 \mathrm{~g})$, previamente lavados e submersos em frascos de $250 \mathrm{~mL}$, com $50 \mathrm{~mL}$ de meio esporulante que possuía: glicose (5\%), lactose (5\%), $\left(\mathrm{NH}_{4}\right)_{2} \mathrm{HPO}_{4}(0,05 \%), \mathrm{KH}_{2} \mathrm{PO}_{4}(0,06 \%)$ e $\mathrm{MgSO}_{4} \cdot 7 \mathrm{H}_{2} \mathrm{O}(0,015 \%)$. A esse meio, foi adicionado $0,5 \mathrm{~mL}$ da suspensão de esporos, na concentração de $5,5 \times 10^{7}$ esporos $/ \mathrm{mL}$. Os frascos foram mantidos por 3 dias, sob agitação $(250 \mathrm{rpm})$, e, após este período, os cubos foram separados do meio, lavados com água destilada estéril e usados em reator para produção de ácido glucônico.

A imobilização de fungos em meios suportes também pode ser realizada com micélio. Raghukumar et al. (2004) utilizaram micélio de Flavodon flavus para imobilização em cubos de espuma de poliuretano. Os cubos $\left(1 \mathrm{~cm}^{2}\right)$ foram colocados em um recipiente com água, onde ficaram até a ebulição do líquido, sendo depois lavados com água destilada e submetidos a $121^{\circ} \mathrm{C}$, em autoclave. Os cubos foram embebidos em meio com baixa concentração de nitrogênio $(2 \mathrm{nM})$, que possuía como base uma água residuária com melaço, diluída até a concentração desejada de nitrogênio, e inoculados com o micélio macerado de Flavodon flavus, previamente cultivado no referido meio. Após 7 dias, os cubos apresentaram-se cobertos pelo micélio do fungo, formando o biofilme. $\mathrm{O}$ excesso do meio foi removido e os cubos foram lavados com a água residuária, diluída a 10\%, para posterior utilização em experimento.

\subsection{Mecanismos de remoção de poluentes por fungos}

A remoção de poluentes de um meio por fungos ocorre pelo processo conhecido como biossorção, dividido em duas fases distintas: adsorção (remoção passiva) e assimilação (remoção ativa).

De acordo com Del Rio (2004), a adsorção é a primeira etapa do processo de biossorção e não depende da atividade metabólica do microrganismo. A assimilação, ao contrário, é dependente do metabolismo. 
A compreensão do processo de biossorção é importante no tratamento de efluentes líquidos e também em vários processos industriais como panificação, cervejarias e destilarias (DEL RIO, 2004).

No tratamento de águas residuárias tem sido estudada a remoção de poluentes a partir do uso de biomassa viva ou morta. O uso de biomassa morta elimina problemas de toxicidade e a adição de nutrientes para manutenção dos microrganismos, envolvendo forças de adsorção químicas e físicas, independente do metabolismo (SEKHAR et al., 1998). Por outro lado, neste caso, como o poluente fica apenas adsorvido ao micélio do fungo, não ocorrendo sua assimilação e transformação em material celular, pode não haver uma solução real do problema, a não ser que o poluente envolvido possa ser recuperado e posteriormente reutilizado para fins específicos.

Estudos sobre o potencial da biomassa fúngica como biossorvente envolvem, principalmente, a remoção de metais (cádmio, cromo, cobre, zinco e urânio), através do mecanismo de adsorção (KAPOOR et al., 1999; RAO e VIRARAGHAVAN, 2002).

A adsorção de fenol pelo micélio pode ocorrer, embora pesquisas tenham demonstrado que o potencial de adsorção é maior em células mortas, quando os fungos são empregados como biossorventes (RAO e VARARAGHAVAN, 2002). Goyal et al. (2003) relataram que, em células vivas, a adsorção ocorre mais rápido que a assimilação, sob grande influência do pH (RAO e VIRARAGHAVA, 2002; GOYAL et al., 2003).

Rao e Viraraghavan (2002) estudaram a influência do pH na biossorção de fenol utilizando biomassa morta de Aspergillus niger em solução aquosa. $\mathrm{O}$ experimento, com frascos de $125 \mathrm{~mL}$ em batelada, foi realizado com temperatura controlada $\left(21^{\circ} \mathrm{C}\right) \mathrm{e}$ agitação de $125 \mathrm{rpm}$. Foram utilizados $200 \mathrm{mg}$ de biomassa em pó de A. niger, prétratada com ácido sulfúrico e $75 \mathrm{~mL}$ de solução de fenol, na concentração de $1000 \mu \mathrm{g} / \mathrm{L}$. $\mathrm{O}$ pH 5,1 foi o melhor e o aumento ou diminuição a partir desse valor resultou na redução da biossorção do poluente pela biomassa fúngica. Não houve biossorção do fenol em $\mathrm{pH}$ superior a 10 .

De acordo com Huang et al. (1988), a biomassa dos fungos possui carga superficial negativa em valores de $\mathrm{pH}$ entre 3 e 10 . O pré-tratamento com ácido sulfúrico gera locais positivamente carregados na superfície da célula, devido ao excesso de íons $\mathrm{H}^{+}$. O fenol é um ácido fraco, parcialmente ionizado na solução, de 
modo que os íons negativamente carregados são atraídos à biomassa, com carga superficial positiva, por forças eletrostáticas.

Contudo, a maior parte das pesquisas sobre remoção de compostos orgânicos tóxicos (fenol, lindano, dieldrin, entre outros) ocorre com emprego de células vivas, quando o mecanismo principal de remoção é o de assimilação (KAPOOR et al., 1999; RAO e VIRARAGHAVAN, 2002).

A assimilação de compostos ocorre por meio de reações em cadeia. Os fungos produzem diversos compostos por intermédio dessas reações, sendo cada reação catalisada por enzimas específica elaborada, normalmente, no interior da célula. Essas enzimas obedecem a processos controlados para formação de produtos que podem ser utilizados total ou parcialmente pelo microrganismo (AINSWORTH e SUSSMAN, 1966).

Com relação à degradação de fenol, de acordo com Ainsworth e Sussman (1966), os fungos são capazes de adicionar e remover hidroxilas de compostos aromáticos e grande número de arranjos pode ser formado.

De acordo com Harrison et al. (2001), a degradação aeróbia do fenol é realizada pela via catecol. Os fungos e as bactérias aeróbias, geralmente, metabolizam o fenol na forma de catecol (WRIGHT, 1993), chave da metabolização de vários compostos aromáticos pelos microrganismos, pois a partir dele ocorre a quebra do anel aromático para futura assimilação.

Sob condições aeróbias, a presença de oxigênio no meio é necessária para preparar o fenol para a fissão do anel, usando enzimas para catalisar a incorporação de um ou dois átomos de oxigênio para formar ortho - catecol ou para - catecol, compostos dihidróxi e, como resultado do metabolismo, são formados ácidos (BESLE et al, 1995).

Segundo van Schie e Young (2000), os mecanismos de biodegradação aeróbia do fenol envolvem a participação de enzimas específicas (fenol hidroxilases) e, dependendo do microrganismo envolvido, podem resultar em ácido mucônico (via orto dirigente) e no semialdeído hidroximucônico (via meta dirigente), os quais entram no ciclo de Krebs e geram novos produtos, como apresentado na Figura 3.2. 


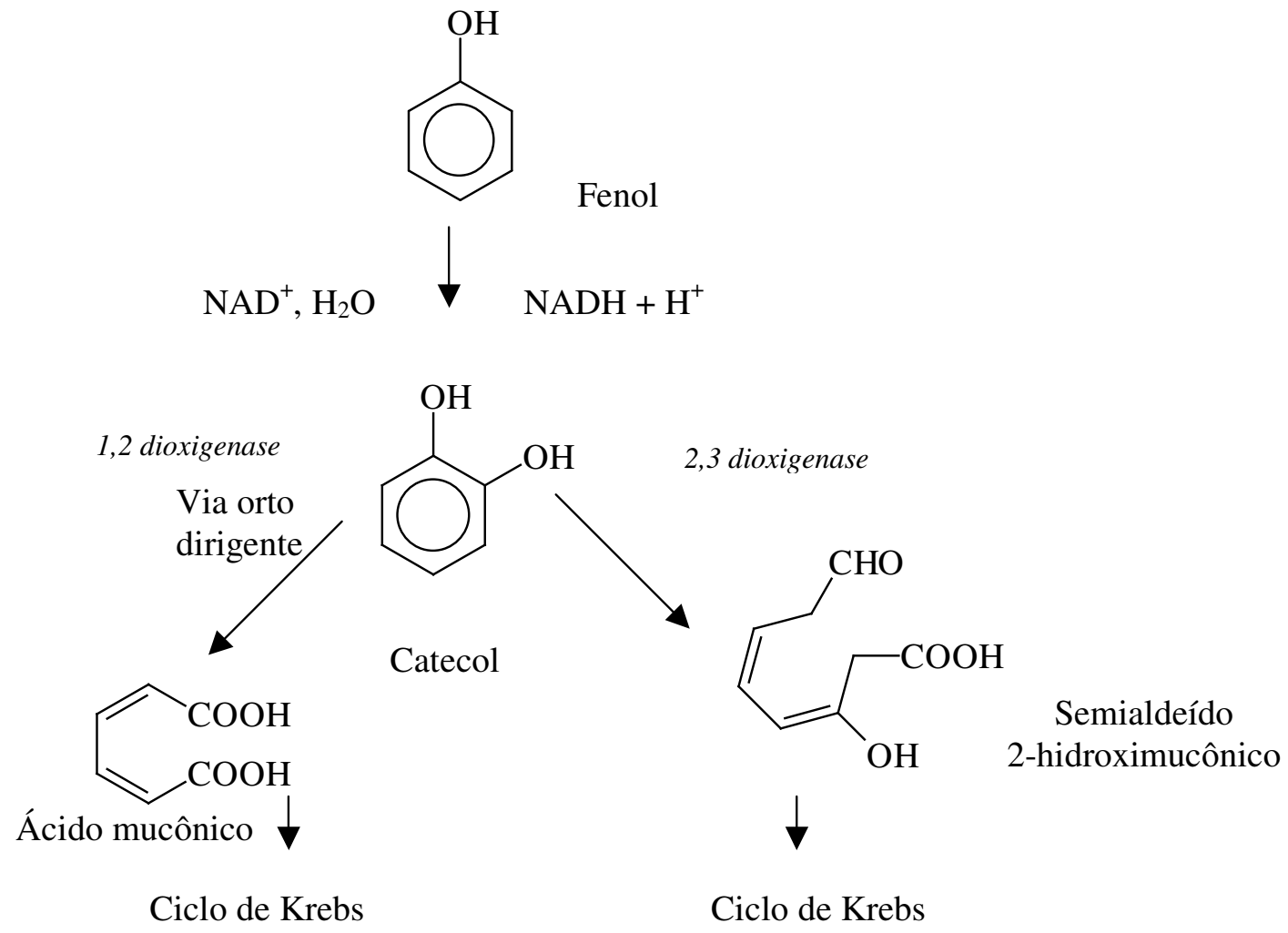

Figura 3.2: Rota aeróbia de degradação do fenol.

Fonte: van Schie e Young (2000)

Rahouti et al. (1999) estudaram o uso de compostos fenólicos por fungos. Os autores utilizaram as espécies Heterobasidion annosum, Paecilomyces variotii, Pestalotia palmarum e Sporormiella antártica e os compostos fenol, catecol, guaiacol, ácido protocatecóico, ácido vanílico, ácido siríngico e ácido felúrico, nas concentrações de $500 \mathrm{mg} / \mathrm{L}$. A maioria dos fungos foi capaz de utilizar os compostos fenólicos, sendo que $74 \%$ das linhagens apresentaram bom crescimento. O uso do composto fenólico foi limitado pela tolerância do fungo ao composto, bem como por sua capacidade de assimilá-lo como fonte de carbono.

Segundo aqueles autores, a ligação de $\mathrm{OH}^{-}$ou $\mathrm{COOH}^{-}$ao composto fenólico, torna mais fácil sua metabolização pelo microrganismo, seguinte ordem: fenol < catecol < ácido protocatecóico; guaiacol < ácido vanílico; e guaiacol < ácido felúrico. A inibição 
do crescimento fúngico ocorreu principalmente na presença de fenol, seguido de catecol e guaiacol.

Santos e Linardi (2004) relataram que fungos dos gêneros Aspergillus, Fusarium, Graphium e Penicillium tem capacidade de utilizar compostos fenólicos como substrato para crescimento e produção de biomassa, sendo o ácido mucônico um produto intermediário da degradação desses compostos. Ao compararem as principais vias catabólicas de degradação de compostos aromáticos para bactérias e fungos, verificaram que a etapa inicial de conversão é conduzida por várias enzimas que atuam sobre o composto, transformando-o em número limitado de intermediários hidroxilados que são, então, conduzidos a rotas de degradação específicas: vias orto e meta.

A etapa limitante do processo de biodegradação do fenol é sua conversão em catecol, na presença de oxigênio. Meios com fontes de carbono facilmente degradáveis podem inibir a produção das enzimas fenol hidroxilase, catalisadores da reação (CÉJKOVÁ et al., 2002), assim como a concentração inicial do poluente pode inibir o crescimento do fungo.

$\mathrm{Na}$ presença de composto tóxico, como é o caso dos compostos fenólicos, os fungos desenvolvem novos mecanismos para acumular componentes intracelulares (polissacarídeos e lipídios) que contribuem para aumentar a biomassa e evitar o efeito do poluente. Assim, a presença do composto tóxico favorece o aumento de massa fúngica e a ramificação do micélio (COSTA et al., 2004).

O efeito do aumento da concentração de vários tóxicos sobre o crescimento da levedura C. maltosa foi pesquisado por Fialová et al. (2004). C. maltosa foi inoculada em frascos contendo $100 \mathrm{~mL}$ de meio de crescimento com aminoácidos $(1,7 \mathrm{~g} / \mathrm{L})$, L-histina $(10 \mathrm{mg} / \mathrm{L})$, DL-metionina $(20 \mathrm{mg} / \mathrm{L})$, DL-tryptofan $(20 \mathrm{mg} / \mathrm{L})$ e sulfato de amônio $(5 \mathrm{~g} / \mathrm{L})$, com pH ajustado em 4,5. Os frascos foram incubados durante $24 \mathrm{~h}$, sob agitação de $150 \mathrm{rpm}$, a $26^{\circ} \mathrm{C}$. Quando do uso do fenol (0,05 a 1,7 g/L), como fonte única de carbono e energia, foi verificado que o aumento da concentração do composto causou a diminuição da velocidade máxima de crescimento $\left(\mu_{\text {máx }}\right)$, indicando a inibição pelo substrato. Ao utilizarem catecol ( 0,3 a $2 \mathrm{~g} / \mathrm{L})$ como fonte de carbono, foram obtidos maiores valores de $\mu_{\text {máx }}$, ficando demonstrada a importância da primeira etapa da biodegradação de fenol e sua dependência da produção da enzima fenol-hidroxilase. 
Fialová et al. (2004) compararam o crescimento de C. maltosa em meio que possuía a glicose $(0,5 \mathrm{~g} / \mathrm{L})$, como fonte de carbono, e em outro cuja fonte de carbono foi o fenol $(0,5 \mathrm{~g} / \mathrm{L})$. Foi observado que, em presença de fenol, as leveduras consumiram cerca de $40 \%$ a mais do oxigênio para que houvesse a produção da enzima fenolhidroxilase.

\subsection{Emprego dos Fungos no Tratamento de Águas Residuárias Contendo Compostos Persistentes}

O emprego de fungos na remoção de poluentes começou a ser estudado nos últimos trinta anos do século XX. De acordo com Rao e Viraraghavan (2002), um dos primeiros trabalhos que se tem notícia foi com uso de Saccharomyces cerevisiae para remoção de lindano e dieldrin por Voermman e Tammes (1969), seguido do trabalho de Iyengar e Prabharkararao (1973) que estudaram a degradação de heptacloro por fungos do gênero Aspergillus. Contudo, foi nas últimas décadas que houve incremento nas pesquisas de biodegradação por fungos.

Segundo Kunz et al. (2001), Phanerochaete chrysosporium foi uma das primeiras espécies de fungos isoladas no início da década de 70, no século XX. Essa espécie apresentou resultados promissores na degradação biológica de compostos persistentes, principalmente devido à produção de enzimas ligninases, peroxidases e manganês peroxidase (ANDER e MAZULLO, 1997; PERALTA-ZAMORA et al. ${ }^{2}$, 1999, apud KUNZ et al., 2001).

A espécie Phanerochaete chrysosporium vem sendo utilizada como inóculo de reatores biológicos em várias pesquisas visando tratamento de diferentes águas residuárias. Contudo, várias espécies fúngicas têm demonstrado sua viabilidade na remoção de vários compostos, conforme mostrado na Tabela 3.5.

\footnotetext{
${ }^{2}$ Peralta-Zamora et al. (1999). Degradation of reactive dyes. Chemosphere (38) apud Kunz et al. (2001). Combined treatment of textile effluent using the sequence Phanerochaete chrysosporium-ozone. Chemosphere (44).
} 
Tabela 3.5: Estudos sobre o uso de espécies fúngicas na remoção de vários compostos.

\begin{tabular}{|c|c|c|c|}
\hline Pesquisador & Reator & Espécie & Composto \\
\hline Santaella (1993) & $\begin{array}{l}\text { Contínuo de leito } \\
\text { fixo }\end{array}$ & $\begin{array}{c}\text { Fusarium, Penicilium, } \\
\text { Epicocum, } \\
\text { Geotrichum e } \\
\text { Trichoderma }\end{array}$ & $\begin{array}{l}\text { Substâncias } \\
\text { húmicas }\end{array}$ \\
\hline $\begin{array}{c}\text { Gharsallah et al. } \\
\text { (1999) }\end{array}$ & Batelada & $\begin{array}{l}\text { Phanerochaete } \\
\text { chrysosporium }\end{array}$ & $\begin{array}{l}\text { Compostos } \\
\text { fenólicos }\end{array}$ \\
\hline $\begin{array}{l}\text { Nagarathnamma } \\
\text { et al. (1999) }\end{array}$ & Batelada & $\begin{array}{c}\text { Ceriporiopis } \\
\text { subvermispora }\end{array}$ & Lignina \\
\hline $\begin{array}{l}\text { Balan e } \\
\text { Monteiro } \\
(2001)\end{array}$ & Batelada & $\begin{array}{c}\text { Phellinus gilvus, } \\
\text { Pycnoporus } \\
\text { sanguineus } \mathrm{e} \\
\text { Pleurotus sajor-caju }\end{array}$ & $\begin{array}{l}\text { Corantes } \\
\text { têxteis }\end{array}$ \\
\hline $\begin{array}{l}\text { Assas et al. } \\
\text { (2002) }\end{array}$ & Batelada & Geotrichum candidum & $\begin{array}{l}\text { Compostos } \\
\text { fenólicos }\end{array}$ \\
\hline $\begin{array}{c}\text { Ambrósio e } \\
\text { Campos-Takaki } \\
(2004)\end{array}$ & Batelada & $\begin{array}{c}\text { Cunninghamella } \\
\text { elegans }\end{array}$ & $\begin{array}{l}\text { Corantes } \\
\text { têxteis }\end{array}$ \\
\hline $\begin{array}{l}\text { Kim et al. } \\
\text { (2004) }\end{array}$ & $\begin{array}{l}\text { Biorreator } \\
\text { híbrido com } \\
\text { membrana } \\
\text { filtrante e } \\
\text { fungos }\end{array}$ & Trametes versicolor & $\begin{array}{l}\text { Corantes } \\
\text { têxteis }\end{array}$ \\
\hline $\begin{array}{l}\text { D'Annibale et } \\
\text { al. (2004) }\end{array}$ & Batelada & Panus tigrinus & $\begin{array}{l}\text { Compostos } \\
\text { fenólicos }\end{array}$ \\
\hline $\begin{array}{l}\text { D'Annibale et } \\
\text { al. (2004) }\end{array}$ & Batelada & Lentinula edodes & $\begin{array}{l}\text { Compostos } \\
\text { fenólicos }\end{array}$ \\
\hline $\begin{array}{l}\text { Denizli et al. } \\
\text { (2004) }\end{array}$ & Batelada & $\begin{array}{l}\text { Phanerochaete } \\
\text { chrysosporium }\end{array}$ & $\begin{array}{l}\text { Fenóis e } \\
\text { clorofenóis }\end{array}$ \\
\hline $\begin{array}{c}\text { Dhouib et al. (in } \\
\text { press) }\end{array}$ & Semi-contínuo & $\begin{array}{l}\text { Phanerochaete } \\
\text { chrysosporium }\end{array}$ & $\begin{array}{l}\text { Compostos } \\
\text { fenólicos }\end{array}$ \\
\hline $\begin{array}{l}\text { Sahoo e Gupta } \\
\text { (2005) }\end{array}$ & Batelada & $\begin{array}{l}\text { Aspergillus flavus e } \\
\text { Aspergillus fumigatus }\end{array}$ & Lignina \\
\hline
\end{tabular}

Santaella (1993) utilizou reator contínuo, de leito fixo e escoamento ascendente, inoculado com Fusarium, Penicilium, Epicocum, Geotrichum e Trichoderma, para 
remover substâncias húmicas de águas naturais. Foi obtida remoção de $80 \%$ de substâncias húmicas, quando da operação do reator com tempo de detenção de 20 dias, e adição de glicose $(0,5 \mathrm{~g} / \mathrm{L})$ como substrato primário.

Gharsallah et al. (1999) estudaram o tratamento de uma água residuária de indústria de azeite de oliva, rica em compostos fenólicos, por Phanerochaete chrysosporium, como pré-tratamento da digestão anaeróbia. $\mathrm{O}$ experimento em batelada foi realizado com a água residuária concentrada (100000 mg DQO/L), em recipiente de $5 \mathrm{~L}$, durante 7 dias. Foi verificado que, no final, do experimento, houve remoção de $50 \%$ de matéria orgânica, de modo que, segundo os autores, os compostos fenólicos com baixas massas moleculares foram prioritariamente degradados, enquanto que os de alto peso molecular foram lentamente despolimerizados.

Balan e Monteiro (2001) estudaram a remoção do corante índigo azul $\left(\mathrm{C}_{12} \mathrm{H}_{8} \mathrm{O}_{2} \mathrm{~N}_{2}\right)$ pelos fungos Phellinus gilvus, Pycnoporus sanguineus e Pleurotus sajorcaju. Os fungos foram cultivados durante 7 dias em meio com extrato de malte para obtenção do micélio $(0,6 \mathrm{mg}$ de massa seca) que foi adicionada em frascos de erlenmeyer $(250 \mathrm{~mL})$ contendo $60 \mathrm{~mL}$ do meio descrito por PONTECORVO 3 et al. (1997) e o corante $(0,02 \% \mathrm{v} / \mathrm{v})$, como única fonte de carbono. Os frascos foram mantidos no escuro, em cultura estática, à temperatura entre $25^{\circ} \mathrm{C} \mathrm{e}$ $30^{\circ} \mathrm{C}$, durante 4 dias. Nas primeiras $24 \mathrm{~h}$, foi visualmente observada a remoção de cor do meio, sendo que não houve alteração do meio no controle. A maior remoção de cor foi alcançada por Phellinus gilvus (100\%), seguidos por Pl. sajor-caju (94\%), Py. sanguineus (91\%) e Ph. chrysosporium (75\%).

Assas et al. (2002) empregaram Geotrichum candidum em reator no regime de batelada, sem agitação mecânica, e mistura promovida por aeração, visando o tratamento de efluente gerado na fabricação de azeite de oliva. Geotrichum candidum cresceu tanto em água residuária fresca (120 g de DQO/L), como envelhecida (160 g de DQO/L), com redução de DQO de 65\% na primeira. A remoção de DQO na água residuária envelhecida foi menor, $25 \%$, sendo esse resultado atribuído à baixa concentração de açúcar, o que impediu o fungo de exercer sua habilidade de remover cor e, consequientemente, a carga orgânica.

\footnotetext{
${ }^{3}$ POTENCORVO et al. (1997). Genetic recombination without sexual reproduction in Aspergillus niger. Gen. Microbiol. 8, $198-210$.
} 
Trametes versicolor foi inoculado em reator, com volume útil de 1,7 L, por Kim et al. (2004) a fim de verificar a remoção dos corantes reativos azul 19, azul 49 e preto 5 , na concentração de $100 \mathrm{ppm}$, e meio contendo glicose $(5 \mathrm{~g} / \mathrm{L})$, tartarato de amônio $(0,22 \mathrm{~g} / \mathrm{L}), \mathrm{KH}_{2} \mathrm{PO}_{4}(0,2 \mathrm{~g} / \mathrm{L}), \mathrm{MgSO}_{4} \cdot 7 \mathrm{H}_{2} \mathrm{O}(0,05 \mathrm{~g} / \mathrm{L}), \mathrm{CaCl}_{2}(0,01 \mathrm{~g} / \mathrm{L})$ e solução de elementos traço $(10 \mathrm{~mL} / \mathrm{L})$. O sistema foi operado com recirculação do efluente, após processo de filtração por osmose reversa. Houve remoção dos corantes em diferentes percentuais: os corantes azul 19 e azul 49, 99\%, em 8 h de reação; o corante preto 5, 99\%, porém, somente após 40 h do início da partida do reator.

D’Annibale et al. (2004) utilizaram Panus tigrinus CBS 577.79, fungo da podridão branca, no tratamento de águas residuárias de indústria de azeite de oliva, com alta (I) e baixa (II) concentração de matéria orgânica, visando remover compostos fenólicos, cor e carga orgânica. As águas residuárias possuíam concentrações de matéria orgânica de $85000 \mathrm{mg}$ DQO/L (I) e 43000 DQO/L (II) e de compostos fenólicos, de $5500 \mathrm{mg} / \mathrm{L}$ (I) e $2900 \mathrm{mg} / \mathrm{L}$ (II), cor $2700 \mathrm{UC}$ e pH de 5,3. Foram realizados ensaios em batelada, durante 13 dias, a $28^{\circ} \mathrm{C}$, sob agitação de $180 \mathrm{rpm}$, usando frascos de $250 \mathrm{~mL}$, contendo $50 \mathrm{~mL}$ das águas residuárias com alta e baixa concentração de matéria orgânica, com adição de sacarose $(0,5 \%)$ e extrato de levedura $(0,1 \%)$. No meio I, a remoção de cor foi de $67 \%$, no $10^{\circ}$ dia, logo após a fase lag de crescimento, e a remoção de cor foi de apenas $25 \%$. Foi verificada a remoção de compostos fenólicos de $89 \%$, no meio II, após $72 \mathrm{~h}$ de experimento. No meio I, os autores observaram ainda, o progressivo escurecimento do micélio fúngico, indicando possível adsorção dos compostos fenólicos pela biomassa e atribuíram a menor eficiência da espécie, devido à maior toxicidade do meio, pela alta concentração de compostos fenólicos.

Em outro trabalho, sobre remoção de compostos fenólicos por fungos, D'Annibale et al. (2004), utilizaram a espécie Lentinula edodes, a qual foi primeiramente adaptada em meio de crescimento contendo $5 \%$ da água residuária, durante $72 \mathrm{~h}$. A biomassa resultante foi separada do líquido por filtração e, em seguida, transferida para frascos com $200 \mathrm{~mL}$ da água residuária (esterilizada a $121^{\circ} \mathrm{C}$, por 20 min), durante 10 dias, sob agitação de $80 \mathrm{rpm}$ a $28 \pm 1{ }^{\circ} \mathrm{C}$. As características da água residuária eram as seguintes: $43000 \mathrm{mg} \mathrm{DQO} / \mathrm{L}, 3700 \mathrm{mg} / \mathrm{L}$ de fenóis, $4800 \mathrm{mg} / \mathrm{L}$ de açúcar, 24000 UC e pH 5,3. L.edodes foi capaz de crescer na água residuária sem adição de suprimento orgânico extra, com remoções máximas de matéria orgânica de $67 \%$ e de fenóis de $88 \%$, após 240 h do início da batelada. Houve acúmulo de compostos 
fenólicos na superfície do micélio que apresentou $8 \%$ e $21 \%$ da concentração inicial de fenóis, após 120 h e 240 h, respectivamente.

A remoção de fenóis e clorofenóis (o-clorofenol, p-clorofenol e 2,4,6 triclorofenol) por Phanerochaete chrysosporium foi estudada por Denizli et al. (2004). Foram observados os efeitos das concentrações iniciais dos compostos e do $\mathrm{pH}$ sobre a taxa e a capacidade de adsorsão dos mesmos pelo fungo. Assim, soluções de fenóis e clorofenóis, com concentrações variando de $25 \mathrm{mg} / \mathrm{L}$ a $1000 \mathrm{mg} / \mathrm{L}$, foram tratadas com a biomassa $(50 \mathrm{mg})$ em diferentes valores de $\mathrm{pH}(2$ a 8$)$. Os resultados obtidos indicaram que a adsorção dos poluentes nas paredes do micélio fúngico ocorreu em função do $\mathrm{pH}$, aumentando com o aumento do $\mathrm{pH}$. Os autores também verificaram a possibilidade reutilizar a biomassa de Phanerochaete chrysosporium, promovendo a desorção de fenol e clorofenóis, usando solução de metanol (30\% v/v) e conseguiram o reaproveitamento do inóculo.

Dhouib et al. (2006) utilizaram Phanerochaete chrysosporium, como inóculo de reator aeróbio de coluna, para pré-tratamento de água residuária de indústria de azeite de oliva. $\mathrm{O}$ reator, volume útil de $10 \mathrm{~L}$, foi operado no regime semi-contínuo, com tempos de detenção de 3 a 5 dias, e o oxigênio foi suprido no meio pelo uso de compressor de ar, com vazão de $0,25 \mathrm{~L} / \mathrm{min}$. A água residuária possuía $\mathrm{pH}$ variando de 4,9 a 6,4 e concentração de matéria orgânica entre $70000 \mathrm{mg}$ DQO/L e $130000 \mathrm{mg}$ $\mathrm{DQO} / \mathrm{L}$, tendo-se adicionado à mesma, $5,2 \mathrm{~g}$ de $\mathrm{NH}_{4} \mathrm{NO}_{3}$ e $0,8 \mathrm{~g}$ de $\mathrm{P}_{2} \mathrm{O}_{5}$. A remoção de matéria orgânica variou de $20 \%$ a $50 \%$ e foi observada a polimerização de polifenóis, fenômeno que ocorre durante o envelhecimento da água residuária. $\mathrm{O} \mathrm{pH}$ do efluente aumentou, variando de 7,5 a 7,8.

Nagarathnamma et al. (1999) estudaram a degradação de compostos lignolíticos em água residuária da indústria de papel e celulose por Ceriporiopis subvermispora. Foram empregados vários substratos primários (glicose, sacarose, xylose, celulose carboximetil, celulose microcristazada, lactose, álcool etil, amido, melaço, soro de queijo, entre outros), na concentração de $1 \mathrm{~g} / \mathrm{L}$, a fim de verificar sua influência na eficiência do processo. A água residuária recebeu, ainda, cloreto de cálcio $(1,5 \mathrm{~g} / \mathrm{L})$, sulfato de magnésio (2 g/L), fosfato dihidrogênio de potássio $(1,5 \mathrm{~g} / \mathrm{L})$, cloreto de amônio, $(0,15 \mathrm{~g} / \mathrm{L})$. A água residuária possuía matéria orgânica variando de $1300 \mathrm{mg}$ DQO/L a 1400 mg DQO/L, lignina de $392 \mathrm{mg} / \mathrm{L}$ a $432 \mathrm{mg} / \mathrm{L}$, cor de 7000 a 7500 unidades de cor e $\mathrm{pH}$ de 10 a 11. Os maiores percentuais de remoção variaram de 80 a 
$88 \%$. A maior remoção de cor $(88 \%)$ ocorreu após 48 h do início do experimento em batelada, em meio com glicose, seguida por xilose, amido, lactose, celulose microcristalizada, celulose carboximetil, álcool etil e soro de queijo, nesta ordem. Os autores também verificaram que aumentos da concentração de glicose, para valores a cima de $1 \mathrm{~g} / \mathrm{L}$, não melhoraram a remoção de cor do meio.

Sahoo e Gupta (2005) isolaram Aspergillus flavus e Aspergillus fumigatus de água residuária de fábrica de papel e estudaram suas atuações quanto à remoção de 3,6 unidades de cor desse despejo. Utilizando frascos de $500 \mathrm{~mL}$, foram adicionados 100 $\mathrm{mL}$ do efluente e glicose $(2 \% \mathrm{~m} / \mathrm{v})$ e incubados à temperatura de $30^{\circ} \mathrm{C}$, sob agitação orbital de $200 \mathrm{rpm}$, durante período de $24 \mathrm{~h}$. As maiores remoções de cor foram alcançadas pelos fungos foram de $89 \%$ e $84 \%$, respectivamente, por Aspergillus fumigatus e Aspergillus flavus. Aqueles autores também observaram que em meios agitados a remoção de cor é maior, pois, ao repetirem o experimento sem agitação, foram obtidos 55,5\% e 53,5\% de remoção de cor, respectivamente, por Aspergillus fumigatus e Aspergillus flavus.

As concentrações de açúcares (glicose, sacarose e frutose) são fatores importantes em processo de remoção de cor em águas residuárias. Miranda et al. (1996) estudaram o efeito da concentração de açúcar sobre a remoção de cor de efluente contendo melaço da cana-de-açúcar e verificaram que glicose e frutose são açúcares rapidamente utilizados, com a remoção de cor paralela ao consumo de açúcares e crescimento de micélio.

A influência do substrato primário sobre o metabolismo fúngico, visando remoção de cor, foi estudada por Ambrósio e Campos-Takaki (2004). O fungo Cunningamella ellegans $\left(3,8 \times 10^{8}\right.$ esporos $\left./ \mathrm{mL}\right)$ foi inoculado em frascos de $250 \mathrm{~mL}$, contendo $95 \mathrm{~mL}$ de meio Saboraud, com diferentes combinações: I - peptona (10 g/L), sacarose (20 g/L), $\mathrm{KH}_{2} \mathrm{PO}_{4}(0,5 \mathrm{~g} / \mathrm{L}) ; \mathrm{II}$ - peptona $(10 \mathrm{~g} / \mathrm{L}), \mathrm{KH}_{2} \mathrm{PO}_{4}(0,5 \mathrm{~g} / \mathrm{L}) ; \mathrm{III}$ - sacarose $(20 \mathrm{~g} / \mathrm{L})$, $\mathrm{KH}_{2} \mathrm{PO}_{4}(0,5 \mathrm{~g} / \mathrm{L})$ e IV $-\mathrm{KH}_{2} \mathrm{PO}_{4}(0,5 \mathrm{~g} / \mathrm{L})$. Foi adicionado, ainda, o corante têxtil preto 5, ou o vermelho 198, ou laranja 11. Os autores observaram que a espécie fúngica foi capaz de utilizar os corantes em todos os meios estudados, sendo que, nos frascos com o corante laranja 11, a remoção de cor pelo fungo foi maior nos meios I e III, enquanto que, nos frascos com o corante vermelho, melhores resultados foram obtidos nos meios II e IV. Os resultados indicaram a existência de relação de seletividade entre a composição do meio e a estrutura do corante, pois, embora, a presença de sacarose e 
peptona (I) tenha sido importante para a remoção do corante nos frascos com o corante laranja 11 (83\%, após 96 h), não exerceu grande influência sobre o uso dos demais corantes pelo fungo. Foi verificado ainda, que as remoções de cores foram pouco expressivas nos frascos com o meio que recebeu apenas $\mathrm{KH}_{2} \mathrm{PO}_{4}$ (IV), com o melhor resultado obtido para o corante preto 5 , com $40 \%$ de remoção.

Os fungos do gênero Aspergillus têm demonstrado grande potencial para o tratamento de águas residuárias com compostos fenólicos e são utilizadas como inóculo de reatores devido à sua capacidade de produzir enzimas, como fenol hidroxilase (BORJA et al., 1995, e MIRANDA et al., 1996), particularmente, a espécie Aspergillus niger.

$\mathrm{Na}$ Tabela 3.6 são mostradas pesquisas com o uso de Aspergillus niger na remoção de diferentes poluentes.

A espécie Aspergillus niger tem sido empregada com grande sucesso no tratamento de efluente da indústria de azeite de oliva - despejo muito rico em compostos fenólicos (BORJA et al., 1995; GARCÍA et al., 2000) - e outras espécies do referido gênero têm sido isoladas desses despejos (CIAFARDINI e ZULLO, 2002).

Em 1996, Peña-Miranda et al. estudaram a remoção de cor de água residuária contendo melaço pelo uso de Aspergillus niger em reatores do tipo batelada e contínuo. A água residuária, com concentração de matéria orgânica de 16000 mg DQO/L e pH entre 8 e 9, diminuído para $\mathrm{pH} 5$, foi esterilizada a $120^{\circ} \mathrm{C}$, durante 20 minutos, antes de ser utilizada. Os reatores em batelada possuíam volume reacional de $350 \mathrm{~mL}$, mantidos à temperatura de $30^{\circ} \mathrm{C}$, e agitação de $200 \mathrm{rpm}$, durante 3 dias, variando-se as concentrações de glicose (1 a $20 \mathrm{~g} / \mathrm{L}$ ). Os resultados da batelada mostraram que a glicose foi prontamente consumida do meio e a maior remoção de cor (69\%) foi alcançada com $10 \mathrm{~g} / \mathrm{L}$, ocorrendo diminuição da eficiência de remoção para valores menores ou maiores. O processo contínuo foi realizado em reator tubular com volume útil $5 \mathrm{~L}$, operado com o TDH de 5 dias, sendo o ar fornecido por compressores conectados a difusores para melhor distribuição no interior do reator. A remoção maxima de cor foi de $37 \%$ e de matéria orgânica, de $69 \%$. 
Tabela 3.6: Uso de Aspergillus niger na remoção de poluentes.

\begin{tabular}{|c|c|c|c|}
\hline Pesquisador & Reator & Poluente & Microrganismos \\
\hline $\begin{array}{c}\text { Peña-miranda et al. } \\
\text { (1996) }\end{array}$ & $\begin{array}{l}\text { Batelada e } \\
\text { Contínuo }\end{array}$ & Melaço & Aspergillus niger \\
\hline $\begin{array}{c}\text { Vassilev et al. } \\
\text { (1997) }\end{array}$ & $\begin{array}{l}\text { Batelada } \\
\text { Seqüencial }\end{array}$ & $\begin{array}{l}\text { Compostos } \\
\text { fenólicos }\end{array}$ & Aspergillus niger \\
\hline $\begin{array}{l}\text { Kapoor et al. } \\
\text { (1999) }\end{array}$ & Batelada & Metais pesados & Aspergillus niger \\
\hline Garcia et al. (2000) & Batelada & $\begin{array}{l}\text { Compostos } \\
\text { fenólicos }\end{array}$ & $\begin{array}{c}\text { Aspergillus niger, } \\
\text { Phanerochaete } \\
\text { chrysosporium, } \\
\text { Aspergillus terreus e } \\
\text { Geotrichum candidum }\end{array}$ \\
\hline $\begin{array}{c}\text { Assadi e } \\
\text { Jahangiri, (2001) }\end{array}$ & Airlift & Corantes têxteis & Aspergillus niger \\
\hline Price et al. (2001) & Batelada & Metais pesados & Aspergillus niger \\
\hline $\begin{array}{c}\text { Fu e Viraraghavan } \\
\text { (2002) }\end{array}$ & Batelada & Corantes têxteis & Aspergillus niger \\
\hline $\begin{array}{l}\text { Rao e Viraraghavan } \\
\qquad(2002)\end{array}$ & $\begin{array}{l}\text { Reartor de coluna } \\
\text { com vazão } \\
\text { descendente }\end{array}$ & Fenol & Aspergillus niger \\
\hline Goyal et al (2003) & Batelada & Metais pesados & $\begin{array}{c}\text { Streptococcus equisimilis, } \\
\text { Sacharomyces cerevisiae e } \\
\text { Aspergillus niger }\end{array}$ \\
\hline Cereti et al (2004) & Airlift & $\begin{array}{l}\text { Compostos } \\
\text { fenólicos } \\
\text { Compostos }\end{array}$ & Aspergillus niger \\
\hline Kotsou et al (2004) & Batelada/Contínuo & fenólicos & Aspergillus niger \\
\hline $\begin{array}{l}\text { Kyriacou et al. } \\
\qquad(2005)\end{array}$ & Batelada & $\begin{array}{c}\text { Compostos } \\
\text { fenólicos } \\
\text { Metil paration e } \\
\text { atrazina }\end{array}$ & Aspergillus niger \\
\hline
\end{tabular}

Vassilev et al. (1997) utilizaram Aspergillus niger como inóculo de reator biológico aeróbio, no regime de batelada sequencial, para tratamento de efluente do processamento de azeite de oliva. Foram empregadas três complementações diferentes: nitrogênio, fósforo e nitrogênio + fósforo. O inóculo $\left(3 \times 10^{6}\right.$ esporos $\left./ \mathrm{mL}\right)$ foi previamente imobilizado em espuma de poliuretano $\left(0,3 \mathrm{~cm}^{3}\right)$, durante germinação de 
$48 \mathrm{~h}$ em meio à base de glicose. Após esse período, o inóculo imobilizado nas espumas de poliuretano foi lavado com água destilada esterilizada e transferido para frascos de $250 \mathrm{~mL}$, contendo $100 \mathrm{~mL}$ da água residuária em questão, onde permaneceu sob agitação de $200 \mathrm{rpm}$, a $30^{\circ} \mathrm{C}$. O descarte da água residuária, tratada ocorreu após cada $48 \mathrm{~h}$, abrangendo 5 ciclos de esvaziamento e enchimento. A maior redução de fenol foi de, aproximadamente, $67 \%$, obtida a partir de concentração inicial de 6,0 g/L, no quarto ciclo, com meio suplementado com nitrogênio + fósforo.

Em experimento em batelada para tratamento de água residuária de indústria de azeite de oliva, García et al. (2000) verificaram, entre as espécies Aspergillus niger, Aspergillus terreus, Geotrichum candidum e Phanerochaete chrysosporium, a mais eficiente na remoção de fenóis e de DQO. Com exceção de Geotrichum candidum, todas as espécies foram capazes de reduzir DQO e fenóis. Phanerochaete chrisosporium foi a espécie mais eficiente na remoção de fenóis presente na água residuária em questão (92\%), seguidos por Aspergillus niger (76\%) e Aspergillus terreus (64\%).

A espécie Aspergillus niger foi utilizada como inóculo de reator "airlift", operado no regime de batelada alimentada, para tratamento de água residuária de indústria têxtil, por Assadi e Jahangiri (2001). Os autores adicionaram glicose na água residuária, como fonte primária de carbono, em diferentes concentrações, e verificaram que, na ausência de glicose, não ocorreu remoção de cor. Somente foi alcançado bom resultado quando a glicose foi adicionada na concentração de $3 \mathrm{mg} / \mathrm{L}$, obtendo-se $97 \%$ de remoção de cor; para concentrações menores a remoção foi pequena.

Cereti et al. (2004) utilizaram um reator "arlift", de volume útil de $4 \mathrm{~L}$, com inóculo de Aspergillus niger NB2 (10 esporos/mL) para tratamento de água residuária de fábrica de azeite de oliva, com matéria orgânica na concentração de $36000 \mathrm{mg}$ DQO/L, fenóis totais de $1530 \mathrm{mg} / \mathrm{L}$, açúcares totais de $1670 \mathrm{mg} / \mathrm{L}$ e pH de 5,25. O ar foi provido no meio por uso de compressores, com vazão de 2 v.v.m. A operação ocorreu no regime de batelada repetida, sendo que a cada $48 \mathrm{~h}$, parte do líquido foi removido (90\%) e o reator realimentado, perfazendo o total de 5 ciclos. A capacidade dos fungos em remover os poluentes do meio aumentou com o tempo e a maior remoção de matéria orgânica (64\%), medida em DQO, e de açúcares (59\%) ocorreu no quarto ciclo, porém a remoção de compostos fenólicos foi de apenas $10 \%$, no mesmo ciclo. 
A espécie Aspergillus niger foi utilizada por Kotsou et al. (2004) no tratamento de água residuária com alta concentração de compostos fenólicos. A água residuária oriunda do processo de esmagamento de azeitonas, apresentava DQO oscilando entre 9000 e $15000 \mathrm{mg} / \mathrm{L}$ e $\mathrm{pH}$ em torno de $12 . \mathrm{O} \mathrm{pH}$ foi corrigido para 4,5 com uso de ácido sulfúrico. O reator aeróbio, um tubo em vidro com 1,4 m de comprimento e volume total de $12 \mathrm{~L}$, foi operado durante 2 dias, em regime de batelada, e, após esse período, em operação contínua, com tempo de detenção de 2 dias e recirculação de biomassa de $80 \%$. Os autores obtiveram, após 2 dias de operação em batelada, remoção de DQO de $76 \%$ e de, aproximadamente, $70 \%$ na operação contínua. Os autores não apresentaram a concentração inicial de fenol na água resdiduária, porém relataram que as remoções de fenóis alcançadas durante o regime contínuo foram de $41 \%$ para concentração total de fenóis e de $85 \%$, em relação aos fenóis de menor peso molecular.

Kyriacou et al. (2005) também estudaram o tratamento de água residuária da fábrica de azeite de oliva pelo uso de Aspergillus niger $\left(10^{4}\right.$ e $10^{6}$ esporos $\left./ \mathrm{mL}\right)$. As concentrações de matéria orgânica variaram entre 8000 mg DQO/L e 35000 mg DQO/L e o $\mathrm{pH}$, de 10 a 12 . O experimento foi primeiramente conduzido em batelada, durante 4 dias, em frascos contendo $400 \mathrm{~mL}$ da água residuária acidificada com ácido sulfúrico até $\mathrm{pH}$ de 4,5 a 5,0. Foi verificado que a quantidade de esporos utilizada no inóculo influenciou no tratamento: a concentração de $10^{6}$ esporos/mL resultou em percentual maior de remoção de matéria orgânica $(86 \%)$, em relação à concentração de $10^{4}$ esporos/mL (72\%), e também em valores mais baixos de $\mathrm{pH}$, devido a produção de ácidos, indicando maior atividade metabólica do Aspergillus niger.

Sampaio (2005), em experimento em batelada, verificou a remoção dos pesticidas metil paration $(0,21$ a $25 \mathrm{mg} / \mathrm{L})$ e atrazina $(1,3$ a $11,3 \mathrm{mg} / \mathrm{L})$ por Aspergillus niger AN 400 ( 2 × $10^{6}$ esporos/mL), de uma água, suplementada com cloranfenicol (0,05 g/L) e solução Vishinac (1 $\mathrm{mL} / \mathrm{L})$, contendo etileno diamino tetracético $(10 \mathrm{~g} / \mathrm{L})$,

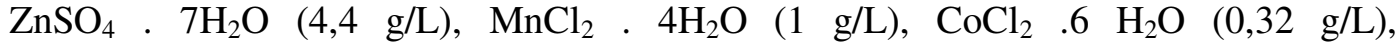
$\left(\mathrm{NH}_{4}\right)_{6} \mathrm{Mo}_{7} \mathrm{O}_{24} \cdot 4 \mathrm{H}_{2} \mathrm{O}(0,22 \mathrm{~g} / \mathrm{L}), \mathrm{CaCl}_{2} \cdot 2 \mathrm{H}_{2} \mathrm{O}(1,47 \mathrm{~g} / \mathrm{L}), \mathrm{FeSO}_{4} \cdot 7 \mathrm{H}_{2} \mathrm{O}(1 \mathrm{~g} / \mathrm{L})$, com e sem adição de glicose $(0,5 \mathrm{~g} / \mathrm{L})$. A presença de glicose favoreceu melhores percentuais de remoção de metil paration, quando comparada com os reatores que não continham o substrato primário. A constante cinética obtida nos reatores com glicose e metil paration foi de $0,162 \pm 0,014 \mathrm{~h}^{-1}$, enquanto que nos que não receberam glicose, a constante cinética foi de $0,063 \pm 0,005 \mathrm{~h}^{-1}$, reflexo de maior velocidade de conversão do substrato 
em meio contendo glicose. O melhor percentual de remoção de $0,62 \mathrm{mg} / \mathrm{L}$ de metil paration alcançado foi de $82 \%$, indicando que a glicose atuou em processo de cometabolismo para remoção do inseticida. Porém, quando do experimento com atrazina, a presença da glicose não influenciou na remoção do tóxico. Percentuais de remoção muito próximos foram encontrados nos reatores com e sem glicose; as velocidades de consumo de $0,023 \mathrm{~d}^{-1}$ e de $0,022 \mathrm{~d}^{-1}$, foram determinadas nos reatores que receberam apenas a atrazina e atrazina e glicose, respectivamente.

Conclui-se, portanto, o grande potencial dos fungos de degradar diferentes compostos, particularmente, os persistentes, devido à capacidade destes microrganismos de produzir grande número de enzimas, o que têm despertado interesse para solucionar problemas relacionados ao meio ambiente (LUKE e BURTON, 2001). Este é um dos motivos pelo qual se tem intensificado os estudos sobre reatores biológicos com fungos para o tratamento de águas residuárias industriais, bem como sua utilização em combinação com sistemas anaeróbios e tratamento químico, uma vez que os fungos melhoram a eficiência global de remoção de vários poluentes (GARCIA et al., 1997; D’ANNIABLE et al., 1998).

Pouco ainda se sabe sobre o comportamento metabólico desses microrganismos quando aplicados em reatores para o tratamento de águas residuárias, tornando-se necessário estudos para a otimização dos reatores com fungos, o que conduz a buscar maiores esclarecimentos sobre a utilização ou não de co-substrato, o material empregado como suporte e o melhor tempo de detenção hidraúlica. 


\section{MATERIAL E MÉTODOS}

A pesquisa foi realizada em dois tipos de reatores: batelada e contínuos de leito fixo. No experimento em batelada, foram utilizados reatores inoculados com esporos de Aspergillus niger para avaliar o potencial da espécie na degradação de fenol de água residuária sintética. No experimento com os reatores contínuos, foram utilizados dois meios suportes: manta de polipropileno (reator $\mathrm{R}_{1}$ ) e espuma de poliuretano (reator $\mathrm{R}_{2}$ ). Os reatores receberam esporos de Aspergillus niger como inóculo e foram operados nos tempos de detenção hidráulica de 8 h, 4 h e 6 h.

Na Figura 4.1 são apresentados os esquemas das atividades desenvolvidas durante os experimentos.

\section{Batelada}

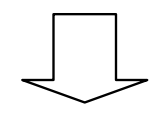

Inóculo:

Aspergillus niger

Substrato:

Água residuária sintética com fenol

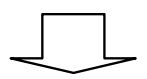

Análises físicas e químicas e microscopia.

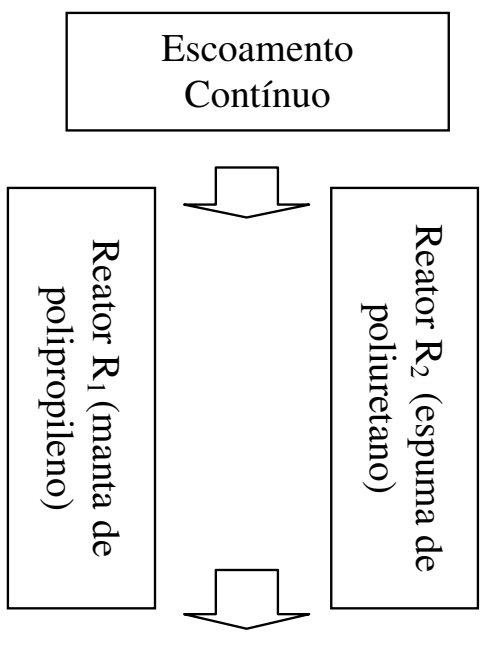

TDH: 8 h (Fases I e II); 4 h e 6 h

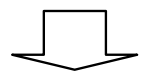

Ensaio de adsorção e análises físicas e químicas e microscopia.

Figura 4.1: Esquemas das atividades desenvolvidas durante o experimento. 


\subsection{Escolha da Espécie de Fungo para Inóculo dos Reatores}

Com base em material bibliográfico, foi escolhida a espécie Aspergillus niger, empregada com êxito na remoção de efluentes contendo substâncias persistentes, como fenol e compostos derivados, conforme trabalhos de Miranda et al. (1996), Vassilev et al. (1997), Assadi e Jahangiri (2001), Garcia et al. (2000), Kotsou et al. (2004) e Kyriacou et al. (2005).

\subsection{Inóculo}

Aspergillus niger AN 400, utilizado como inóculo, foi cedido pela Universidade Federal do Ceará, na forma de suspensão de esporos $\left(2 \times 10^{6}\right.$ esporos $\left./ \mathrm{mL}\right)$.

\subsection{Composição da Água Residuária Sintética}

A água residuária preparada foi baseada em informações obtidas dos trabalhos de Vassilev et al. (1997), Swift et al. (2000), García-Penã et al. (2001) e Kapdan e Kargi (2002). As concentrações dos componentes usados na preparação da água residuária sintética, dissolvidos em água de abastecimento, são mostradas na Tabela 4.1.

Tabela 4.1: Composição da água residuária sintética

\begin{tabular}{|c|c|c|}
\hline \multicolumn{2}{|c|}{ Constituinte } & \multirow[b]{2}{*}{ Concentração (g/L) } \\
\hline Nome & Fórmula & \\
\hline Fenol & $\mathrm{C}_{6} \mathrm{H}_{11} \mathrm{OH}$ & 0,25 \\
\hline Sulfato de amônio & $\left(\mathrm{NH}_{4}\right)_{2} \mathrm{SO}_{4}$ & 2,00 \\
\hline Nitrato de sódio & $\mathrm{NaNO}_{3}$ & 1,00 \\
\hline $\begin{array}{l}\text { Fosfato dihidrogeno de } \\
\text { potássio }\end{array}$ & $\mathrm{KH}_{2} \mathrm{PO}_{4}$ & 0,20 \\
\hline Sulfato de magnésio & $\mathrm{MgSO}_{4}$ & 0,25 \\
\hline $\begin{array}{l}\text { Cloreto de cálcio } \\
\text { dihidratado }\end{array}$ & $\mathrm{CaCl}_{2} \cdot 2 \mathrm{H}_{2} \mathrm{O}$ & 0,01 \\
\hline $\begin{array}{l}\text { Sulfato de cobre } \\
\text { heptahidratado }\end{array}$ & $\mathrm{CuSO}_{4} .7 \mathrm{H}_{2} \mathrm{O}$ & 0,08 \\
\hline Ácido molibídico & $\mathrm{H}_{2} \mathrm{MoO}_{4}$ & 0,05 \\
\hline $\begin{array}{l}\text { Sulfato de manganês } \\
\text { pentahidratado }\end{array}$ & $\mathrm{MnSO}_{4} \cdot 7 \mathrm{H}_{2} \mathrm{O}$ & 0,05 \\
\hline Sulfato férrico & $\mathrm{Fe}_{2}\left(\mathrm{SO}_{4}\right)_{3}$ & 0,05 \\
\hline Sulfato de zinco & $\mathrm{ZnSO}_{4}$ & 0,04 \\
\hline
\end{tabular}


Para o ensaio em batelada, a solução foi esterilizada em autoclave, durante 20 minutos, sob pressão de 1 atm e à temperatura de $120^{\circ} \mathrm{C}$. O fenol foi adicionado, após o resfriamento da água residuária.

Quando da operação dos reatores de leito fixo a água residuária não foi esterilizada, pois o grande volume necessário (30 a 60 L), inviabilizou a esterilização.

\subsection{Reatores em batelada}

Foram utilizados 15 frascos de Duran, de $500 \mathrm{~mL}$, sendo cinco com função de controle (RC), cinco com fungos e água residuária sem glicose $(\mathrm{RF})$ e cinco com fungos e água residuária com glicose (RFG). Cada reator foi preenchido com $250 \mathrm{~mL}$ da água residuária sintética. $\mathrm{O}$ pH da água residuária foi diminuído de 6,0 para 4,0, com solução de ácido clorídrico a $10 \%$, a fim de favorecer o desenvolvimento do Aspergillus niger. Os frascos foram vedados com tampão de algodão envolvido por gaze.

Antes da partida da batelada, a fim de caracterizar o meio, retirou-se alíquota de $10 \mathrm{~mL}$ de cada reator, as quais compuseram uma amostra composta.

Em capela, $2 \times 10^{6}$ esporos/mL foi adicionado como inóculo, em cada reator, sendo o procedimento realizado na proximidade da chama do bico de Bunsen, a fim de evitar contaminação.

Os reatores foram mantidos em mesa agitadora horizontal, sob agitação orbital de $200 \mathrm{rpm}$ e temperatura de $30^{\circ} \mathrm{C}$. Um reator de cada tipo (RC, RF e RFG) foi retirado a cada dia de operação, durante cinco dias, conforme mostrado na Tabela 4.2.

Tabela 4.2: Tempo de duração do ensaio em batelada.

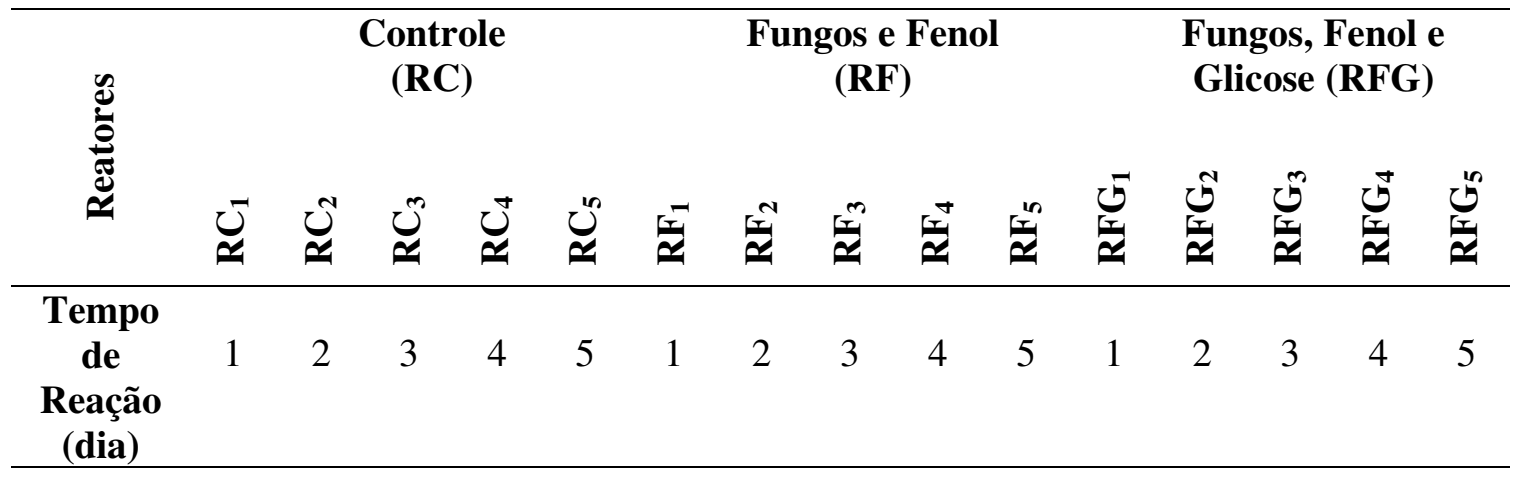




\subsubsection{Tratamento dos Dados Cinéticos}

O modelo matemático de Boltzman (Equação 4.1) foi ajustado aos dados experimentais de $\mathrm{C} / \mathrm{C}_{\mathrm{o}}$ em função do tempo (t), com a ajuda do programa computacional Microcal Origin 6.0 ®. Na Equação (4.1): $C / C_{0}$ - concentração normalizada do substrato $(\mathrm{mg} / \mathrm{L}) ;\left(\mathrm{C} / \mathrm{C}_{\mathrm{o}}\right)_{i}$ - concentração inicial normalizada do substrato $(\mathrm{mg} / \mathrm{L})$; $\left(\mathrm{C} / \mathrm{C}_{\mathrm{o}}\right)_{\mathrm{R}}$ - concentração residual normalizada do substrato $(\mathrm{mg} / \mathrm{L}) ; \mathrm{C}_{\mathrm{o}}$ - concentração inicial do substrato (mg/L); C - concentração de substrato no tempo " $\mathrm{t}$ " (mg/L); t tempo t (dia); $t_{\mathrm{o}}$ - tempo inicial (dia); dx - tamanho do trecho onde a variação em $\mathrm{x}$ implica na maior variação em y.

$$
\frac{C}{C_{o}}=\left(\frac{C}{C_{o}}\right)_{R}+\frac{\left(\frac{C}{C_{o}}\right)_{i}-\left(\frac{C}{C_{o}}\right)_{R}}{1+e^{\frac{\left(t-t_{o}\right)}{d x}}}
$$

Posteriormente, calculadas as velocidades de consumo de fenol $\left(\mathrm{r}_{\mathrm{s}}\right)$ pela Equação (4.2), a partir das quais, encontrou-se a velocidade média ( $\left.\mathrm{r}_{\text {média }}\right)$ de consumo, calculada de acordo com a Equação (4.3), para cada situação (reatores RFG e RF), e a velocidade máxima $\left(\mathrm{r}_{\text {máx }}\right)$, obtida quando $\mathrm{dr} / \mathrm{dt}=0$.

$$
r_{s}=\frac{d\left(\frac{C}{C_{o}}\right)_{i}}{d t}
$$

$$
r_{\text {média }}=\frac{\int r_{s} d t}{\int d t}
$$




\subsection{Reatores Contínuos de Leito Fixo}

\subsubsection{Meios Suportes}

Manta de polipropileno e espuma de poliuretano foram utilizados como meios suportes para a imobilização dos fungos.

A manta de polipropileno, com espessura de $2,15 \mathrm{~mm}$ e porosidade de $90 \%$, foi cortada em retângulos de $2 \mathrm{~cm} \times 3 \mathrm{~cm}$, agrupados em sacos de polietileno permeáveis, formando pequenas esferas ( $9 \mathrm{~g})$, acondicionadas no interior do reator $\mathrm{R}_{1}$.

$\mathrm{O}$ reator $\mathrm{R}_{2}$ recebeu matrizes cúbicas de espuma de poliuretano, com densidade aparente de $23 \mathrm{~kg} / \mathrm{m}^{3}$ e arestas de $1 \mathrm{~cm}$.

\subsubsection{Reatores}

Os reatores foram construídos com tubos cilíndricos de acrílico, com diâmetro externo de $100 \mathrm{~mm}$, espessura das paredes de $5 \mathrm{~mm}$, altura de $0,8 \mathrm{~m}$ e volume total de 4,45 L, com entrada e saída para a água residuária e entrada para aeração, fornecida por mini-compressor de ar (vazão de ar de $150 \mathrm{~L} / \mathrm{h}$ e potência de $5 \mathrm{~W}$ ), conforme mostrado na Figura 4.1. A entrada de ar e de água residuária localizava-se na parte inferior do reator e a saída para o efluente, no topo do reator.

Ao longo do eixo longitudinal dos reatores foram colocados contentores, placas perfuradas de PVC, possuindo no centro passagem para uma haste em inox, fixada por encaixe no fundo do reator. A função dos contentores foi a de evitar o deslocamento do meio suporte e seu conseqüente arraste do reator. 


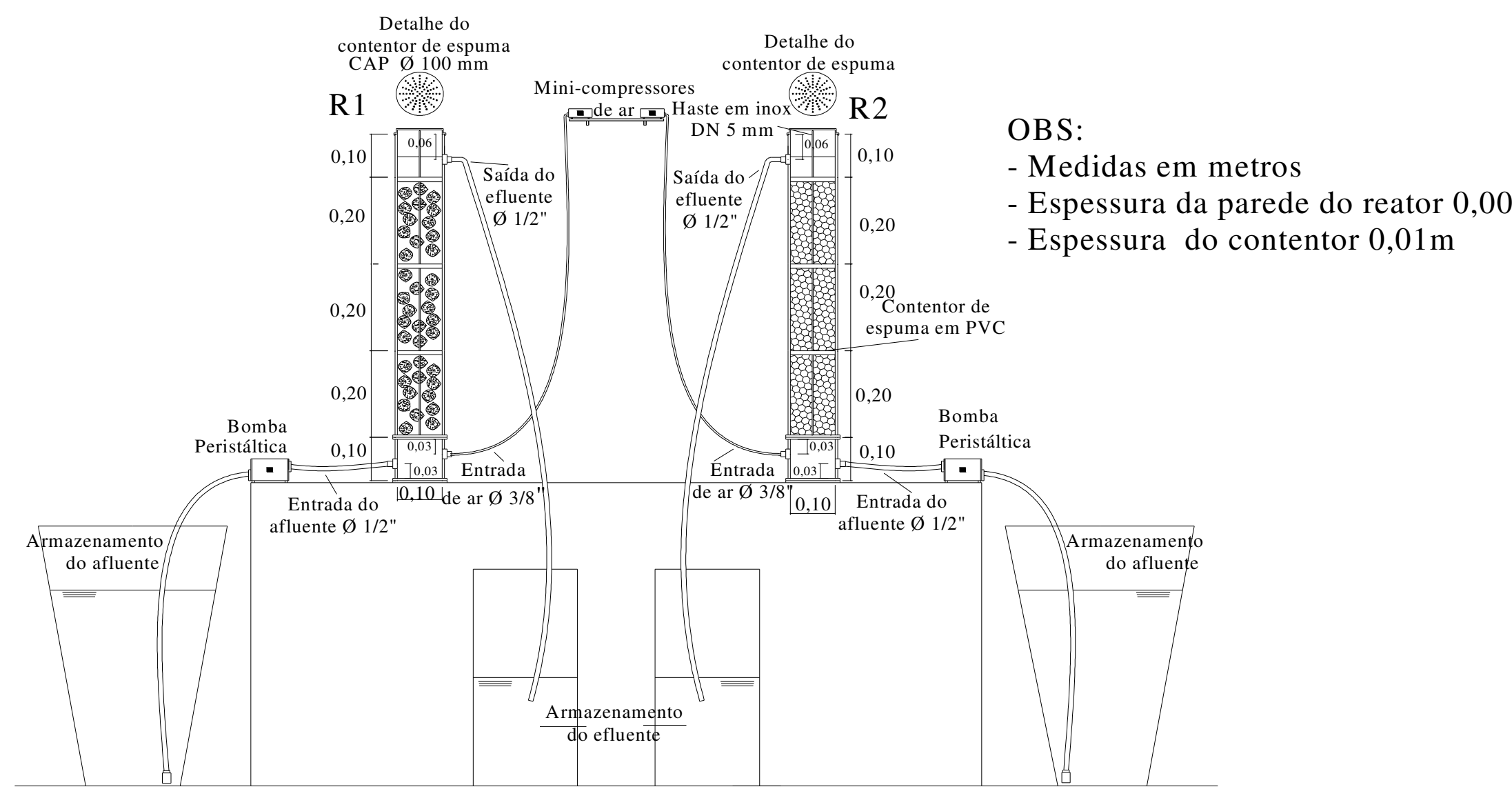

Figura 4.1: Reatores de leito fixo e escoamento ascendente: com meio suporte de manta de polietileno $\left(\mathrm{R}_{1}\right)$ e espuma de poliuretano $\left(\mathrm{R}_{2}\right)$. 
A concentração de fenol na água residuária foi de, aproximadamente, $250 \mathrm{mg} / \mathrm{L}$.

Os reatores foram cobertos com sacos pretos de polietileno, a fim de prevenir perdas de fenol por fotodegradação (RAO e VIRARAGHAVAN, 2002) e submetidos, simultaneamente, aos tempos de detenção hidráulica (TDH), apresentados na Tabela 4.3, com base no volume útil $(2,4 \mathrm{~L})$.

Tabela 4.3: Tempos de detenção hidráulica aos quais foram submetidos os reatores com meio suporte de manta de polipropileno $\left(\mathrm{R}_{1}\right)$ e de espuma de poliuretanpo $\left(\mathrm{R}_{2}\right)$, em função do volume útil.

\begin{tabular}{ccc}
\hline & TDH (h) & Vazão (L/h) \\
\hline $\mathbf{8}$ & $\begin{array}{c}\text { Fase I } \\
\text { (com glicose) } \\
\text { Fase II } \\
\mathbf{4}\end{array}$ & $0,56 \pm 0,03$ \\
$\mathbf{6}$ & & $0,56 \pm 0,03$ \\
\hline
\end{tabular}

O tempo de detenção hidráulica de $8 \mathrm{~h}$ foi dividido em duas fases: com a adição de 0,5 g/L de glicose na água residuária, Fase I, e sem adição de glicose na água residuária, Fase II. Nos demais tempos de detenção hidráulica (4 h e 6 h), os reatores foram operados sem adição de glicose à água residuária.

$\mathrm{O} \mathrm{pH}$ do afluente aos reatores foi mantido em faixa ácida $(3,5$ a 4,0) para favorecer o crescimento de Aspergillus niger e minimizar a possibilidade de contaminação por outras espécies.

\subsubsection{Porosidade do leito}

As porosidades dos leitos $(\xi)$ dos reatores $\mathrm{R}_{1}$ e $\mathrm{R}_{2}$ iguais a, respectivamente, $53 \% \mathrm{e}$ $54 \%$ e foram calculadas de acordo com a Equação (4.4). 


$$
\xi=\frac{V_{\text {útil }}}{V_{\text {Total }}}
$$

- Reator $\mathrm{R}_{1}$ :

$$
\xi=\frac{2,36}{4,45}=0,53
$$

○ Reator $\mathrm{R}_{2}$ :

$$
\xi=\frac{2,40}{4,45}=0,54
$$

\subsubsection{Ensaio de Adsorção nos Meios Suportes}

O ensaio de adsorção foi realizado nos reatores de leito fixo para verificar a capacidade dos materiais empregados como meios suportes de adsorver fenol.

Este ensaio foi efetuado antes da inoculação dos reatores e, portanto, obtido sem interferência do fator biológico e foi importante como ferramenta para comprovar que a remoção do fenol decorreu da ação dos microrganismos presentes nos reatores.

O tempo de detenção hidráulica empregado para o ensaio, em ambos os reatores, foi de $2 \mathrm{~h}$.

Realizou-se acompanhamento da concentração de fenol no efluente do reator a fim de verificar a retenção do poluente no meio suporte. A concentração de fenol no afluente foi de $700 \mathrm{mg} / \mathrm{L}$ no ensaio realizado no reator com meio suporte de manta de polipropileno e de $570 \mathrm{mg} / \mathrm{L}$, no que recebeu espuma de poliuretano como meio suporte.

O ensaio realizado no reator com meio suporte de manta de polipropileno $\left(\mathrm{R}_{1}\right)$ ocorreu durante $1,0 \mathrm{~h}$, com amostras retiradas a cada 10 minutos. Para o reator $\mathrm{R}_{2}$, a concentração de fenol efluente foi quantificada a cada 2 horas, por período de $14 \mathrm{~h}$.

Os reatores $\mathrm{R}_{1}$ e $\mathrm{R}_{2}$, apresentavam, respectivamente, $135 \mathrm{~g}$ e 63,5 g de meio suporte. A partir dos dados de concentração de entrada e saída de fenol, da vazão resultante do tempo de detenção hidráulica empregado no ensaio $(1,2 \mathrm{~L} / \mathrm{h})$, dada em 
função do volume útil de 2,4 L e da variação do tempo (h), estimou-se a concentração total de fenol adsorvido no meio suporte.

O mesmo procedimento foi realizado com os dados de concentração de fenol oriundos da operação do reator, a fim de verificar a concentração total do poluente removido pelos sistemas e averiguar se a remoção alcançada ultrapassou a capacidade de adsorção dos materiais suportes.

\subsubsection{Adição do inóculo e alimentação dos reatores}

Cada reator, preenchido com seu respectivo meio suporte, recebeu $2 \times 10^{6}$ esporos/mL e a alimentação com água residuária sintética, contendo o fenol e glicose $(500 \mathrm{mg} / \mathrm{L})$, foi mantida em recirculação, durante 6 dias, para o estabelecimento do biofilme e aclimatação dos microrganismos.

Após este período, os reatores foram operados em regime de escoamento contínuo, sem recirculação do efluente, com água residuária "fresca".

\subsubsection{Microscopia}

No final da operação dos reatores de leito fixo, amostras dos meios suportes contendo biomassa foram preparadas e submetidas à análise microbiológica com o objetivo de confirmar a presença da espécie inicialmente inoculada.

Para facilitar a microscopia, a biomassa aderida em amostras dos meios suportes foi removida e diluída, em água destilada esterilizada $\left(120^{\circ} \mathrm{C}\right.$ a $\left.1 \mathrm{~atm}\right)$, a $10^{-1}, 10^{-2}$ e $10^{-3}$ e, em seguida, $1 \mathrm{~mL}$ de cada diluição foi colocado em placas de Petri contendo meio de cultura Sabouraud. As placas foram mantidas à temperatura ambiente $\left(27 \pm 1^{\circ} \mathrm{C}\right)$, durante o período de uma semana para verificação das colônias.

Alíquotas das diluições foram fixadas em lamínulas com ágar para a realização da microscopia de contraste de fases, utilizando microscópio LEICA de contraste de fases e fluorescência, acoplado à câmara com captura de imagem e software Pro-plus. 
As amostras dos meios suportes também foram observadas através de microscopia de varredura, realizada no Instituto de Física de São Carlos - USP, de acordo com os procedimentos relatados por Villena e Gutiérrez-Correa (2003).

\subsubsection{Métodos empregados para determinação das variáveis}

As variáveis determinadas durante a pesquisa e os métodos utilizados são mostrados na Tabela 4.4 .

Tabela 4.4: Variáveis determinadas e métodos utilizados.

\begin{tabular}{|c|c|c|}
\hline Variável & Etapa do Experimento & Método \\
\hline $\mathrm{DQO}$ & Caracterização, Batelada e Contínuo & Espectrofotométrico \\
\hline Fenol & Caracterização, Batelada e Contínuo & Cromatografia gasosa \\
\hline Glicose & Batelada e Contínuo & Espectrofotométrico \\
\hline $\mathrm{pH}$ & Caracterização, Batelada e Contínuo & Potenciométrico \\
\hline $\begin{array}{c}\text { Ácidos graxos } \\
\text { voláteis (AGV) }\end{array}$ & Contínuo & $\begin{array}{l}\text { Cromatografia gasosa } \\
\text { Determinação de }\end{array}$ \\
\hline $\begin{array}{l}\text { Nitrogênio } \\
\text { Amoniacal }\end{array}$ & Caracterização & $\begin{array}{l}\text { nitrogênio amoniacal - } \\
\text { análise de injeção de } \\
\text { fluxo (FIA) }\end{array}$ \\
\hline Nitrato & Caracterização & $\begin{array}{l}\text { Método da redução de } \\
\text { cádmio - análise de } \\
\text { injeção de fluxo (FIA) }\end{array}$ \\
\hline Fósforo & Caracterização & $\begin{array}{l}\text { Método da redução de } \\
\text { cádmio - análise de } \\
\text { injeção de fluxo (FIA) }\end{array}$ \\
\hline SSV & Batelada & Volatilização a $550^{\circ} \mathrm{C}$ \\
\hline OD & Contínuo & Oxímetro \\
\hline
\end{tabular}

A determinação das variáveis foi realizada conforme descrito em APHA (1998), exceto a de amônia, a qual foi realizada de acordo com Nóbrega et al. (1995).

$\mathrm{Na}$ quantificação da DQO foram utilizadas as amostras filtradas do afluente e efluente, através de filtro com poros de 1,2 $\mu \mathrm{m}$, diâmetro $47 \mathrm{~mm}$.

As análises de fenol foram realizadas por cromatografia gasosa (HP INNOWAX $30 \mathrm{~m}$ x 0,25 mm x 0,25 $\mu \mathrm{m}$ ), efetuadas de acordo com Bolaños et al. (2001), sob as seguintes condições:

○ cromatógrafo gasoso HP 6890/FI; 
○ Coluna HP INNOWAX - $30 \mathrm{~m}$ x 0,25 mm (diâmetro interno) x 0,25 $\mu \mathrm{m}$ de espessura de filme;

○ Temperatura do injetor de $250^{\circ} \mathrm{C}$;

○ Temperatura do detector de $300^{\circ} \mathrm{C}\left(\mathrm{H}_{2}=30 \mathrm{~mL} / \mathrm{min}\right.$, ar sintético de 300 $\mathrm{mL} / \mathrm{min}, \mathrm{N}_{2}$ de $33 \mathrm{~mL} / \mathrm{min}$. Range = 1);

$\circ$ Temperatura do forno de $100^{\circ} \mathrm{C}(3 \mathrm{~min}), 180^{\circ} \mathrm{C}(15 \mathrm{~min})$ e $5^{\circ} \mathrm{C}(1 \mathrm{~min})$, com fluxo de arraste de $\mathrm{H}_{2}$ de $2 \mathrm{~mL} / \mathrm{min}$.

O limite de detecção do método empregado para quantificação de fenol foi de 0,50 mg/L e de AGV de 0,8 mg/L.

Nas análises de nitrogênio amoniacal, nitrato e fósforo, determinadas por FIA (Análise de Injeção de Fluxo), foram empregados os reagentes mostrados na Tabela 4.5.

A concentração de glicose foi medida com uso de kit da marca Laborlab para determinação de glicose, com leitura em espectrofotômetro no comprimento de onda de $505 \mathrm{~nm}$.

Tabela 4.5: Reagentes empregados para determinação das concentrações de amônia, nitrato e fósforo, realizada por FIA.

\begin{tabular}{cc}
\hline Variável & Reagentes \\
\hline Nitrogênio amoniacal & $\begin{array}{c}\text { Ácido salicílico, citrato de sódio, nitroprusiato } \\
\text { de sódio, hidróxido de sódio e hipoclorito de } \\
\text { sódio. }\end{array}$ \\
Nitrato & $\begin{array}{c}\text { Sulfanilamida, naftil etileno diamina, cádmio e } \\
\text { sulfato de cobre. }\end{array}$ \\
Fósforo & Ácido Ascórbico \\
\hline
\end{tabular}

\subsubsection{Determinação do fenol adsorvido e armazenado}

A concentração de fenol adsorvido nas paredes da biomassa fúngica, bem como de fenol armazenados nos vacúolos das células fungos foi determinada a partir de volumes conhecidos de amostras de cada reator, separando-se o micélio por centrifugação em tubos "racker". Em seguida, o sobrenadante foi descartado e à massa úmida adicionouse $1,0 \mathrm{~mL}$ de solução de $\mathrm{NaOH}(1 \mathrm{~mol} / \mathrm{L})$. A mistura foi submetida a ultra-som durante 
30 minutos para extração do fenol adsorvido. Após este período, nova centrifugação permitiu a separação da solução alcalina contendo fenolato de sódio do micélio. A solução foi acidificada pela adição de $1,0 \mathrm{~mL}$ de solução $1 \mathrm{~mol} / \mathrm{L}$ de $\mathrm{H}_{2} \mathrm{SO}_{4}$ e preparada para análise cromatográfica. A concentração de fenol adsorvido por grama de massa fúngica foi determinada a partir da concentração relativa ao volume da amostra de $2 \mathrm{~mL}$ devidamente padronizada em função do fator de diluição $(2: 1000)$ e da biomassa pesada. 


\section{RESULTADOS E DISCUSSÃO}

\subsection{Batelada}

O preparo da água residuária sintética, em cada reator, resultou em diferentes concentrações iniciais de matéria orgânica, medida como DQO, e fenol, porém a concentração média de matéria orgânica foi de $715 \pm 25 \mathrm{mg}$.DQO/L, nos reatores de controle $(\mathrm{RC})$ e nos reatores com fungo $(\mathrm{RF})$, e de $6058 \pm 150 \mathrm{mg} . \mathrm{DQO} / \mathrm{L}$, nos reatores com fungos e glicose. A concentração média de fenol nos reatores foi de $323 \pm 22 \mathrm{mg} / \mathrm{L}$.

Nas Figuras 5.1 e 5.2, são observadas, respectivamente, as remoções de matéria orgânica, medida em DQO, e fenol nos reatores RC, RF e RFG.

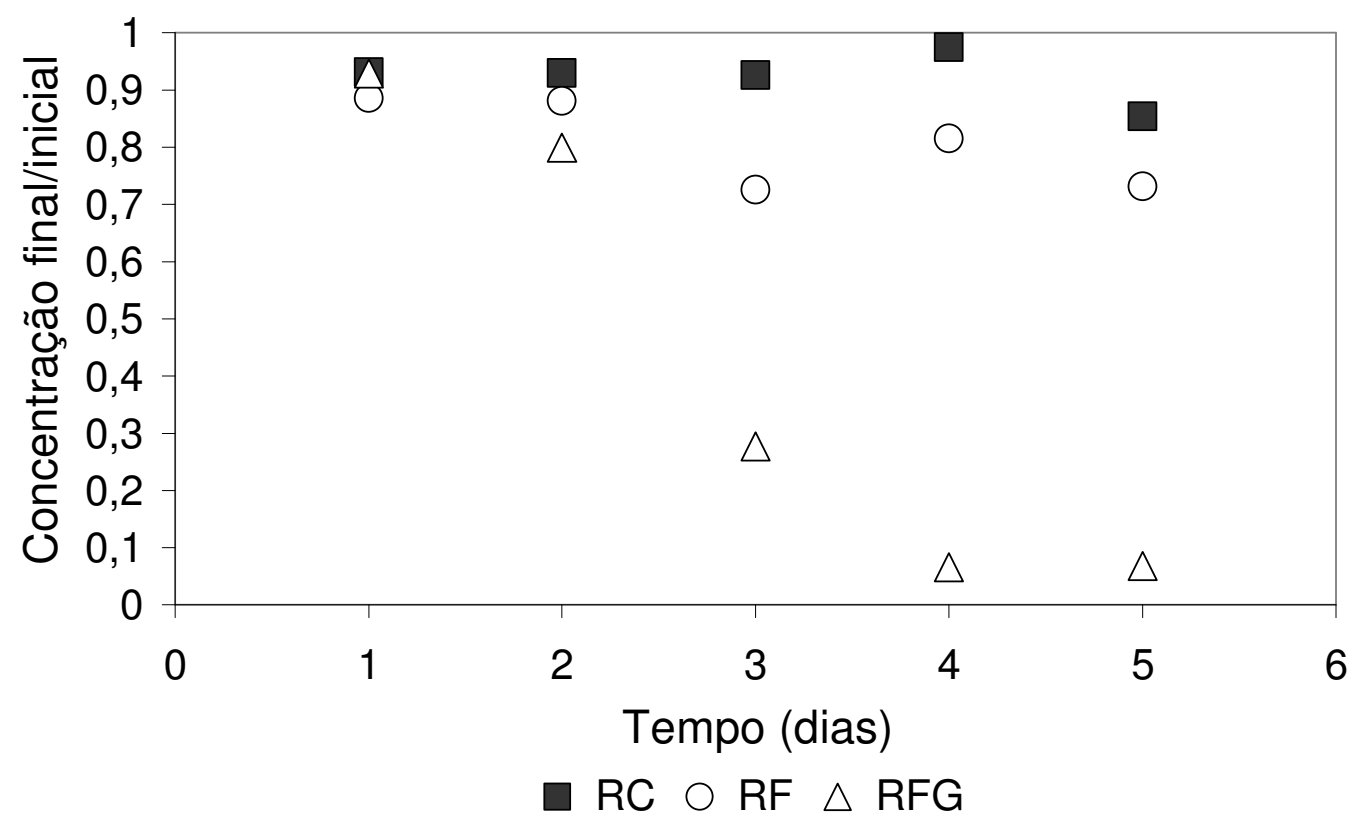

Figura 5.1: Remoção de matéria orgânica, expressa em DQO, nos reatores de controle (RC), com fungos (RF) e com fungos e glicose (RFG), ao longo da batelada. 


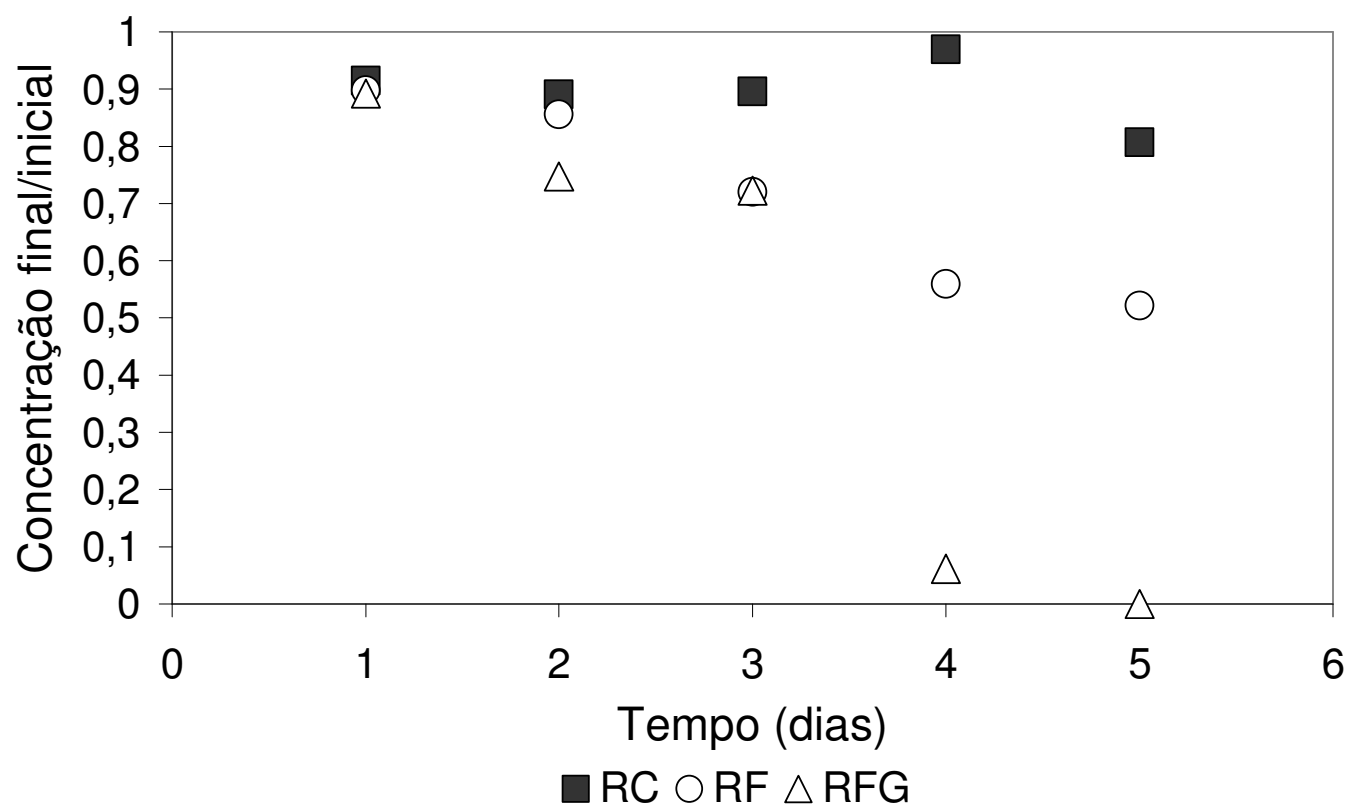

Figura 5.2: Remoção de fenol nos reatores de controle (RC), com fungos (RF) e com fungos e glicose (RFG), ao longo da batelada.

O uso de glicose favoreceu a obtenção de maiores reduções da concentração de fenol e de matéria orgânica. Nos reatores RFG, no último dia do experimento, a concentração do poluente era inferior a $1 \mathrm{mg} / \mathrm{L}$, concentração mínima detectável pelo método, tendo-se obtido 93\% de redução de matéria orgânica, medida em DQO.

Nos reatores de controle (RC), a eficiência de remoção do poluente não foi significativa em relação aos reatores com fungos. O percentual máximo de redução de fenol nos reatores RC foi de $19 \%$ e o de matéria orgânica foi de $15 \%$, ambos no $5^{\circ}$ dia. Em virtude de os reatores terem sido vedados e protegidos da ação da luz, a remoção de fenol não foi atribuída à volatilização e nem a processo de fotodecomposição. Por outro lado, embora não se tenha detectado visualmente a presença de micélio, não se pode afirmar ou não a existência de microrganismos contaminantes, uma vez que não foram realizadas análises microscópicas nesses reatores.

Nos reatores RF, os maiores percentuais de redução de fenol (48\%) e de matéria orgânica (27\%), expressa em DQO, foram obtidos no quinto dia e, curiosamente, a eficiência de remoção de fenol foi superior a de matéria orgânica, na maior parte do experimento, o que pode indicar a presença de substâncias produzidas pelos fungos, as quais não puderam ser detectadas. 
A degradação aeróbia de fenol envolve etapas nas quais os compostos intermediários são formados para posterior assimilação como ácido mucônico e 2hidroximucônico (van SCHIE e YOUNG, 2000). A água residuária empregada, sem a presença de fenol e glicose, era uma mistura de água de torneira e sais, com concentração de matéria orgânica de $4 \mathrm{mg}$ DQO/L, de modo que o fenol ao ser utilizado pelos microrganismos, seria transformado em material celular e em novas substâncias.

O uso de glicose favoreceu a assimilação do fenol pelos fungos que aumentou gradativamente ao longo do tempo, até alcançar $100 \%$ de remoção, no $5^{\circ}$ dia (Figura 5.3). Segundo Vinciguerra et al. (1995), o emprego de substrato primário no tratamento de efluentes é de grande importância, pois melhora a degradação do poluente, o que foi observado com a obtenção dos maiores percentuais de degradação pelos reatores.

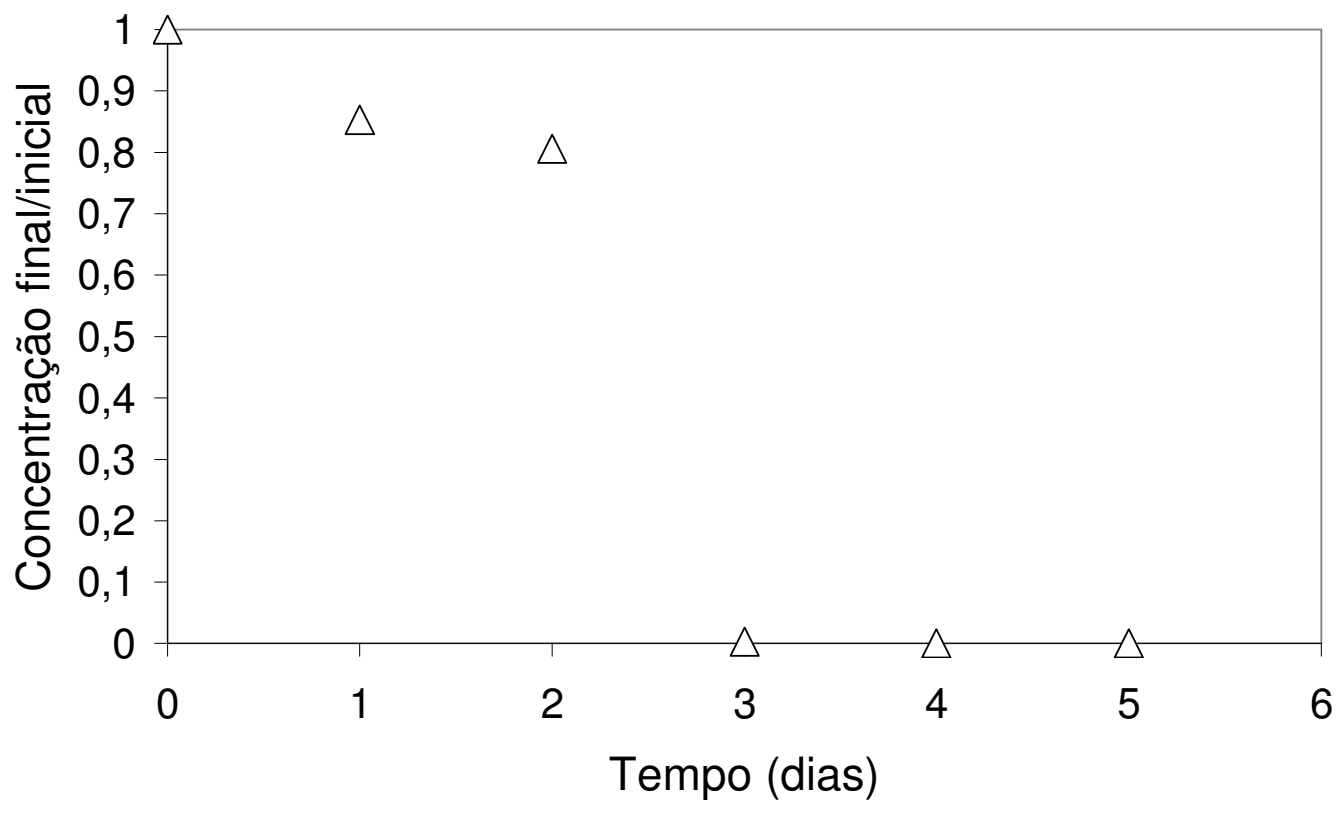

Figura 5.3: Remoção de glicose nos reatores com fungos e glicose (RFG), ao longo da batelada.

Nos reatores RFG, a glicose foi utilizada pelos fungos até o terceiro dia, quando se registrou $99 \%$ de remoção, e, após não ser mais detectada na água residuária, foram alcançadas maiores remoções de fenol, uma vez que os fungos, a partir deste dia, passaram a utilizar exclusivamente o fenol como fonte de carbono. 
Nas Figuras 5.4a e 5.4b é mostrada a normalização das concentrações de fenol para os reatores com glicose $(\mathrm{RFG})$ e sem glicose $(\mathrm{RF})$. A partir da relação $\mathrm{C} / \mathrm{C}_{\mathrm{o}}$ foram obtidas as velocidades de consumo $\left(\mathrm{r}_{\mathrm{s}}\right)$ em função do tempo (t) (Figuras 5.5a e 5.5b). Observou-se que os reatores RFG apresentaram maiores velocidades de consumo de fenol, de modo que a presença de glicose acelerou sua remoção da água residuária.
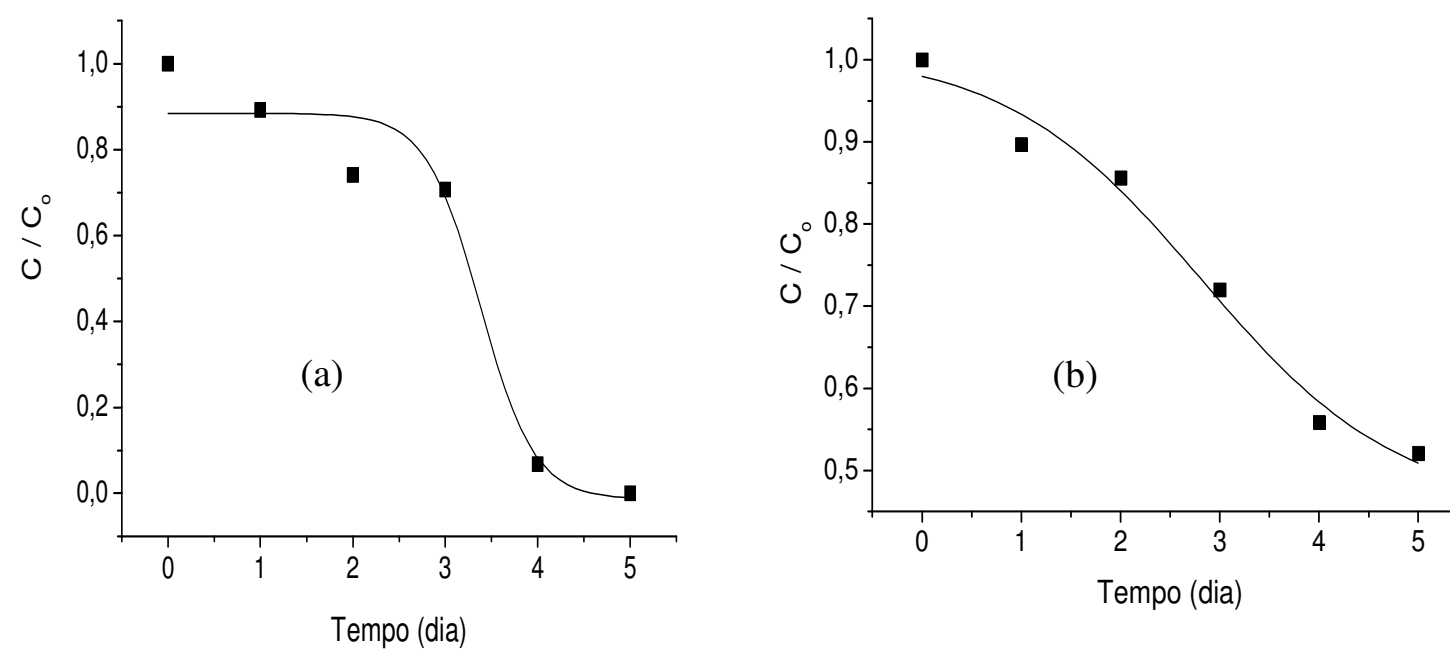

Figura 5.4: Ajuste das concentrações normalizadas de fenol obtidas nos reatores com fungos e glicose (RFG) (a) e com fungos sem glicose (RF) (b), ao longo da batelada.
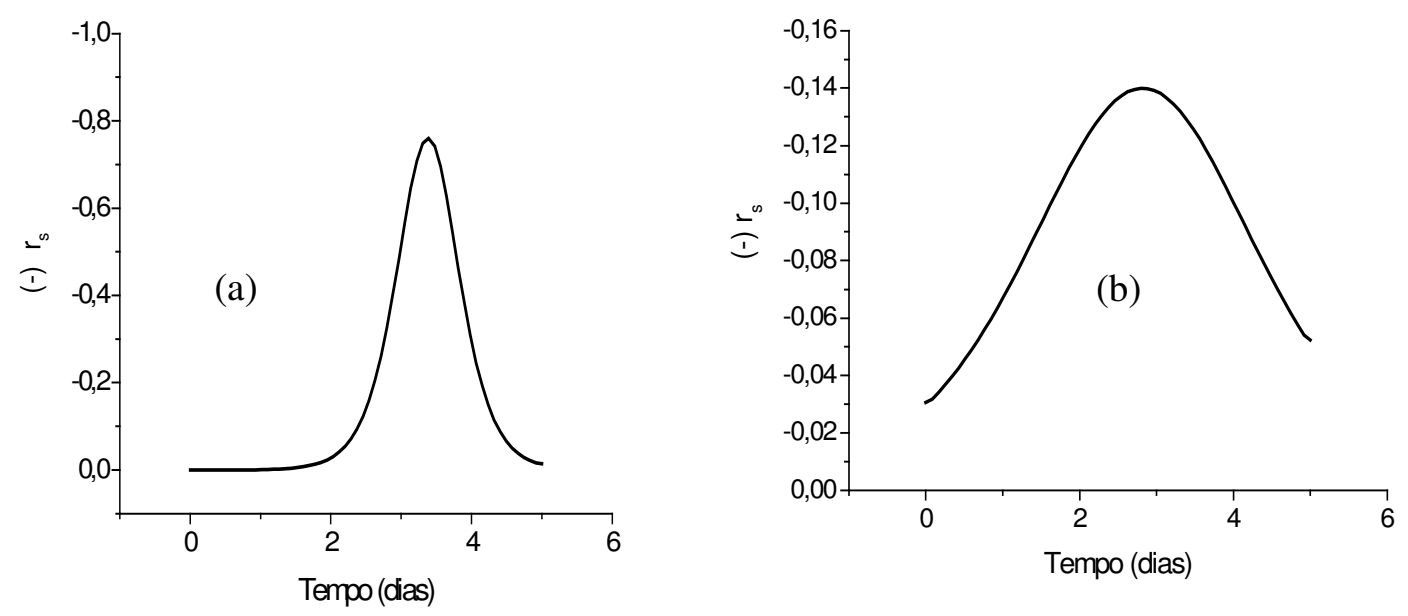

Figura 5.5: Variação da velocidade de consumo de fenol durante o ensaio em batelada nos reatores com fungos e glicose (RFG) (a) e com fungos (RF) (b). 
Nos reatores com fungos (RF), foram obtidas velocidades média e máxima de consumo de fenol de $0,094 \mathrm{~d}^{-1}$ e $0,14 \mathrm{~d}^{-1}$, enquanto que, nos reatores com fungos e glicose (RFG), foi alcançada a velocidade média de $0,18 \mathrm{~d}^{-1}$, sendo a máxima de $0,76 \mathrm{~d}^{-1}$. Portanto, nos reatores contendo glicose, a velocidade máxima de consumo de fenol foi 5,4 vezes maior que nos reatores que não tinham glicose (RF). Da mesma forma, a velocidade média de consumo nos reatores RFG foi, aproximadamente, duas vezes maior que nos reatores RF.

Neste trabalho, tanto nos reatores com fungos e água residuária com glicose (RFG), quanto nos que continham fungos e água residuária sem glicose (RF), houve remoção gradual do poluente ao longo de todo o experimento.

Além disso, de acordo com a Tabela 5.1, dados inerentes à concentração de fenol adsorvido à biomassa fúngica, que cresceu no interior dos reatores RF e RFG, mostram que a adsorção foi pouco relevante, mostrando também que o mecanismo de adsorção teve pouca influência na remoção global do poluente da água residuária e não esteve relacionado ao emprego de glicose.

A baixa concentração de fenol não assimilado (fenol adsorvido + armazenado) pelos fungos ocorreu porque em células vivas, os fungos o mecanismo de assimilação é superior ao de adsorção, o qual é pouco relevante em células vivas. A adsorção do composto nas paredes da célula fúngica ocorre em grande intensidade apenas no caso de células mortas, conforme relatado por Rao e Viraraghavan (2002), devido à fatores físicos e químicos. Segundo GOYAL et al. (2003), a adsorção de compostos em células mortas é influenciada pelo $\mathrm{pH}$ e pelas propriedades da superfície do microrganismo, concentração do poluente e temperatura.

Assim, como neste experimento as células fúngicas estavam vivas, a maior parcela de fenol disponível foi utilizada pelos fungos como fonte de matéria e energia, restando uma concentração de fenol muito baixa no meio, a qual foi armazenada nos vacúolos dos fungos, e também adasorvida na superfície do micélio.

Paralelamente ao consumo de fenol, observou-se crescimento de biomassa, medida pela concentração de sólidos voláteis em suspensão (SSV), nos reatores RFG. O crescimento máximo foi alcançado no quarto dia, após o qual houve diminuição de biomassa, provavelmente devido à exaustão de nutrientes no meio. Nesses reatores, a biomassa apresentava-se sob a forma de "pellets", pequenas esferas aglutinadas, devido 
ao estímulo da produção de polissacarídeos pelo uso de glicose, pois de acordo com Carlile e Watkinson (1994), os fungos produzem compostos extracelulares que lhes conferem capacidade de aderência, o que permitiu a agregação na forma de "pellets", sendo a glicose essencial, como fonte de carbono facilmente assimilada, ajudando na produção de moléculas como polissacarídeos, proteínas e lipídios, outros compostos que também favorecem o acúmulo do peso seco (COSTA et al., 2004).

Tabela 5.1: Concentração de fenol adsorvido no micélio presente nos reatores com fungos (RF) e com fungos e glicose (RFG).

\begin{tabular}{ccccc}
\hline Reatores & $\begin{array}{c}\text { Remoção de fenol } \\
\text { da água residuária } \\
(\boldsymbol{\%})\end{array}$ & $\begin{array}{c}\text { mg de } \\
\text { Fenol / g de } \\
\text { biomassa }\end{array}$ & $\begin{array}{c}\text { Fenol } \\
\text { adsorvido } \\
(\boldsymbol{\%})\end{array}$ & $\begin{array}{c}\text { Fenol } \\
\text { assimilado } \\
(\boldsymbol{\%})\end{array}$ \\
\hline $\mathrm{RF}_{1}$ & 10,2 & 1,4 & 0,5 & 9,7 \\
$\mathrm{RF}_{2}$ & 14,4 & 0,4 & 0,1 & 14,3 \\
$\mathrm{RF}_{3}$ & 28 & 0,8 & 0,2 & 27,8 \\
$\mathrm{RF}_{4}$ & 44 & 0,6 & 0,2 & 43,8 \\
$\mathrm{RF}_{5}$ & 48 & 0 & 0 & 48 \\
$\mathrm{RFG}_{1}$ & 10,6 & 1,7 & 0,6 & 10 \\
$\mathrm{RFG}_{2}$ & 25,4 & 0,2 & 0,1 & 25,3 \\
$\mathrm{RFG}_{3}$ & 28 & 0,2 & 0,1 & 27,7 \\
$\mathrm{RFG}_{4}$ & 94 & 0 & 0 & 94 \\
$\mathrm{RFG}_{5}$ & 100 & 0 & 0 & 100 \\
\hline
\end{tabular}

Nos reatores RF, a biomassa encontrava-se "fragmentada" e dispersa no meio líquido (crescimento filamentoso). A biomassa medida nos reatores RF foi muito inferior ao observado nos reatores RFG (9 a $127 \mathrm{mg}$ SSV/L), com valores de 1 a $6 \mathrm{mg} \mathrm{SSV/L}$. Similarmente, Rodrigues et al. (2004) obtiveram, em experimento em batelada, biomassa aglutinada de Aspergillus niger e Fusarium sp. ao utilizarem água residuária sintética semelhante à empregada nessa pesquisa, em reatores em batelada, sob condições de temperatura não controlada e agitação por meio de aeradores de aquário.

Não houve crescimento visual de biomassa no interior dos reatores de controle $(\mathrm{RC})$.

Portanto, a glicose proporcionou aos fungos melhores condições para o crescimento, promovendo uma adaptação dos microrganismos ao fenol, resultando em maior crescimento de biomassa e, conseqüentemente, melhor eficiência de remoção de fenol e DQO da água residuária sintética empregada. 
Na Figura 5.6 é apresentada a variação do pH nos reatores ao longo da batelada. Houve diminuição do $\mathrm{pH}$ em todos os reatores estudados, contudo os menores valores de $\mathrm{pH}$ ocorreram nos reatores RFG devido à maior produção de ácidos orgânicos, a partir do consumo de glicose, conforme relatado por Assas et al. (2002).

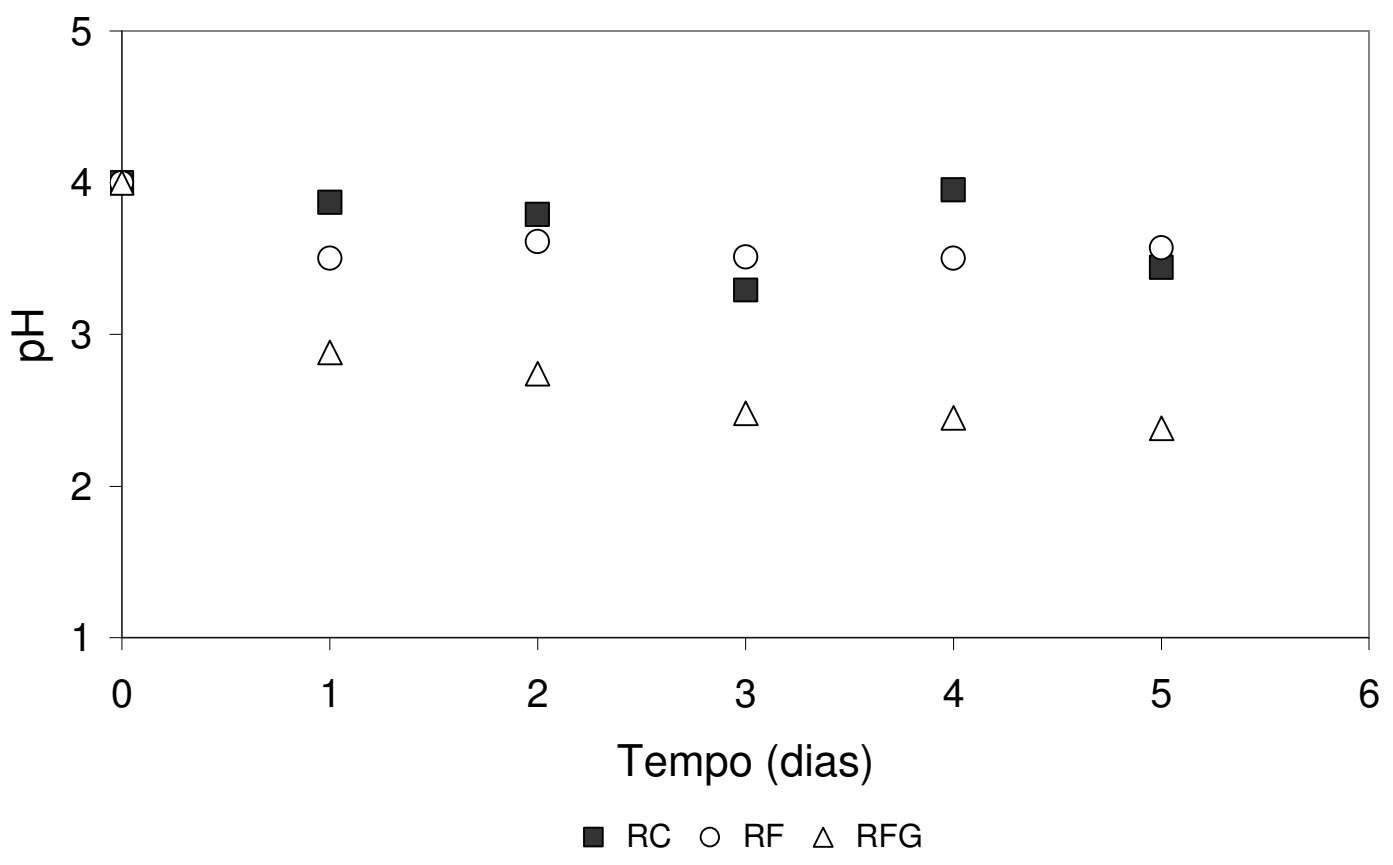

Figura 5.6: Variação do $\mathrm{pH}$ nos reatores de controle (RC), com fungos (RF) e com fungos e glicose (RFG).

Assas et al. (2002) obtiveram resultados semelhantes quando da utilização de Geotrichum candidum para o tratamento do efluente da indústria de azeite de oliva e a diminuição do pH foi atribuída à geração de ácidos orgânicos. Da mesma forma, Rodrigues et al. (2004) ao empregarem água residuária sintética com fenol em reatores com Aspergillus niger e Fusarium sp. observaram redução inicial nos valores de pH, sendo que nos reatores que continham glicose a diminuição nos valores de $\mathrm{pH}$ foi mais rápida em relação aos demais reatores, como reflexo da atividade microbiana mais intensa.

De acordo com Kyriacou et al. (2005), a atividade microbiana pode ser diretamente relacionada com a quantidade de biomassa. A concentração de microrganismos dentro do reator é um fator importante no tratamento da água residuária, sendo que, respeitando aspectos relacionados à limitação de difusão de 
substrato, quanto maior a população microbiana, maior será a eficiência de remoção do poluente para uma dada concentração, pois à medida que a população aumenta, há menor disponibilidade de alimento para os microrganismos e, conseqüentemente, melhor polimento da água residuária.

Ainda segundo esses autores, menores valores de $\mathrm{pH}$ são alcançados como resultado da atividade metabólica do Aspergillus niger. Maior produção de biomassa de A. niger foi obtida por O'Donnell et al. (2001) em pH $3(5,1 \mathrm{~g}$ de biomassa/L), registrando-se valores menores em pH 7 (1,9 g de biomassa/L), fora da faixa ótima de $\mathrm{pH}$ para o crescimento da espécie, ao investigar o efeito do controle do $\mathrm{pH}$ sobre a atividade de enzimas proteases.

Neste trabalho, observou-se que o $\mathrm{pH}$ diminuiu até o $4^{\mathrm{o}}$ dia de batelada, quando o crescimento da biomassa atingiu o valor máximo, passando a apresentar início de fase endógena no último dia, como conseqüência da exaustão de nutrientes no meio. No final do experimento, o pH manteve-se constante em relação ao dia anterior, com valores em torno de 2,4, indicando que os ácidos orgânicos produzidos no meio, pelos fungos, ainda não teriam sido consumidos, pois com o consumo dos ácidos gerados, o pH tende a subir, voltando a valor próximo do inicial (FADIL et al., 2003; KYRIACOU et al., 2005).

Assim, a presença de glicose influenciou no aumento da concentração de biomassa no interior dos reatores RFG, evidenciada pelo aumento de SSV, e, conseqüentemente, a produção de ácidos orgânicos foi maior nesses reatores, nos quais foram registrados os menores valores de $\mathrm{pH}$, como medida de atividade microbiana mais intensa (FADIL et al., 2003).

A microscopia mostrou que Aspergillus niger foi a espécie de fungo presente no meio. Algumas das estruturas do Aspergillus niger apresentaram deformações como aparente ausência de filíades, estruturas que guardam os esporos, no final da batelada, possivelmente, devido ao efeito tóxico do fenol (Figura 5.7a, 5.7b e 5.7c). 


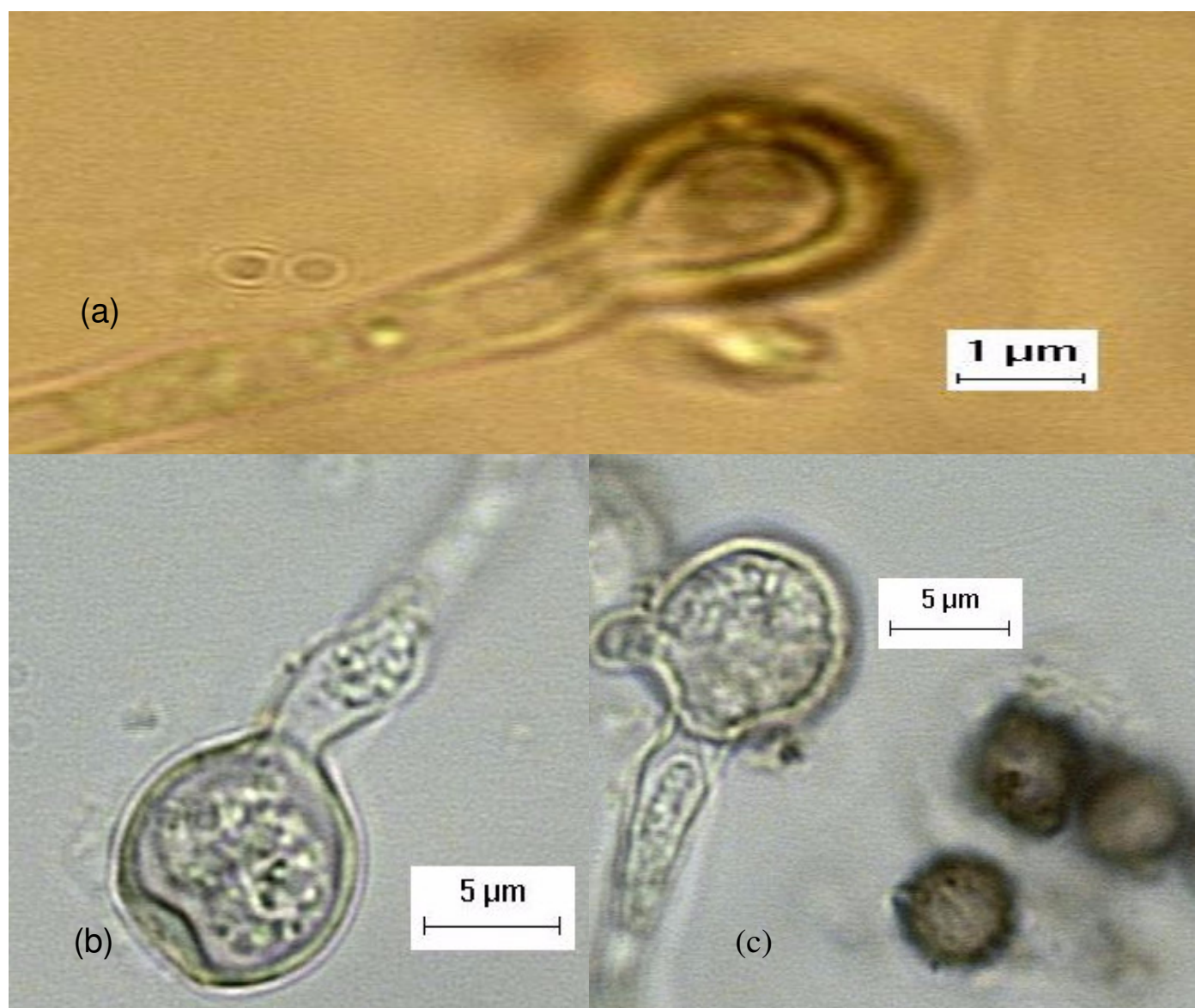

Figura 5.7: Microscopia da biomassa no interior dos reatores: (a) RF desmontado no segundo dia da batelada - estrutura vesicular, de onde partem os esporos; (b) e (c) detalhe do Aspergillus niger nos reatores RFG desmontados no quinto dia. 


\subsection{Operação dos Reatores Contínuos de Leito Fixo}

\subsubsection{Caracterização da Água Residuária Sintética}

A água residuária sintética empregada nesta pesquisa possuía as características apresentadas na Tabela 5.2.

Tabela 5.2: Características da água residuária sintética com fenol

\begin{tabular}{cc}
\hline VARIÁVEL & CONCENTRAÇÃO \\
\hline $\mathrm{DQO}_{\mathrm{g}}{ }^{1}$ & $1139 \mathrm{mg} / \mathrm{L}$ \\
$\mathrm{DQO}$ & $623 \mathrm{mg} / \mathrm{L}$ \\
$\mathrm{N}-\mathrm{NH}_{4}$ & $363 \mathrm{mg} / \mathrm{L}$ \\
$\mathrm{N}-\mathrm{NO}_{3}$ & $146 \mathrm{mg} / \mathrm{L}$ \\
$\mathrm{P}-\mathrm{PO}_{4}$ & $40 \mathrm{mg} / \mathrm{L}$ \\
$\mathrm{pH}$ & 6,0 \\
\hline${ }^{1} \mathrm{DQO}$ da água residuária com fenol e glicose
\end{tabular}

\subsubsection{Germinação dos esporos}

Cada reator contínuo, $\mathrm{R}_{1}$ (com meio suporte de manta de polipropileno) e $\mathrm{R}_{2}$ (com meio suporte de espuma de poliuretano), recebeu o inóculo de Aspergillus niger e, após três dias, foi verificada visualmente a presença de pequenas estruturas disformes e gelatinosas, aderidas às paredes dos reatores e aos meios suportes e, principalmente, na entrada de ar.

Visualmente, o reator $R_{1}$ apresentou uma distribuição mais homogênea de microrganismos aderidos ao meio suporte que o reator $\mathrm{R}_{2}$, ou seja, a manta empregada como meio suporte em $\mathrm{R}_{1}$ foi totalmente colonizada pelos microrganismos ao longo do reator, enquanto que em $\mathrm{R}_{2}$, o crescimento ocorreu, principalmente, nos primeiros $0,4 \mathrm{~m}$ da altura total do reator, a partir da tubulação de entrada de alimentação. Nas Figuras 5.8 (a) e 5.8 (b) são mostrados reatores $R_{1}$ e $R_{2}$ com biofilmes aderidos aos meios suportes. 


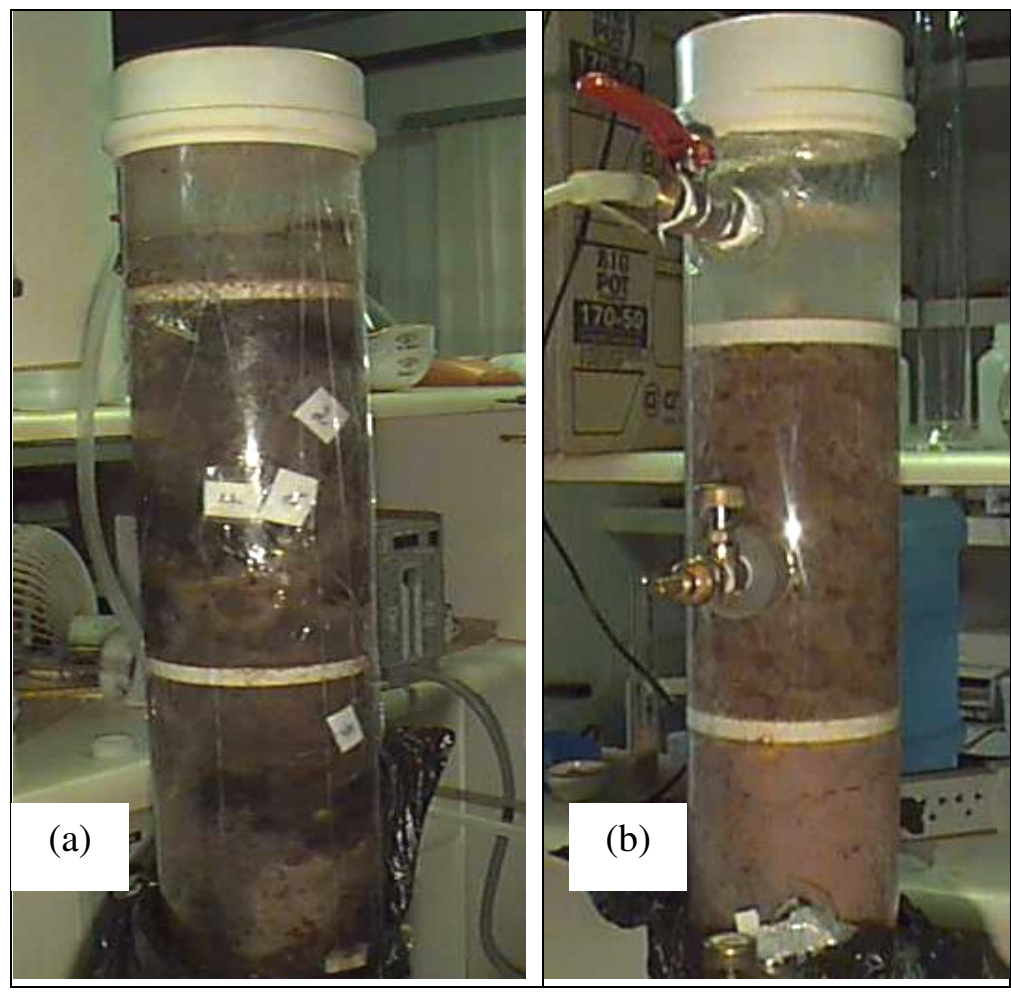

Figura 5.8: Reatores com biofilme aderido ao meio suporte de $R_{1}$ (a) - manta de polipropileno - e $\mathrm{R}_{2}$ (b) - espuma de poliuretano.

\subsubsection{Operação dos reatores com TDH de $8 \mathrm{~h}$ - alimentação com glicose (Fase I)}

Nas Figuras 5.9 e 5.10 são apresentadas as variações de matéria orgânica, medida em termos de DQO, para os reatores $\mathrm{R}_{1}$ e $\mathrm{R}_{2}$, durante esta fase de monitoramento, sendo as variações da eficiência de remoção, mostradas e nas Figuras 5.11 e 5.12.

Os reatores apresentaram desempenhos similares quanto à remoção de DQO solúvel. Os percentuais de remoção alcançaram, em média, $93 \% \pm 4$ e $92 \% \pm 6$, respectivamente, nos reatores $R_{1}$ e $R_{2}$. Com relação à remoção de matéria orgânica no efluente bruto, em ambos os reatores, as remoções médias foram de $88 \% \pm 5$, obtidos nos efluentes filtrados dos reatores, o que ocorreu devido à presença de fragmentos do biofilme nos efluentes brutos. 


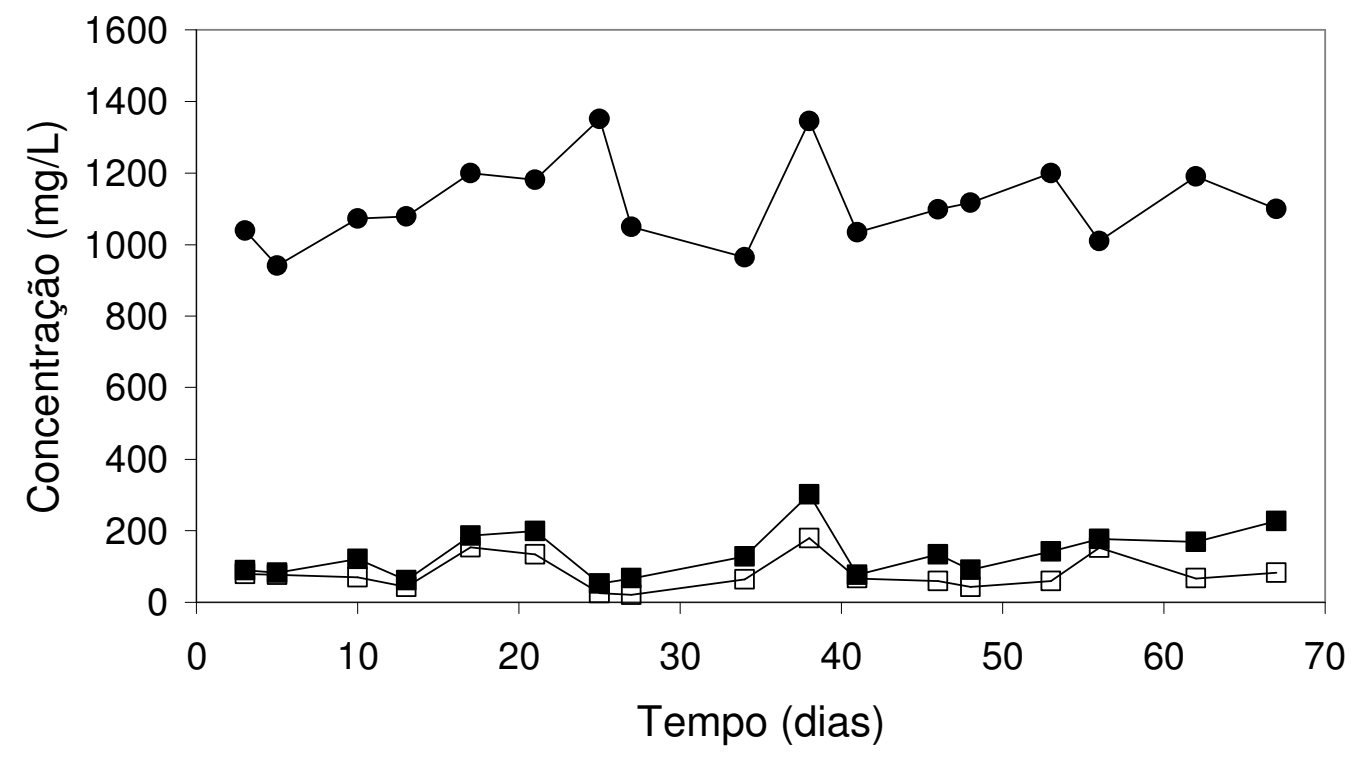

- Afluente - Efluente Bruto $\square$ Efluente Filtrado

Figura 5.9: Variações das concentrações de matéria orgânica, medida em DQO, no afluente e efluente do reator com meio suporte de manta de polipropileno $\left(\mathrm{R}_{1}\right)$, no TDH de 8 h, na Fase I (alimentação com glicose).

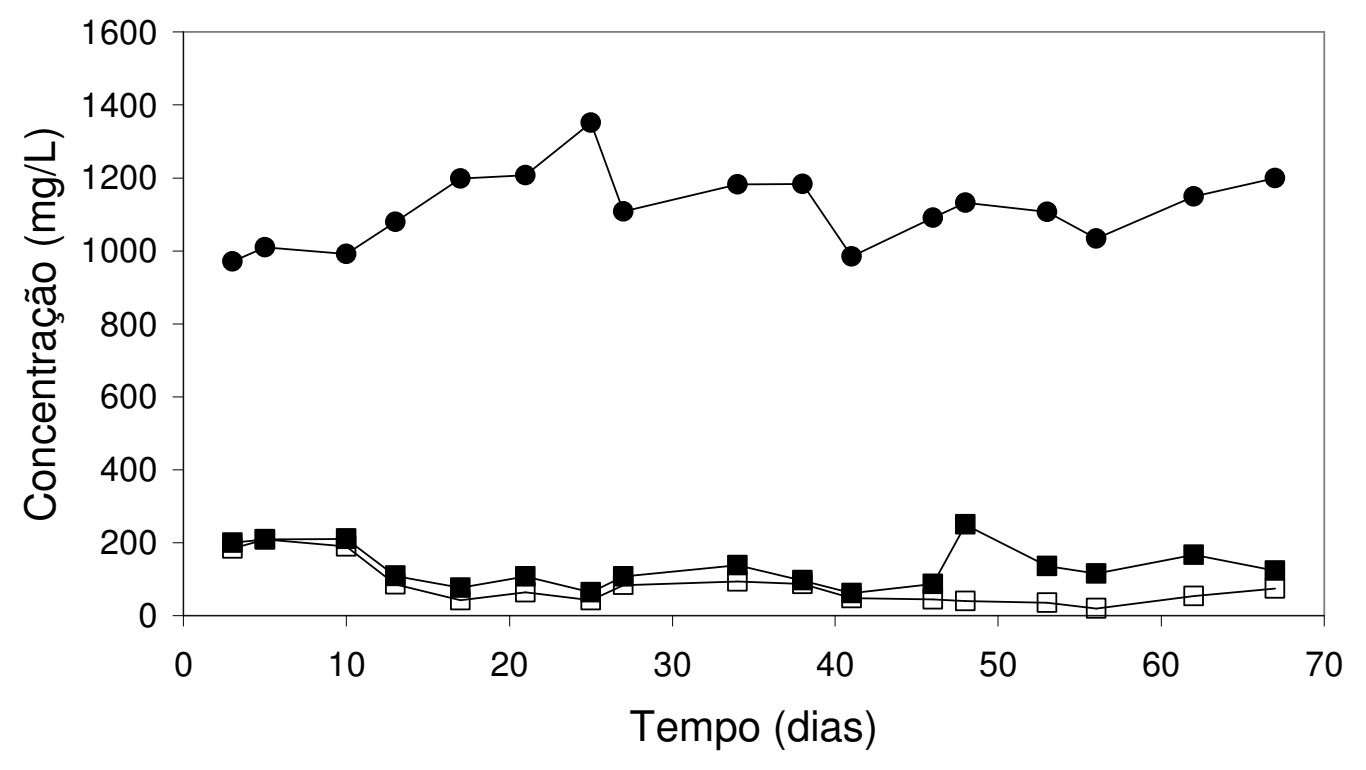

- Afluente - Efluente Bruto $\square$ Efluente Filtrado

Figura 5.10: Variações das concentrações de matéria orgânica, medida em DQO, no afluente e efluente do reator com meio suporte de espuma de poliuretano $\left(\mathrm{R}_{2}\right)$, com TDH de 8 h, na Fase I (alimentação com glicose). 


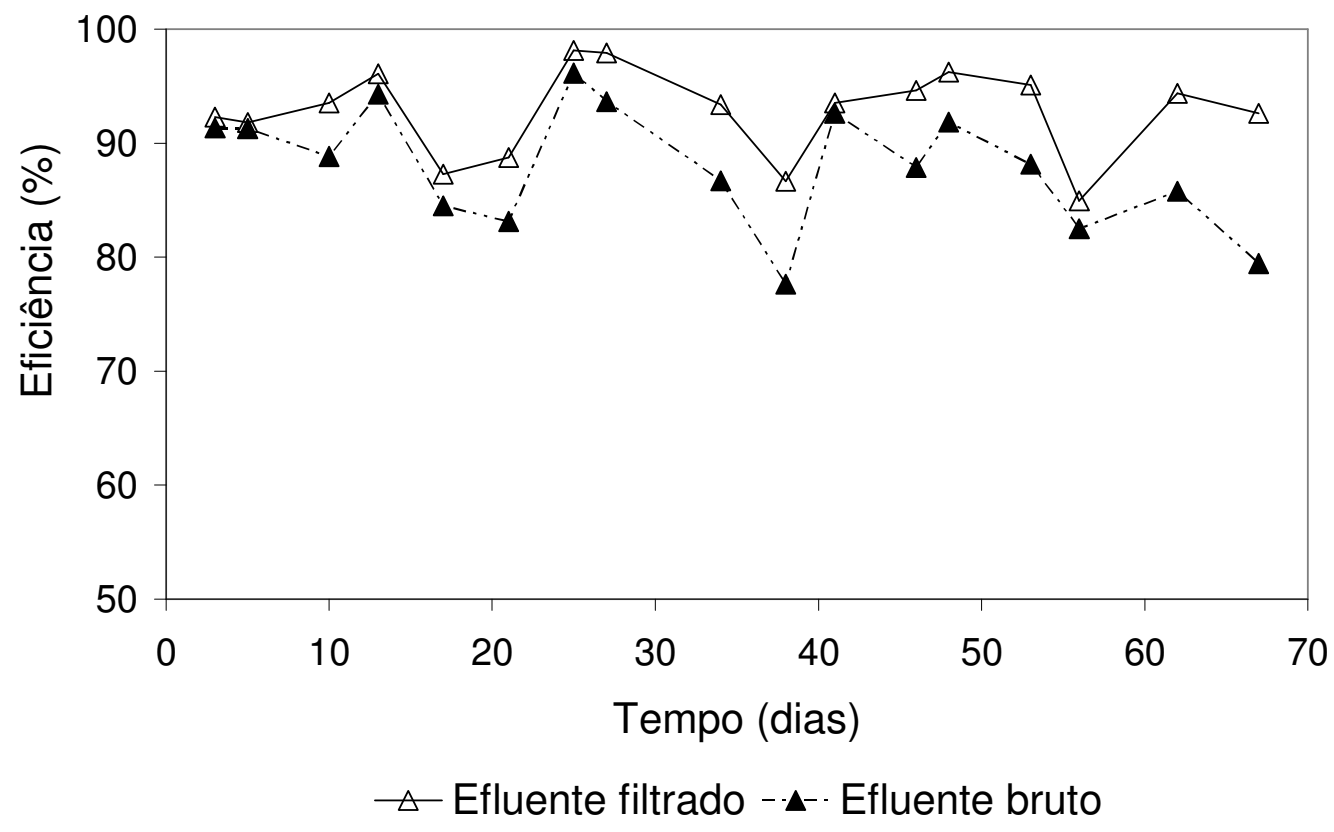

Figura 5.11: Variações das eficiências de remoção de matéria orgânica, medida em DQO, no afluente e efluente do reator com meio suporte de manta de polipropileno $\left(\mathrm{R}_{1}\right)$, no TDH de 8 h, na Fase I (alimentação com glicose).

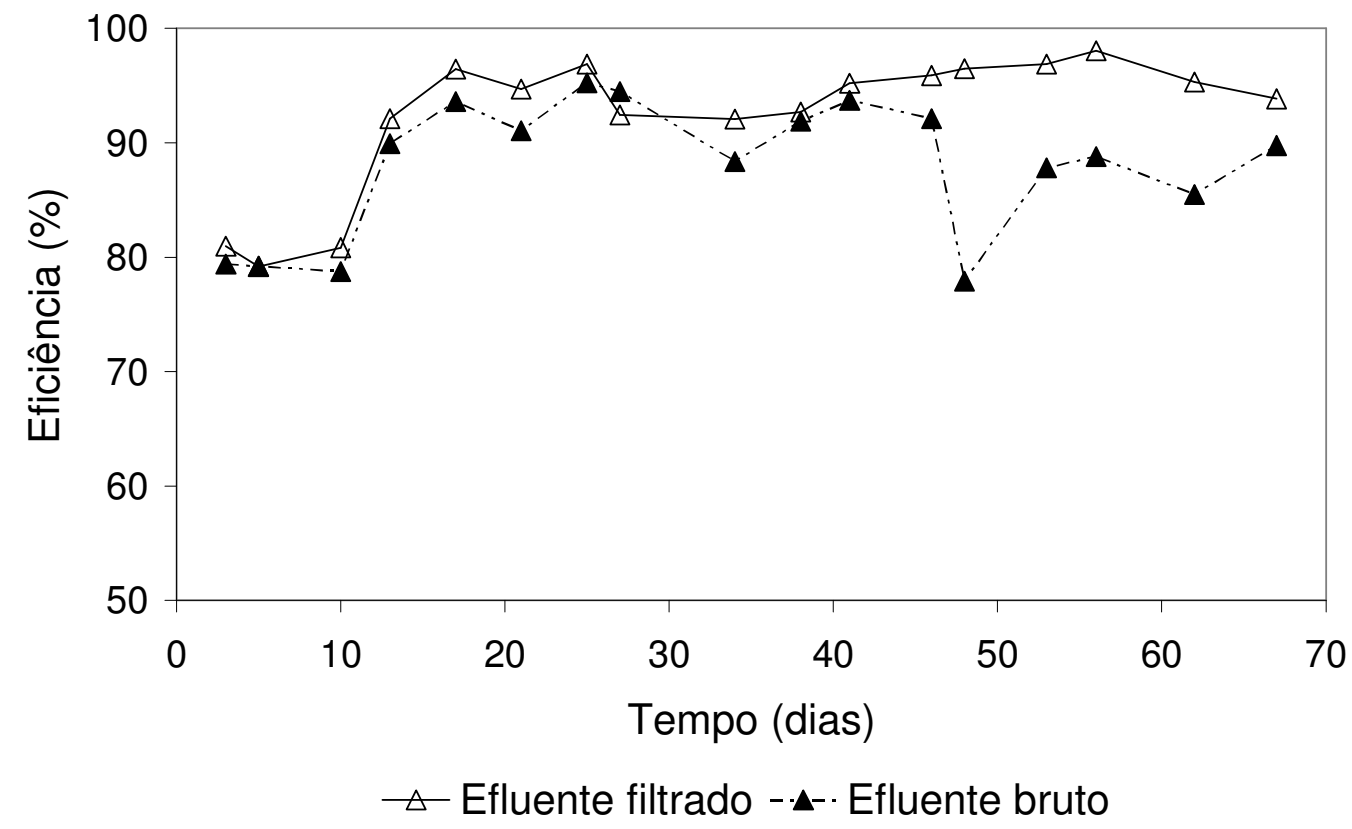

Figura 5.12: Variações das eficiências de remoção de matéria orgânica, medida em DQO, no afluente e efluente do reator com meio suporte de espuma de poliuretano $\left(R_{2}\right)$, no TDH de 8 h, na Fase I (alimentação com glicose). 
Tanto no reator com meio suporte de manta de polipropileno $\left(\mathrm{R}_{1}\right)$ quanto no reator com meio suporte de espuma de poliuretano $\left(\mathrm{R}_{2}\right)$, a maior remoção de matéria orgânica, em DQO, no efluente filtrado, foi de $98 \%$, ocorrendo nos $25^{\circ}$ e $27^{\circ}$ dias, em $\mathrm{R}_{1}$, e no $56^{\circ}$ dia de operação em $\mathrm{R}_{2}$. As menores eficiências de remoção de matéria orgânica nesses reatores foram de $85 \%\left(\mathrm{R}_{1}\right)$ e $79 \%\left(\mathrm{R}_{2}\right)$, sendo importante ressaltar que, ao longo do período de operação, a eficiência de remoção de matéria orgânica apresentou valores superiores ao mínimo e, particularmente, no reator $\mathrm{R}_{2}$, as menores remoções ocorreram nos primeiros dias de operação (até o $10^{0}$ dia), no estágio inicial de formação do biofilme e adaptação dos microrganismos à água residuária.

Particularmente, no reator $\mathrm{R}_{1}$, observou-se que em algumas coletas $\left(17^{\circ}, 21^{\circ}, 38^{\circ}\right.$ e $56^{\circ}$ dias de operação), o efluente apresentou DQO solúvel relativamente elevada em comparação com os demais dias. Os valores mais elevados da DQO, no efluente filtrado, podem ser relacionados à substâncias excretadas no meio pelos microrganismos, as quais não foram determinadas, pois nestes dias a concentração de fenol no efluente era baixa, menor que $0,8 \mathrm{mg} / \mathrm{L}$, indicando seu consumo pelos microrganismos, de modo que metabólitos oriundos do processo de assimilação foram excretados no meio.

A excreção de metabólitos durante a síntese de produção de biomassa é relatada por Witteveen (1993). Segundo o autor, a fonte de carbono disponível, ao ser utilizada pelos fungos na síntese de biomassa, produz energia e metabólitos que podem ser acumulados no interior da célula ou excretados.

Desta forma, a excreção de metabólitos é a o resultado das reações de síntese na assimilação do substrato, como também observado por Souza et al. (2005). Os autores relataram que ao utilizar Aspergillus 1AAL1 no tratamento de água residuária de indústria de nitrocelulose, houve aumento da medida de cor ao longo de experimento em batelada (168 h), atribuindo esse aumento a substâncias excretadas no meio pelos fungos, relacionadas anabolismo a partir do uso de fenóis.

A remoção de fenol é mostrada nas Figuras 5.13 e 5.14. O efluente apresentou, na maioria do período de monitoramento, percentual de remoção de fenol de, aproximadamente, $100 \%$, sendo as remoções médias de $99,5 \% \pm 2$ e $98 \% \pm 5$, respectivamente,em $R_{1}$ e $R_{2}$. 


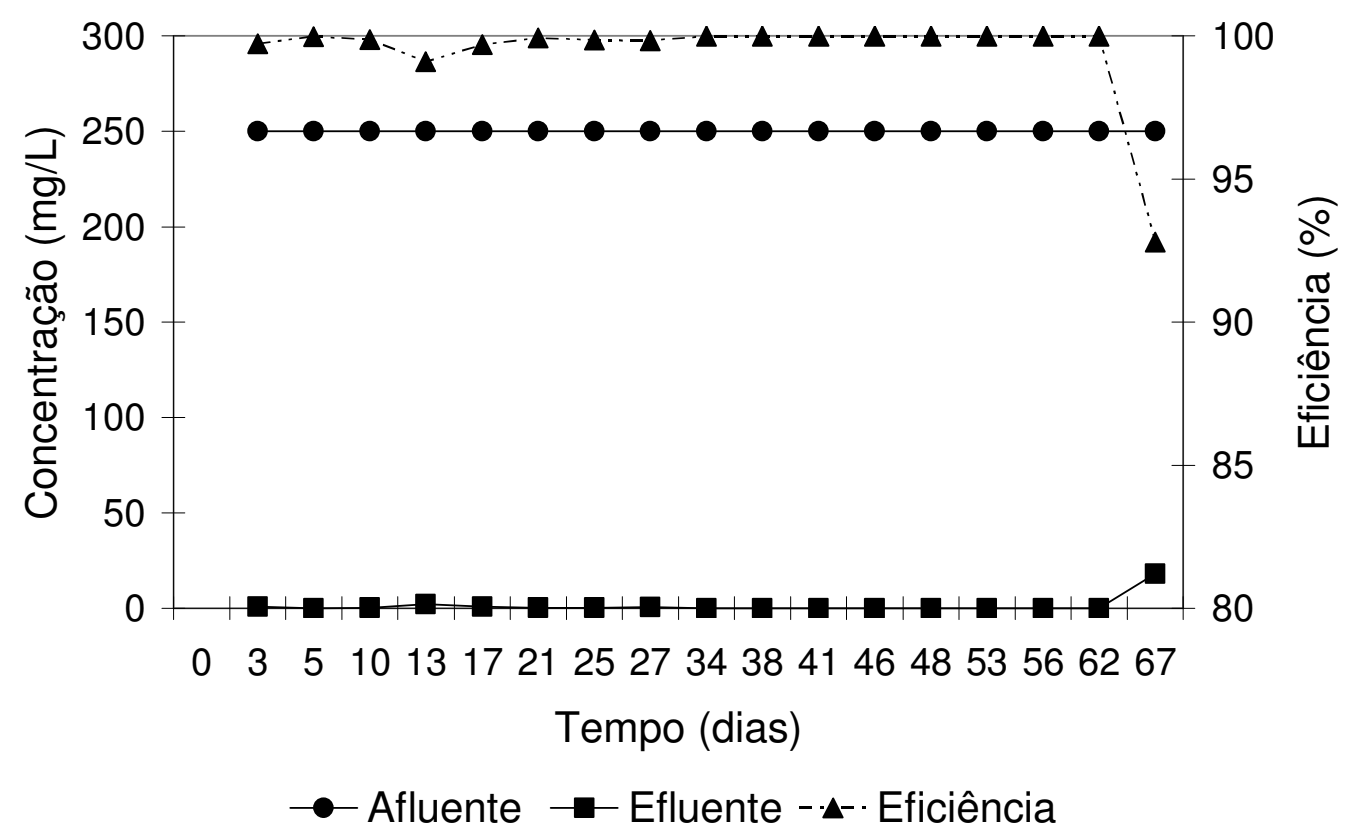

Figura 5.13: Variações das concentrações de fenol no afluente e efluente do reator com meio suporte de manta de polipropileno $\left(\mathrm{R}_{1}\right)$, no TDH de $8 \mathrm{~h}$ e Fase I (alimentação com glicose).

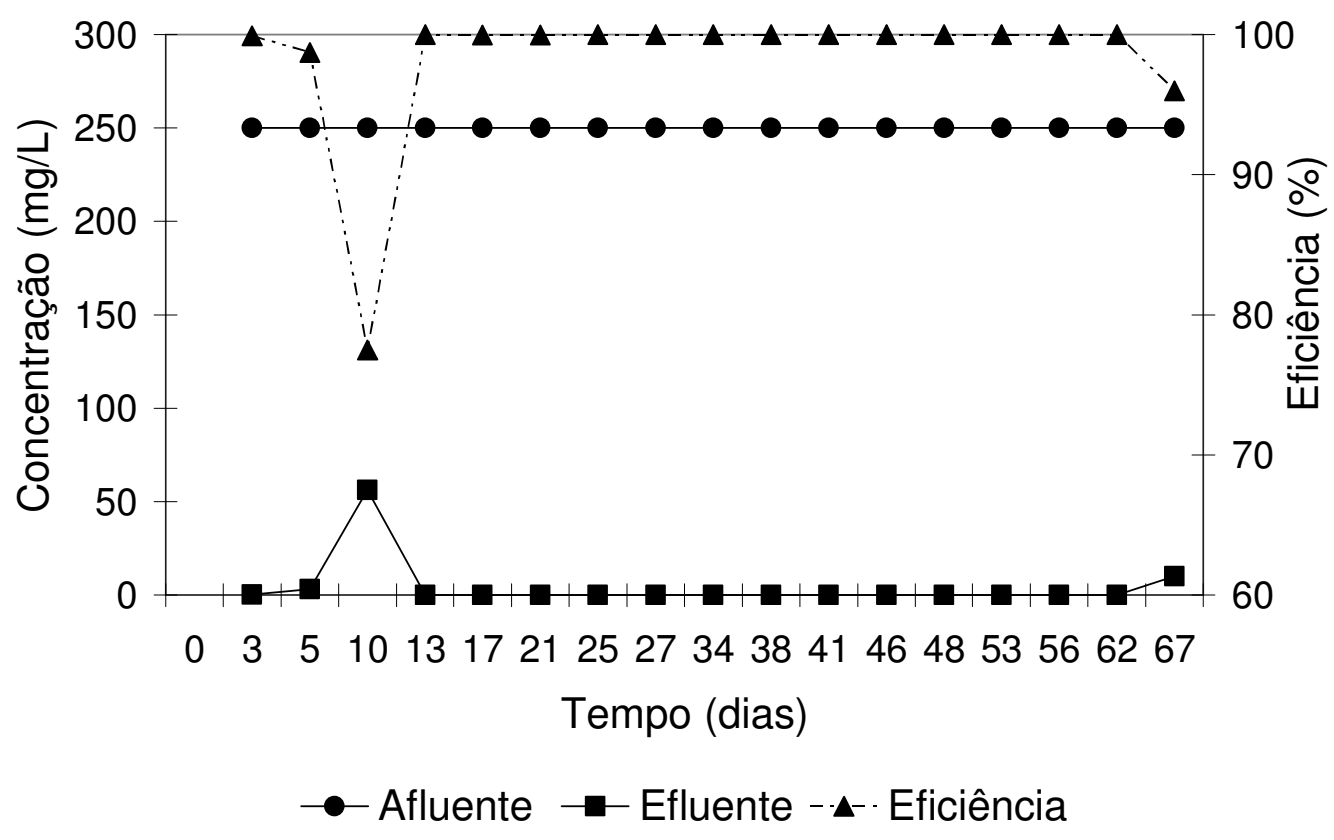

Figura 5.14: Variações das concentrações de fenol no afluente e efluente do reator com meio suporte de espuma de poliuretano $\left(\mathrm{R}_{2}\right)$, no TDH de $8 \mathrm{~h}$ e Fase I (alimentação com glicose). 
A maior concentração de fenol no efluente de $\mathrm{R}_{2}$ ocorreu no $10^{-}$dia de operação, de $56 \mathrm{mg} / \mathrm{L}$, representando $78 \%$ de eficiência de remoção de fenol em relação aos demais dias, sendo motivada pela paralisação da aeração no dia anterior à coleta.

De acordo com García-Peña et al. (2001), os fungos podem produzir quantidade substancial de filamentos que obstruem as entradas de ar, além do próprio meio suporte onde se encontram aderidos, apontando o controle da fonte de carbono como mecanismo de controle do crescimento, tento no que se refere à concentração quanto ao tipo da fonte de carbono disponível.

Neste trabalho, ao longo da presente fase de operação, o maior inconveniente observado em relação ao crescimento dos fungos foi a freqüentemente obstrução da tubulação de entrada de ar com biomassa, embora, no final desta fase, nos efluentes de ambos os reatores, tenham sido obtidas concentrações consideráveis de fenol, de $18 \mathrm{mg} / \mathrm{L}$ e $10 \mathrm{mg} / \mathrm{L}$, respectivamente, em $\mathrm{R}_{1}$ e $\mathrm{R}_{2}$, estando, possivelmente, relacionadas ao aumento da espessura do biofilme, o que também é endossado por Kapdan e Kargi (2002). Segundo esses autores, existe relação entre as limitações da difusão de substrato e o aumento da espessura do biofilme em reatores. O aumento da espessura do biofilme causa a limitação do transporte de fontes de carbono e de enzimas, resultando na perda de eficiência do processo.

As elevações das concentrações de fenol, observadas nesta pesquisa, coincidiram com a diminuição do consumo de glicose, em ambos os reatores. No $67^{\circ}$ dia, o consumo de glicose no reator $R_{1}$ foi de $78 \%$, enquanto que o consumo médio de glicose foi de $97 \% \pm 5$, e, no reator $\mathrm{R}_{2}$, de $90 \%$, sendo o consumo médio de $93 \% \pm 23$. Assim, a diminuição da eficiência de remoção de fenol e do consumo de glicose foi causada pelo aumento da espessura do biofilme.

Porém, de modo geral, a glicose, adicionada à água residuária como co-substrato, foi prontamente assimilada pelos microrganismos na maioria do período de operação dos reatores, sendo consumida do meio paralelamente à utilização do fenol como fonte de carbono. Os consumos médios de glicose pelos microrganismos foram de $97 \% \pm 5$ $\left(\mathrm{R}_{1}\right)$ e $94 \% \pm 1\left(\mathrm{R}_{2}\right)$, respectivamente, em $\mathrm{R}_{1}$ e $\mathrm{R}_{2}$ e não ocorreu inibição do uso de fenol como fonte de carbono, uma vez que a eficiência de remoção deste poluente foi elevada tanto no reator $R_{1}$ quanto no $R_{2}$. 
Verificou-se, ainda, que, ao longo desta fase de operação, mesmo quando a concentração média de glicose nos afluentes dos reatores foi de $200 \mathrm{mg} / \mathrm{L}$, entre os dias 27 e 38, não foi obtida perda de eficiência de remoção de fenol, com as remoções médias de fenol, nestes dias, de $98 \% \pm 3\left(\mathrm{R}_{1}\right)$ e $99 \% \pm 1\left(\mathrm{R}_{2}\right)$.

Com relação aos ácidos graxos voláteis (AGV), foram detectadas, no efluente do reator $R_{1}$, concentrações variando de $0,12 \mathrm{mg} / \mathrm{L}$ a $1,30 \mathrm{mg} / \mathrm{L}$ e, no reator $R_{2}$, de $0,14 \mathrm{mg} / \mathrm{L}$ a $4,32 \mathrm{mg} / \mathrm{L}$, dos ácidos acético, propiônico, isobutírico, butírico, isovalério, valérico e capróico. As variações das concentrações de AGV nos efluentes dos reatores $R_{1}$ e $R_{2}$ são mostradas, respectivamente, nas Figuras 5.15 e 5.16.

De acordo com Damasceno et al. (2003), os ácidos orgânicos voláteis, produtos do metabolismo microbiano durante a utilização da água residuária, são produzidos pelos fungos em função do substrato utilizado. Esses autores observaram a presença de acetato, butirato e propionato em efluente da indústria de beneficiamento da mandioca tratado por Geotrichum fragrans, em concentrações mais altas que as encontradas nesta pesquisa, de 5,2 a 89,5 mg/L. Contudo, as concentrações baixas de AGV, obtidas nos efluentes dos reatores $\mathrm{R}_{1}$ e $\mathrm{R}_{2}$, são resultado do consumo efetivo do substrato, estando mais relacionada à utilização da glicose, uma vez que esses ácidos não fazem parte da rota de degradação aeróbia do fenol. De qualquer forma, os ácidos presentes no meio foram produzidos e depois consumidos pelos próprios microrganismos atuantes no processo de degradação.

Nas Figuras 5.17 e 5.18 são mostradas as variações de pH no afluente e efluente dos reatores $R_{1}$ e $R_{2}$, respectivamente. Observou-se que, no reator $R_{2}$, a concentração de ácidos orgânicos voláteis no efluente foi maior no início da operação e diminuiu ao longo do tempo, em contraposição à variação do pH (Figura 5.18). O efluente foi ácido (pH de 3,0 a 6,0) até o $13^{\circ}$ dia, após o qual apresentou $\mathrm{pH}$ com valores característico de meio neutro a ligeiramente alcalino, entre 7,2 e 7,9.

Além disso, entre os dias 48 e 62, quando ocorreu ligeiro aumento, da concentração de $\mathrm{AGV}$ no efluente, houve pequeno decréscimo do valor do $\mathrm{pH}$, em torno de 0,6 unidades, indicando que maior concentração destes ácidos influenciaria na manutenção de valores menores de $\mathrm{pH}$, mais propícios para o desenvolvimento dos fungos e com maior inibição do crescimento bacteriano. 


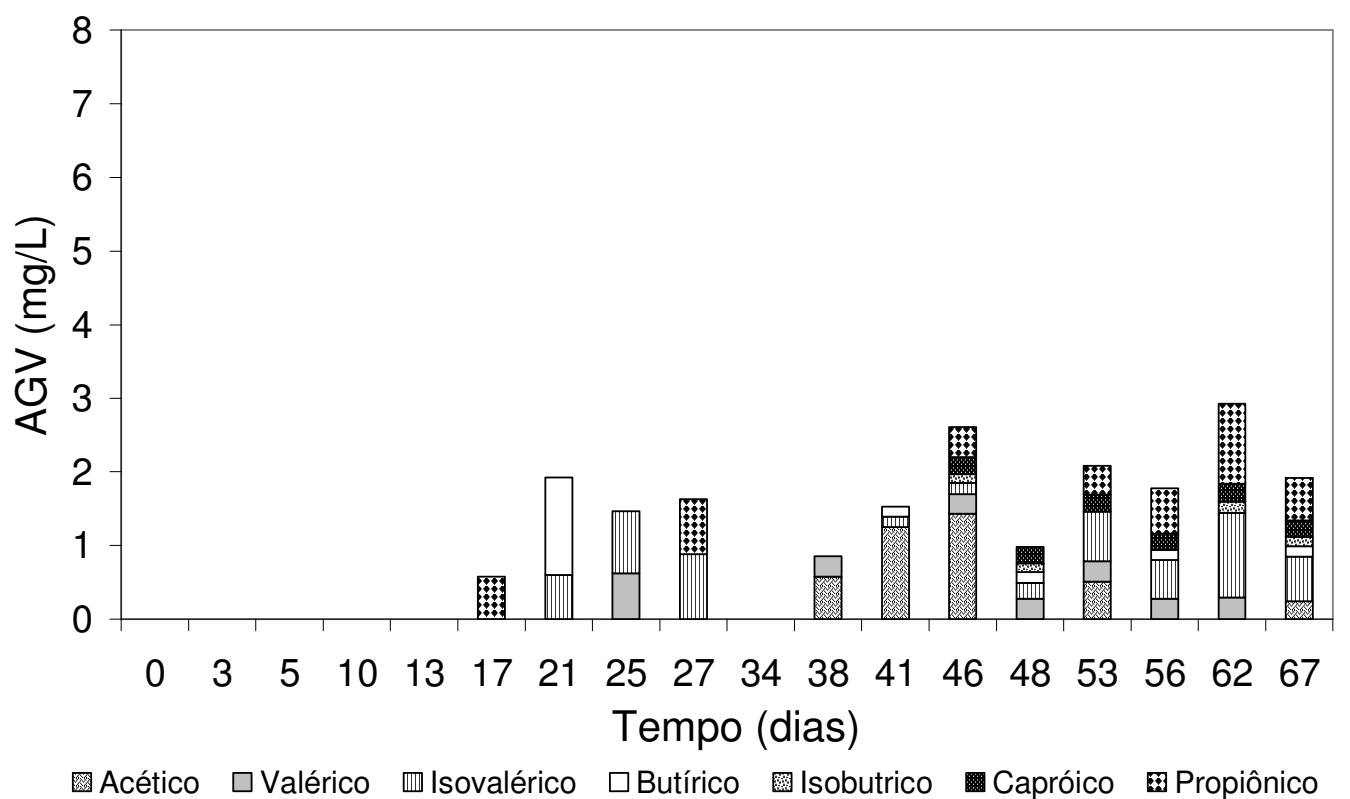

Figura 5.15: Variações das concentrações de AGV no efluente do reator com meio suporte de manta de polipropileno $\left(\mathrm{R}_{1}\right)$, no TDH de $8 \mathrm{~h}$, Fase I (alimentação com glicose).

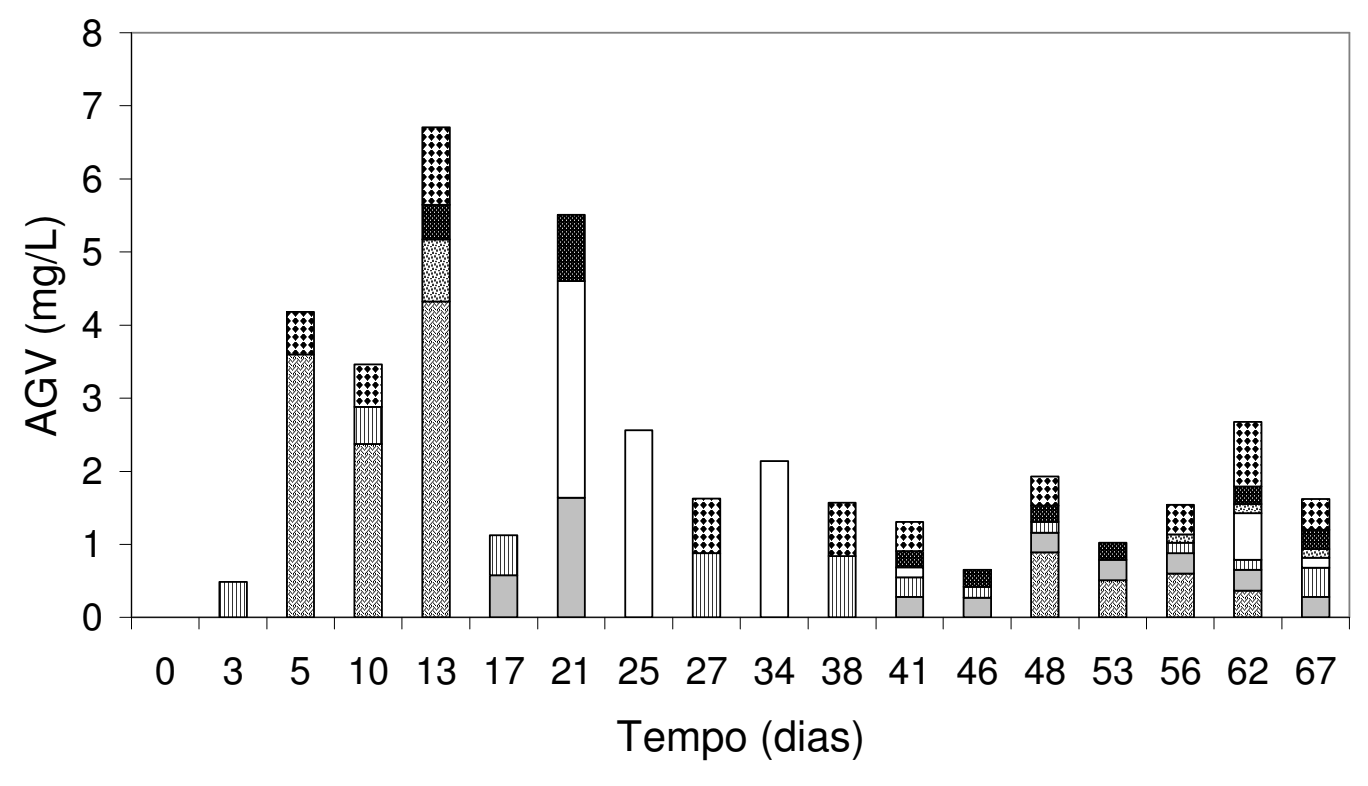

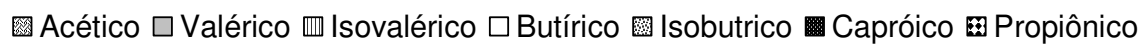

Figura 3.16: Variações das concentrações de AGV no efluente do reator com meio suporte de espuma de poliuretano $\left(\mathrm{R}_{2}\right)$, no TDH de $8 \mathrm{~h}$, Fase I (alimentação com glicose). 


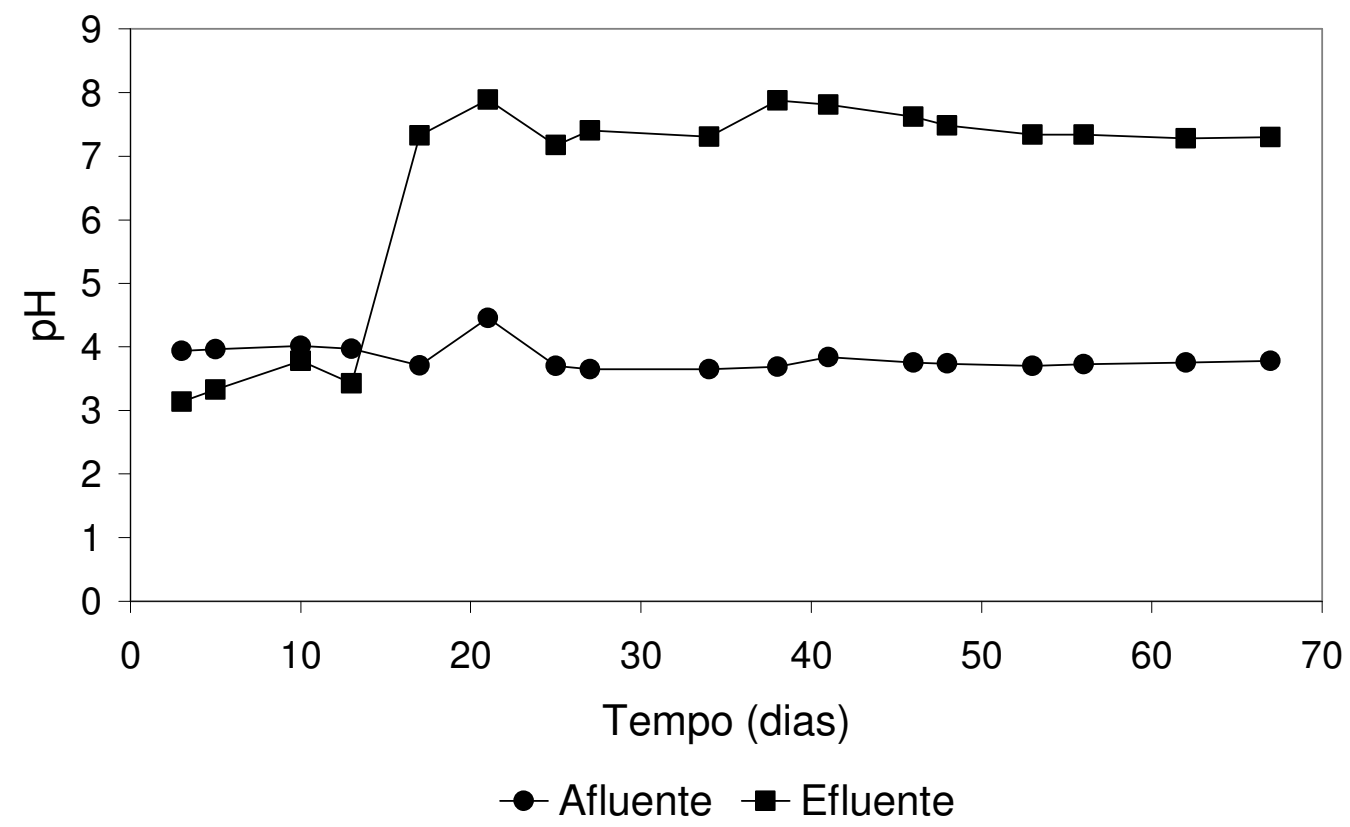

Figura 5.17: Variações do pH no afluente e efluente do reator com meio suporte de manta de polipropileno $\left(\mathrm{R}_{1}\right)$, no TDH $8 \mathrm{~h}$, Fase I (alimentação com glicose).

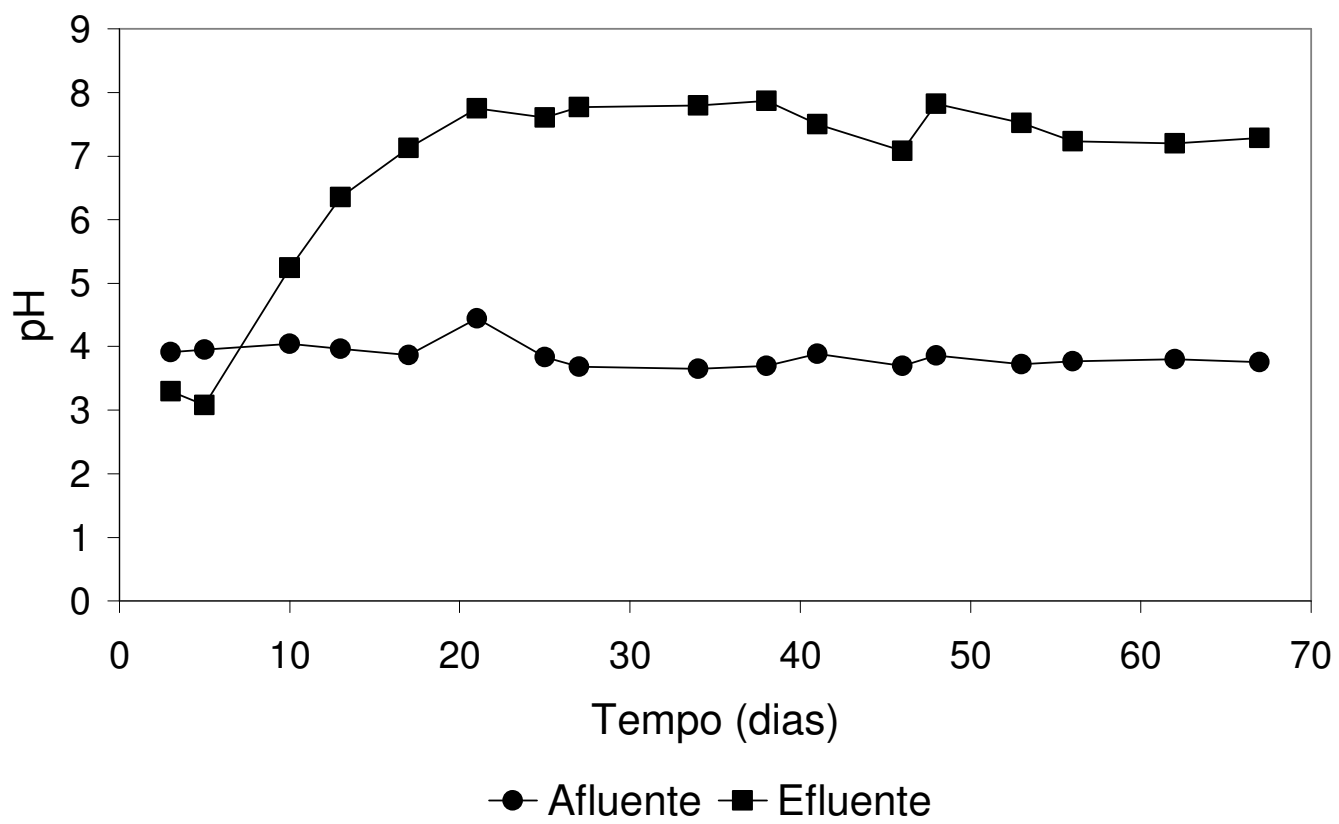

Figura 5.18: Variações do $\mathrm{pH}$ no afluente e efluente do reator com meio suporte de espuma de poliuretano $\left(\mathrm{R}_{2}\right)$, no TDH $8 \mathrm{~h}$, Fase I (alimentação com glicose). 
Da mesma forma, quando o efluente do reator $\mathrm{R}_{1}$ apresentou maior presença de AGV, entre os dias 53 e 67, observou-se ligeira diminuição do valor do pH em 0,6 unidade.

Embora a faixa ideal de $\mathrm{pH}$ para o crescimento dos fungos, de modo geral, seja de 4,0 a 7,0, eles são capazes de sobreviver e crescer em meio com uma faixa mais ampla de pH, de 2,0 a 9,0 (GRIFFIN, 1994; CARLILE e WATKINSON, 1994).

É importante mencionar que os fungos, freqüentemente, alteram o $\mathrm{pH}$ do meio no qual se encontram devido às reações diferenciadas de ânions e cátions (GRIFFIN, 1994).

De acordo com Papagianni (2004), durante o crescimento dos fungos, meios que possuem nitrato em sua composição, tendem a se tornar alcalinos, devido à conversão do nitrato em amônia.

No processo de conversão do nitrato em amônia, o nitrato é primeiramente convertido a nitrito, sob a ação da enzima nitrato redutase, que, então, será convertido à amônia, forma na qual o nitrogênio é assimilado pelos fungos, mediante a atuação da enzima nitrito redutase, ocorrendo consumo de prótons do meio (ZEHNDER, 1988; GRIFFIN, 1994), conforme mostrado nas Equações 5.1 e 5.2.

$$
\begin{array}{ll}
\mathrm{NADH}+\mathrm{H}^{+}+\mathrm{NO}_{3}^{-} \longrightarrow \mathrm{NO}_{2}^{-}+\mathrm{NAD}^{+}+\mathrm{H}_{2} \mathrm{O} & \text { Equação (5.1) } \\
6 \mathrm{e}^{-}+\mathrm{NO}_{2}^{-}+8 \mathrm{H}^{+} \longrightarrow \mathrm{NH}_{4}^{+}+2 \mathrm{H}_{2} \mathrm{O} & \text { Equação (5.2) }
\end{array}
$$

A elevação do $\mathrm{pH}$ do meio tem sido observada em trabalhos com reatores com fungos, como os de Rodrigues (1999), Santaella et al. (1999) e Sampaio et al. (2004), registrando-se, paralelamente, o consumo de nitrato do meio.

Rodrigues (1999) registrou a elevação do $\mathrm{pH}$ do meio, de 7,0 para 8,5, acompanhado do consumo de nitrato, ao utilizar reator de leito fixo e escoamento ascendente, operado no tempo de detenção hidráulica de 31 h, com as espécies Drechslera monocerans e Aspergillus fumigatus, para o tratamento de água residuária sintética de laticínios. 
Santaella (1999) observou o consumo de nitrato ao operarem reator com fungos no tempo de detenção hidráulica de 12 h para o tratamento de água residuária da indústria da castanha de caju. Paralelamente à remoção de nitrato, houve elevação do $\mathrm{pH}$ do efluente.

Sampaio et al. (2004), ao tratar a mesma água residuária empregada por Santaella (1999) em reator com fungos como pós-tratamento de reator UASB, verificou que, no reator com fungos, o $\mathrm{pH}$ do efluente foi superior ao do afluente em todos os tempos de detenção estudados ( 4 h, 2 h e 1 h), também atribuiu a elevação do pH ao mecanismo de assimilação de nitrato, bem como à remoção de $\mathrm{CO}_{2}$ do meio, devido ao processo de aeração.

Assim sendo, a conversão de nitrato à amônia é outro fator que influencia a elevação do pH da água residuária, pois, segundo Ainbsworth e Sussman (1966), a amônia geralmente é consumida em pH elevado, em torno de 8 , no qual se descartando sua volatilização do meio, que ocorre somente em pH de 10,5 a 11,5 (METCALF e EDDY, 1991), estando disponível para ser assimilada pelos fungos como fonte de nitrogênio.

No caso da assimilação de hidrocarbonetos aromáticos, como o fenol, outro fator que teria contribuído para a elevação do pH é própria via de assimilação do composto, pois produtos hidroxilados podem também aparecer como resultado da conjugação com metil, glucosideos, glucoronideos e intermediários da xilose, os quais são excretados no meio pelos fungos (PRENAFETA BOLDÚ, 2002). De fato, isto condiz com os valores de DQO solúvel, encontrados neste trabalho, os quais indicaram remoção maior de fenol em relação à de matéria orgânica.

As variações de oxigênio dissolvido são mostradas nas Figuras 5.19 e 5.20.

A concentração média de oxigênio dissolvido nos reatores $R_{1}$ e $R_{2}$ foram de $5 \mathrm{mg} / \mathrm{L} \pm 1$ e de $6 \mathrm{mg} / \mathrm{L} \pm 1$, respectivamente. Comparando os resultados de oxigênio dissolvido com a remoção de matéria orgânica, medida em DQO, no efluente do reator $\mathrm{R}_{1}$, observou-se que quando foram registradas as menores concentrações de oxigênio

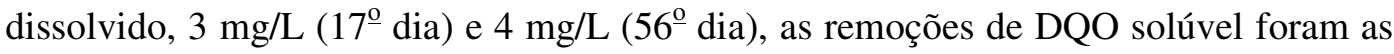
menores alcançadas pelo reator nesta fase de operação, de $89 \%$ e $85 \%$, respectivamente. 


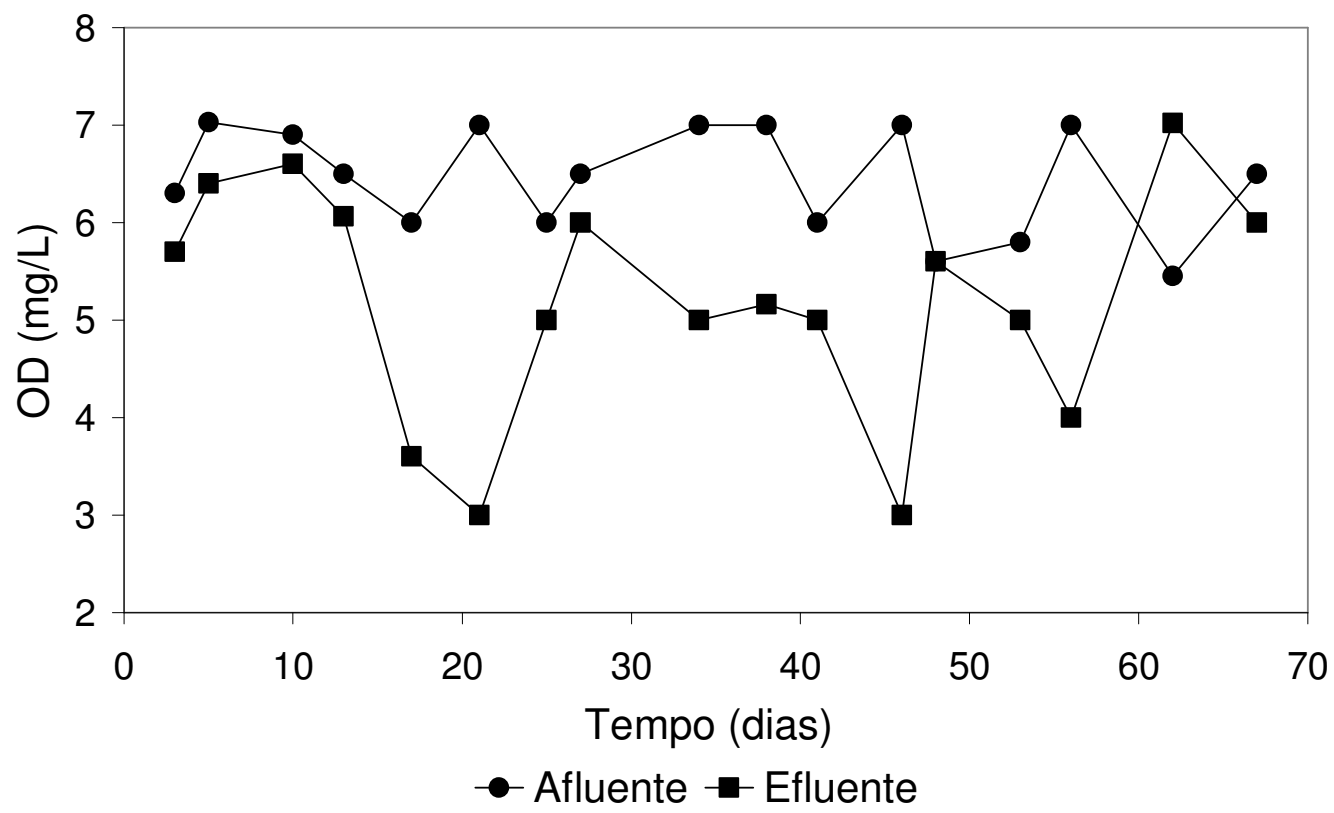

Figura 5.19: Variações das concentrações de OD no afluente e efluente do reator com meio suporte de manta de polipropileno $\left(\mathrm{R}_{1}\right)$, TDH $8 \mathrm{~h}$, Fase I (alimentação com glicose).

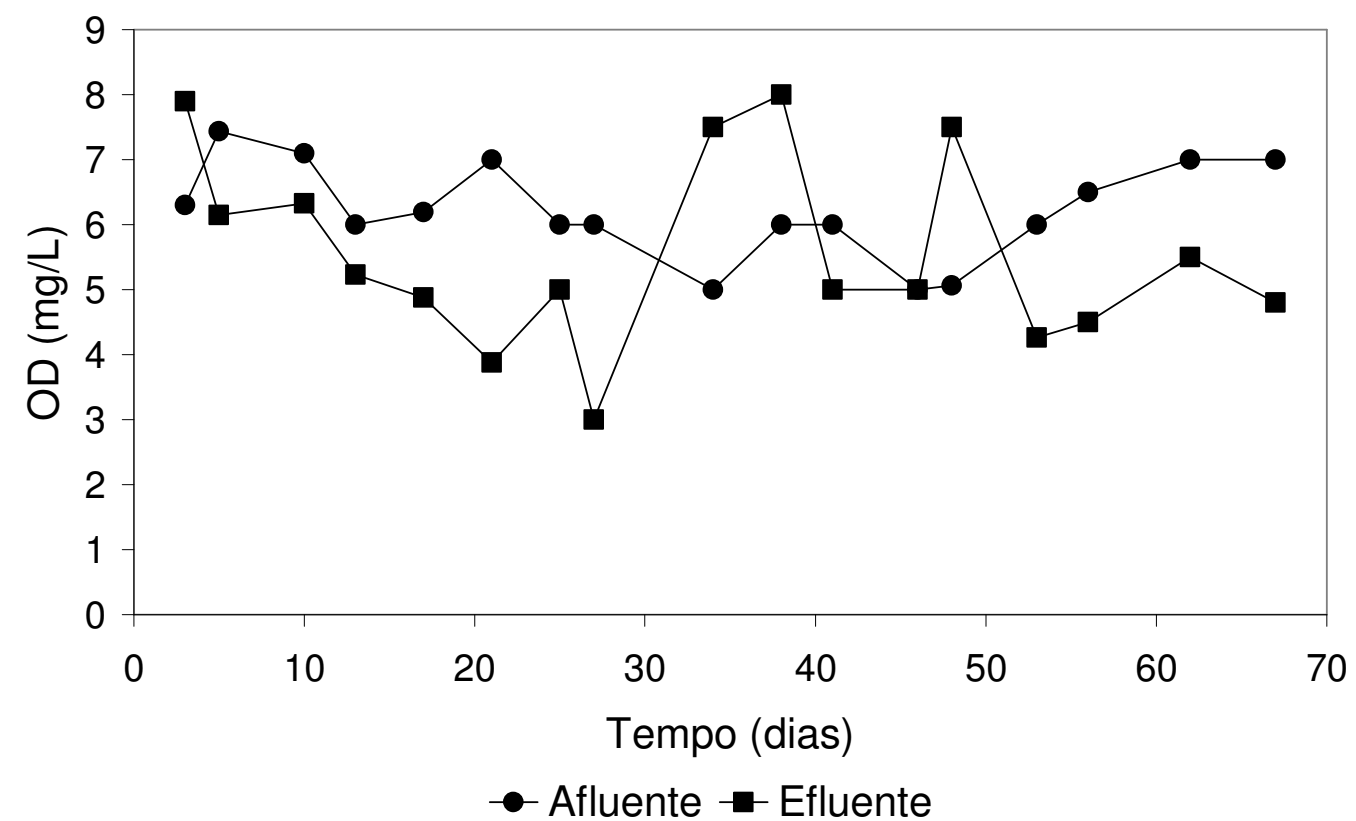

Figura 5.20: Variações das concentrações de oxigênio dissolvido no afluente e efluente do reator com meio suporte de espuma de poliuretano $\left(\mathrm{R}_{2}\right)$, TDH $8 \mathrm{~h}$, Fase I (alimentação com glicose). 
Em relação à remoção de fenol, a diminuição da concentração no meio não foi prejudicada pelos valores mais baixos de oxigênio dissolvido, reforçando a hipótese de que substâncias ligadas ao anabolismo a partir do uso de fenóis sejam responsáveis pelos valores mais altos de DQO solúvel.

No reator $\mathrm{R}_{2}$, a menor redução da concentração de DQO solúvel foi obtida na presença de concentração de oxigênio dissolvido superior à encontrada no reator $\mathrm{R}_{1}$, de $6 \mathrm{mg} / \mathrm{L}$, embora este percentual de remoção de matéria orgânica tenha sido obtido ainda no início da operação do reator, no começo da adaptação dos microrganismos à água residuária.

A oscilação dos valores de oxigênio dissolvido nos efluentes dos reatores, ao longo desta fase, ocorreu pela dificuldade de se manter a aeração adequada, devido ao crescimento de biomassa que, freqüentemente, obstruía a entrada de ar.

O crescimento acentuado de fungos também foi observado por Guimarães et al. (2005) ao utilizarem reator biológico de contato (volume total de $6 \mathrm{~L}$ ), com meio suporte de espuma de poliuretano, inoculado com Phanerochaete chrysosporium, para remoção de cor de água residuária de uma refinaria de açúcar. Até o $17^{0}$ dia de operação, foi obtida uma remoção média de $54 \%$ da cor e de $62 \%$ de fenóis totais, contudo, após esse dia, houve a diminuição progressiva da remoção de cor e foi observando crescimento excessivo do biofilme.

Contudo, é importante ressaltar que, nesta pesquisa, os valores mais baixos de oxigênio dissolvido não resultaram em perda considerável da eficiência de remoção de matéria orgânica e de fenol, demonstrando a capacidade dos fungos de se adaptarem às concentrações mais baixas de oxigênio dissolvido ( $3 \mathrm{mg} / \mathrm{L})$.

Considerando a temperatura como fator importante nos processos biológicos de tratamento de águas residuárias, os reatores $R_{1}$ e $R_{2}$ foram operados em faixa de temperatura entre $16,7^{\circ} \mathrm{C}$ a $25,0^{\circ} \mathrm{C}$. Aparentemente, não houve influência da variação da temperatura sobre o desempenho do sistema, pois mesmo nos dias que apresentaram temperaturas mais baixas, as eficiências de remoção do fenol foram altas. 


\subsubsection{Operação dos reatores TDH de $8 \mathrm{~h}$ - alimentação sem glicose (Fase II)}

Os reatores $\mathrm{R}_{1}$ e $\mathrm{R}_{2}$ foram mantidos sob regime de escoamento contínuo, passando os reatores a receber apenas fenol $(250 \mathrm{mg} / \mathrm{L})$ como única fonte de carbono.

$O$ reator $R_{1}$ alcançou eficiência de remoção média de matéria orgânica de $95 \% \pm$ 2, em termos de DQO solúvel, diferença muito pequena em relação à obtida na fase de operação anterior $(93 \% \pm 4)$, com glicose.

No reator $\mathrm{R}_{2}$, houve perda de eficiência de remoção de DQO solúvel, em relação à fase anterior. A remoção média de matéria orgânica no efluente filtrado, medida em DQO, foi de $89 \% \pm 12$. A perda de eficiência foi atribuída à obstrução do meio suporte pelo crescimento dos microrganismos e pela grande produção de material gelatinoso esbranquiçado, possivelmente um polímero extracelular, limitando a passagem do substrato.

Nas Figuras 5.21 e 5.22 são mostradas as variações da DQO e, nas Figuras 5.23 e 5.24, as da eficiência de remoção de matéria orgânica, respectivamente, para os reatores $\mathrm{R}_{1}$ e $\mathrm{R}_{2}$ no TDH $8 \mathrm{~h}$ - Fase II. No efluente bruto, a remoção média de matéria orgânica foi de $90 \% \pm 5$ e $83 \% \pm 15$, respectivamente, para os reatores $R_{1}$ e $R_{2}$.

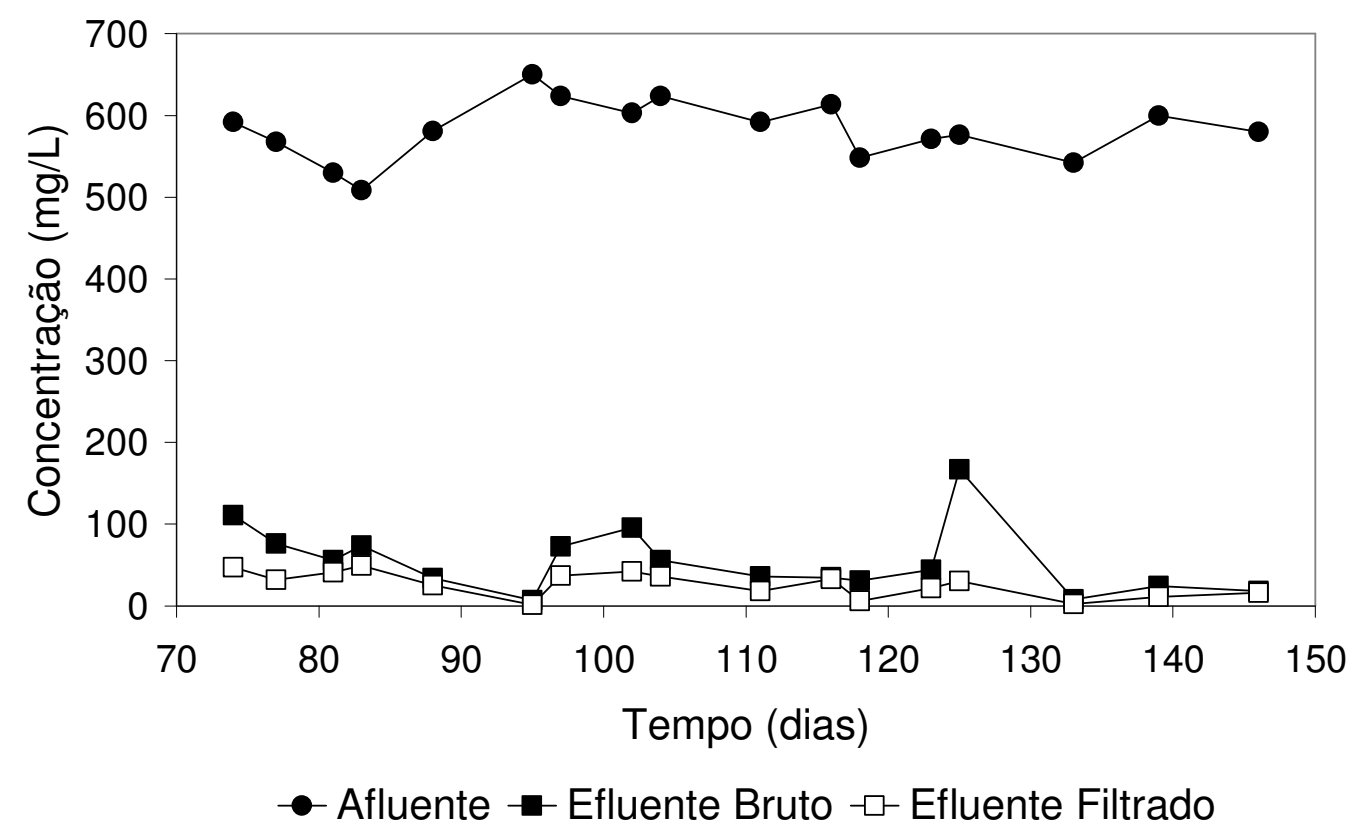

Figura 5.21: Variações das concentrações de matéria orgânica, medida em DQO, no afluente e efluente do reator com manta de polipropileno $\left(\mathrm{R}_{1}\right)$, no TDH $8 \mathrm{~h}$, Fase II (alimentação sem glicose). 


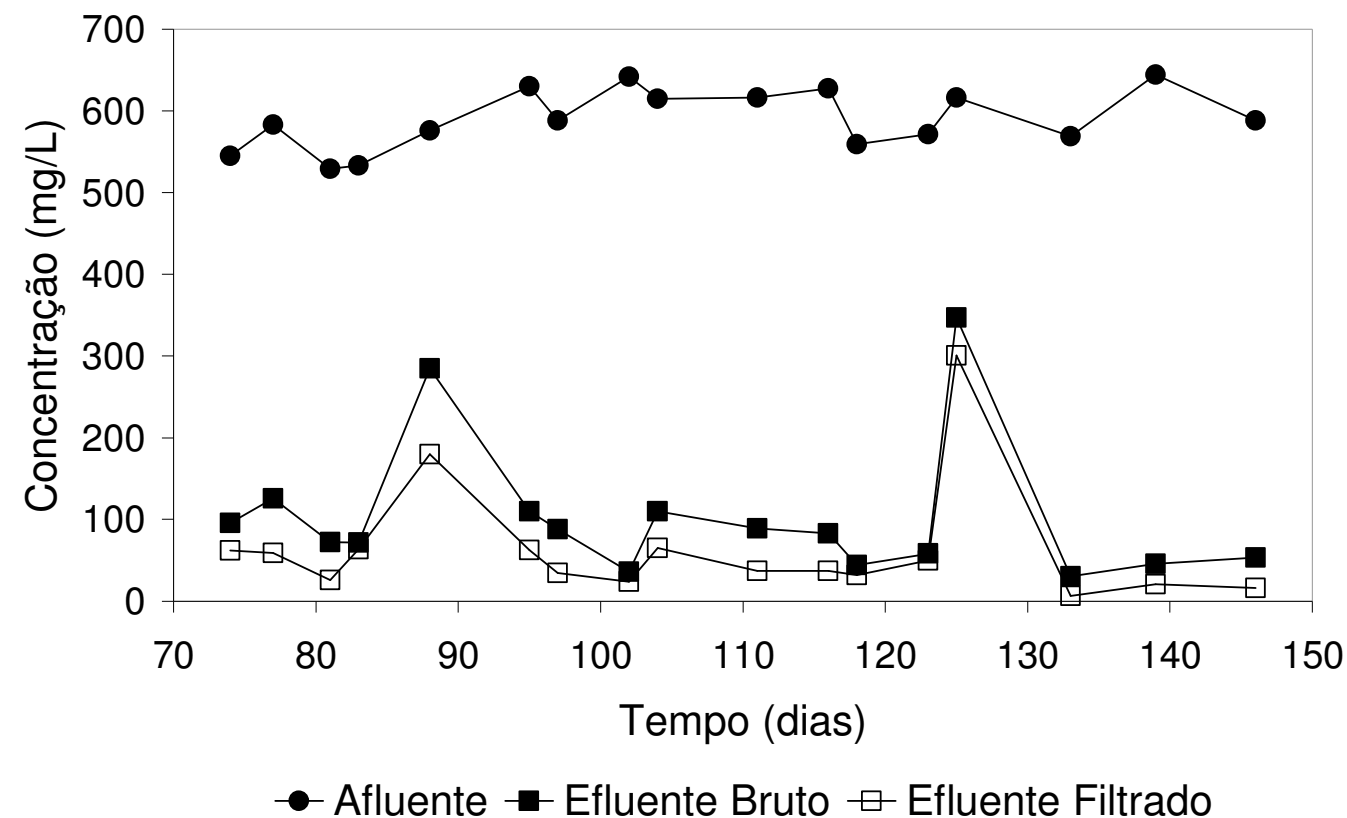

Figura 5.22: Variações das concentrações de matéria orgânica, medida em DQO, no afluente e efluente do reator com espuma de poliuretano $\left(\mathrm{R}_{2}\right)$, no TDH 8 h, Fase II (alimentação sem glicose).

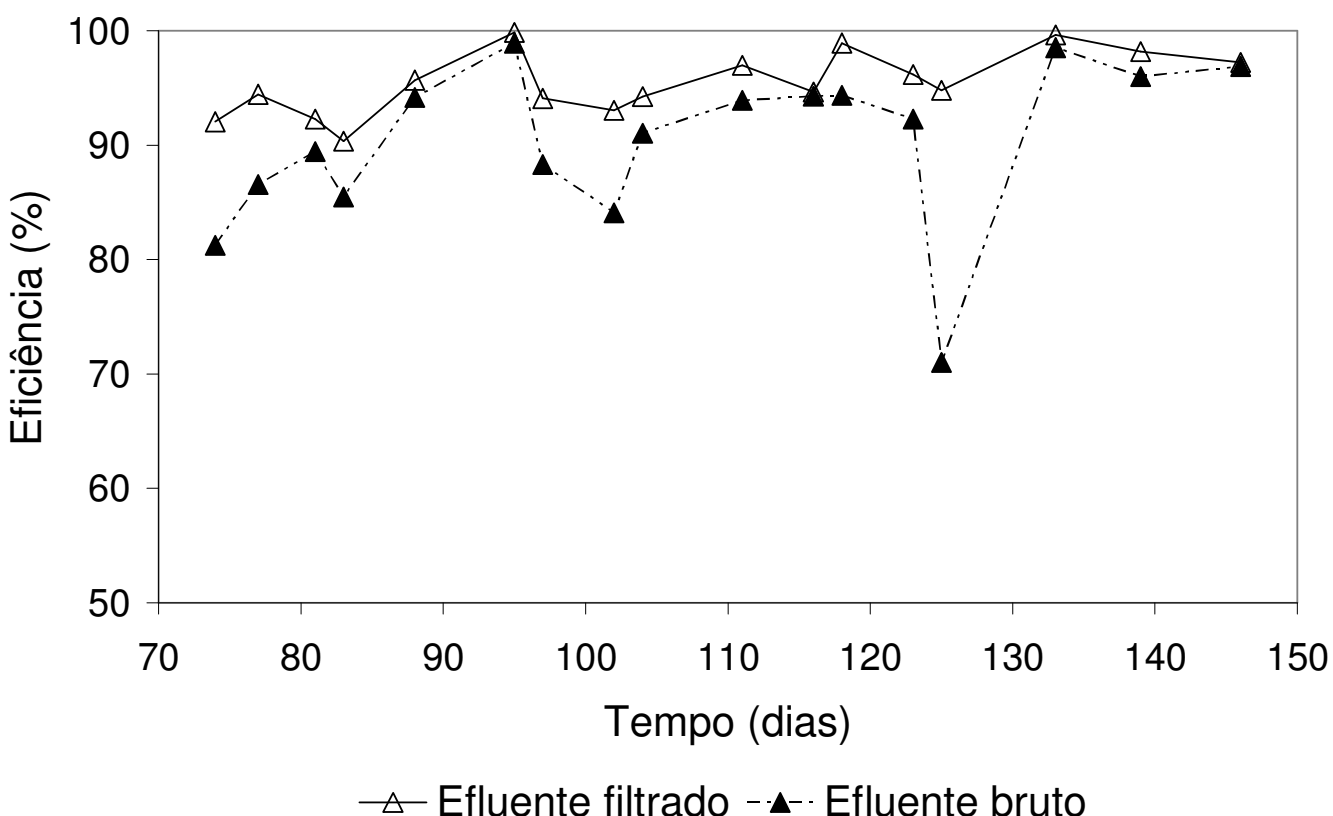

Figura 5.23: Variações das eficiências de remoção de matéria orgânica, medida em DQO, no afluente e efluente do reator com manta de polipropileno $\left(\mathrm{R}_{1}\right)$, no TDH $8 \mathrm{~h}$, Fase II (alimentação sem glicose). 


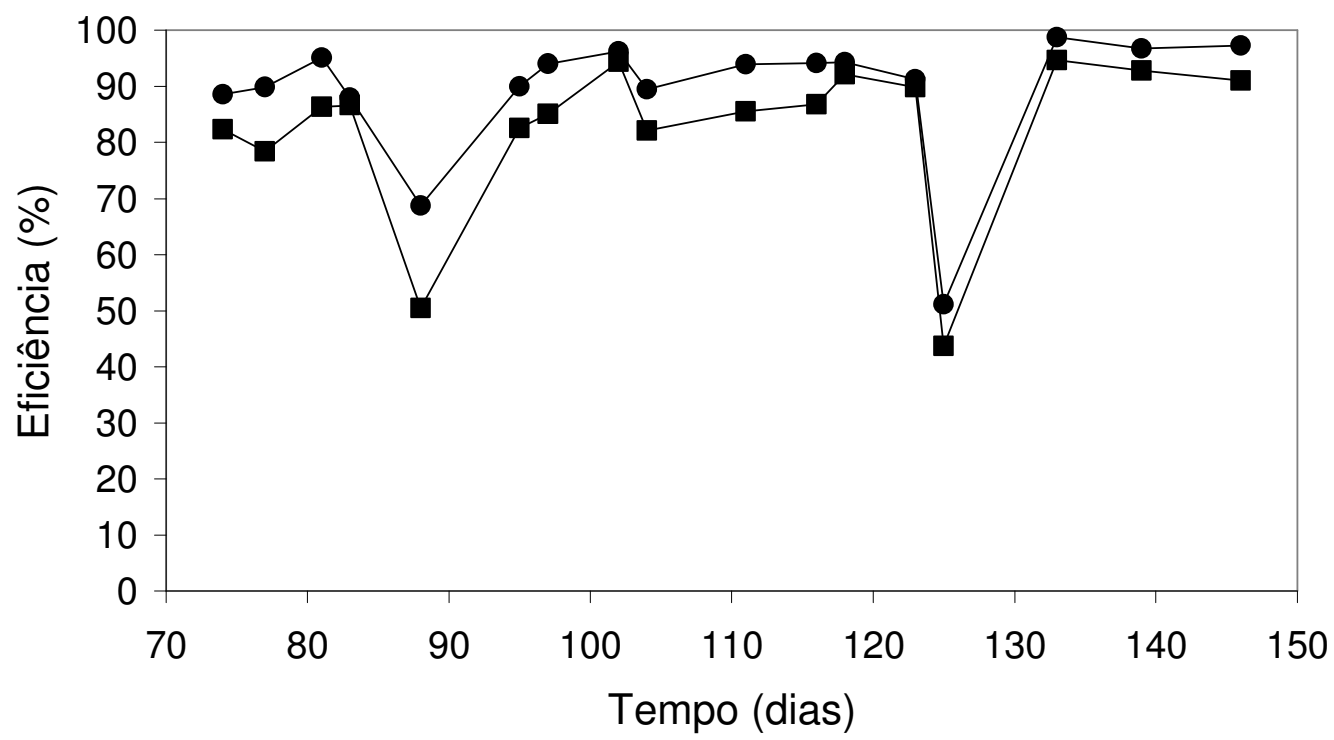

- Efluente filtrado - Efluente bruto

Figura 5.24: Variações das eficiências de remoção de matéria orgânica, medida em DQO, no afluente e efluente do reator com espuma de poliuretano $\left(\mathrm{R}_{2}\right)$, no TDH $8 \mathrm{~h}$, Fase II (alimentação sem glicose).

Nesta fase de operação, verificou-se, na altura média do reator $R_{2}$, a $40 \mathrm{~cm}$ da base, o surgimento de zona morta e de caminhos preferenciais, possivelmente, devido à compactação do meio suporte. A espuma de poliuretano, ao longo do tempo de operação do reator, foi gradualmente empurrada e resultou na formação de um espaço vazio.

Acima desse espaço, observou-se grande compressão do meio suporte e do biofilme contra o contentor, além de quantidade substancial de material esbranquiçado gelatinoso, que dificultava a passagem de água para a camada superior do meio suporte. A perda de carga resultante fez com que a água residuária adentrasse a tubulação de ar, ocasionando as freqüentes paralisações do sistema de aeração.

Optou-se, então, pela paralisação do sistema, após a $5^{\underline{a}}$ coleta dessa fase $\left(88^{\underline{0}}\right.$ dia de operação), e uma haste de aço inoxidável foi introduzida pela parte superior do reator, procurando-se desprender os cubos de espuma uns dos outros. Este procedimento eliminou o espaço vazio dentro do reator que passou a ser operado sob condições normais até a $14^{\mathrm{a}}$ coleta $\left(120^{\mathrm{o}}\right.$ dia de operação), quando novamente foi observada a 
presença de novas zonas mortas (Figura 5.25), contribuindo para a perda de eficiência da remoção de matéria orgânica (DQO).

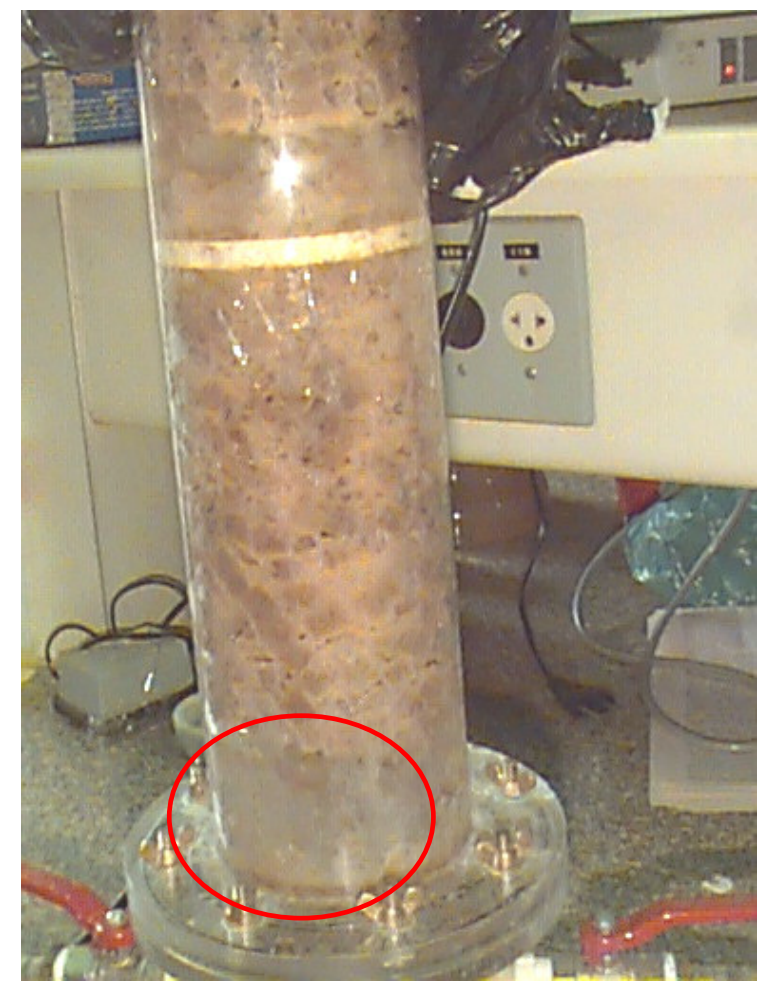

Figura 5.25: Reator com meio suporte de espuma de poliuretano $\left(\mathrm{R}_{2}\right)$ : onde pode ser observada a zona morta por compressão do meio suporte.

No reator com manta de polipropileno $\left(\mathrm{R}_{1}\right)$ também houve produção de material gelatinoso e aumento visual de biomassa, embora problemas relacionados à colmatação do meio suporte tenham sido menos freqüentes.

A formação desse material gelatinoso implicou na limpeza periódica da tubulação de saída do efluente dos reatores, pois o mesmo tendia a se depositar nas paredes internas da tubulação, obstruindo-a.

Segundo Griffin (1994), as substâncias mucilagenosas, compostas de polissacarídeos, proteínas, glicoproteínas e de enzimas como esterase, invertase e peroxidase., são produzidas pelos fungos e o ajudam a aderir no meio suporte. Entretanto, nesta pesquisa, a grande produção desses mucilágenos estaria ainda relacionada à suspensão da glicose na água residuária, pois os fungos tendem a acumular componentes intracelulares (polissacarídeos, lipídios e proteínas) e a aumentar 
a biomassa para se protegerem do efeito tóxico de compostos como o fenol (COSTA et al., 2004).

As variações das concentrações de fenol nos reatores $R_{1}$ e $R_{2}$ são apresentadas nas Figuras 5.26 e 5.27 .

No reator $R_{1}$, a eficiência média de remoção de fenol foi de $99,6 \% \pm 1$, similar à obtida na Fase I, com a adição de glicose na água residuária $(99,5 \% \pm 2)$. O menor percentual de remoção de fenol registrado foi de $97 \%$ ( $81^{\circ}$ e $88^{\circ}$ dia).

A eficiência média de remoção de fenol obtida pelo reator $R_{2}$ foi de $92 \% \pm 23$, inferior à do reator $\mathrm{R}_{1}$, nesta fase de operação. Além disso, ficou abaixo do valor alcançado pelo reator $\mathrm{R}_{2}$ quando a glicose foi adicionada na água residuária $(98 \% \pm 5)$. Porém, é importante ressaltar que o valor médio apresentado foi influenciado pelas menores remoções de fenol, ocorridas na $5^{\mathrm{a}}$ e $14^{\mathrm{a}}$ coletas, pois, ao longo da maior parte da Fase II, as remoções de fenol foram superiores à eficiência média.

A ausência da glicose, apesar de não ter interferido diretamente na perda da eficiência de remoção de fenol, propiciou o aumento da concentração de biomassa nos reatores, na forma de subprodutos gerados pelo metabolismo dos microrganismos, além do próprio material celular.

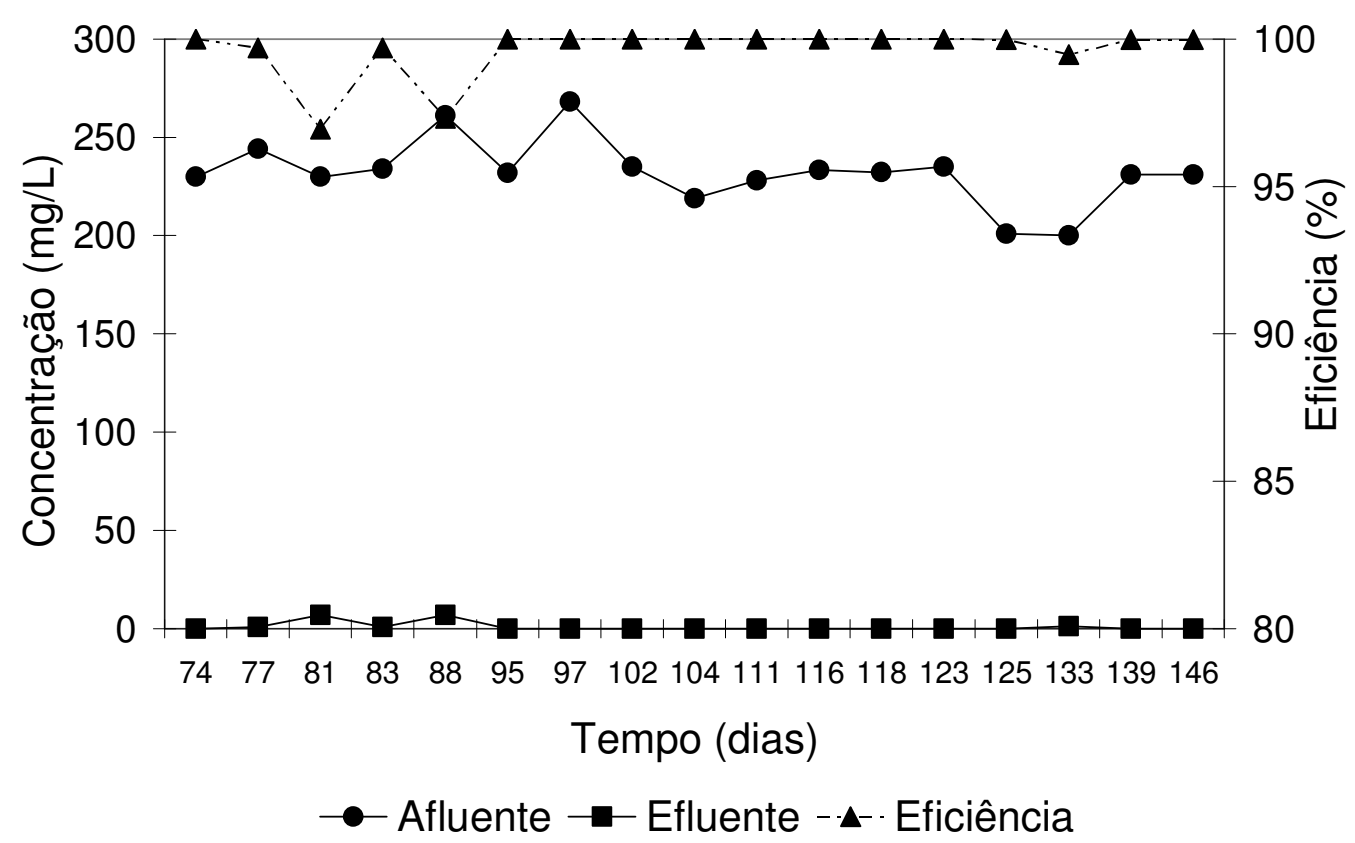

Figura 5.26: Variações das concentrações de fenol no afluente e efluente do reator com meio suporte de manta de polipropileno $\left(\mathrm{R}_{1}\right)$, no TDH 8 h, Fase II (alimentação sem glicose). 


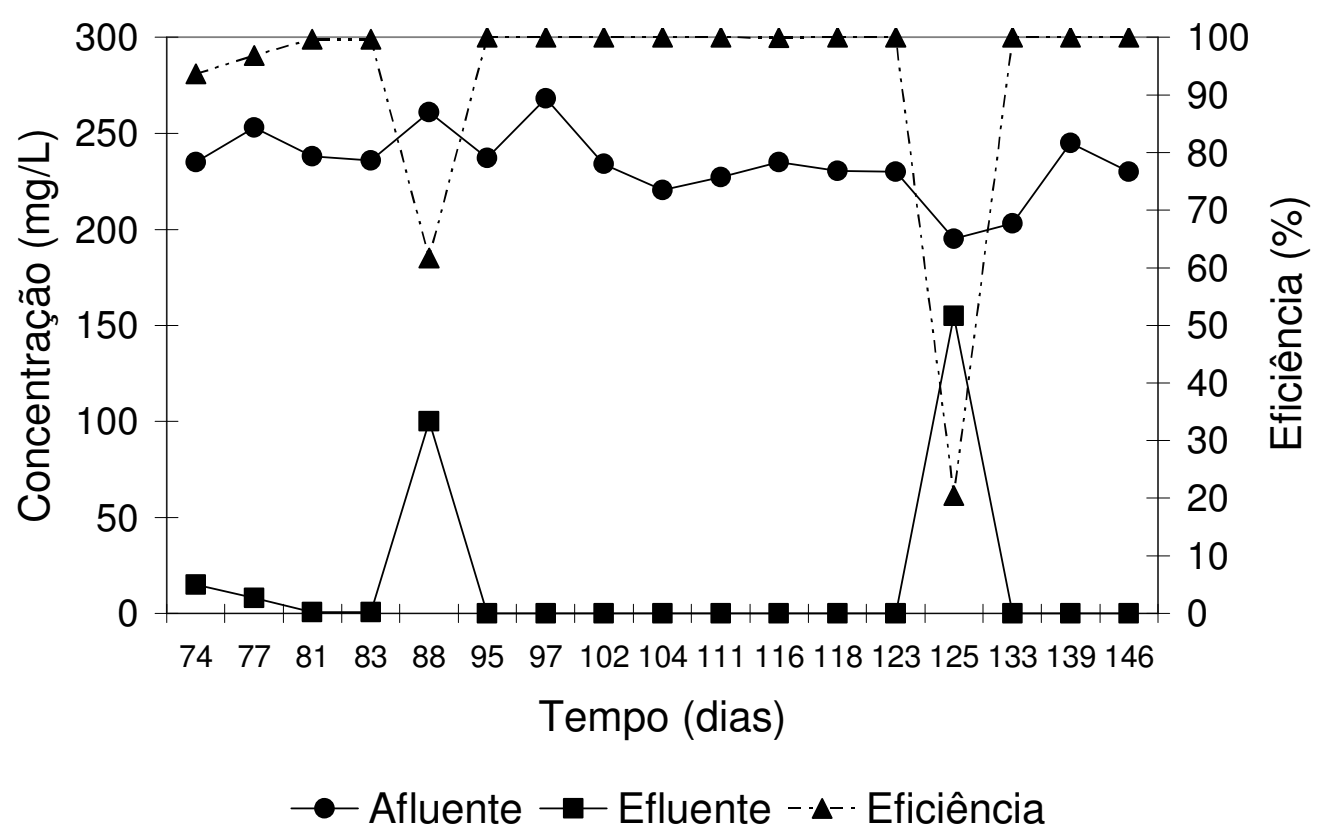

Figura 5.27: Variações das concentrações de fenol no afluente e efluente do reator com meio suporte de espuma de poliuretano $\left(\mathrm{R}_{2}\right)$, no TDH 8 h, Fase II (alimentação sem glicose).

Verificou-se, então, que a glicose não foi apenas importante no estágio inicial de formação do biofilme, conforme demonstrado no experimento em batelada, mas exerceu influencia sobre o crescimento dos fungos, não sendo apenas uma fonte mais fácil de ser assimilada, mas também promovendo o aumento da relação $\mathrm{C} / \mathrm{N}$.

Nesta pesquisa, a partir da concentração de fenol, de glicose e das fontes de nitrogênio $\left(\left(\mathrm{NH}_{4}\right)_{2} \mathrm{SO}_{4}\right.$ e $\left.\mathrm{NaNO}_{3}\right)$ na água residuária e de suas respectivas fórmulas moleculares, foram obtidas relações $\mathrm{C} / \mathrm{N}$ de 1,0 e 0,5 , respectivamente, para a água residuária com glicose (Fase I) e sem glicose (Fase II). Observou-se que, na Fase I, de maior relação $\mathrm{C} / \mathrm{N}$, caracterizada pela presença de meio onde carbono e nitrogênio estavam na mesma proporção, houve menor crescimento dos fungos em relação à Fase II, na qual a concentração de nitrogênio no meio foi o dobro da de carbono. Desta forma, o crescimento exagerado do biofilme ocorreu no meio sem limitação de nitrogênio, no qual o carbono foi o elemento limitante.

No sentido de controlar o crescimento exagerado de biomassa fúngica, é importante o estudo da composição da água residuária, pois as concentrações de carbono e nitrogênio influenciam o metabolismo fúngico (Carlile e Watikson, 1994). 
$\mathrm{Na}$ Tabela 5.3, são apresentadas relações de $\mathrm{C} / \mathrm{N}$ para substratos empregados em trabalhos com fungos em reatores biológicos, observando-se grande variação dos valores dessa relação em água residuária ou substrato sintético utilizado.

Tabela 5.3: Relações de $\mathrm{C} / \mathrm{N}$ de substratos empregados em trabalhos com fungos em reatores biológicos.

\begin{tabular}{|c|c|c|c|}
\hline Pesquisadores & Fungo & Substrato & $\mathbf{C} / \mathbf{N}$ \\
\hline $\begin{array}{c}\text { Garcia et al. } \\
(2000)\end{array}$ & $\begin{array}{l}\text { Aspergillus niger, Aspergillus } \\
\text { terreus, Geotrichum candidum, } \\
\text { Phanerochaete chrysosporium }\end{array}$ & $\begin{array}{l}\text { Água } \\
\text { residuária de } \\
\text { fábrica de } \\
\text { azeite de oliva }\end{array}$ & 13 \\
\hline $\begin{array}{c}\text { Kapdan e Kargi } \\
\text { (2002) }\end{array}$ & Coriolus versicolor & $\begin{array}{l}\text { Substrato } \\
\text { sintético }\end{array}$ & 100 \\
\hline $\begin{array}{c}\text { Sankapal e Kulkarni } \\
\text { (2002) }\end{array}$ & Aspergillus niger & $\begin{array}{l}\text { Substrato } \\
\text { sintético }\end{array}$ & 97 a 174 \\
\hline
\end{tabular}

Meios com limitação de nitrogênio e alta disponibilidade de carbono, como os utilizados por Kapdan e Kargi (2002) e Sankapal e Kulkarni (2002), favorecem o crescimento exagerado dos fungos, diferente do observado nesta pesquisa.

A água residuária sintética com corante têxtil utilizada por Kapdan e Kargi (2002), apresentou relação C/N de 100, ou seja, concentração elevada de carbono em relação à de nitrogênio. Apesar da água residuária possuir baixa concentração de nitrogênio, em contraposição à água residuárias sintética empregada nesta pesquisa, esses autores também verificaram, ao longo dos 12 dias de experimento, crescimento excessivo de biomassa dentro do reator, um biodisco com volume de 1,7 L. A elevada concentração de biomassa resultou em perda de eficiência do tratamento, devido à limitação difusional, tanto do transporte de substrato como de enzimas lignolíticas. Semelhantemente ao trabalho de Kapdan e Kargi (2002), Sankapal e Kulkarni (2002), ao utilizarem valores elevados da relação $\mathrm{C} / \mathrm{N}$, observaram o aumento da concentração de micélio e conseqüente aumento da viscosidade do líquido, resultando na diminuição da velocidade de utilização de oxigênio em um fermentador de $650 \mathrm{~mL}$, operado em batelada alimentada com recirculação.

Apesar do meio utilizado por Garcia et al. (2000) possuir maior disponibilidade de carbono em relação ao nitrogênio, a proporção $\mathrm{C} / \mathrm{N}$ foi menor que às empregadas nos trabalhos de Kapdan e Kargi (2002) e Sankapal e Kulkarni (2002) e, durante 7 dias de 
experimento em batelada, não foi relatado problema com o crescimento excessivo de biomassa no sistema.

Diferentemente do trabalho de Garcia et al. (2000), nesta pesquisa o menor crescimento dos fungos ocorreu quando a relação $\mathrm{C} / \mathrm{N}$ foi de 1 , ou seja, com carbono e nitrogênio presentes no meio na mesma proporção. Quando a glicose deixou de ser adicionada à água residuária, passando a relação $\mathrm{C} / \mathrm{N}$ a 0,5 , a produção de biomassa foi maior, indicando que sua ausência do meio foi prejudicial ao sistema.

Nota-se, portanto, a importância da relação $\mathrm{C} / \mathrm{N}$ e, principalmente, da influência da concentração de carbono sobre o crescimento dos fungos, de modo que para o controle do crescimento exagerado de biomassa, devem ser evitados meios com limitação carbono. Devem ser utilizados meios nos quais a concentração de carbono seja superior a de nitrogênio, porém não tão elevada que torne o nitrogênio o elemento limitante para o crescimento dos fungos, exigindo que a água residuária seja balanceada em termos nutricionais.

Com relação ao $\mathrm{pH}$, houve ligeira diminuição do seu valor, observando-se variação de 5,7 a 6,7, no efluente de $\mathrm{R}_{1}$, e de 4,8 a 7,2, no efluente de $\mathrm{R}_{2}$. Assim como na Fase I, nos dias em que concentrações de AGV foram detectadas nos efluentes dos reatores $\mathrm{R}_{1}$ e $\mathrm{R}_{2}$. Nas Figuras 5.28 e 5.29 são mostradas as variações de pH nos efluentes dos reatores $R_{1}$ e $R_{2}$ e, nas Figuras 5.30 e 5.31, as de ácidos graxos voláteis.

No reator $R_{1}$, nos dias $74^{\circ}$ e $81^{\circ}$ e entre os dias $95^{\circ}$ e $118^{\circ}$, quando ocorrem as maiores presenças de ácidos voláteis no efluente, há diminuição do valor do pH. Nos últimos dias da operação do reator na Fase II, o pH se eleva, coincidindo com a ausência de AGV no efluente.

A maior concentração de ácidos voláteis no reator $R_{2}$ ocorreu entre os dias $102^{\circ} \mathrm{e}$ $123^{\circ}$, período no qual se observou diminuição do $\mathrm{pH}$. Até o $88^{-}$dia não foram registradas concentrações de $\mathrm{AGV}$, o que ficou refletido na elevação do valor do $\mathrm{pH}$.

Verificou-se que a produção total de ácidos graxos voláteis, de $20 \mathrm{mg} / \mathrm{L}$ e de $40 \mathrm{mg} / \mathrm{L}$, respectivamente, nos reatores $\mathrm{R}_{1}$ e $\mathrm{R}_{2}$, foi menor nesta fase de operação (sem glicose), em relação à Fase I (com glicose), reforçando que a concentração desses ácidos estariam mais relacionada à presença de glicose no meio.

As variações das concentrações de oxigênio dissolvido são apresentadas nas Figuras 5.32 e 5.33 . 


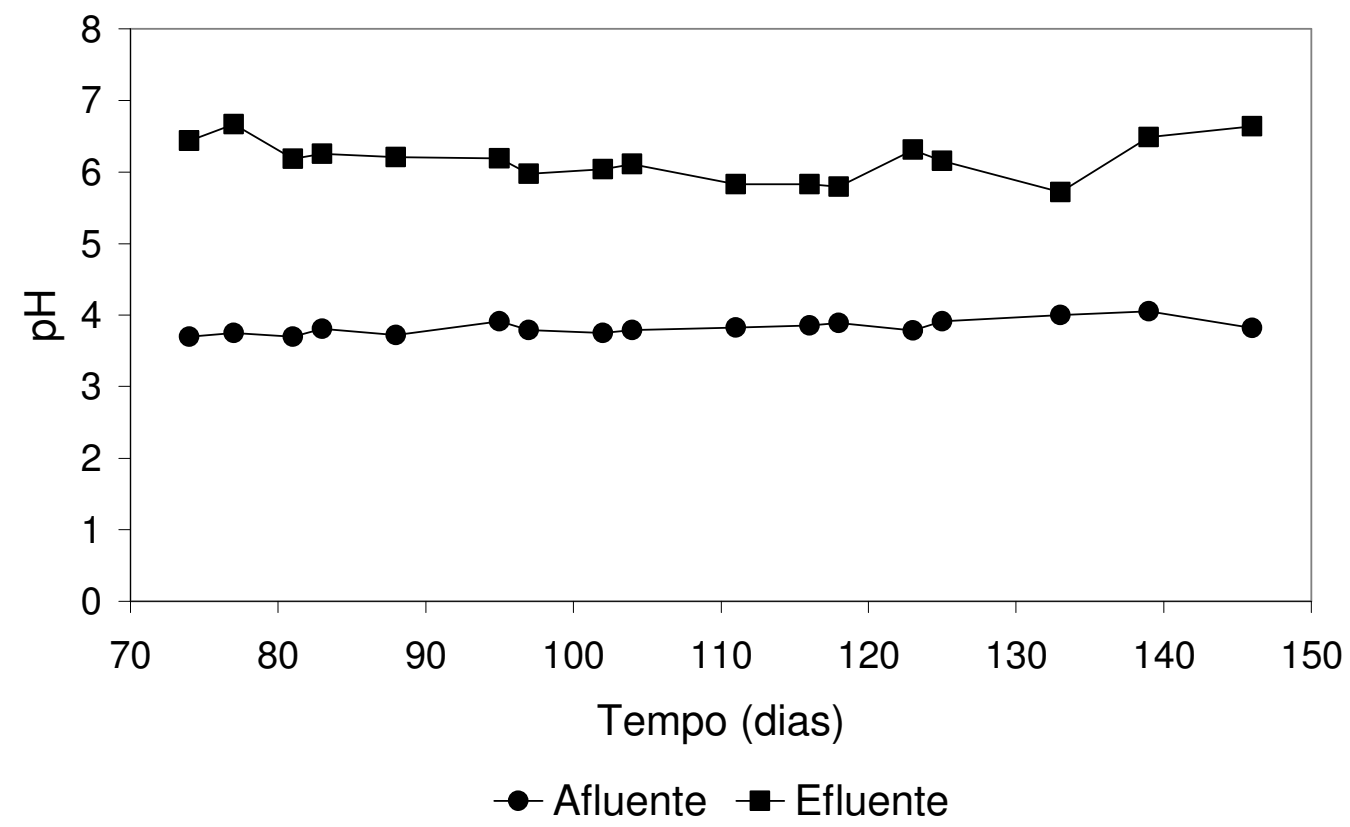

Figura 5.28: Variações do $\mathrm{pH}$ no afluente e efluente do reator com meio suporte de manta de polipropileno $\left(\mathrm{R}_{1}\right)$, no TDH 8 h, Fase II (alimentação sem glicose).

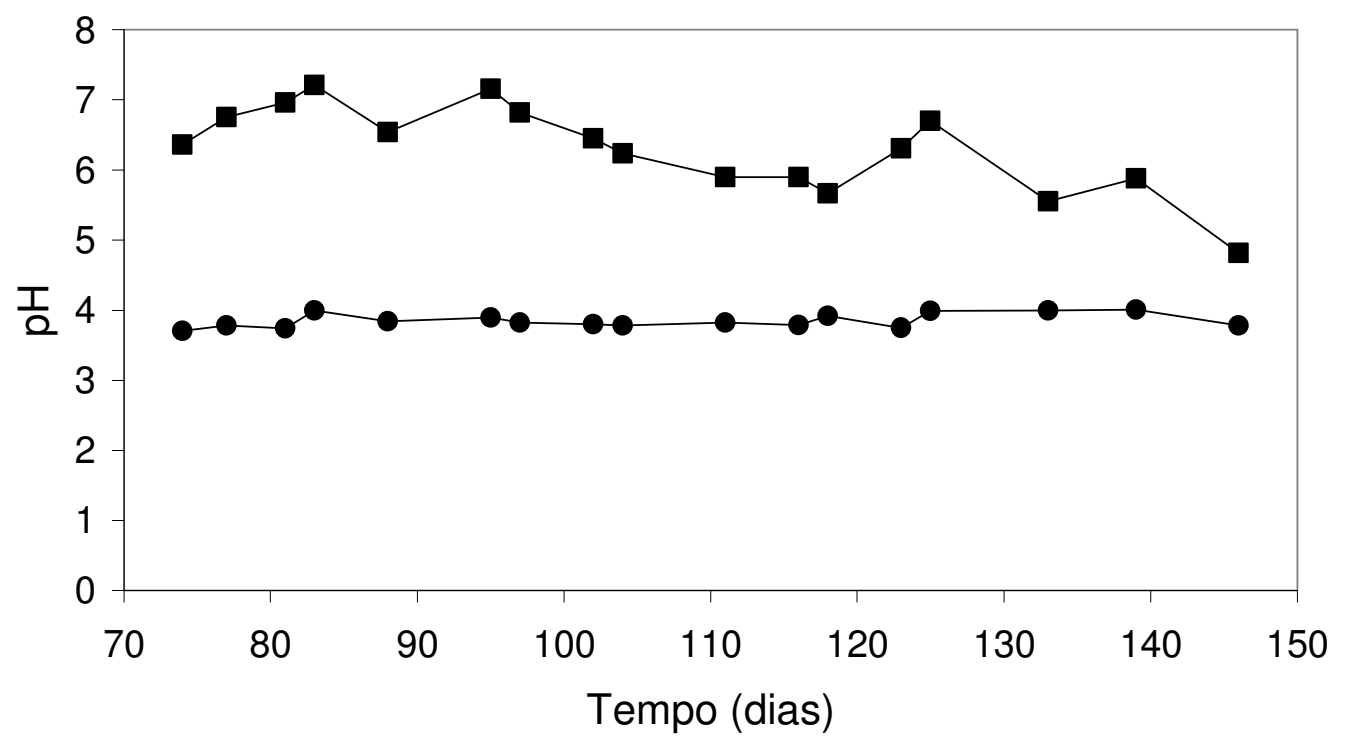

- Afluente - Efluente

Figura 5.29: Variações do $\mathrm{pH}$ no afluente e efluente do reator com meio suporte de espuma de poliuretano $\left(\mathrm{R}_{2}\right)$, no TDH 8 h, Fase II (alimentação sem glicose). 


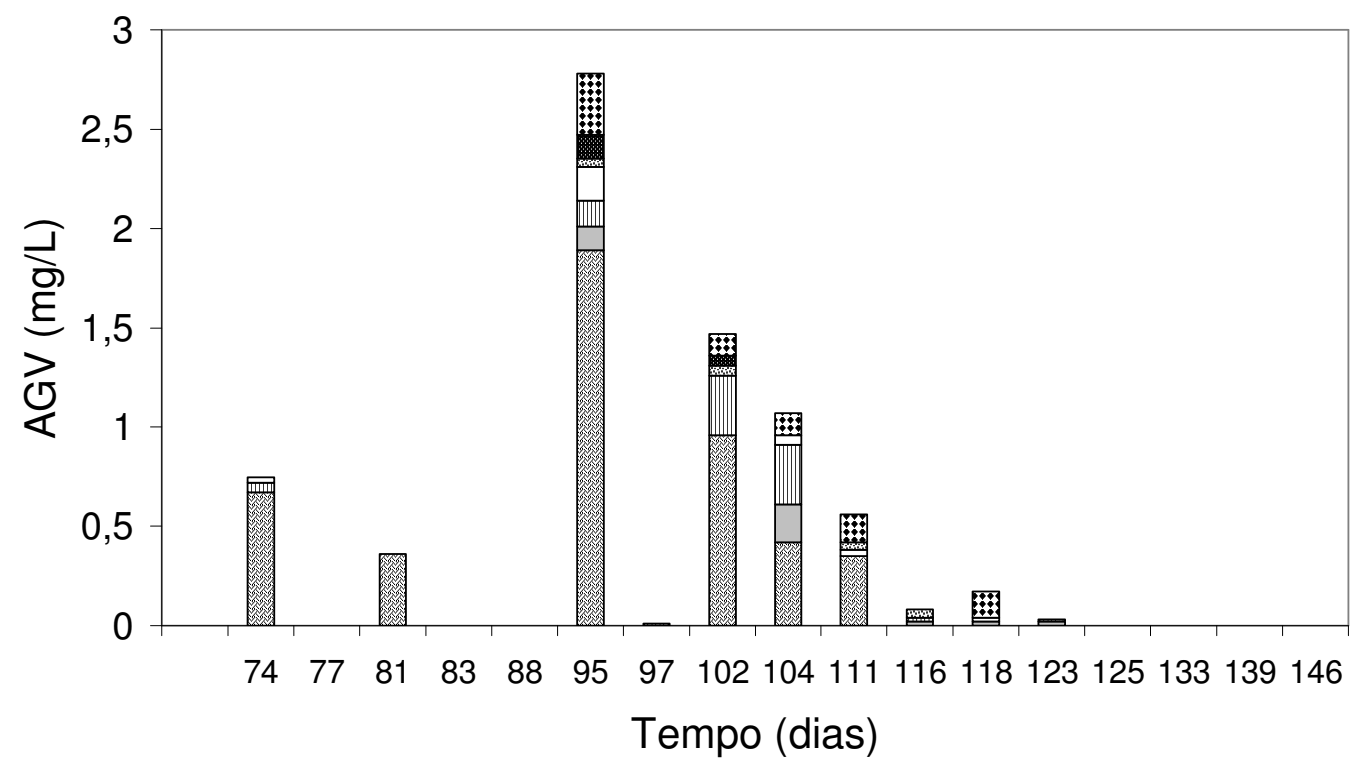

Acético $\square$ Valérico 四Isovalérico $\square$ Butírico 圈 Isobutrico Capróico :

Figura 5.30: Variações das concentrações de AGV no efluente do reator com meio suporte de manta de polipropileno $\left(\mathrm{R}_{1}\right)$, no TDH de $8 \mathrm{~h}$, Fase II (alimentação sem glicose).

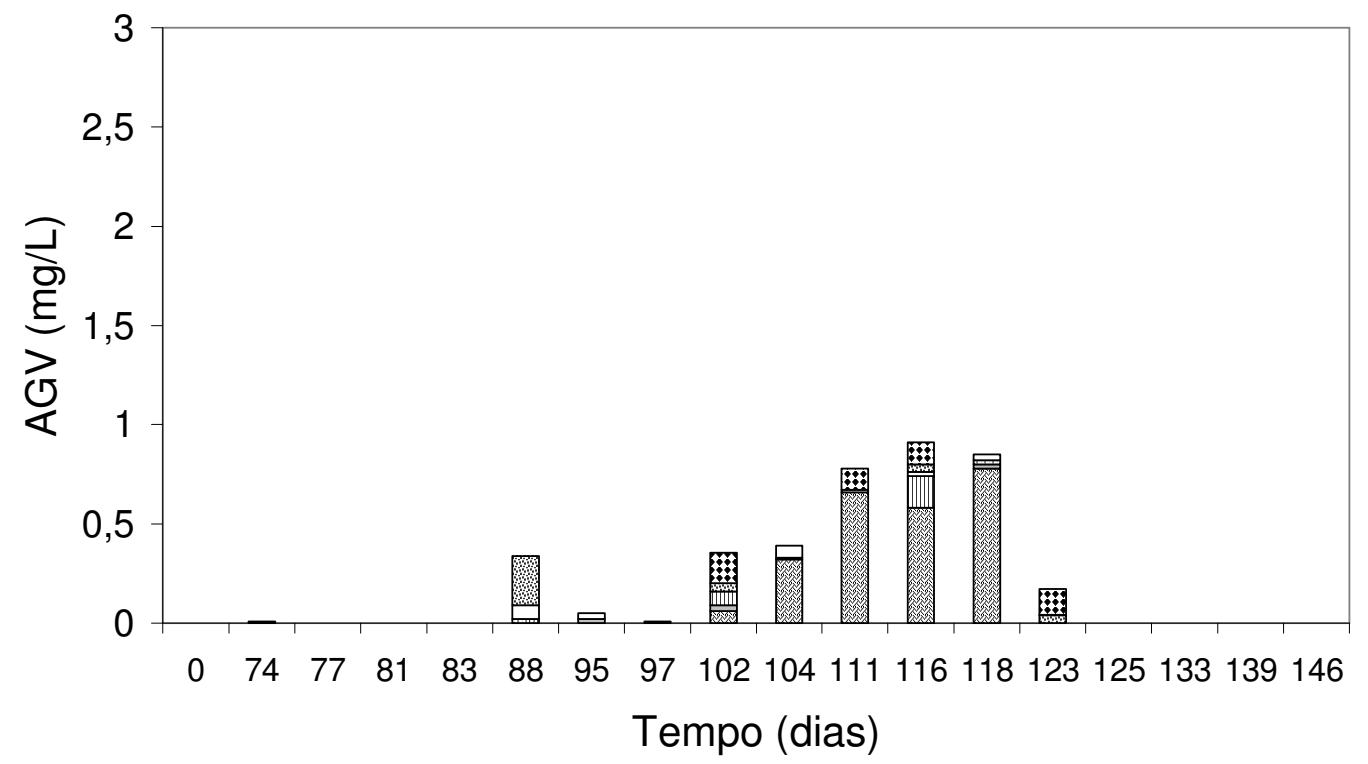

Acético $\square$ Valérico 四Isovalérico $\square$ Butírico 圈 Isobutrico Capróico : Propiônico

Figura 5.31: Variações das concentrações de AGV no efluente do reator com meio suporte de espuma de poliuretano, $\left(\mathrm{R}_{2}\right)$, no TDH de 8 h, Fase II (alimentação sem glicose). 


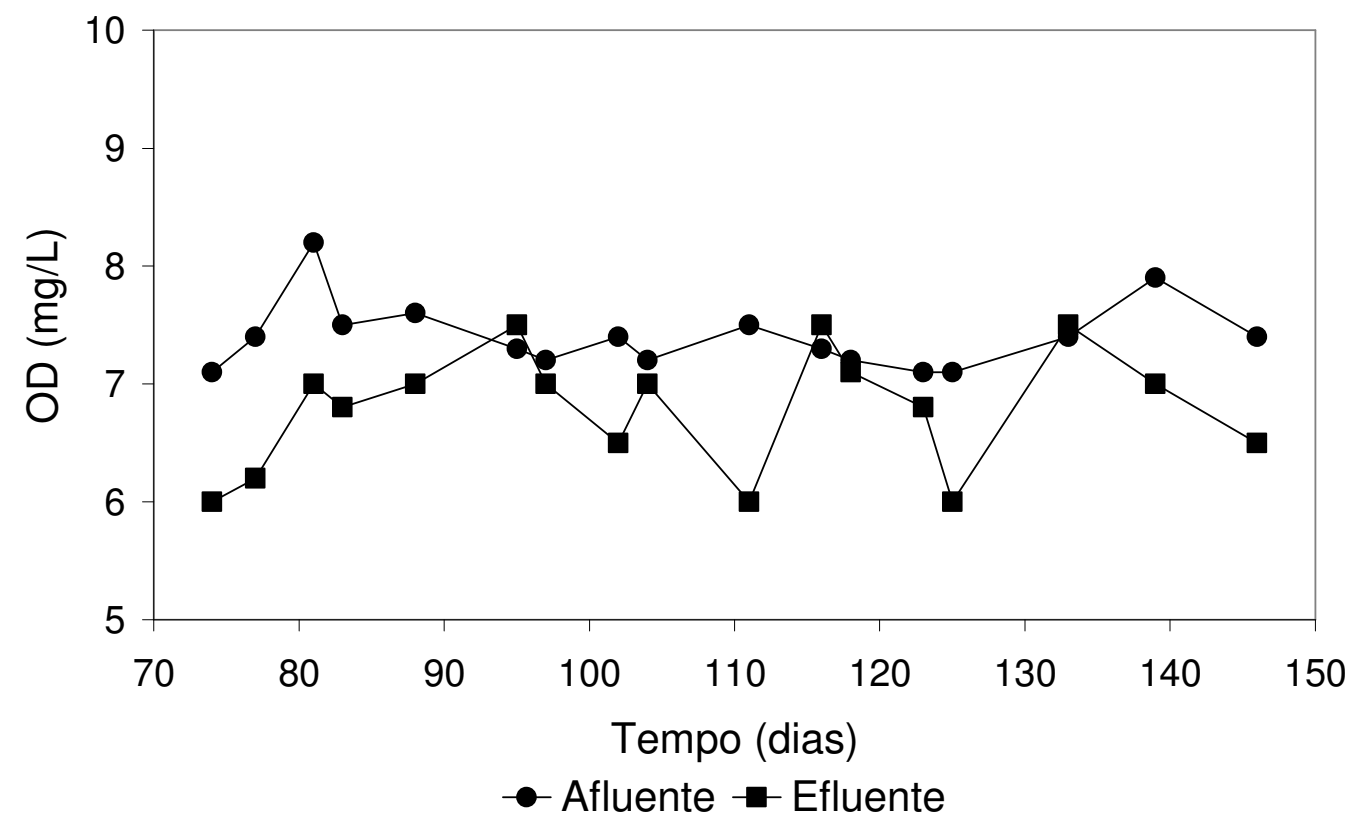

Figura 5.32: Variações das concentrações de OD no afluente e efluente do reator com meio suporte de manta de polipropileno $\left(\mathrm{R}_{1}\right)$, no TDH 8 h, Fase II (alimentação sem glicose)

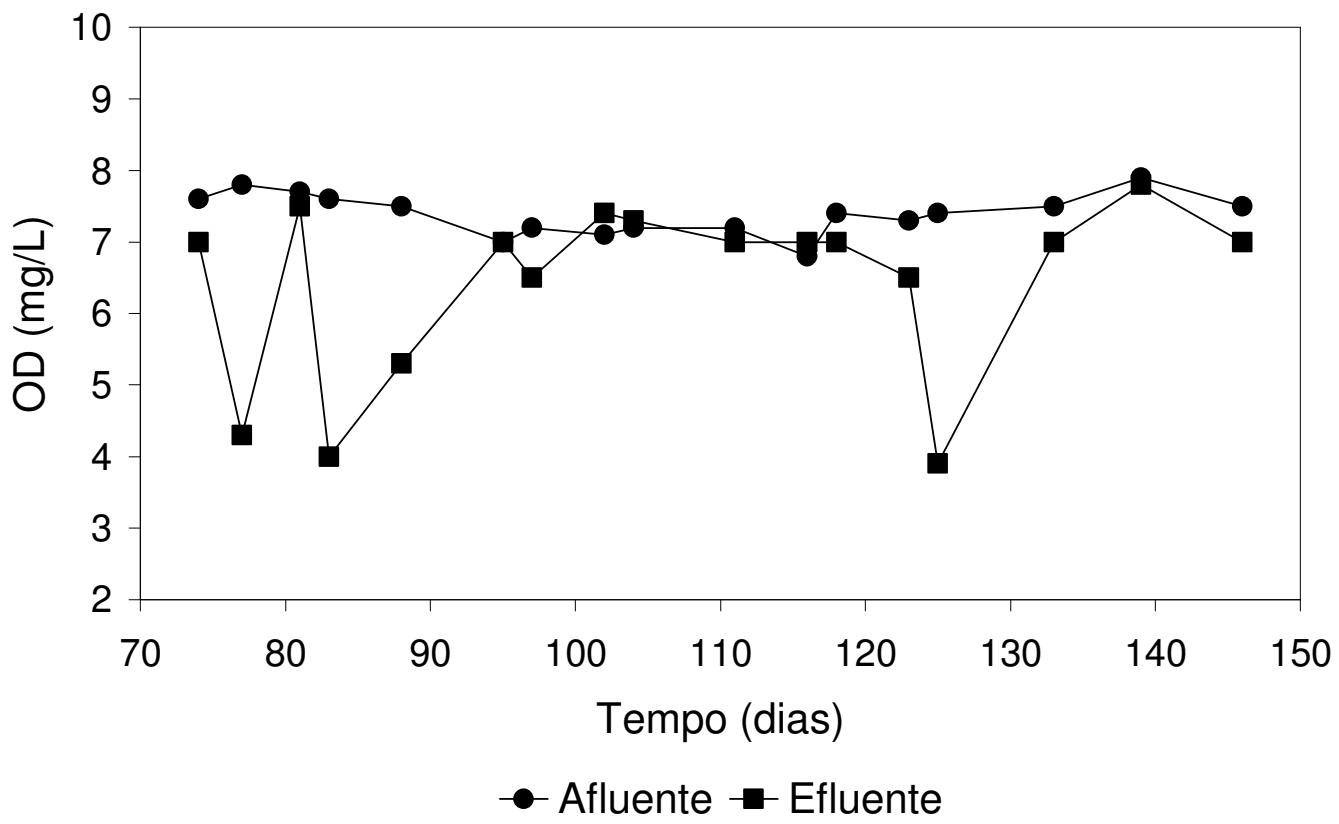

Figura 5.33: Variações das concentrações de OD no afluente e efluente do reator com suporte de espuma de poliuretano $\left(\mathrm{R}_{2}\right)$, no TDH 8 h, Fase II (alimentação sem glicose). 
As concentrações médias de oxigênio dissolvido no efluente dos reatores $R_{1}$ e $R_{2}$ foram de $7 \mathrm{mg} / \mathrm{L} \pm 1$ e $6 \mathrm{mg} / \mathrm{L} \pm 1$, respectivamente. As elevações das concentrações médias de OD em relação às da Fase I foram atribuídas às desobstruções mais freqüentes, realizadas no meio suporte destes reatores, principalmente, no reator com meio suporte de espuma $\left(\mathrm{R}_{2}\right)$.

Verificou-se que, no reator $\mathrm{R}_{2}$, concentrações de oxigênio dissolvido em torno de $4 \mathrm{mg} / \mathrm{L}$, resultaram em remoções mais baixas de matéria orgânica solúvel, de $69 \%$ e $51 \%$, respectivamente, no $88^{\circ}$ e $125^{\circ}$ dia. Em contrapartida, no reator $\mathrm{R}_{1}$, não foram observadas grandes perdas de eficiência de remoção de matéria orgânica solúvel e a menor concentração de oxigênio dissolvido presente no meio foi de $6 \mathrm{mg} / \mathrm{L}$.

Embora os fungos não sejam muito exigentes quanto ao nível oxigênio, observouse, na presente fase de operação, que concentrações mais baixas de oxigênio dissolvido $(\leq 4 \mathrm{mg} / \mathrm{L})$, acarretaram em perda de eficiência no tratamento da água residuária, devido à maior limitação de transferência de massa causada pelo aumento da espessura do biofilme.

Com relação à temperatura, a operação dos reatores ocorreu em faixa entre $16,5^{\circ} \mathrm{C}$ a $26,0^{\circ} \mathrm{C}$, no ambiente onde se encontravam instalados. Também nesse ensaio, aparentemente, a variação da temperatura não influenciou na eficiência de remoção de fenol dos reatores com fungos, praticamente total durante o período de operação.

\subsubsection{Operação dos reatores nos TDH de $4 \mathrm{~h}$.}

As concentrações de matéria orgânica, medida em DQO, no afluente e efluente dos reatores com manta de polipropileno $\left(\mathrm{R}_{1}\right)$ e espuma de poliuretano $\left(\mathrm{R}_{2}\right)$ são mostradas, respectivamente, nas Figuras 5.34 e 5.35. As variações da eficiência de remoção de matéria orgânica são apresentadas nas Figuras 5.36 e 5.37.

Para o tempo de detenção hidráulica de 4 h, as eficiências médias de remoção de matéria orgânica da água residuária, medida em DQO solúvel, em relação ao tempo de detenção hidráulica anterior foram menores, atingindo apenas $48 \% \pm 14$ e $40 \% \pm 15$, respectivamente, para $R_{1}$ e $R_{2}$. As menores remoções de matéria orgânica foram de $13 \%$ (294 ${ }^{\circ}$ dia) e $2 \%$ ( $237^{\circ}$ dia), respectivamente, para $R_{1}$ e $R_{2}$. 


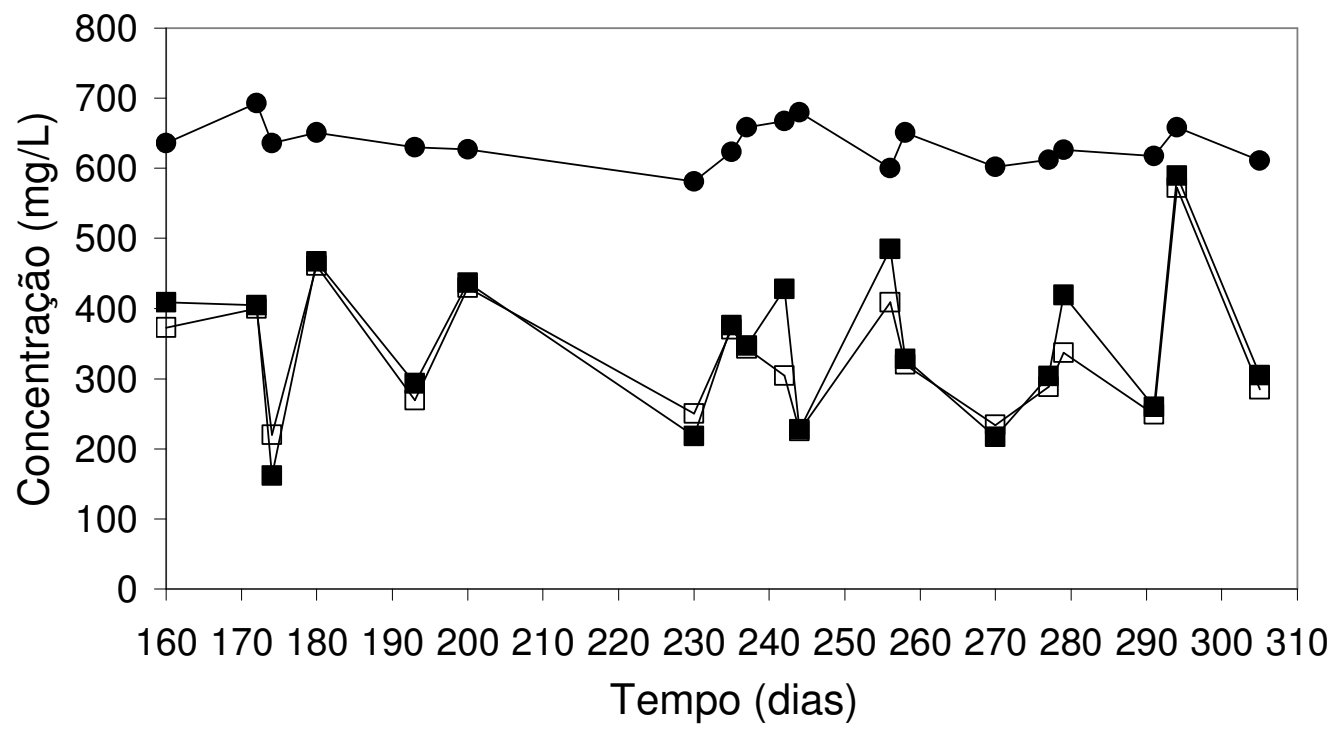

- Afluente - Efluente Bruto $\square$ Efluente Filtrado

Figura 5.34: Variação da concentração de matéria orgânica, medida em DQO, do afluente e efluente do reator com manta de polipropileno $\left(\mathrm{R}_{1}\right)$, no TDH de $4 \mathrm{~h}$.

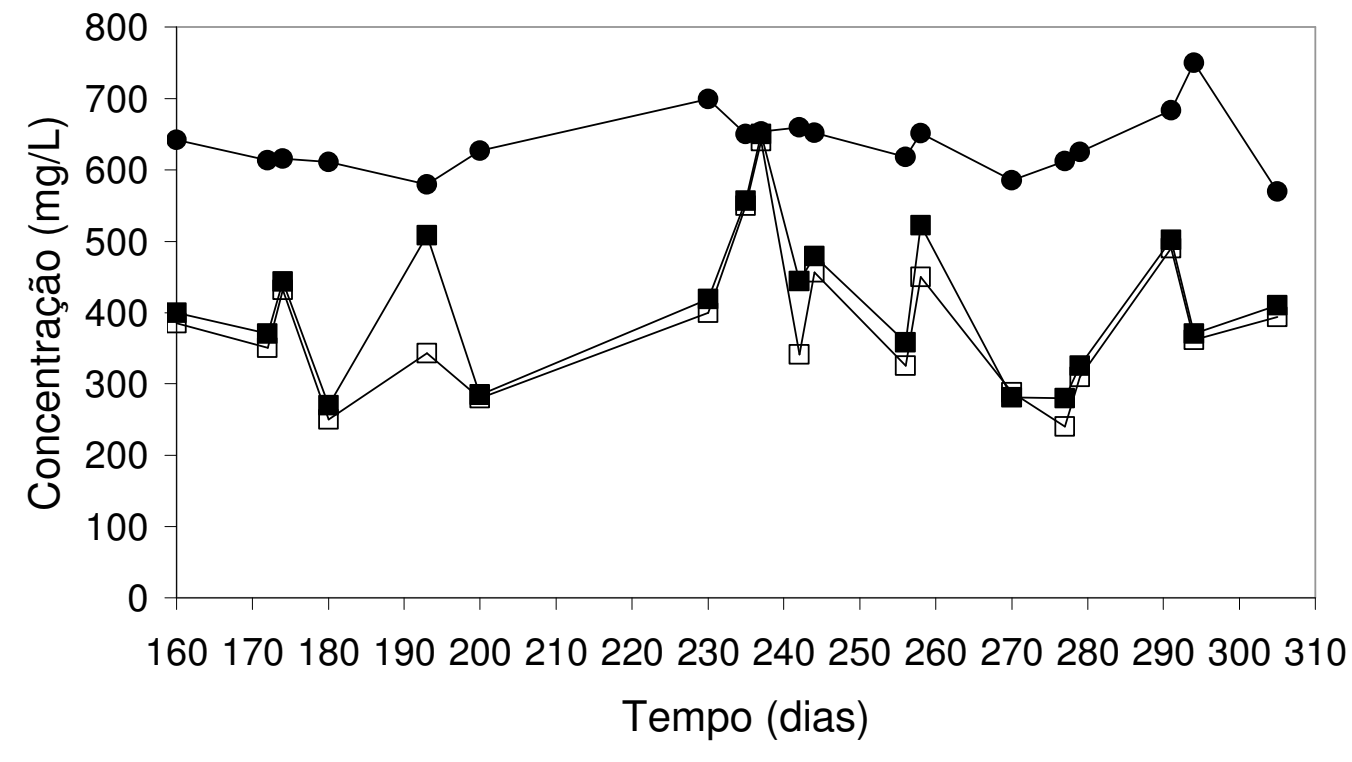

- Afluente -Efluente Bruto $\square$ Efluente Filtrado

Figura 5.35: Variação da concentração de matéria orgânica, medida em DQO, do afluente e efluente do reator com espuma de poliuretano $\left(\mathrm{R}_{2}\right)$, no TDH de $4 \mathrm{~h}$. 


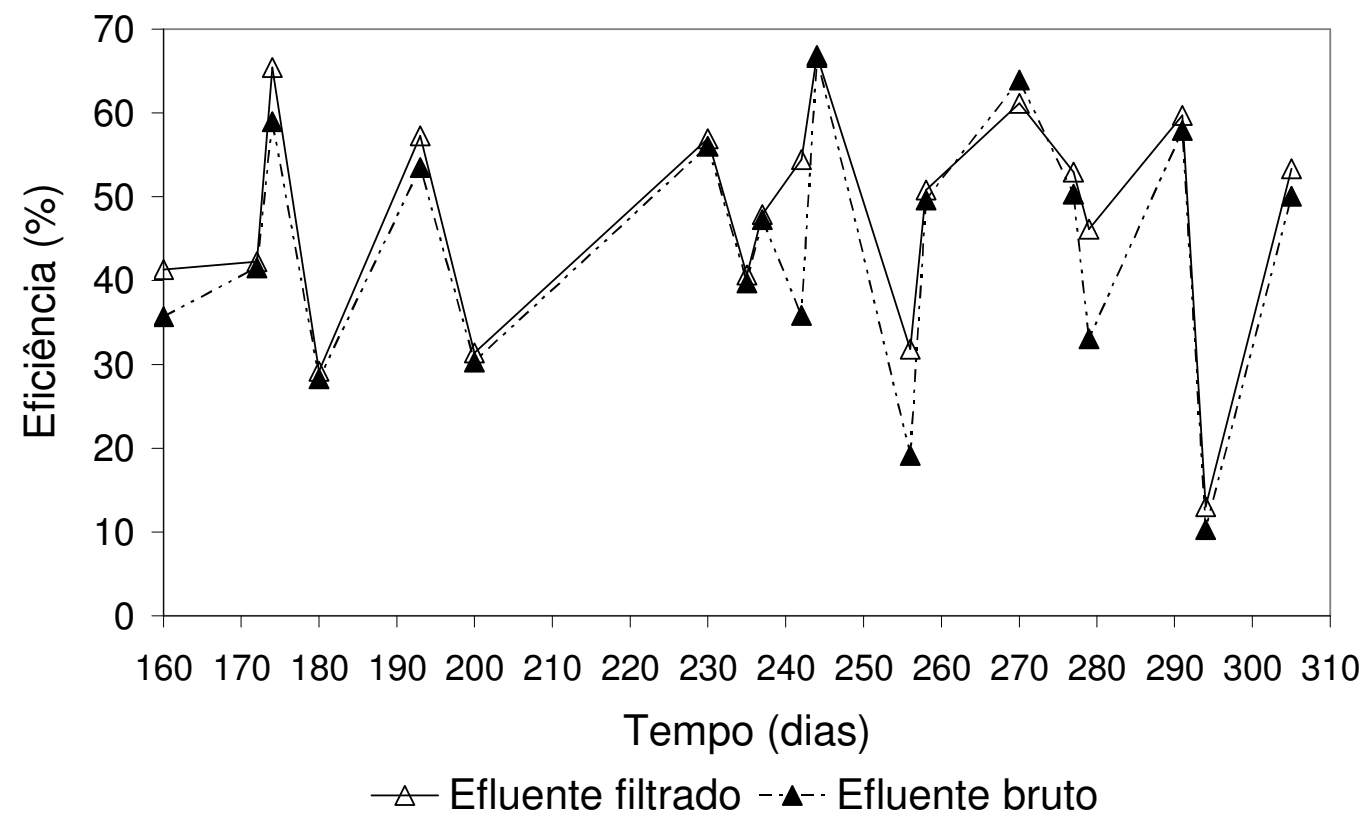

Figura 5.36: Variações das eficiências de remoção da matéria orgânica, medida em DQO, do afluente e efluente do reator com manta de polipropileno $\left(\mathrm{R}_{1}\right)$, no TDH de $4 \mathrm{~h}$.

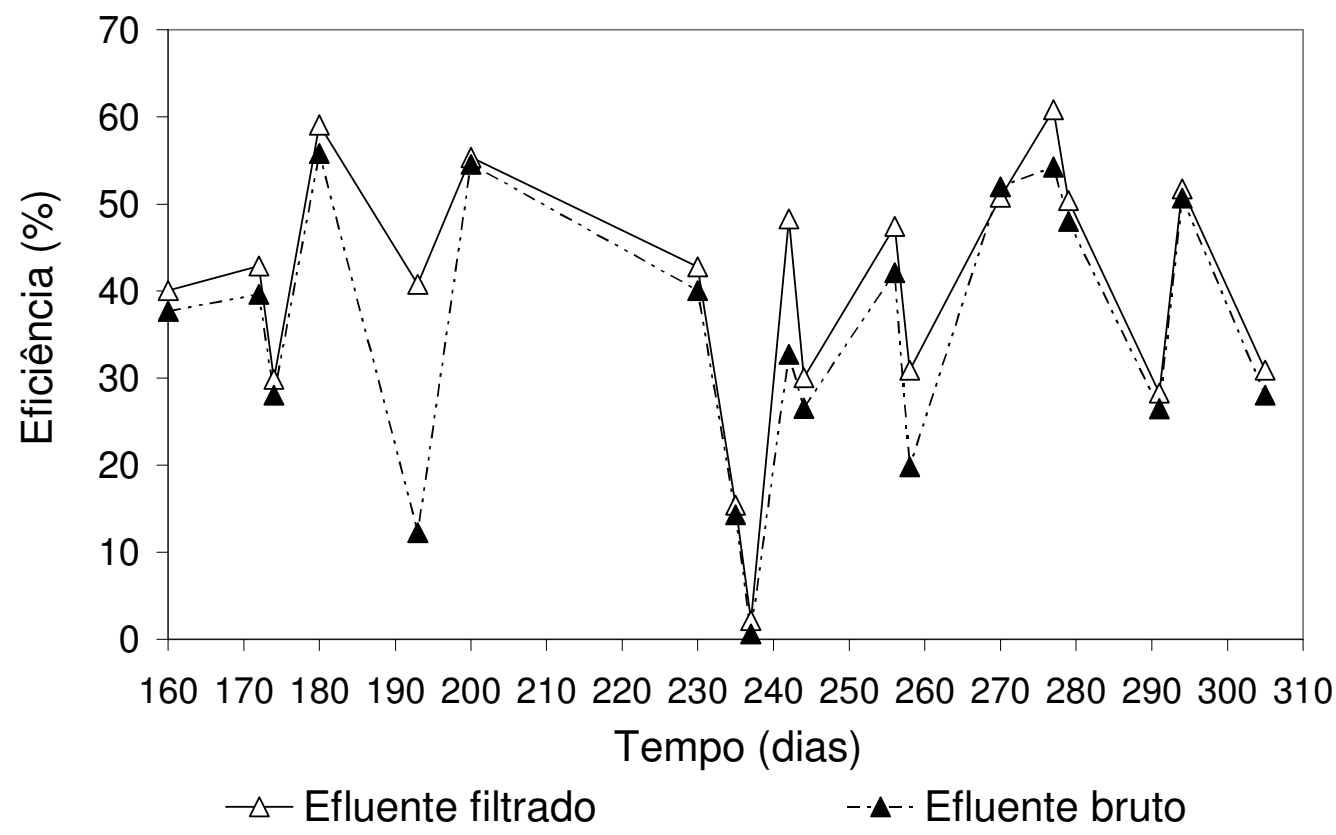

Figura 5.37: Variações das eficiências de remoção da matéria orgânica, medida em DQO, do afluente e efluente do reator com espuma de poliuretano $\left(\mathrm{R}_{2}\right)$, no TDH de $4 \mathrm{~h}$. 
O reator com meio suporte de manta de polipropileno $\left(\mathrm{R}_{1}\right)$ foi o que apresentou a maior remoção pontual de matéria orgânica, em termos de DQO solúvel, de $67 \%$ (244 dia), enquanto a máxima remoção pontual de matéria orgânica registrada para o efluente filtrado do reator com meio suporte de espuma de poliuretano $\left(\mathrm{R}_{2}\right)$ foi de $61 \%\left(277^{\mathrm{o}}\right.$ dia). As remoções de fenol acompanharam às de DQO solúvel, sendo a maior remoção de $70 \%$ e a menor, de $7 \%$, pois a única fonte de carbono da qual os fungos dispuseram foi o fenol.

Da mesma forma, para o reator $\mathrm{R}_{2}$, a remoção máxima de fenol, de $68 \%$ (277ํㅜㅇ dia), e a menor, de 4\% (237 $\mathrm{dia})$, também acompanharam a maior e menor remoção de matéria orgânica neste reator, respectivamente, de $61 \%$ e $2 \%$.

As variações das concentrações de fenol no afluente e efluente dos reatores $R_{1} \mathrm{e}$ $\mathrm{R}_{2}$ são apresentadas nas Figuras 5.38 e 5.39. Ambos os reatores alcançaram eficiências de remoção de fenol similares, $50 \%\left(\mathrm{R}_{1}\right)$ e $48 \%\left(\mathrm{R}_{2}\right)$.

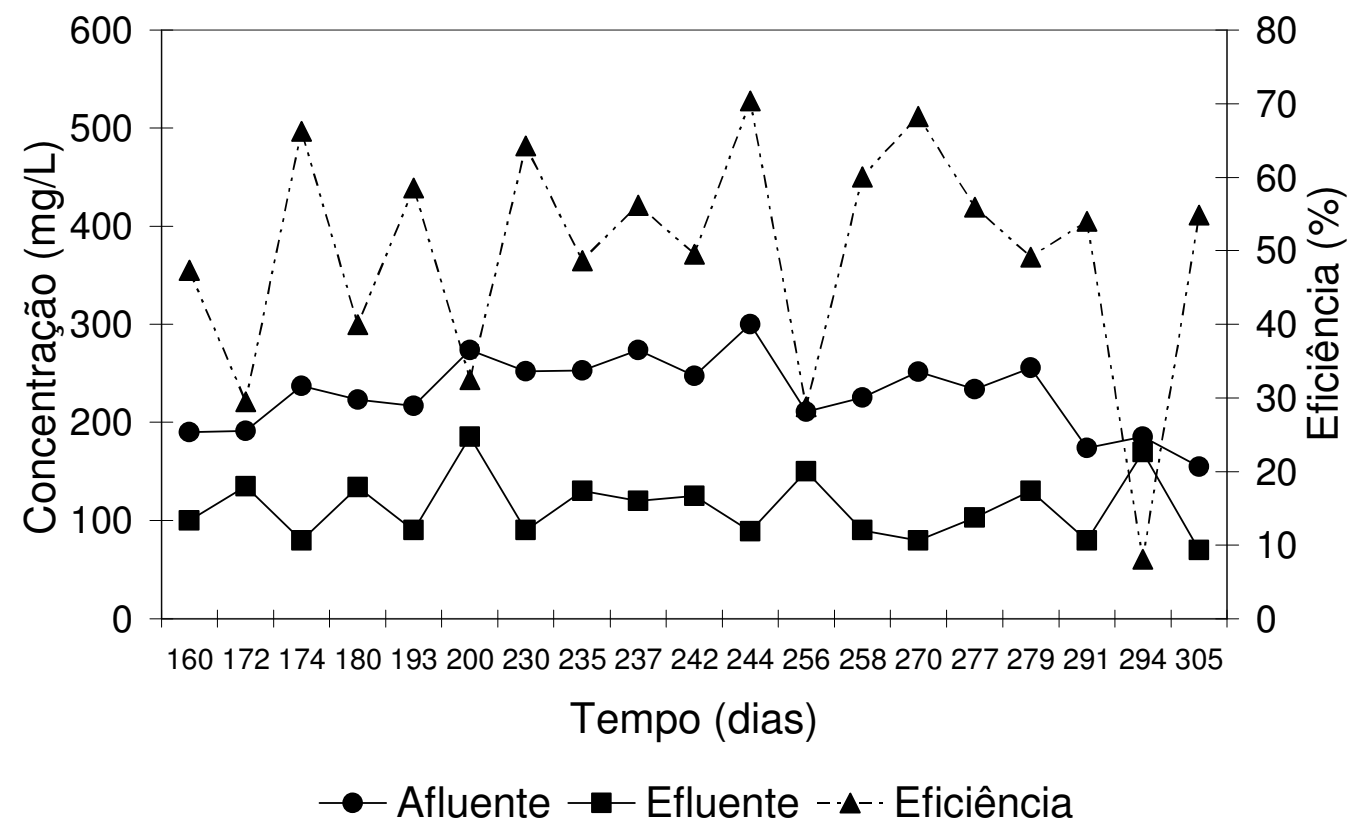

Figura 5.38: Variações das concentrações de fenol no afluente e efluente do reator com manta de polipropileno $\left(\mathrm{R}_{1}\right)$, no TDH de $4 \mathrm{~h}$. 


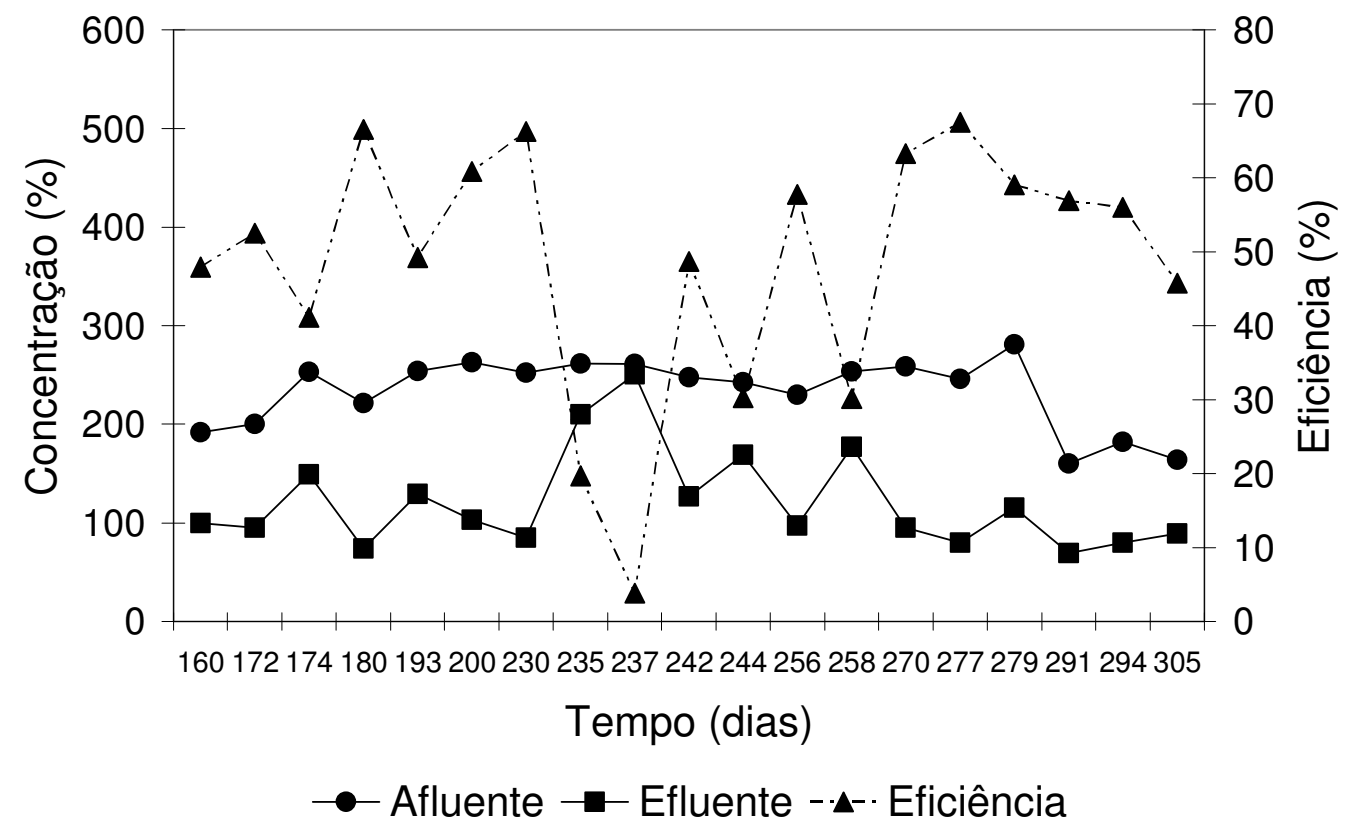

Figura 5.39: Variações das concentrações de fenol no afluente e efluente do reator com espuma de poliuretano $\left(\mathrm{R}_{2}\right)$, no TDH de $4 \mathrm{~h}$.

As remoções de matéria orgânica no efluente bruto foram de $44 \%\left(\mathrm{R}_{1}\right)$ e $35 \%$ $\left(R_{2}\right)$, cerca de $10 \%$ abaixo da eficiência média de remoção no efluente filtrado, devido ao maior desprendimento de biomassa do meio suporte causado pela vazão resultante deste tempo de detenção hidráulica.

A maior vazão desse novo TDH provocou grande deslocamento ascendente do meio suporte dos reatores. Para solucionar o problema, a haste, usada como guia para os contentores, foi fixada na parte superior dos reatores, impedindo o deslocamento do meio suporte.

Com a diminuição do TDH para $4 \mathrm{~h}$, os microrganismos não foram capazes de manter os níveis de eficiência alcançados quando operados com tempo de detenção hidráulica de $8 \mathrm{~h}$, devido ao menor tempo disponível para a utilização do substrato pelo biofilme.

A perda de eficiência do tratamento de águas residuárias relacionadas à diminuição do TDH têm sido observadas por vários autores. Santaella (1999) obteve quase $100 \%$ de remoção de matéria orgânica em um TDH de 17 h, durante o tratamento de água residuária da indústria da castanha de caju por uso de reator com fungos, porém 
com a diminuição do tempo de detenção hidráulica para $8 \mathrm{~h}$, houve perda de eficiência, a qual ficou em torno de $45 \%$.

Sampaio et al. (2004) também observaram perda da eficiência de remoção de matéria orgânica ao utilizarem reator com fungos alimentado com efluente de reator UASB no tratamento de água residuária da indústria de beneficiamento da castanha de caju. No TDH de 4 h, foi alcançada remoção de matéria orgânica $83 \%$, as quais passaram a $74 \%$ e $61 \%$, respectivamente, nos TDH de $2 \mathrm{~h}$ e $1 \mathrm{~h}$. Assim como nesta pesquisa, os autores também associaram a perda de eficiência ao menor tempo de contato entre substrato e microrganismos, impedindo, desta forma, total degradação da matéria orgânica.

As variações das concentrações de oxigênio dissolvido no afluente e efluente dos reatores $\mathrm{R}_{1}$ e $\mathrm{R}_{2}$ são mostradas nas Figuras 5.40 e 5.41 .

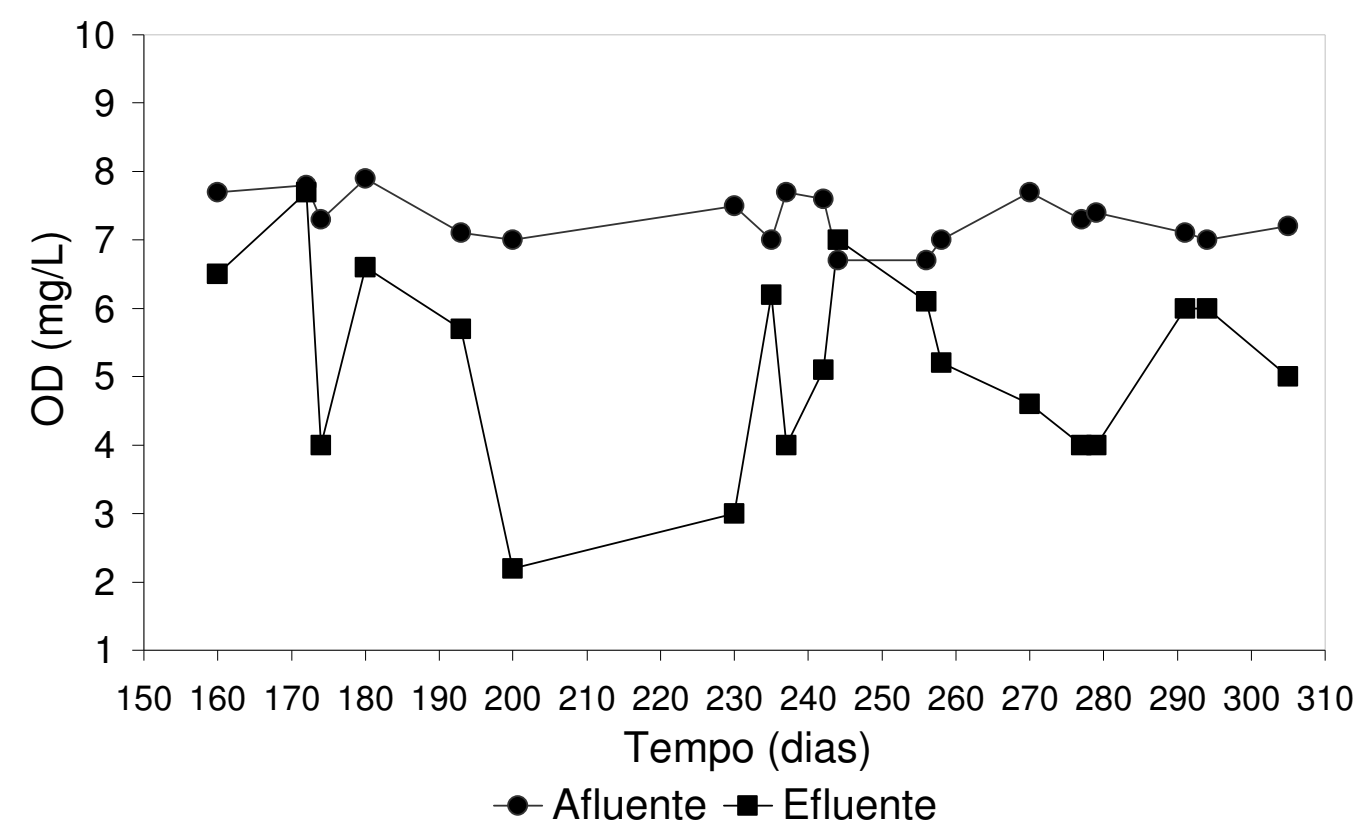

Figura 5.40: Variações das concentrações de OD no afluente e efluente do reator com manta de polipropileno $\left(\mathrm{R}_{1}\right)$, no TDH de $4 \mathrm{~h}$. 


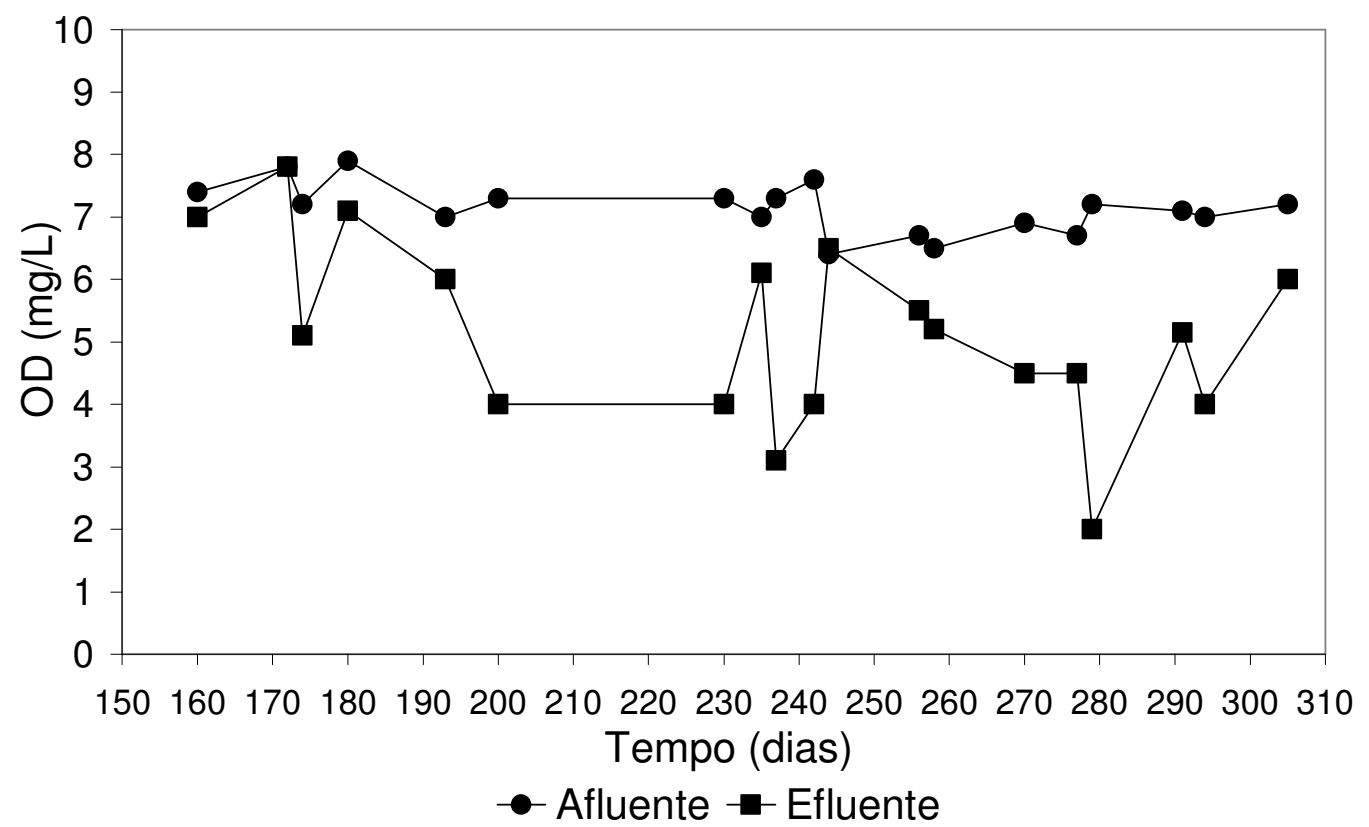

Figura 5.41: Variações das concentrações de OD no afluente e efluente do reator com espuma de poliuretano $\left(\mathrm{R}_{2}\right)$, no TDH de $4 \mathrm{~h}$.

A concentração média de oxigênio dissolvido nos efluentes dos reatores $R_{1}$ e $R_{2}$ foi de $5 \mathrm{mg} / \mathrm{L} \pm 1$. A menor concentração média de oxigênio dissolvido no meio, em ambos os reatores, ocorreu porque a vazão com a qual a água residuária passava pelos reatores se sobrepunha à da aeração, impedindo, assim, que houvesse entrada mais intensa de ar.

Com relação ao $\mathrm{pH}$, de maneira geral, verificou-se ligeiro aumento do $\mathrm{pH}$ em relação ao tempo de detenção hidráulica de $8 \mathrm{~h}$. Esta elevação do $\mathrm{pH}$ pode ter sido influenciada pela menor concentração de ácidos graxos voláteis presente no meio, as quais se apresentaram em níveis não detectáveis pelo método $(<0,75 \mathrm{mg} / \mathrm{L})$.

Os efluentes apresentaram pH variando de 6,3 a 7,0, no reator $\mathrm{R}_{1}$, e de 5,43 a 7,34, no reator $\mathrm{R}_{2}$. Nas Figuras 5.42 e 5.43 são apresentadas as variações do pH no afluente e afluente dos reatores $\mathrm{R}_{1}$ e $\mathrm{R}_{2}$. 


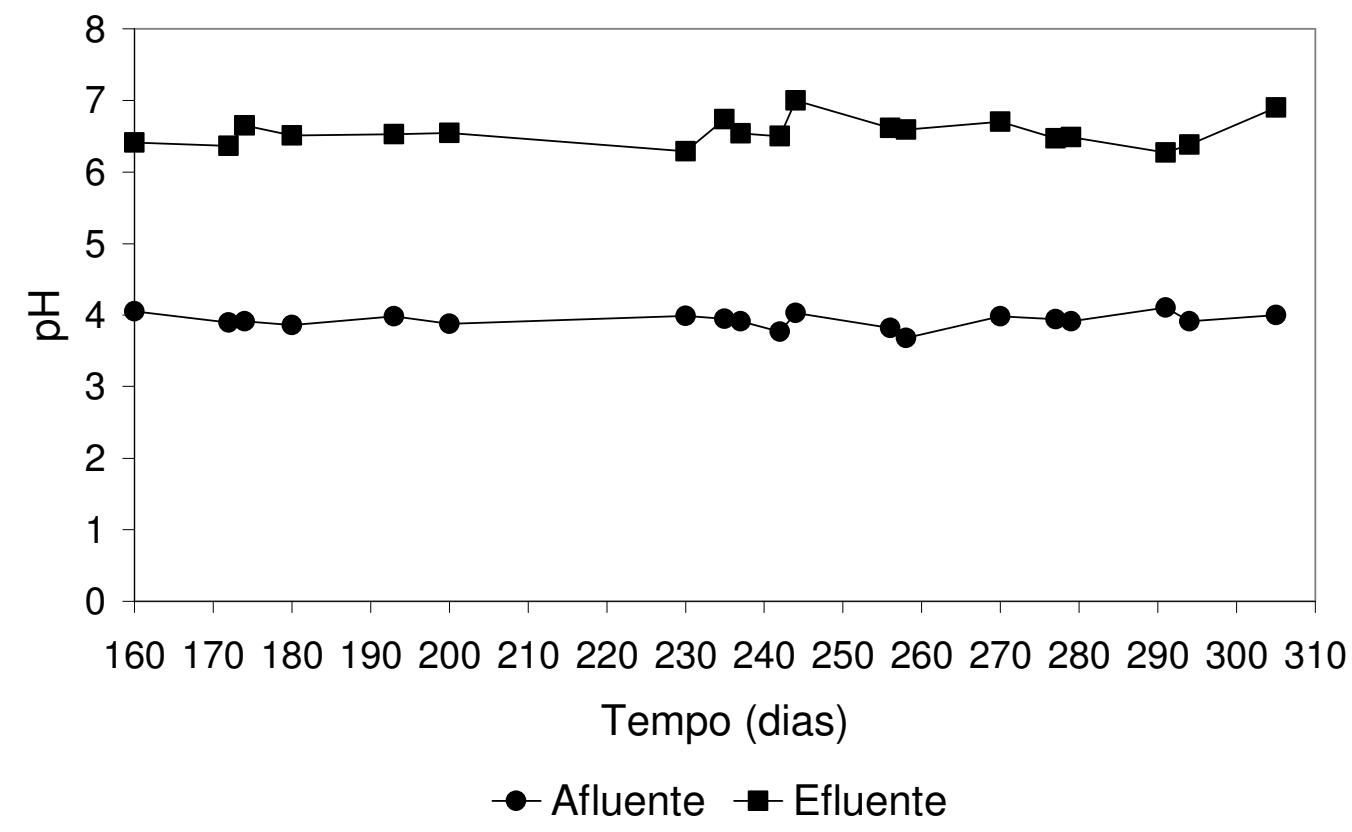

Figura 5.42: Variações do $\mathrm{pH}$ no afluente e efluente do reator com manta de polipropileno $\left(\mathrm{R}_{1}\right)$, no $\mathrm{TDH}$ de $4 \mathrm{~h}$.

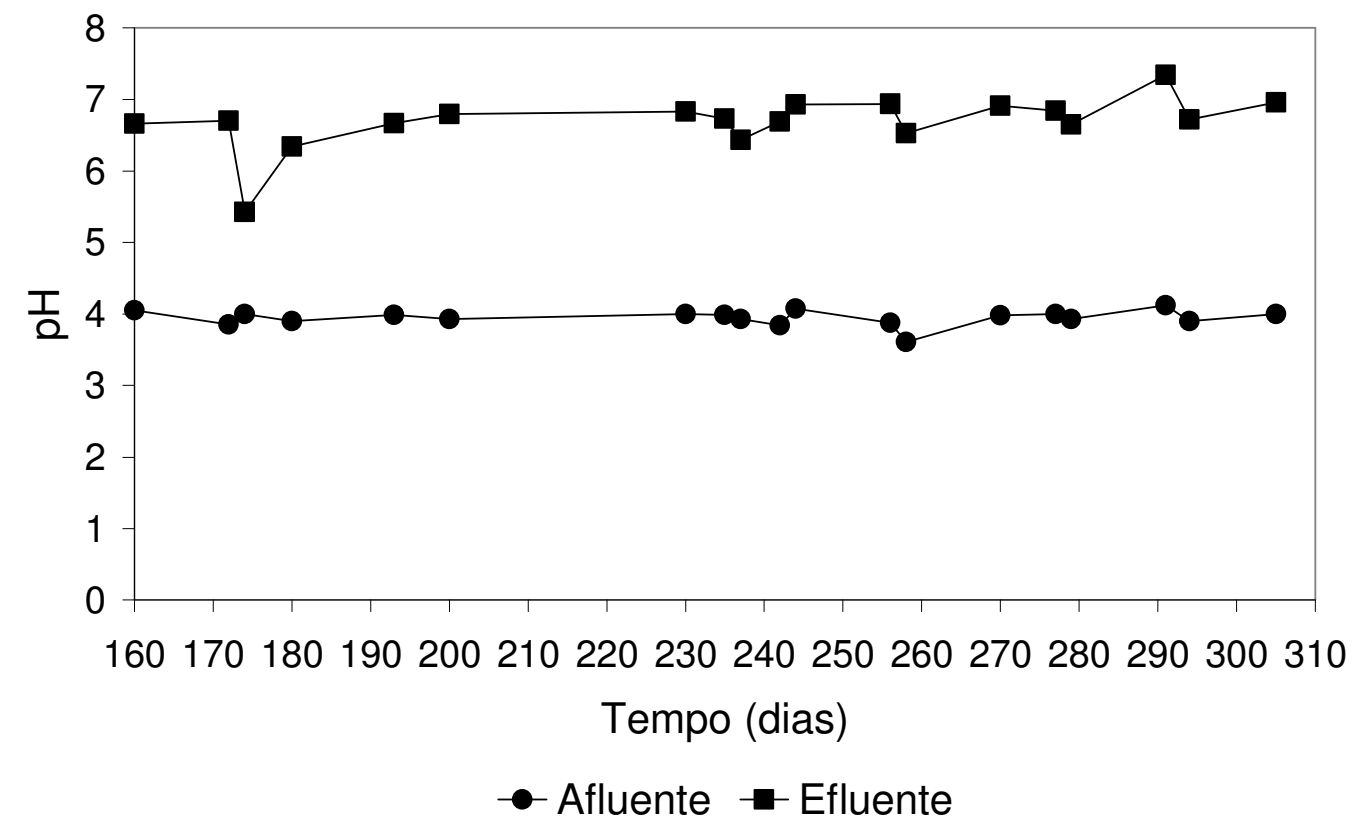

Figura 5.43: Variações do $\mathrm{pH}$ no afluente e efluente do reator com espuma de poliuretano $\left(\mathrm{R}_{2}\right)$, no TDH de $4 \mathrm{~h}$. 
A temperatura ambiente variou de $22^{\circ} \mathrm{C}$ a $27^{\circ} \mathrm{C}$ durante o período de operação do TDH de 4 h, não tendo, aparentemente, causado interferência na perda de eficiência do tratamento da água residuária, sendo que, neste tempo de detenção hidráulica, o fator preponderante para da diminuição da eficiência de remoção de matéria orgânica e fenol foi o menor tempo de contato entre microrganismos e substrato.

\subsubsection{Operação dos reatores TDH de $6 \mathrm{~h}$}

A operação dos reatores sob o TDH de 6 h foi realizada para obtenção de dados sobre a eficiência do tratamento da água residuária sintética com fenol pelos reatores com fungos, em tempo de detenção intermediário entre os estudados ( 8 h e 4 h).

As variações das concentrações de matéria orgânica, medida em DQO, e da eficiência de sua remoção no afluente e efluente são mostradas nas Figuras 5.44 e 5.45 e 5.46 e 5.47, respectivamente, nos reatores $R_{1}$ e $R_{2}$.

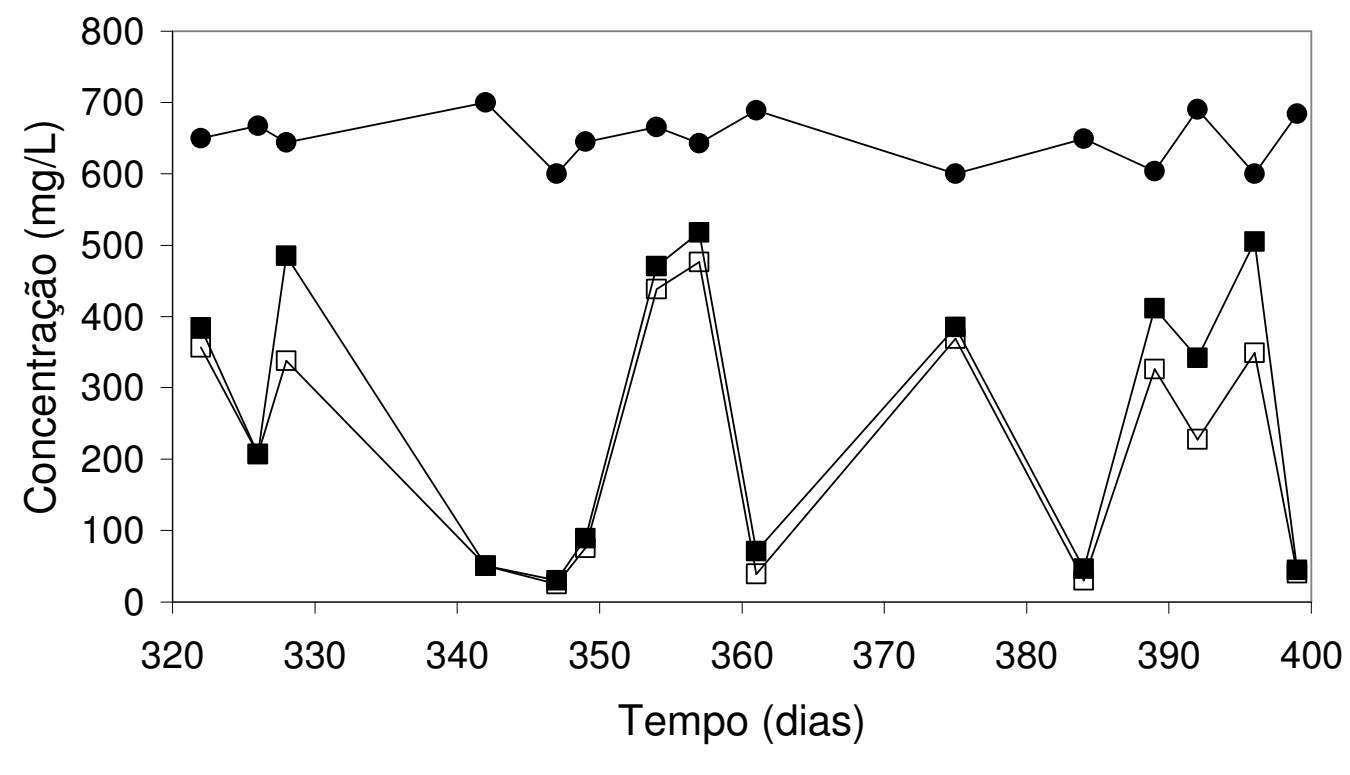

-- Afluente - Efluente bruto $\square$ Efluente filtrado

Figura 5.44: Variações das concentrações de matéria orgânica, medida em DQO, no afluente e efluente do reator com manta de polipropileno $\left(\mathrm{R}_{1}\right)$, no TDH de $6 \mathrm{~h}$. 


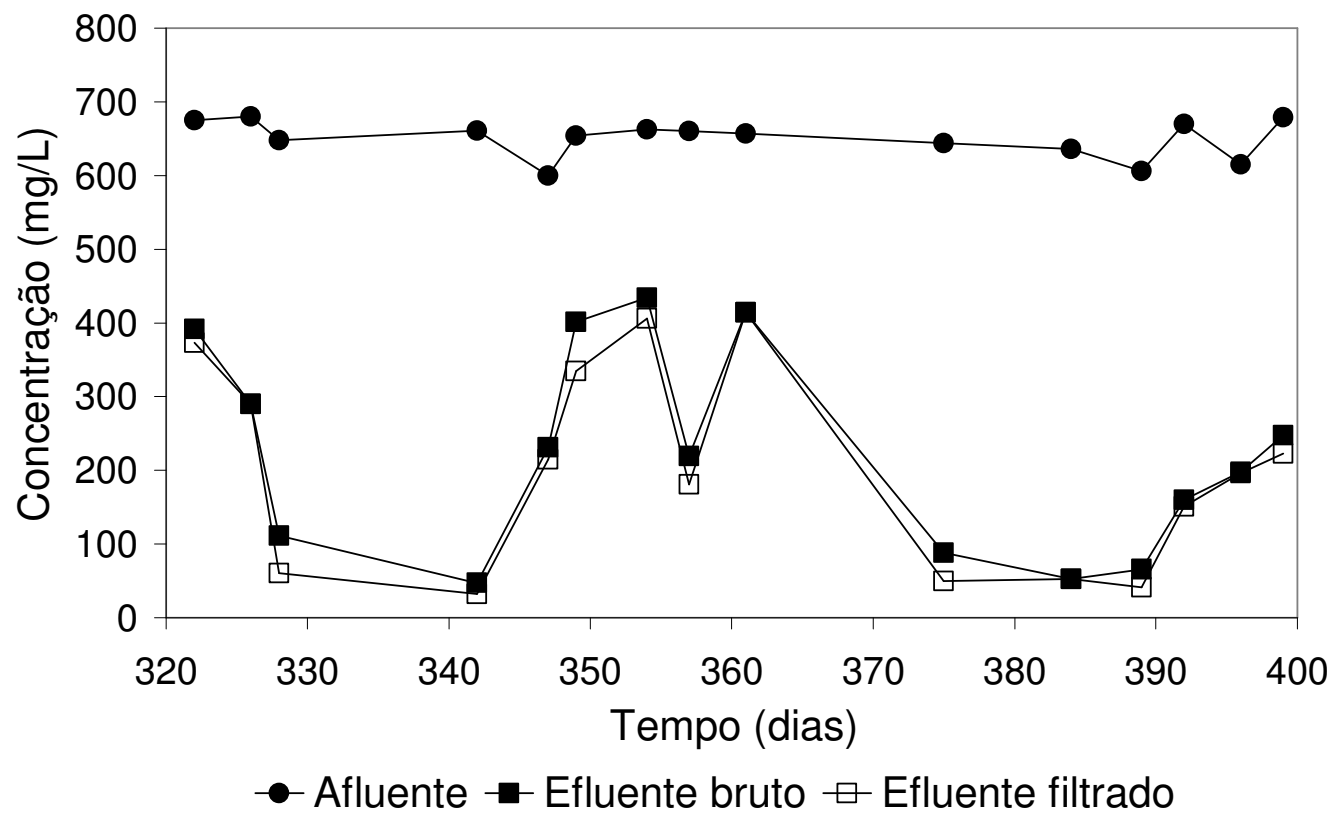

Figura 5.45: Variações das concentrações de matéria orgânica, medida em DQO, no afluente e efluente do reator com espuma de poliuretano $\left(\mathrm{R}_{2}\right)$, no TDH de $6 \mathrm{~h}$.

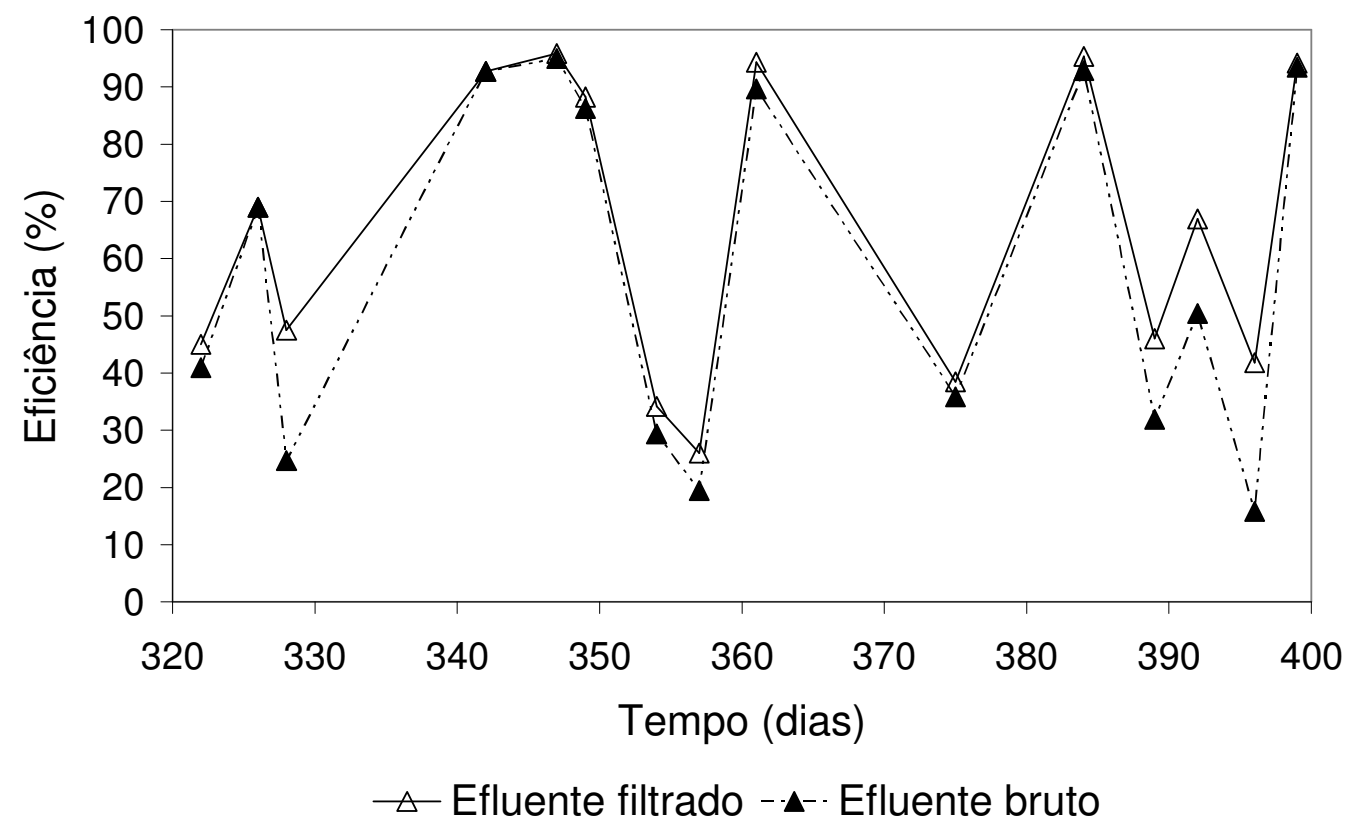

Figura 5.46: Variações das eficiências de remoção da matéria orgânica, medida em DQO, no afluente e efluente do reator com manta de polipropileno $\left(\mathrm{R}_{1}\right)$, no TDH de $6 \mathrm{~h}$. 


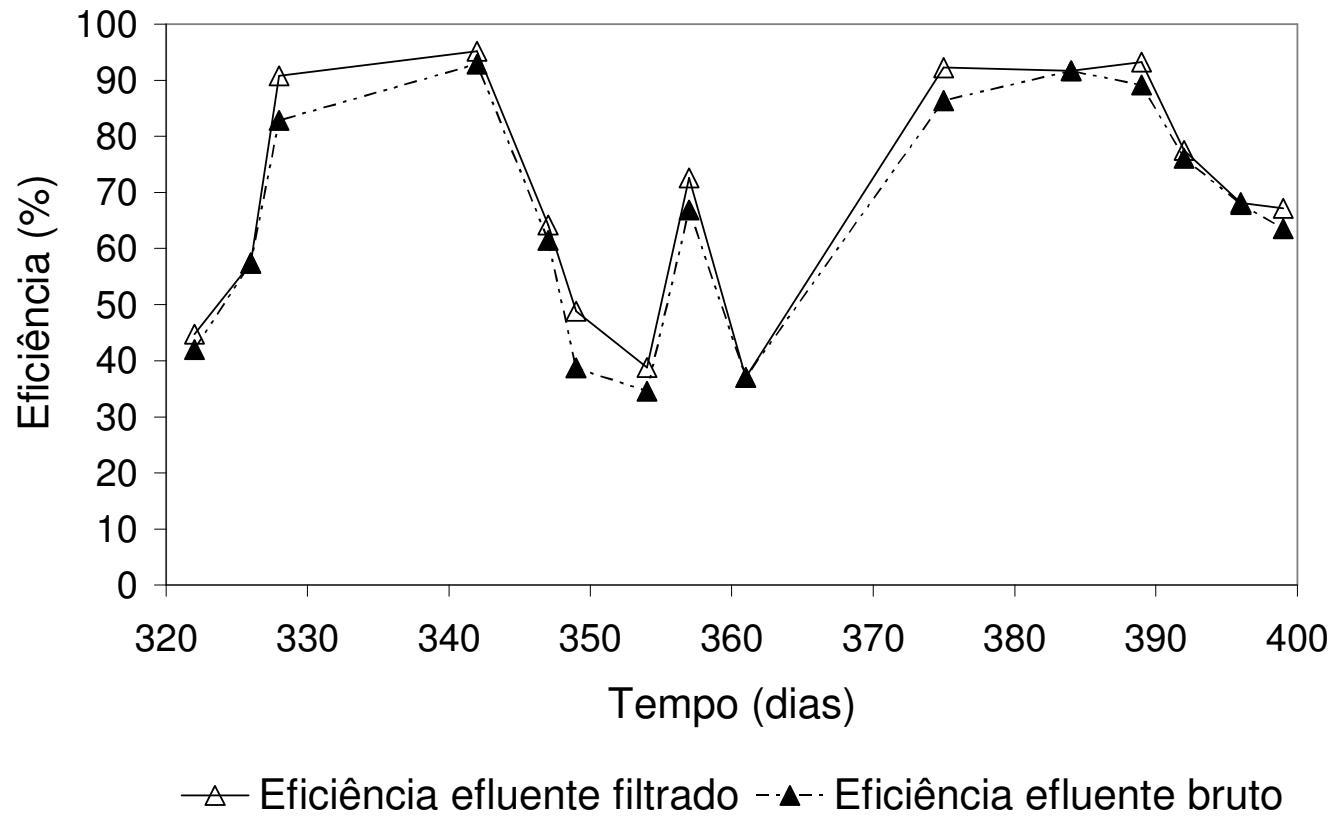

Figura 5.47: Variações das eficiências de remoção da matéria orgânica, medida em DQO, no afluente e efluente do reator com espuma de poliuretano $\left(\mathrm{R}_{2}\right)$, no TDH de $6 \mathrm{~h}$.

Em relação ao tempo de detenção de 4 h, houve aumento na eficiência de remoção de matéria orgânica, sendo que os reatores alcançaram remoções médias de matéria orgânica solúvel muito próximas, de $65 \% \pm 26\left(\mathrm{R}_{1}\right)$ e de $69 \% \pm 21\left(\mathrm{R}_{2}\right)$. No efluente bruto, as remoções médias de matéria orgânica foram de $58 \% \pm 31$ e de $66 \% \pm 21$, percentuais estes superiores aos obtidos no TDH de $4 \mathrm{~h}$, os quais resultaram do menor despendimento de biofilme e seu conseqüente arraste pela vazão resultante do tempo de detenção de hidráulica de $6 \mathrm{~h}$.

Com relação ao fenol, as variações das concentrações são apresentadas nas Figuras 5.48 e 5.49, tendo-se obtido eficiências médias de remoção de $72 \%$ e $78 \%$, respectivamente, nos reatores $R_{1}$ e $R_{2}$, apresentando uma melhora da eficiência do tratamento da água residuária em relação ao tempo de detenção hidráulica de $4 \mathrm{~h}$. No reator $\mathrm{R}_{1}$, a remoção máxima de $99 \%$, atingida no $342^{\circ}, 347^{\circ} 384^{\circ}$ e $384^{\circ}$ dias, refletiuse nos resultados de remoção de matéria orgânica registrados nesses dias, de 93\%, 96\%, $95 \%$ e $94 \%$, respectivamente. A maior remoção de fenol, no reator $\mathrm{R}_{2}$, foi de $95 \%$, nos $328^{\circ}, 342^{\circ}, 375^{\circ}$ e $384^{\circ}$ dias, e, assim como no reator $R_{1}$, resultou em eficiência elevada de remoção de matéria orgânica. 


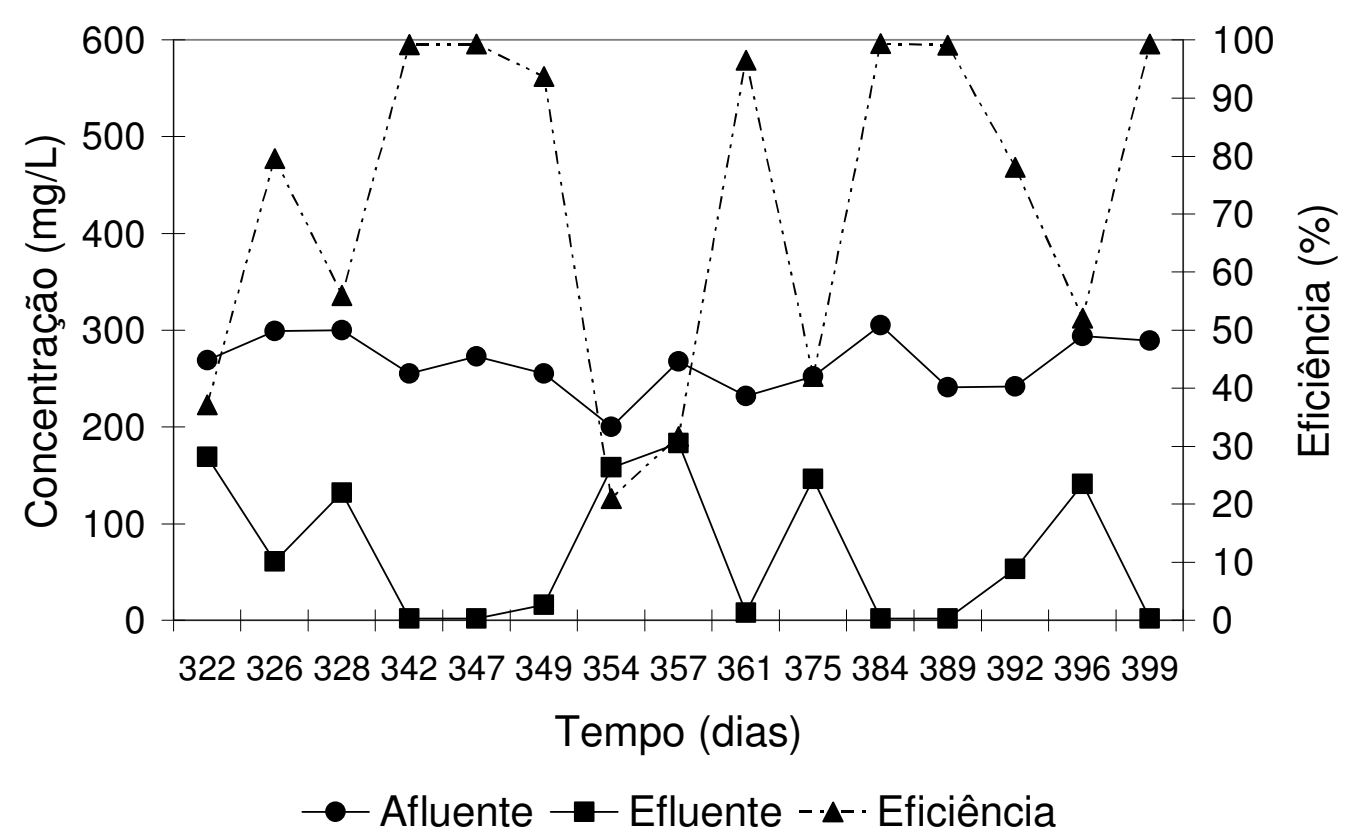

Figura 5.48: Variações das concentrações de fenol, no afluente e efluente do reator com manta de polipropileno $\left(\mathrm{R}_{1}\right)$, no TDH de $6 \mathrm{~h}$.

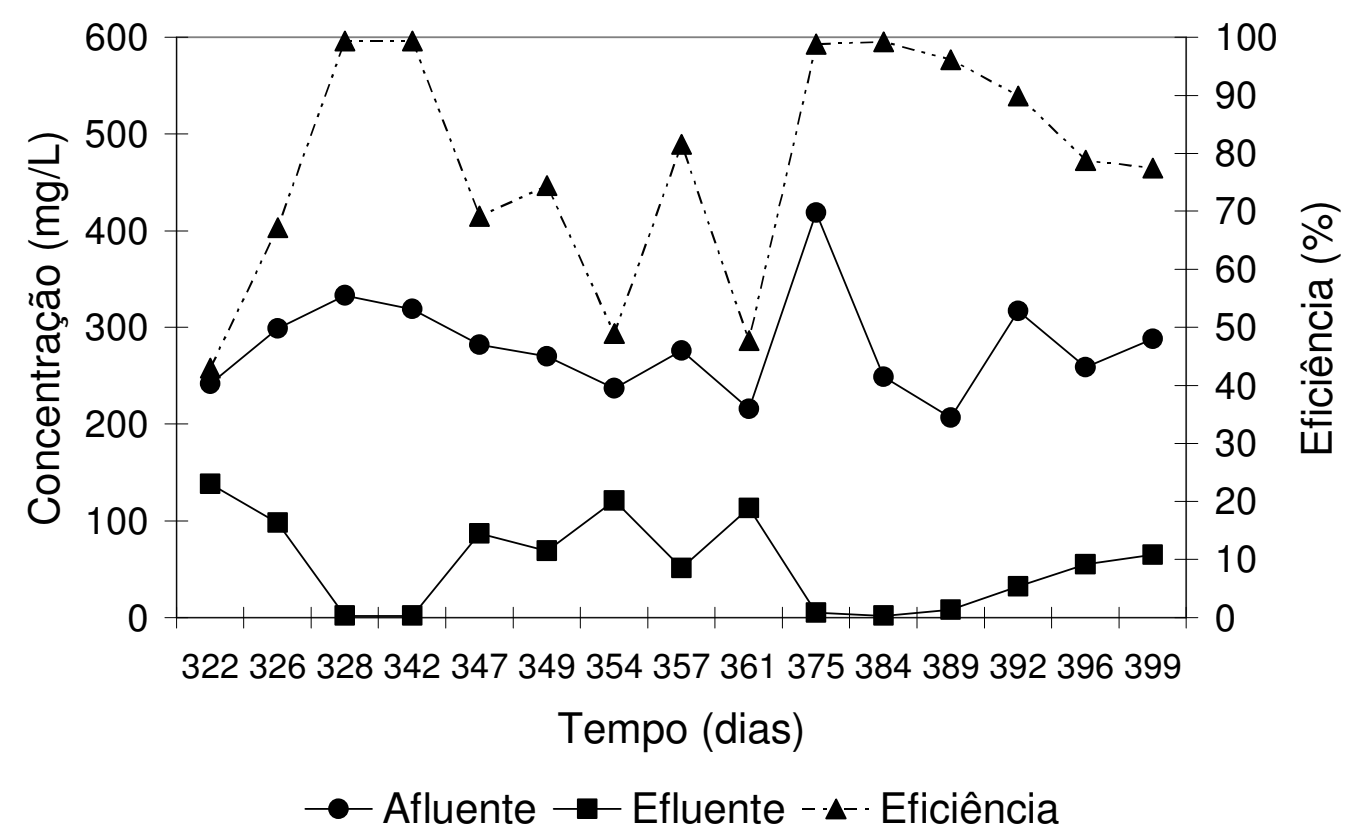

Figura 5.49: Variações das concentrações de fenol, no afluente e efluente do reator com espuma de poliuretano $\left(\mathrm{R}_{2}\right)$, no TDH de $6 \mathrm{~h}$.

Portanto, a remoção média de matéria orgânica (particulada e solúvel) e de fenol foi maior no tempo de detenção hidráulica mais longo, ou seja, no de $8 \mathrm{~h}$, que forneceu o tempo de contato adequado para os microrganismos utilizarem o substrato e, por este 
motivo, a eficiência diminuiu com a redução do TDH, conforme mostrado nas Figuras 5.50 e 5.51 .

Nas Figuras 5.52 e 5.53 são mostradas as variações do pH no afluente e efluente dos reatores com meio suporte de manta de polipropileno $\left(\mathrm{R}_{1}\right)$ e espuma de poliuretano $\left(\mathrm{R}_{2}\right)$. No reator $\mathrm{R}_{1}$, o pH do efluente apresentou valores entre 5,0 e 6,9 e em $\mathrm{R}_{2}$, entre 5,0 e 7,1. Houve diminuição muito sutil nos valores do pH em relação ao tempo de detenção hidráulica de $4 \mathrm{~h}$, particularmente no efluente do reator $\mathrm{R}_{2}$, porém não se pode inferir quanto à influência da concentração de ácidos graxos voláteis, pois não foram realizadas análises de $\mathrm{AGV}$ neste período de operação.

As variações das concentrações de oxigênio dissolvido são mostradas nas Figuras 5.54 e 5.55 .

Segundo Xiao et al. (2004), o aumento da quantidade de micélio e da produção de metabólitos, como polissacarídeos extracelulares, o que foi refletido nesta pesquisa pela colmatação dos meios suportes, contribuíram para elevar a viscosidade do líquido e a diminuir o nível de oxigênio no meio. De fato isto ocorreu em ambos os reatores, pois a concentração média de oxigênio dissolvido nos efluentes dos reatores foi a menor em relação às registradas nos tempos de detenção hidráulica de 4 h e 8 h, sendo obtidas concentrações médias de oxigênio dissolvido de $4 \mathrm{mg} / \mathrm{L} \pm 2$ e 4,5 mg/L \pm 2 .

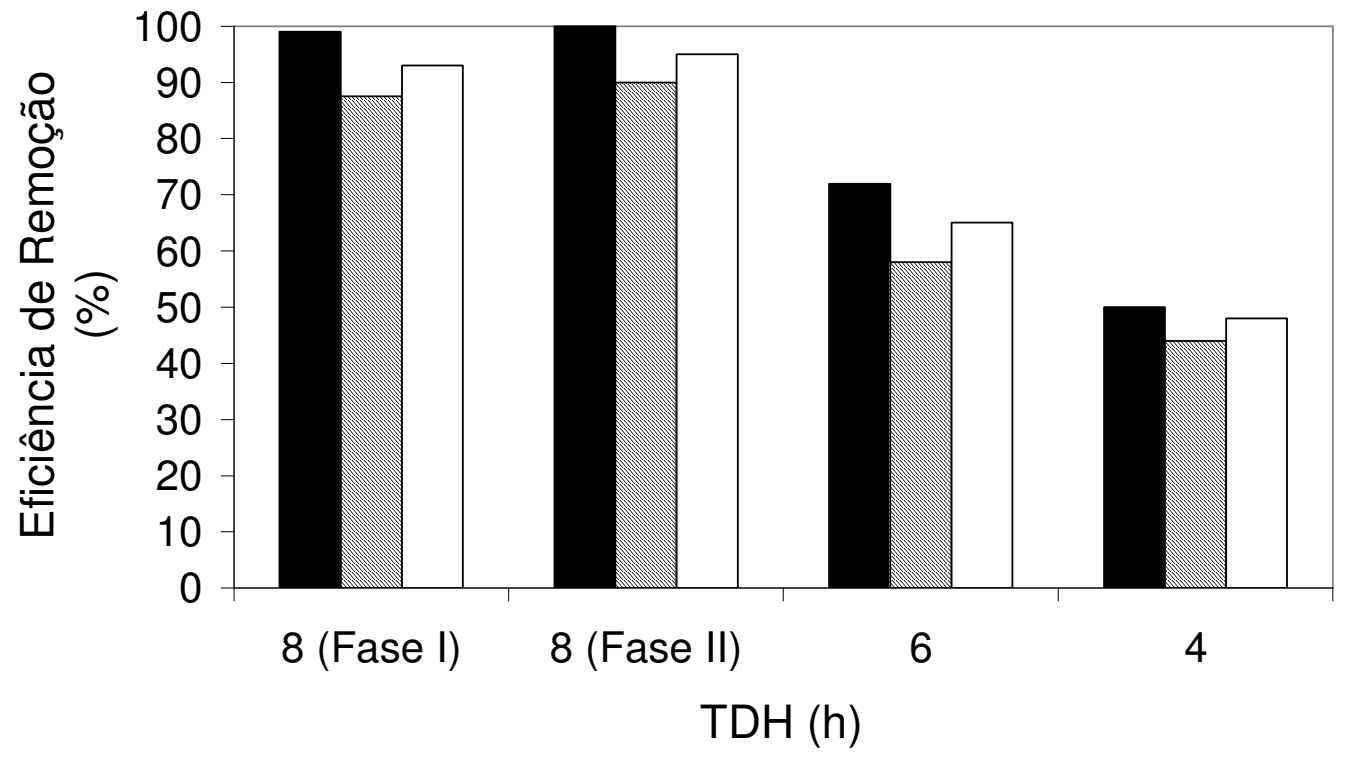

- Fenol $\mathbb{0}$ DQOtotal $\square$ DQOsolúvel

Figura 5.50: Variações das eficiências de remoção de matéria orgânica, medida em $\mathrm{DQO}$, e de fenol, no reator $\mathrm{R}_{1}$, durante o experimento de escoamento contínuo. 


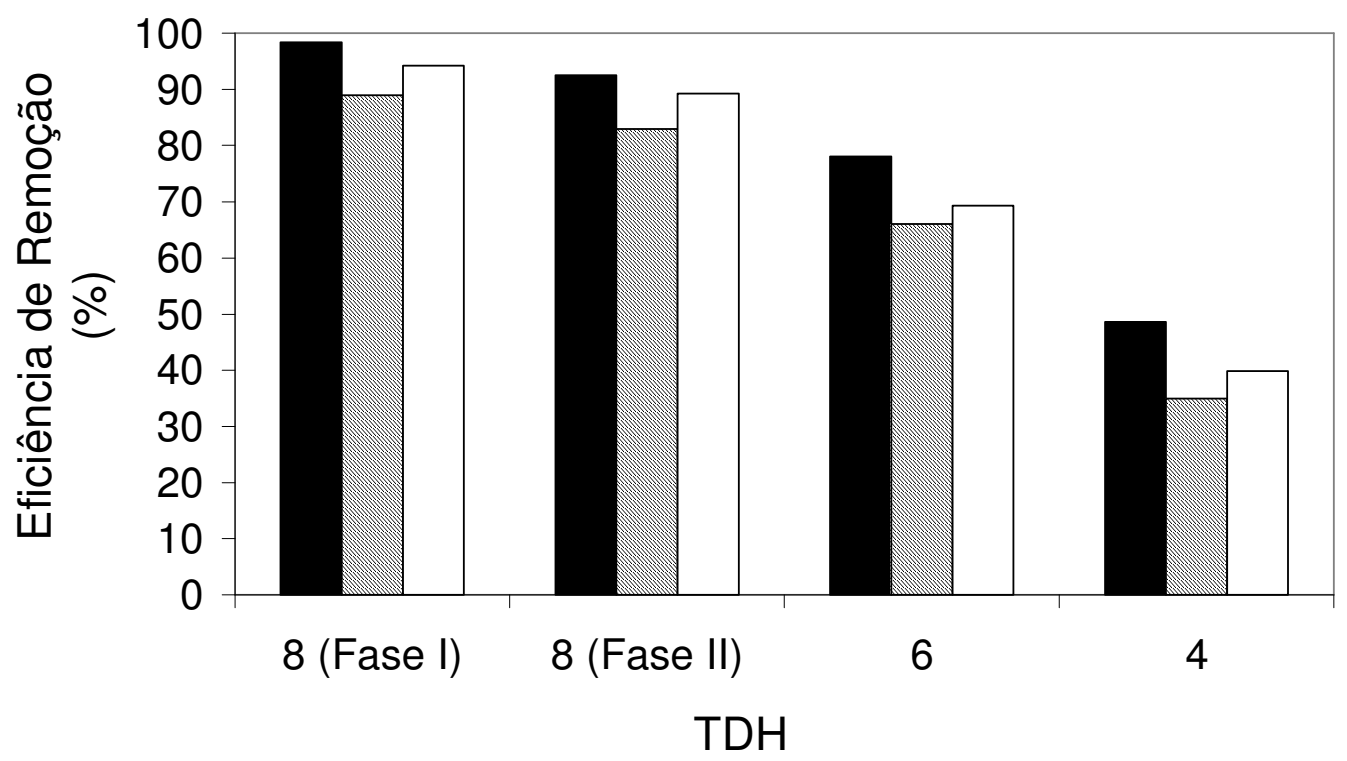

- Fenol $\square$ DQOtotal $\square$ DQOsolúvel

Figura 5.51: Variações das eficiências de remoção de matéria orgânica, medida em $\mathrm{DQO}$, e de fenol, no reator $\mathrm{R}_{2}$, durante o experimento de escoamento contínuo.

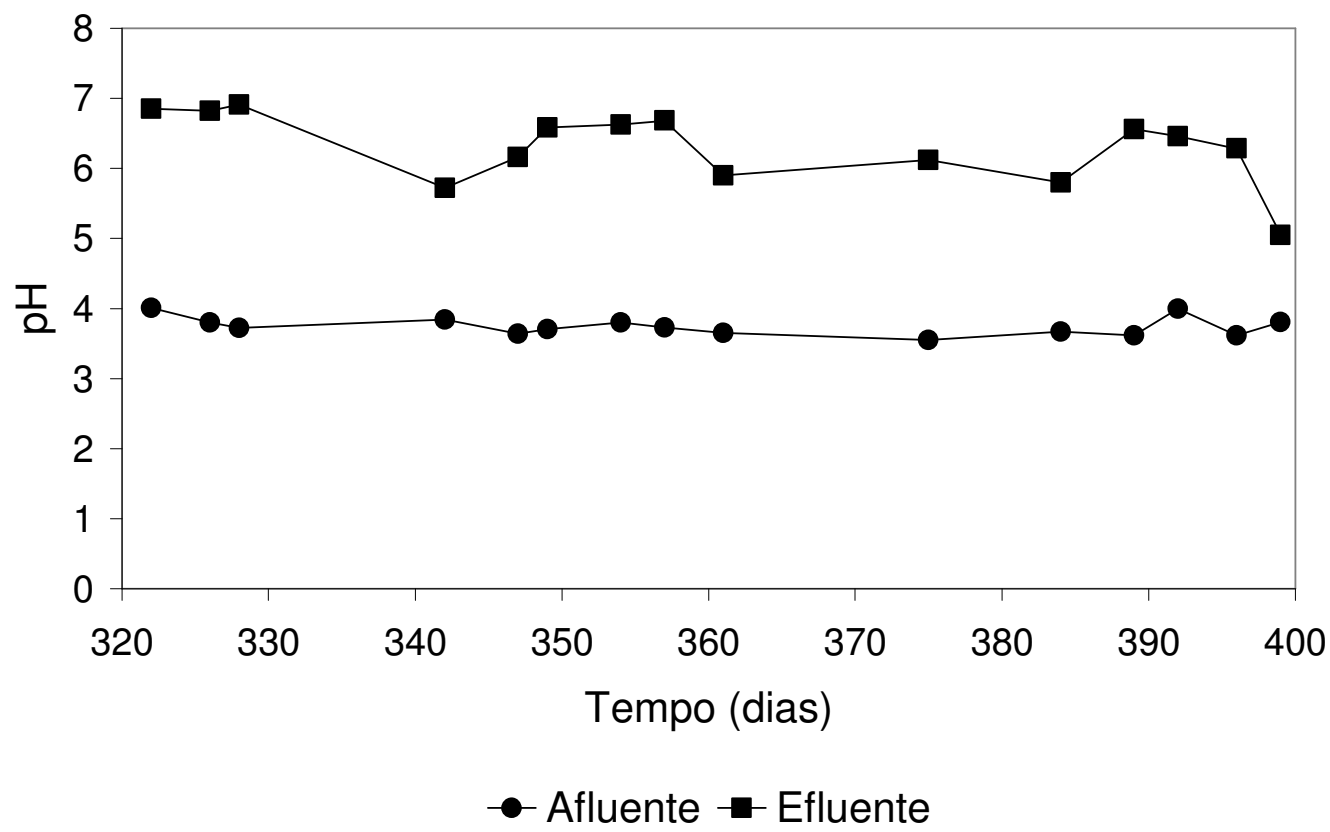

Figura 5.52: Variações do $\mathrm{pH}$ no afluente e efluente dos reatores com meio suporte de manta de polipropileno $\left(\mathrm{R}_{1}\right)$, no TDH de $6 \mathrm{~h}$. 


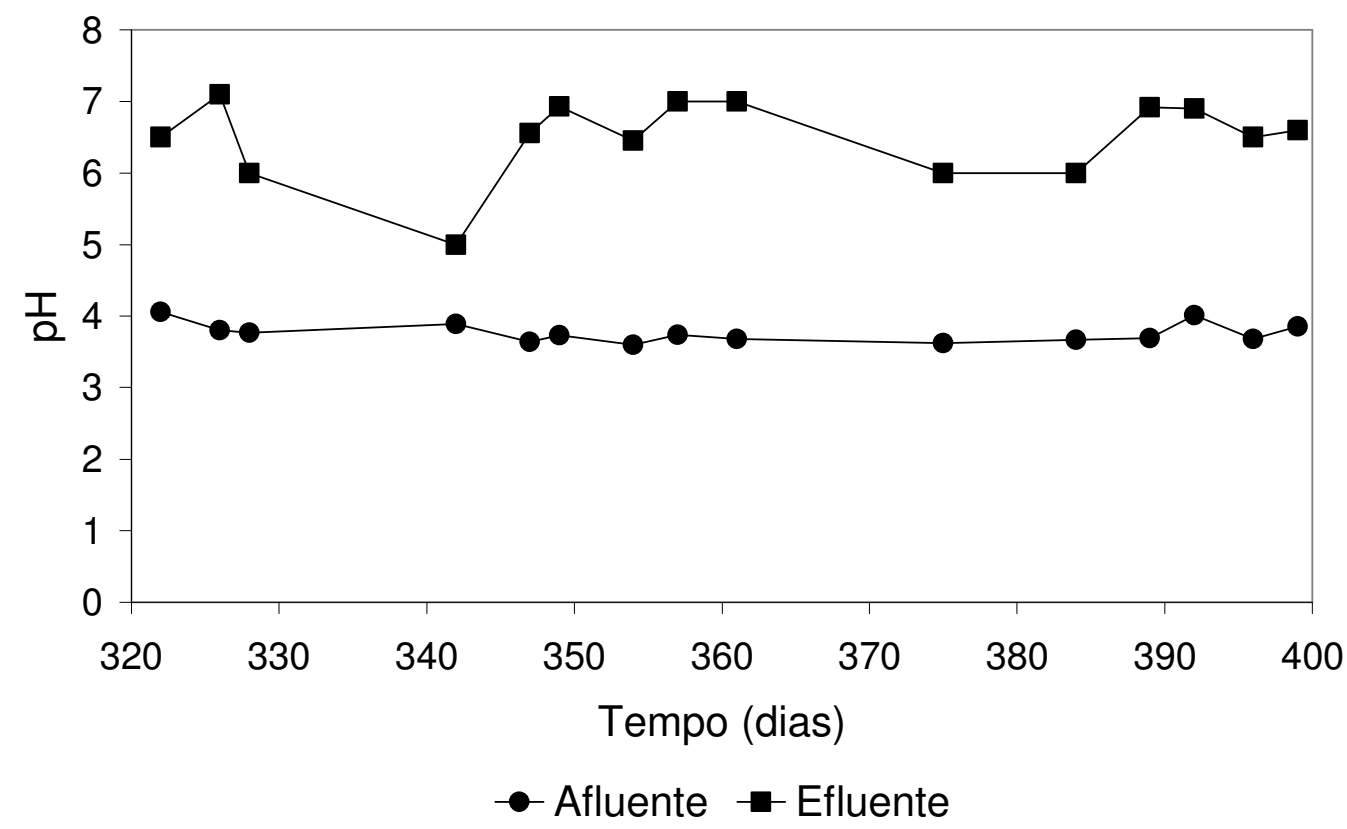

Figura 5.53: Variações do $\mathrm{pH}$ no afluente e efluente do reator com meio suporte de espuma de poliuretano $\left(\mathrm{R}_{2}\right)$, no TDH de $6 \mathrm{~h}$.

Como a vazão resultante do TDH de $6 \mathrm{~h}$ diminuiu, houve menor desprendimento do biofilme, o que aliado à ausência de concentração de glicose na água residuária, para controlar o crescimento do biofilme, favoreceu a colmatação dos meios suportes pela biomassa gerada, levando a freqüentes intervenções na tentativa de desobstruí-los, principalmente no reator $\mathrm{R}_{2}$, que recebeu espuma de poliuretano. $\mathrm{O}$ aumento da espessura do biofilme foi refletindo na grande variação da concentração de oxigênio dissolvido no meio, em ambos os reatores, com concentrações de OD variando de 1 a $7 \mathrm{mg} / \mathrm{L}$, no efluente do reator $\mathrm{R}_{1}$, e de 3 a $6 \mathrm{mg} / \mathrm{L}$, no efluente do reator $\mathrm{R}_{2}$.

Embora a eficiência de tratamento da água residuária neste tempo de detenção hidráulica tenha sido inferior à alcançada quando da operação dos reatores no TDH de $8 \mathrm{~h}$, questiona-se se maiores percentuais de remoção de matéria orgânica e fenol não poderiam ter sido alcançados com $6 \mathrm{~h}$ de detenção hidráulica, caso crescimento exagerado do biofilme fosse controlado.

A oscilação da concentração de oxigênio dissolvido devido ao crescimento exagerado do biofilme, segundo Lai et al. (2005), também resulta em problemas na morfologia da célula, provocando alterações das características bioquímicas e biológicas. Estas alterações metabólicas e a má agitação do meio contribuem para perda 
da capacidade dos microrganismos utilizarem eficientemente o substrato no seu metabolismo.

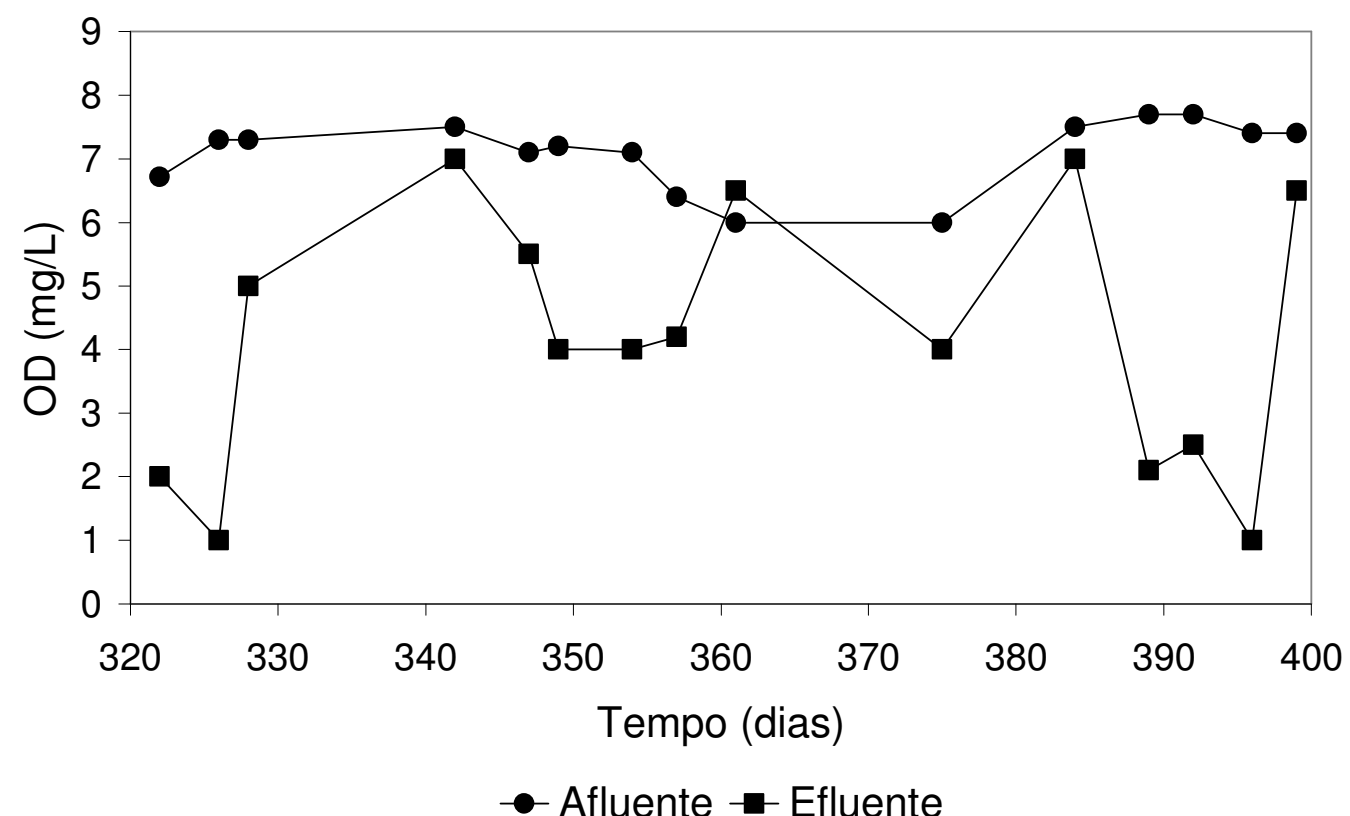

Figura 5.54: Variações das concentrações de OD, no afluente e efluente do reator com manta de polipropileno $\left(\mathrm{R}_{1}\right)$, no TDH de $6 \mathrm{~h}$.

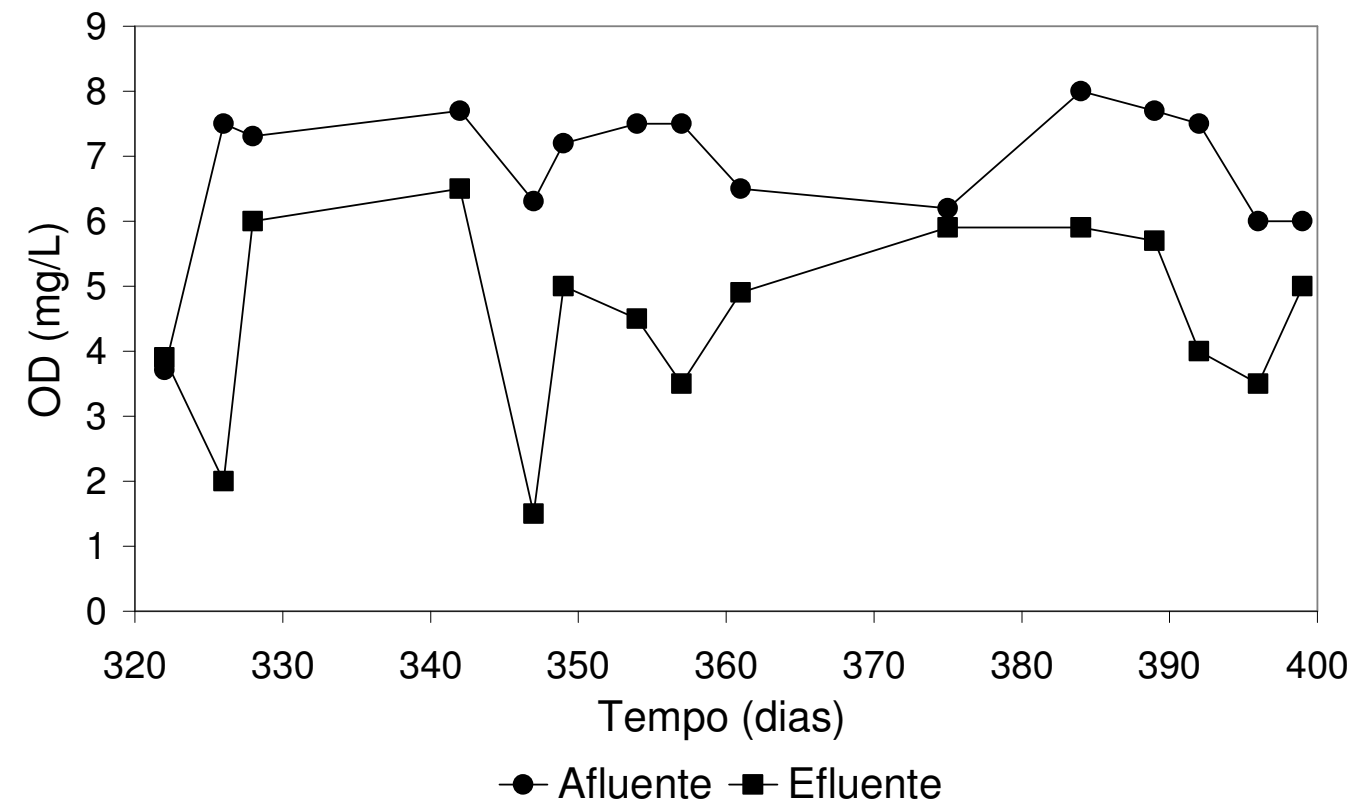

Figura 5.55: Variações das concentrações de OD, no afluente e efluente do reator com espuma de poliuretano $\left(\mathrm{R}_{2}\right)$, no TDH de $6 \mathrm{~h}$. 
Além disso, com a aeração inadequada, observou-se ainda a falta de homogeneidade na agitação do meio, dificultando a distribuição do substrato para as camadas mais internas do biofilme, pois, de acordo com Sankpal e Kulkarni (2002), a agitação homogênea é necessária para evitar a perda na eficiência de tratamento, o que é conseguido com a manutenção da concentração de oxigênio dissolvido ao longo da operação do reator com fungos.

A elevada produção de biomassa no interior foi confirmada no final do experimento, ao comparar os valores de STV obtidos em amostras do biofilme aderido aos meios suportes com valores de biomassa encontrados por outros pesquisadores.

Nesta pesquisa, enquanto foram determinados, respectivamente, 4,0 g STV/g de meio suporte e 5,0 g STV/g de meio suporte, para os reatores com meio suporte de manta de polipropileno $\left(\mathrm{R}_{1}\right)$ e espuma de poliuretano $\left(\mathrm{R}_{2}\right)$, Kim e Shoda (1999) relataram a obtenção de $3 \mathrm{~g}$ de biomassa/g de espuma de poliuretano, em experimento batelada para remoção de cor de melaço por Geotrichum candidum.

Em outro trabalho, Sankpal e Kulkarni (2002), ao utilizarem Aspergillus niger imobilizado em microfibras de celulose para produção de ácido glucônico, encontraram, no final do experimento, 2,4 $\mathrm{g}$ de biomassa/g de meio suporte, mostrando que, na presente pesquisa, houve produção acentuada de biomassa no interior dos reatores.

De acordo com Imai et al. (1995), meios com disponibilidade alta de nitrogênio, como no caso da água residuária sintética utilizada, favorecem o crescimento filamentoso dos fungos, ocorrendo a projeção das hifas para fora da superfície do meio suporte, bem como a ramificação acentuada de suas extremidades e o aumento da espessura da parede celular (PAPAGIANNI, 2004), facilitando a colmatação do leito de reatores, como observado nesta pesquisa, principalmente em relação ao reator $R_{2}$.

Como os cubos de poliuretano encontravam-se mais próximos uns dos outros, o crescimento desordenado dos fungos teria causado maior entrelaçamento das hifas, resultando, desta forma, nas obstruções mais freqüentes observadas no reator $\mathrm{R}_{2}$.

$\mathrm{O}$ reator com meio suporte de manta de polipropileno $\left(\mathrm{R}_{1}\right)$ apresentou eficiência de remoção de fenol e matéria orgânica ligeiramente superior ao de espuma de poliuretano $\left(\mathrm{R}_{2}\right)$, na maior parte do experimento. 
Assim, considerando apenas as eficiências de remoção de fenol e de matéria orgânica e o fato do reator $\mathrm{R}_{1}$ tê-las alcançado ao operar com menores intervenções, a manta de polipropileno foi o meio suporte mais adequado.

\subsubsection{Considerações sobre a remoção do fenol}

Apesar dos problemas relacionados ao crescimento excessivo do biofilme, observou-se a capacidade dos fungos de utilizarem o fenol como fonte de carbono para suas atividades metabólicas, constatada, ainda, pela presença de manchas escuras (Figura 5.56), atribuídas à síntese de melanina pelo Aspergillus niger, embora a determinação de análise para identificação da substância não tenha sido possível.
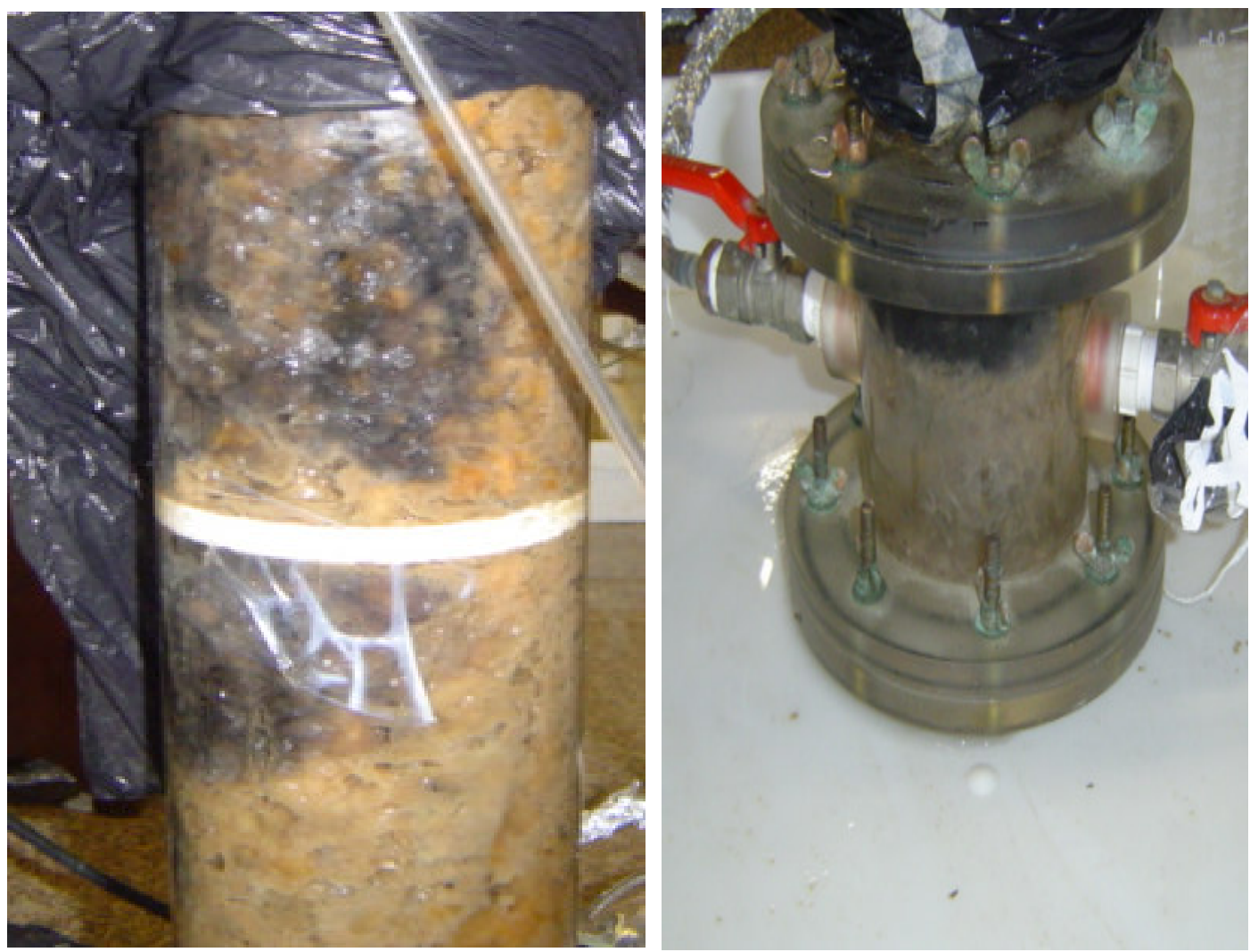

Figura 5.56: Manchas escuras nos reatores com fungos, no final do experimento de escoamento contínuo. 
A relação entre a síntese de melanina e a assimilação de hidrocarbonetos aromáticos pelos fungos produtores de melanina, é mencionada por Prenafeta Boldú (2002). O autor afirma que poucos fungos conseguem utilizar hidrocarbonetos monoaromáticos e, dentre esses, destacam-se as espécies produtoras de melanina, caracterizadas pela pigmentação escura da hifa, como o Aspergillus niger e outras espécies fúngicas patogênicas ao homem, sendo responsável pelo aumento do potencial de virulência do microrganismo.

A ligação entre a produção de melanina e a assimilação de fenol é reforçada por Costa et al. (2004). Os autores observaram que Fonsecaea pedrosoi, fungo causador de doenças de pele em humanos, na presença de um composto inibidor de seu crescimento (tricyclazole), não conseguiu produzir melanina, tendo-se o tricyclazole inibido a utilização de compostos fenólicos, percussores da síntese de melanina, os quais se acumularam no meio.

Desta forma, na presente pesquisa, a produção de melanina, caracterizada pelo escurecimento do biofilme, mostrou que o fenol foi removido pelo Aspergillus niger, pois o fungo teria utilizado o composto para produção de melanina.

A formação de melanina envolve a oxidação dos compostos fenólicos pelo oxigênio molecular, sendo lentamente oxidados, a partir da atuação das enzimas fenol oxidases (LANGFELDER et al., 2003), estimuladas pela presença de compostos como catecolamina, catecol, tirosina e $\gamma$-glutaminil-hidroxibenzeno (GHB) (CONCEIÇÃO et al., 2004).

De acordo com Conceição et al. (2004), estas enzimas estão associadas não apenas à síntese de melanina, mas também de outros pigmentos, catalisando oxidação do composto aromático e reduzindo-o a água. A via mais comum de produção da melanina é a condensação de resíduos de acetato para a formação de compostos polimerizados, resultando na melanina.

A melanina é um pigmento altamente insolúvel, geralmente, preto ou marrom, podendo se apresentar nas cores: vermelho, amarelo púrpura, verde e azul, o que depende do substrato a partir do qual é formada (ROSAS, et al., 2000), aderindo-se à parede celular e conferindo ao fungo resistência a ambientes adversos à sua sobrevivência (BUTLER et al., 2005). 
Em condições de elevado stress ambiental, a melanina, ao revestir a parede celular, ajuda o microrganismo a sobreviver, pois a célula melanizada fica mais rígida, ocorrendo o aumento da espessura da parede celular, o que evita o processo de lise (FORGATY e TOBIN, 1996; LANGFELDER et al., 2003).

Esta proteção celular explicou o porquê dos reatores não terem apresentado coloração mais escura desde o início de sua operação, pois, após longo período de exposição ao fenol, os fungos passaram a produzir melanina como forma de evitar a ruptura da célula, garantindo, assim, sua sobrevivência.

\subsubsection{Ensaio de Adsorção nos Meios Suportes}

Antes da partida dos reatores de leito fixo foram realizados ensaios para determinar a capacidade de adsorção dos meios suportes (manta de polipropileno e espuma de poliuretano), de acordo com os procedimentos descritos por Bolaños et al. (2001).

Os dados obtidos durante o ensaio de adsorção no reator com meio suporte de manta de polipropileno (reator $\mathrm{R}_{1}$ ) são mostrados na Tabela 5.4, sendo a vazão resultante do TDH $(2 \mathrm{~h})$ empregado de 1,20 L/h e a concentração inicial de fenol de $700 \mathrm{mg} / \mathrm{L}$.

Tabela 5.4: Dados de adsorção de fenol no meio suporte de manta de polipropileno $\left(\mathrm{R}_{1}\right)$.

\begin{tabular}{cccc}
\hline $\begin{array}{c}\text { Tempo } \\
(\mathbf{h})\end{array}$ & $\begin{array}{c}\mathbf{C}_{\mathbf{e}} \\
(\mathbf{m g} / \mathbf{L})\end{array}$ & $\begin{array}{c}\left(\mathbf{C}_{\mathbf{0}}-\mathbf{C}_{\mathbf{e}}\right) \\
(\mathbf{m g} / \mathbf{L})\end{array}$ & $\begin{array}{c}\text { Q. }\left(\mathbf{C}_{\mathbf{0}}-\mathbf{C}_{\mathbf{e}}\right)^{*} \Delta \mathbf{t} \\
(\mathbf{m g})\end{array}$ \\
\hline 0 & 0 & 0 & 0 \\
0,17 & 577 & 123 & 26 \\
0,33 & 400 & 300 & 122 \\
0,50 & 557 & 143 & 88 \\
0,67 & 623 & 77 & 63 \\
0,83 & 698 & 2 & 2 \\
1,0 & 705 & 0 & 0 \\
\hline $\boldsymbol{\Sigma}$ & 700 & 0 & 0 \\
\hline
\end{tabular}


$\mathrm{C}_{\mathrm{o}}$ : Concentração de fenol na entrada do reator $(\mathrm{mg} / \mathrm{L})$;

$\mathrm{C}_{\mathrm{e}}$ : Concentração de fenol na saída do reator no tempo (mg/L);

Q: Vazão (L/h);

$\Delta \mathrm{t}$ : Variação de tempo (h).

A massa de fenol de $301 \mathrm{mg}$, adsorvida em $135 \mathrm{~g}$ de manta de polipropileno, revela que em cada grama do meio suporte foram adsorvidos $0,002 \mathrm{~g}$ de fenol.

Para o cálculo da massa de fenol removida durante os 399 dias de operação do reator $\mathrm{R}_{1}$ foram utilizados os dados de concentração de fenol na entrada e saída do reator, do volume útil do reator de $2,4 \mathrm{~L}$ e das vazões de 7,2 L/dia, $14,4 \mathrm{~L} /$ dias e 9,6 L/dias, relativas aos tempos de detenção hidráulica de 8 h, 4 h e 6 h, respectivamente. A massa de fenol removida em cada tempo de detenção hidráulica é apresentada na Tabela 5.5.

Tabela 5.5: Massas de fenol removidas durante a operação do reator com meio suporte de manta de polipropileno $\left(\mathrm{R}_{1}\right)$

\begin{tabular}{|c|c|c|}
\hline $\begin{array}{c}\text { TDH } \\
\text { (h) }\end{array}$ & $\begin{array}{c}\text { Operação } \\
\text { (dias) }\end{array}$ & $\begin{array}{l}\text { Massa de fenol } \\
\text { removida }(\mathrm{mg})\end{array}$ \\
\hline 8 & 146 & 250442 \\
\hline 4 & 159 & 252497 \\
\hline 6 & 94 & 164832 \\
\hline \multicolumn{2}{|c|}{$\Sigma$} & 667770 \\
\hline
\end{tabular}

Como foram removidos, aproximadamente, $668 \mathrm{~g}$ de fenol durante a operação do reator $\mathrm{R}_{1}$, tem-se para $1 \mathrm{~g}$ de manta de polipropileno $5 \mathrm{~g}$ de fenol. Portanto, a massa de fenol removida foi maior que a adsorvida, obtida quando do ensaio de adsorção no meio suporte.

Na Tabela 5.6 são apresentados os dados relativos ao ensaio de adsorção no meio suporte de espuma de poliuretano $\left(\mathrm{R}_{2}\right)$. A vazão resultante do tempo de detenção hidráulica de $2 \mathrm{~h}$ foi de $1,2 \mathrm{~L} / \mathrm{h}$ e a concentração inicial de fenol, de $574 \mathrm{mg} / \mathrm{L}$. 
Para a massa de fenol total adsorvida na espuma de poliuretano de $8837 \mathrm{mg}$ em 63,5 g de espuma de poliuretano, tem-se que em cada grama do meio suporte foi adsorvido $0,14 \mathrm{~g}$ de fenol.

Para o cálculo da massa de fenol removida durante os 399 dias de operação do reator $\mathrm{R}_{2}$ foram utilizados os dados de concentração de fenol na entrada e saída do reator, do volume útil do reator de $2,4 \mathrm{~L}$ e das vazões de $7,2 \mathrm{~L} / \mathrm{dia}, 14,4 \mathrm{~L} /$ dias e 9,6 L/dias, relativas aos tempos de detenção de $8 \mathrm{~h}, 4 \mathrm{~h}$ e $6 \mathrm{~h}$, respectivamente. A massa de fenol removida em cada tempo de detenção é mostrada na Tabela 5.7.

Tabela 5.6: Dados de adsorção de fenol no meio suporte de espuma de poliuretano $\left(\mathrm{R}_{2}\right)$.

\begin{tabular}{cccc}
\hline $\begin{array}{c}\text { Tempo } \\
(\mathbf{h})\end{array}$ & $\begin{array}{c}\mathbf{C}_{\mathbf{e}} \\
(\mathbf{m g} / \mathbf{L})\end{array}$ & $\begin{array}{c}\left(\mathbf{C}_{\mathbf{0}}-\mathbf{C}_{\mathbf{e}}\right) \\
(\mathbf{m g} / \mathbf{L})\end{array}$ & $\begin{array}{c}\text { Q. }\left(\mathbf{C}_{\mathbf{0}}-\mathbf{C}_{\mathbf{e}}\right)^{*} \Delta \mathbf{t} \\
(\mathbf{m g})\end{array}$ \\
\hline 0 & 0 & 0 & 0 \\
2 & 301 & 273 & 655 \\
4 & 363 & 211 & 1013 \\
6 & 376 & 198 & 1426 \\
8 & 391 & 183 & 1757 \\
10 & 450 & 124 & 1488 \\
& 431 & 143 & 2059 \\
& 12 & 11 & 185 \\
& 563 & 4 & 77 \\
16 & 560 & 6 & 130 \\
\hline $\mathbf{\Sigma}$ & 568 & 2 & 48 \\
\hline & 572 & & 8837 \\
\hline
\end{tabular}

$\mathrm{C}_{\mathrm{o}}$ : Concentração de fenol na entrada do reator $(\mathrm{mg} / \mathrm{L})$;

$\mathrm{C}_{\mathrm{e}}$ : Concentração de fenol na saída do reator no tempo (mg/L);

Q: Vazão (L/h);

$\Delta \mathrm{t}$ : Variação de tempo (h). 
Tabela 5.7: Massas de fenol removidas durante a operação do reator com meio suporte de espuma de poliuretano $\left(\mathrm{R}_{2}\right)$

\begin{tabular}{|c|c|c|}
\hline $\begin{array}{c}\text { TDH } \\
\text { (h) }\end{array}$ & $\begin{array}{c}\text { Operação } \\
\text { (dias) }\end{array}$ & $\begin{array}{l}\text { Massa de fenol } \\
\text { removida }(\mathrm{mg})\end{array}$ \\
\hline 8 & 146 & 278933 \\
\hline 4 & 159 & 285918 \\
\hline 6 & 94 & 211872 \\
\hline \multicolumn{2}{|c|}{$\Sigma$} & 776723 \\
\hline
\end{tabular}

Como foram removidos, aproximadamente, $777 \mathrm{~g}$ de fenol durante a operação do reator $\mathrm{R}_{2}$, tem-se para $1 \mathrm{~g}$ de meio suporte $12 \mathrm{~g}$ de fenol. Portanto, a massa de fenol removida (777 g) foi maior que a massa adsorvida $(8,5 \mathrm{~g})$, obtida quando do ensaio de adsorção no meio suporte.

O ensaio de adsorção nos materiais empregados como suporte dos reatores de leito fixo mostrou que a manta de polipropileno apresenta menor potencial de adsorção que a espuma de poliuretano, uma vez que este último tem capacidade de adsorver 70 vezes mais fenol em relação à manta de polipropileno. 


\subsubsection{Exames Microscópicos}

Nas Figuras 5.57 e 5.58 são apresentados os microrganismos observados nos reatores com suporte de manta de polipropileno $\left(\mathrm{R}_{1}\right)$ e de espuma de poliuretano $\left(\mathrm{R}_{2}\right)$.

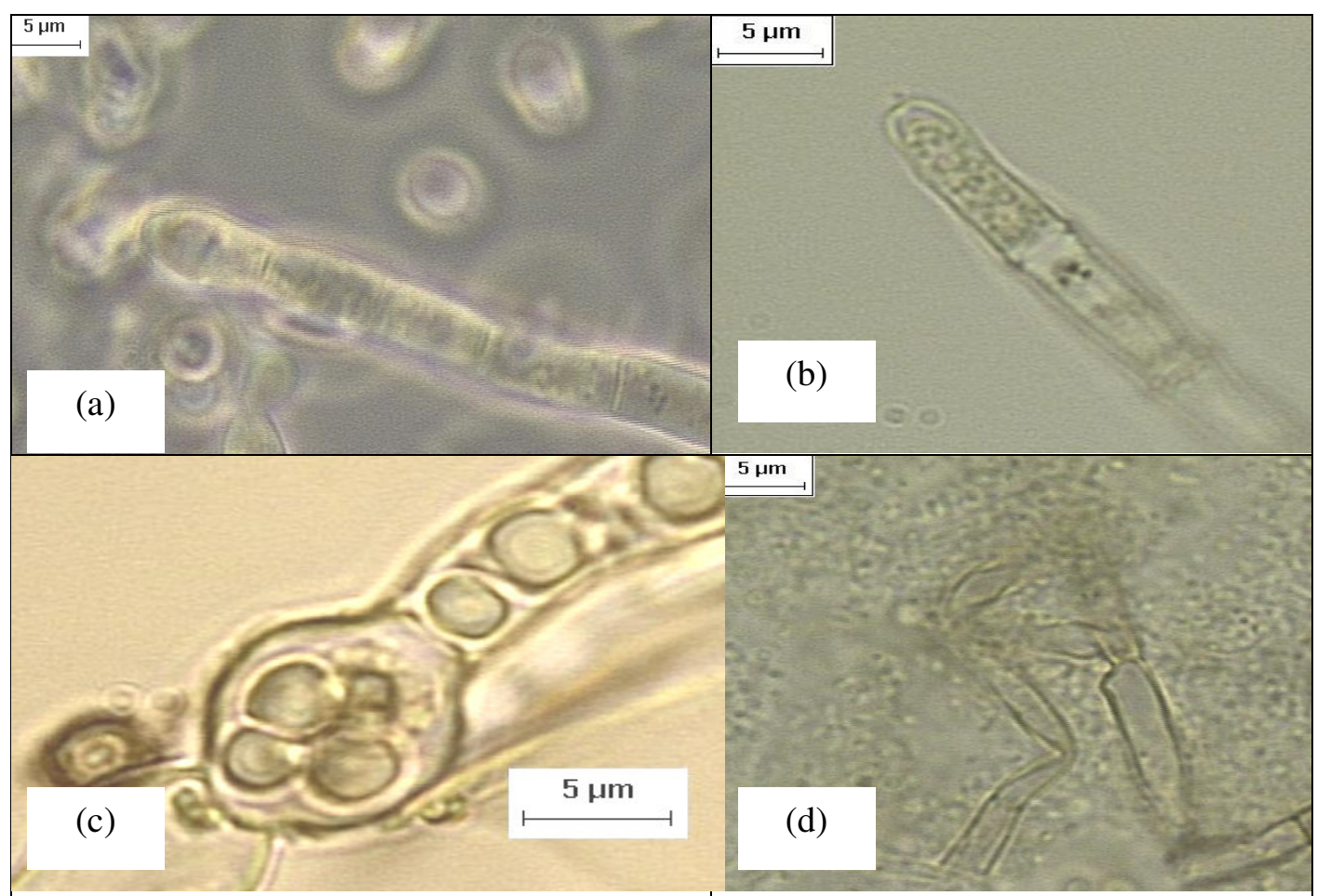

Figura 5.57: Microrganismos desprendidos da manta de polipropileno: (a) Aspergillus niger e leveduras; (b) Hifa de Aspergillus niger; (c) Alargamento da hifa; (d) Material gelatinoso envolvendo o micélio.

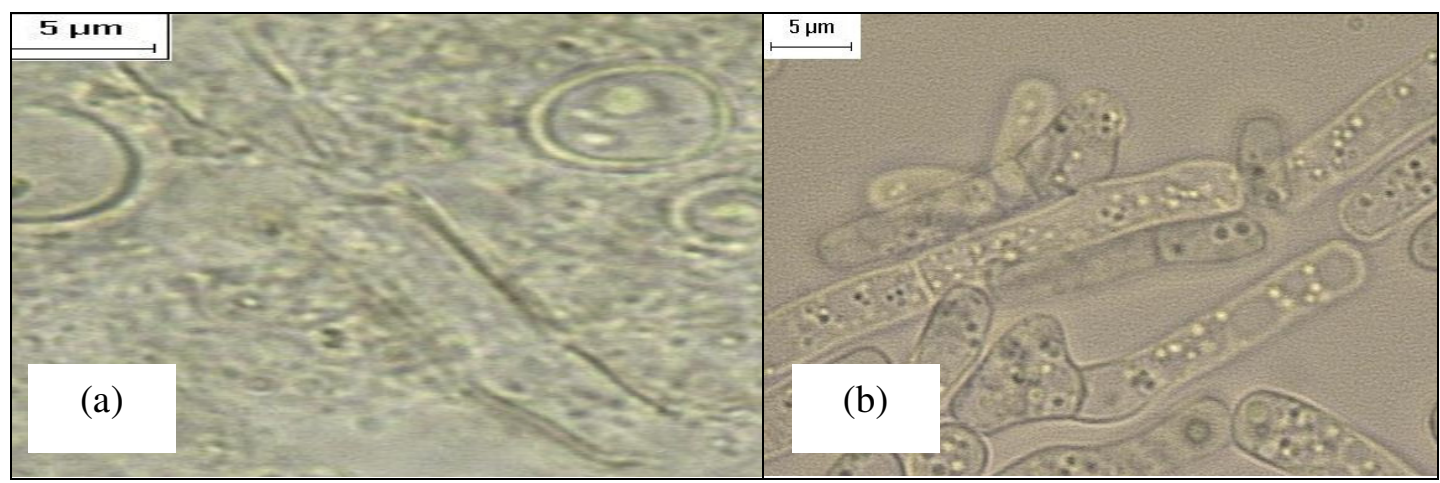

Figura 5.58: Microrganismos desprendidos da espuma de poliuretano: (a) Hifa submersa em material gelatinoso; (b) Fragmento de hifas de Aspergillus niger e leveduras. 
O exame microscópico mostrou a existência de leveduras e de Aspergillus niger, espécie predominante no reator. Também foi constatada a presença de bactérias, as quais não puderam ser identificadas, porém em quantidade pouco significativa.

Particularmente, em relação às leveduras, foram observados relatos do sucesso do seu emprego em reatores biológicos para remoção de fenol (JUAREZ-RAMIREZ et al., 2001; BERGAUER et al., 2005) e tolueno (WOERTZ et al., 2001).

Tanto leveduras como fungos do gênero Aspergillus têm sido isolados e identificados em meios contendo fenol. Ciafardini e Zullo (2002) verificaram a ausência de bactérias a existência de leveduras e de Aspergillus sp. no azeite de oliva virgem, em processo de decantação, meio que apresenta compostos fenólicos e caracteriza-se por alta atividade antimicrobiana, o que demonstra a capacidade das leveduras e do gênero Aspergillus de sobreviverem em meio com fenol.

Nesta pesquisa, ainda que Aspergillus niger seja a espécie dominante, a formação deste consórcio microbiano, foi benéfica ao sistema, em face da alta remoção de matéria orgânica e fenol, alcançada especialmente no tempo de detenção hidráulica de 8 h.

Grandes quantidades de material gelatinoso foram formadas nos reatores com meio suporte de manta de polipropileno $\left(\mathrm{R}_{1}\right)$ e espuma de poliuretano $\left(\mathrm{R}_{2}\right)$, conforme mostrado nas Figuras 5.57 (d) e 5.58 (a).

Nas Figuras 5.59 e 5.60 são apresentados detalhes dos biofilmes aderidos aos meios suportes de manta de polipropileno e espuma de poliuretano, respectivamente, nos reatores $\mathrm{R}_{1}$ e $\mathrm{R}_{2}$.

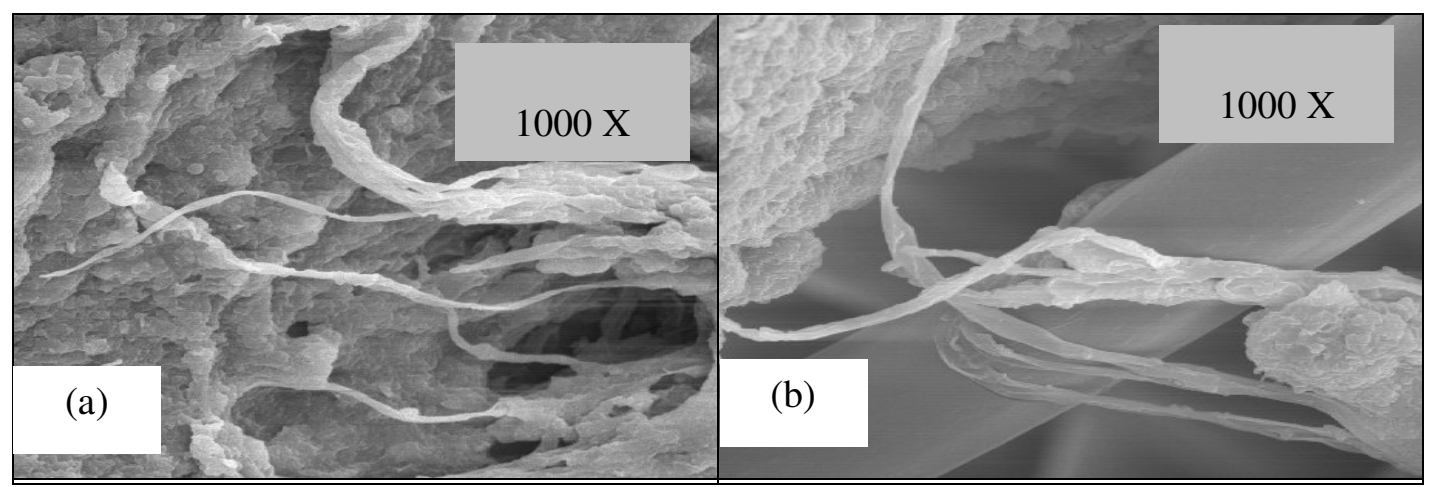

Figura 5.59: MEV (microscopia eletrônica de varredura) dos microrganismos aderidos ao meio suporte de manta de polipropileno (reator $\mathrm{R}_{1}$ ): (a) Hifas de Aspergillus niger; (b) Hifa de Aspergillus niger. 


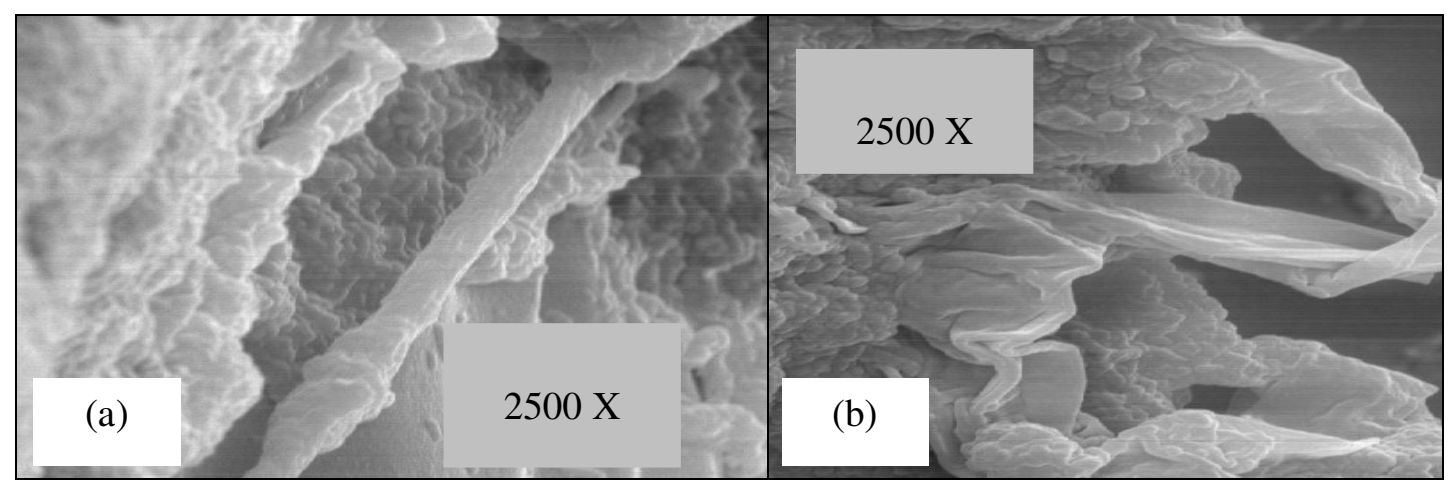

Figura 5.60: MEV (microscopia eletrônica de varredura) dos microrganismos aderidos ao meio suporte de espuma de poliuretano (reator $\mathrm{R}_{2}$ ): (a) Aspergillus niger; (b) Hifa de Aspergillus niger.

A partir da análise da microscopia de varredura, foi verificado que os microrganismos cresceram bem sobre a superfície da manta de polipropileno e da espuma de poliuretano, empregados como meio suporte. Foi também observada grande quantidade de material gelatinoso produzido, pelos microrganismos, envolvendo as estruturas dos fungos. 


\subsubsection{Comparação das eficiências médias de remoção de fenol nos TDH estudados em relação ao CONAMA (2005)}

Na Tabela 5.8 são mostradas as concentrações médias de fenol nos efluentes dos reatores com manta de polipropileno $\left(\mathrm{R}_{1}\right)$ e com espuma de poliuretano $\left(\mathrm{R}_{2}\right)$.

Tabela 5.8: Concentrações médias de fenol nos efluentes dos reatores com meio suporte de manta de polipropileno $\left(\mathrm{R}_{1}\right)$ e espuma de poliuretano $\left(\mathrm{R}_{2}\right)$

\begin{tabular}{|c|c|c|c|c|}
\hline & \multirow[b]{2}{*}{ TDH } & \multicolumn{2}{|c|}{$\begin{array}{c}\text { Concentração Média de } \\
\text { Fenol (mg/L) }\end{array}$} & \multirow{2}{*}{$\begin{array}{c}\text { Limite CONAMA } \\
\text { No. } 357 \text { (2005) } \\
\text { Fenóis Totais } \\
\text { (mg/L) }\end{array}$} \\
\hline & & $\mathbf{R}_{1}$ & $\mathbf{R}_{2}$ & \\
\hline \multirow{4}{*}{8} & Fase I & & & \\
\hline & (com glicose) & 1 & 4 & \\
\hline & Fase II & & & \\
\hline & (sem glicose) & 1 & 16 & 0,5 \\
\hline 4 & & 118 & 121 & \\
\hline 6 & & 72 & 57 & \\
\hline
\end{tabular}

As concentrações médias de fenol obtidas pelos reatores com fungos estão acima do exigido pela CONAMA $\mathrm{n}^{\mathrm{o}} 357$ (2005) para lançamento de efluentes, contudo verifica-se que, no tempo de detenção de $8 \mathrm{~h}$, os valores obtidos foram mais próximos do que é determinado no país, particularmente, no efluente do reator $\mathrm{R}_{1}$. Assim, para adequar o efluente dos reatores com fungos, em relação à concentração de fenol, exigida pela CONAMA $n^{\circ} 357$ (2005), há a necessidade de proceder a um pós-tratamento, ou ainda, verificar a operação do reator sob um tempo de detenção hidráulica maior. 


\section{CONCLUSÕES E RECOMENDAÇÕES}

\subsection{CONCLUSÕES}

Os resultados obtidos nesta pesquisa permitem concluir que:

- A principal via de remoção do fenol por Aspergillus niger foi a de assimilação, tendo a espécie utilizado o fenol como fonte de carbono e energia, removendo-o da água residuária sintética com altos percentuais de remoção;

- A glicose foi importante não apenas no início do crescimento dos fungos, para a adaptação dos microrganismos à água residuária com fenol e a formação inicial do biofilme, mas também para o controle da produção excessiva de biomassa;

- Na batelada, a presença de glicose permitiu maior crescimento dos fungos e conseqüentemente maior consumo de fenol, com velocidades média e máxima, respectivamente, de $0,18 \mathrm{~d}^{-1}$ e de $0,76 \mathrm{~d}^{-1}$. Na ausência da glicose, foram alcançadas velocidades média e máximas de apenas $0,094 \mathrm{~d}^{-1}$ e de $0,14 \mathrm{~d}^{-1}$;

- No experimento contínuo, o meio com elevada concentração de nitrogênio e limitação de carbono (sem glicose) favoreceu a produção excessiva de biomassa, enquanto que o meio com nitrogênio e carbono em proporções equivalentes (com glicose) permitiu menor crescimento de biomassa;

- As maiores remoções de fenol em relação à de matéria orgânica indicou a presença de compostos formados pela degradação do fenol e de substâncias excretadas no meio pelos microrganismos; 
- Nos reatores contínuos de leito fixo, o menor contato do biofilme com o substrato, nos menores tempos de detenção hidráulica resultou na diminuição da eficiência de remoção de matéria orgânica solúvel e de fenol, sendo o TDH mais eficiente na seguinte ordem: 8 h, 6 h e 4 h;

- A espuma de poliuretano possui maior capacidade de adsorção de fenol, 70 vezes mais que a manta de polipropileno;

- A remoção de fenol nos reatores contínuos foi superior à capacidade de adsorção dos meios suportes;

- Os fungos cresceram bem tanto na manta de polipropileno quanto na espuma de poliuretano;

- Aspergillus niger foi a espécie predominante nos reatores;

- Baseando-se apenas nas eficiências de remoção de fenol e matéria orgânica e na maior colmatação observada no reator com espuma de poliuretano, o melhor meio suporte foi a manta de polipropileno.

\subsection{RECOMENDAÇÕES}

A partir dos resultados e conclusões obtidas nesta pesquisa, recomenda-se:

- Estudar a influência da relação C/N sobre o crescimento de Aspergillus niger, utilizando a água residuária sintética com fenol, avaliando a produção de biomassa em diferentes meios suportes e remoção de matéria orgânica e fenol;

- Avaliar a influência da variação de oxigênio sobre a remoção de matéria orgânica e fenol por Aspergillus niger;

- Utilizar água residuária com compostos fenólicos de maior peso molecular e estudar seu tratamento por Aspergillus niger em reatores batelada e de escoamento contínuo, bem como testar o emprego de diferentes concentrações de glicose e de outros substratos primários sobre a eficiência do processo; 
- Estudar o metabolismo de Aspergillus niger em relação ao consumo de nitrogênio;

- Na água residuária sintética com fenol, utilizar unicamente o sulfato de amônio como fonte de nitrogênio, evitando a presença de nitrato, para tentar manter o $\mathrm{pH}$ com valores mais baixos, os quais são mais propícios ao desenvolvimento de Aspergillus niger e comparar com os dados obtidos nesta pesquisa;

○ Procurar obter melhores remoções de matéria orgânica e fenol em um reator com escoamento contínuo operado com o TDH 6 pelo controle do crescimento de biomassa dentro do reator utilizando uma água residuária nutricionalmente equilibrada.

○ Estudar, em termos de microbiologia, a formação e estabelecimento do biofilme com fungos em diversos meios suportes. 


\section{REFERÊNCIAS BIBLIOGRÁFICAS}

AINSWORTH, G. C., SUSSMAN, A. S. (1966). The fungi: an advanced treatise. Londor: Academic Press. v.1, 426p.

AL-MALAH, K.; AZZAM, M. O. J.; ABU-LAIL, N. (2000). Olive mills effluent (OME) wastewater post-treatment using activated clay. Separation and Purification Technology, 20:225-234.

AMBRÓSIO, S. T., CAMPOS-TAKAKI, G. M. (2004). Decolorization of reactive azo dyes by Cunninghamella elegans UCP 542 under co-metabolic conditions. Bioresource Technology. 91: $69-75$.

ANDER, P., MARZULLO, L. (1997). Sugar oxidoreductase and veratryl alcohol oxidase as related to lignindegradation. J. Biotechnol. 53:115-131.

APHA (1998). Standard methods for the examination of water and wastewater. $20^{\mathrm{a}}$. ed. Washington: American Public Health Association.

ARICA, M. Y., KAÇAR, Y., GENÇ, O. (2001). Entrapment of White-rot fungus Trametes versicolor in Ca-alginate beads: preparation and biosorption kinetic analysis for cadmium removal from na aqueous solution. Biresource Technology. 80: 121 - 129. 
ASSADI, M. M., JAHANGIRI, M. R. (2001). Textile wastewater treatment by Aspergillus niger. Desalination. 14: 1-6.

ASSAS, N., AYED, L., MAROUANI, L., HAMDI, M. (2002). Decolorization of fresh and stored-black olive Mill wastewaters by Geotrichum candidum. Process Biochemistry. 38: $361-365$.

BALAN, D. S. L., MONTEIRO, R. T. R. (2001). Decolorization of textile índigo dye by lignolytic fungi. Journal of Biotechnology. 89: 141 - 145.

BERGAUER, P., FONTEYNE, P., NOLARD, N., SCHINNER, F., MARGESIN, R. (2005). Biodegradation of phenol and phenol-related compounds by psychrophilic and cold-tolerant alpine yeasts. Chemosphere, v. 59, i. 7, may, p. $909-918$.

BESLE, J. M., JOUANY, J. P., CORNU, A. (1995). Transformation of structural phenylpropanoids during cell wall digestion. FEMS Microbiology Reviews. 16: 33 52.

BITTON, G. (1994). Wastewater microbiology. New York, 17-19p.

BLENKINSOPP, S. A., COSTERTON, J. W. (1991). Understand bacterial biofilms. Trends in Biotecnology, 9: $138-143$.

BOLAÑOS, M. L. R., VARESCHE, M. B. A., ZAIAT, M, FORESTI, E. (2001). Phenol degradation in horizontal-flow anaerobic immobilized biomass (haib) reactor under mesophilic conditions. Water Science and Technology. 44: 4: 167 - 174. 
BORJA, R., MARTIN, A., ALONSO, V., GARCÍA, I., BANKS, C. G. (1995). Influence of different aerobic pretreatments on the kinetics of anaerobic digestion of olive mill wastewater. Water Research. 29: 2: 489 - 495.

BUTLER, M. J., GARDINER, R. B., DAY, A. W. (2005). Degradation of melanin or ihibition of its synthesis: are these a significant approach as a biological control of phytopathogenic fungi? Biological Control. 32: 326 - 336.

CARLILE, M. J., WATKINSON, S. C. (1994). The Fungi. Academic Press - Harcourt Brace \& Company, San Diego.

CAZA, N., BEWTRA, J. K., BISWAS, N., TAYLOR, K. E. (1999). Removal of phenolic compounds from synthetic wastewater using soybean peroxidase. Wat. Res., 33: $13: 3012-3018$.

CÉJKOVÁ, A., MASÁK, J. JIRKÚ, V., FIALOVÁ, A., MOENANDAR, D. (2002). The level of phenol hydroxilase in Candida maltosa - the key activity for efficient aromatic compound biodegradation. In: International Conference on waste management and the environment. Wit Press, Boston, MA, 99 - 106.

CERETI, C. F., ROSSINI, F., FEDERICI, F., QUARANTINO, D., VASSILEV, N., FENICE, M. (2004). Reuse of microbially trated olive mill wastewater as fertiliser for wheat (Triticum durum Desf.). Bioresource Technology. 91: 2: 135 - 140.

CERNIGLIA, C. E. (1997). Fungal metabolism of polycyclic aromatic hydrocarbons: past, present and future applications in bioremediation. J. Ind. Microbiol. Biotechnol. 19: $324-333$. 
CHANG, Y. J., NISHIO, N., NAGAI, S. (1995). Characteristics of granular methanogenic sludge grown on phenol synthetic médium and methanogenic fermentation of phenolic wastewater in a UASB reactor. Journal of Fermentation and Bioengineering. 79: 4: $348-353$.

CIAFARDINI, G., ZULLO, B. (2002). Survival of microorganisms in extra virgin olive during storage. Food Microbiology. 19: 105 - 109.

CONCEIÇÃO, D. M., ANGELIS, D. A. de, BIDOIA, E. D., ANGELIS, D. de F. de. (2004). Arq. Inst. Biol. 71: 4: 99 - 106.

COSTA, J. M., CORBEllini, V. A., SCROFERNEKER, M. L. (2004). Study of different nitrogens sources on glucose uptake and production of melanin precursos and fungal mass of Fonsecaea pedrosoi cultered in tricyclazole. Process Biochemistry. 39: $633-636$.

COUTO, R. S., SANROMÁN, M. A., HOFER, D. GÜBITZ, G. M. (2004). Stainless steel aponge: a novel carrier for the immobilisation of the White-rot fungus Trametes hirsuta for decolourization of textile dyes. Bioresorce Technology. 95: 67 - 72.

DAMASCENO, S., CEREDA, M. P., PASTORE, G. M., OLIVEIRA, J. G. (2003). Production of volatile compounds by Geotrichum fragrans using cassava wastewater as substrate. Process Biochemistry. 39: $411-414$.

D’ANNIBALE, A., CRESTINI, C., VINCIGUERRA, V., GIOVANNOZZI SERMANNI, G. (1998). The biodegradation of recalcitrant effluents from na olive-mill by a white-rot fungus. Journal of Biotechnol. 61: $209-218$. 
D’ANNIBAlE, A., RICCI, M., QUARANTINO, D., FEDERICI, F., FENICE, M. (2004). Panus tigrinus efficiently removes phenols, color and organic load from olivemill wastewater. Research in Microbiology. 155: 596 - 603.

D’ANNIBAlE, A., CASA, R., PIERUCCETTI, F., RICCI, M., MARABOTTINI, R. (2004). Lentinula edodes removes phenols from olive-mill wastewater: impact on durum wheat (Tricticum durum Desf. ) germinability. Chemosphere. 54: 887 - 894.

DEClERCK, S., STRUllu, D. G., PLENCHETTE, C., GUILlEMETTE, T. (1996). Entrapment of in vitro produced spores of Glomus versiforme in alginate beads: in vitro and vivo inoculum potentials. Journal of Biotechnology. 48: 51 - 57.

DEL RIO, D. T. (2004). Biossorção de cádmio por leveduras Saccharomyces cerevisiae. Dissertação (Mestrado em Agronomia, Escola Superior de Agricultura "Luiz de Queiroz”, Universidade de São Paulo). Piracicaba, 54p.

DENIZLI, A., CIHANGIR, N.; YOUSEFI RAD, A., TANER, M., GÜlEREN, A. (2004). Removal of chlorophenols from synthetic solutions using Phanerochaete chrysosporium. Process Biochemistry. 39: 2025-2030.

DHOUIB, A., ALOUI, F., HAMAD, N., SAYADI, S. (2006). Pilot-plant treatment of olive mill wastewater by Phanerochaete chrysosporium coupled to anaerobic digestion and ultrafiltration. Process Biochemistry, v. 41, i. 1, jan., p. 159 - 167.

FADIL, K., CHAHLAOUI, A., OUAHBI, A., ZAID, A., BORJA, R. (2003). Aerobic biodegradation and detoxification of wastewaters from the olive oil industry. International Biodeterioration \& Biodegradation. 51:1: 37 - 41. 
FIALOVÁ, A., BOSCHKE, E., BLEY T. (2004). Rapid monitoring of the biodegradation of phenol-like compounds by the yeast Candida maltosa using BOD measurements. International Biodeterioration \& Biodegradation. 54: 69 - 76.

FIELD, J. A., LETINGA, G. (1991). Treatment and detoxification of aqueous spruce bark extracts by Aspergillus niger. Water Science and Technology. 24: 127.

FOGARTY, R., TOBIN, J. M. (1996). Fungal melanins and their interactions with metals. Enzyme and Microbial Technology. 19: 311 - 317.

GHARSALlAH, N., LABAT, M., ALOUI, F., SAYADI, S. (1999). The effect of Pahanerochaete chrysosporium pretreatment of olive mill waste waters on anaerobic digestion. Resources, Consevation and Recycling. 27: 187 - 192.

GARCIA, I. G., PEÑA, P. R. J., VENCESLADA, J. L. B., MARTIN, A. M., MARTIN, M. A. S., GÓMEZ, E. R. (2000). Removal of phenol compounds from olive Mill wastewater using Phanerochaete chrysosporium, Aspergillus niger, Aspergillus terreus and Geotrichum candidum. Process Biochemistry, 35: 751 - 758.

GARCÍA, I. G., VENCESLADA, J. L. B., PEÑA, P. R. J. (1997). Biodegradation of phenol compounds in vinasse using Aspergillus terreus and Geotrichum candidum.Water Research. 31: 8: 2005 - 2001.

GARCÍA-PEÑA, E. I., HERNANDEZ, H., FAVELA-TORRES, E., AURIA, R. REVAH, S. (2001). Toluene biofiltration by the fungus Scedosporium apiospermum TB1. Biotechnology and Bioengineering. 76: 1: $61-69$. 
GOYAL, N., JAIN, S. C., BANERJEE, U. C. (2003). Comparative studies on the microbial adsorption of heavy metals. Advances in Environmental Research. 7: 311 319.

GRIFFIN, D. H. (1994). Fungal Physiology. Wiley-Liss, New York.

GUimarÃES, C., PORTO, P., OLIVEIRA, R., MOTA, M. (2005). Continuous decolorization of sugar refinary wastewater in a modified rotating biological contactor with Phanarochaete chrysosporium immobilized on poliuretane foam disks. Process Biochemistry. 40: $535-540$.

HARRISON, I., WILLIAMS, G. M., HIGGO, J. J. W., LEADER, R. U., KIM, A. W., NOY, D. J. (2001). Microcosm studies of microbial degradation in a coal tar distillate plume. Journal of Contaminant Hydrology. 53: 319 - 340.

HOLUM, J. R. (1994). Fundamentals of general organic and biological chemistry. Jhon Willey \& Soons, ins.

HUANG, C. P., WESTMAN, D., QUIRK, K. HUANG, J. P. (1988). The removal of cadmium II from dilute aqueous solutions by fungal adsorbent. Water Science and Technology 20: 369 - 376.

HWANG, S. C., LIN, C. S., CHEN, I. M, CHEN, J. M., LIU, L. Y., DODDS, W. K. (2004). Removal of multiple nitrogenous wastes by Aspergillus niger in a continuous fixed-slab reactor. Bioresource Technology. 93: 131 - 138.

IMAI, Y., ISHIKAWA, K., AYO, R. D., SUZUKI, M., MATSUMURA, M., KATAOKA, H. (1995). Repression of mycelia extension from a support carrier 
containing immobilized growing Aspergillus oryzae. Journal of Fermentation and Bioengineering. 79: $79-82$.

INIESTA, J., GONZÁlEZ-GARCÍA, J., EXPÓSITO, E., MONTIEL, V., ALDAZ, A. (2001). Influence of chloride ion on electrochemical degradation of phenol in alkaline medium using bismuth doped and pure $\mathrm{PbO}_{2}$ anodes. Wat. Res. 35: 14: 3291 - 3300.

IYENGAR, L., PRABHAKARARAO, A. V. S. (1973). Metabolism of chlorodane and heptachlor by Aspergillus niger. Journal of General and Applied Microbiology. 19: 321 - 324 .

JACOBSEN, T., HINRICHSEN, L. (1997). Bioformation of flavour by Penicillium candidum, Penicillium nalgiovense and Geotrichum candidum on glucose, peptone, maize oil and meat extract. Food Chemistry. 60: 3: 409 - 416.

JUAREZ-RAMÍREZ, C., RIUZ-ORDAZ, N., CRISTIANI-URBINA, E., GALÍNDEZMAYER, J. (2001). Degradation kinetics of phenol by immobilized cells of Cândida tropicalis in a fluidized bed reactor. World J. Microbiol. Biotechnol. 17: 697 - 705.

KAPDAN, I. K., KARGI, F. (2002). Simultaneous biodegradation and adsorption of textile dyestuff in an activated sludge unit. Process Biochemistry. 37: 973 - 981.

KAPOOR A., VIRARAGHAVAN, T., CULLIMORE, D. R. (1999). Removal of heavy metals using fungus Aspergillus niger. Bioresource Technology. 70: 95 - 104.

KAUFFMANN, C., PETERSEN, B. R., BJERRUM, M. J. (1999). Enzymatic removal of phenols from aqueous solutions by Coprinus cinereus peroxidase and hydrogen peroxide. Journal of Biotechnology. 73: 71 - 74. 
KENEALY, W., DIETRICH, D. (2004). Growth and fermentation responses of Phanerochaete chrysosporium to $\mathrm{O}_{2}$ limitation. Enzyme and Microbial Technology. 34: $490-498$.

KIM, S. J., SHODA, M. (1999). Batch decolorization of molasses by suspended and immobilized fungus of Geotrichum candidum Dec 1. Journal of Bioscience and Bioengineering. 88: 5: $586-589$.

KIM, T.H., LEE, Y., YANG, J., LEE, B., PARK, C., KIM, S. (2004). Decolorization of dye solutions by a membrane bioreactor (mbr) using white-rot fungi. Desalination. 168: $287-293$.

KOTSOU, M., KYRIACOU, A., LASARIDI, K., PILIDIS, G. (2004). Integrated aerobic biological tratment and chemical oxidation with Fento's reagent for processing of green table olive wastewater. Process Biochemistry. 39: 1653 - 1660.

KOTTERMAN, M. J. J. (1998). Polycyclic aromatic hydrocarbon degradation by the white rot fungusBjerkandera sp. Strain BOS55. Wageningen, Netherlands, 104p. Thesis Wageningen Agricultural University.

KUNZ, A., REGINATTO, V., DURAN, N. (2001). Combined treatment of textile effluent using the sequence Phanerochaete chrysosporium - ozone. Chemosphere. 44: $281-287$.

KYRIACOU, A., LASARIDI, K. E., KOTSOU, M., BALIS, C., PILIDIS, G. (2005). Combined bioremediation and advanced oxidation of green table olive processing watewater. Process Biochemistry. 40: $1401-1408$. 
LACAZ, C. DA S., PORTO, E., HEINS-VACCARI, E. M., MELO, N. T. (1998). Guia para a identificação de fungos, actinomicetos e algas de interesse médico. São Paulo: SARVIER. 445p.

LAI, S. T., TSAI, T., WANG, T. C., CHENG, T. (2005). The influence of culturing environments on lovastain production by Aspergillus terreus in submerged cultures. Enzyme and Microbial Technology. 36: 737 - 748.

LANGFELDER, K., STREIBEL, M., JAHN, B., HAASE, G., BRAKHAGE, A. A. (2003). Biosynthesis of fungal melanins and their importance for human pathogenic fungi. Fungal Genetics and Biology. 38: 143 - 158.

LUKE, A. K., BURTON, S. G. (2001). A novel application for Neurospora crassa: progress from batch culture to a membrane bioreactor for the bioremediation of phenols. Enzyme and Microbial Technology. 29: 348 - 356.

MARTIRANI, L.; GIARDINA, P.; MARZULLO, L.; SANNIA, G. (1996). Reduction of phenol content and toxity in olive oil mill waste waters with the lignolitic fungus Pleurotus ostreatus. Wat. Res. 30: 8: 1914-1918.

MARZZOCO, A., TORRES, B. B. (1999). Bioquímica básica. 2a ed. Rio de Janeiro, Ganabara Koogan. 360p.

METCALF, EDDY. (1991). Wastewater engineering: treatment, disposal and reuse. $3^{\mathrm{a}}$ ed. New York: Mc Graw-Hill. 1334p.

MINISTÉRIO DA SÚDE (1990). Portaria 36/GM. 
MINISTÉRIO DA SAÚDE (2004). Portaria GM n ${ }^{\circ} 518$ de 2004.

MIRANDA, M. P., BENITO, G. G., SAN CRISTOBAL, N., HERAS NIETO, C. (1996). Color elimination from molasses wastewater by Aspergillus niger. Bioresource Technology. 57: $229-235$.

MUKHOPADHYAY, R., CHATTERJEE, S., BANERJEE, P. C., GUHA, A. K. (2005). Production of gluconic acid from whey by free and immobilized Aspergillus niger. Internacional Dairy Journal. 15: $3: 299$ - 303.

NAGARATHNAMMA, R., BAJPAI, P., BAJPAI, P. K. (1999). Studies on decolourization, degradation and detoxification of chlorinated lignin compounds in Kraft bleaching effluents by Ceriporiopsis subvermispora. Process Biochemistry. 39: $939-948$.

NIELSEN, J. (1992). Modelling the growth of filamentous fungi. Advances in Biochemical Engineering/Biotechnology. 46: 187 - 223.

NILSSON, I., MATTIASSON, B., RUBINDAMAYUGI, M.S.T., WELANDER, U. (2006). Decolorization of synthetic and real textile wastewater by the use of white-rot fungi. Enzyme and Microbial Technology, v. 38, i. 1 - 2, jan, p. 94 -- 100.

NÓBREGA, J. A., MOZETO, A. A., ALBERIC, R. M., GUIMARÃES, J. L. (1995). A flor injection spectrophotometric determination of ammoniun in natural water. J. Braz. Chem. Soc. v. 6, n. 4, p. $327-330$.

O’DONNELL, D., WANG, L., XU, J., RIDGWAY, D., GU, T., MOO-YOUNG, M. (2001). Enhanced heterologous protein in Aspergillus niger through pH control of extracellular portease activity. Biochemical Engineering Journal. 8: 187 - 193. 
O'TOOLE, G., KAPLAY, H. B., KOLTER, R. (2000). Biofilm formation as microbial development. Annual Reviews in Microbiology, 54: 49 - 79.

PAMBOUKIAN, C. R. (1997). Influência das condições de preparo de inóculo na morfología do microrganismo e na síntese de glicoamilase por Aspergillus awamori. Dissertação (Mestrado em Engenharia Química, Escola Politécnica da Universidade de São Paulo).

PAPAGIANNI, M. (2004). Fungal morphology and metabolito production in submerged mycelial processes. Biotechnology Advances. 22: 189 - 259.

PEÑA-MIRANDA, M., BENITO, G., CRISTOBAL, N. S., NIETO HERAS, C. (1996). Color elimination from molasses wastewater by Aspergillus niger. Bioresource Technology. 57: $229-235$.

PETRE, M., ZARNEA, G. ADRIAN, P., GHEORGHIU, E. (1999). Biodegradation and bioconversion of cellulose wastes bacterial and fangal cells immobilized in radiopolymerized hydrogels. Resources, Conservation and Recycling. 27: 309 - 332.

PIETRO, M. B., HIDALGO, A., SERRA, J. L., LLAMA, M. J. (2002). Degradation of phenol by Rhodococcus erythropolis UPV-1 immobilized on biolite $\mathbb{B}$ in a packed-bed reactor. Journal of Biotechnology. 97: $1-11$.

PINTO, L. S., VIEIRA, L. M., PONS, L. N., FONSECA, M. M. R., MENEZES, J. C. (2004). Monitorização de processos biológicos: análise digital de imagens. Boletim de Biotecnologia. $15-21$. 
PRENAFETA BOLDÚ, F. X. (2002). Growth of fungi on volatile aromatic hydrocarbons: environmental technology perspectives. Thesis. Wageningen University. Wageningen, 115p.

PRINCE, M. S., CLASSEN, J. J., PAYNE, G. A. (2001). Aspergillus niger absorbs copper and zinc from swine wastewater. Bioresource Technology. 77: 41 - 49.

RAGHUKUMAR, C., MOHANDASS, C., KAMAT, S., SHAILAJA, M. S. (2004). Simultaneous detoxification and decolorization of molasses spent wash by the immobilized white-rot fungus Flavodon flavus isolated from a marine habitat. Enzyme and Microbial Technology. 35: 197 - 202.

RAHOUT, M., STEIMAN, SEIGLE-MURANDI, F., CHRISTOV, L. (1999). Growth of 1044 strains and species of fungi on 7 phenolic lignin model compounds. Chemosphere. 38: 11: 2549 - 2559.

RAO, J. R., VIRARAGHAVAN, T. (2002). Biosorption of phenol from an aqueous solution by Aspergillus niger biomass. Bioresource Technology. 85: 165 - 171.

RODRIGUES, K. A. (1999). Tratamento biológico de água residuária sintética de laticínios por decomposição fúngica. Dissertação (Mestrado em Engenharia Civil, área de concentração em Saneamento Ambiental, Universidade Federal do Ceará). Fortaleza. $113 \mathrm{p}$.

RODRIGUES, K. A., SAMPAIO, G. M. M. S., ZAIAT, M., SANTAELlA, S. T. (2004). Redução da concentração de fenol pelo uso de reatores biológicos com fungos. In: XI Simpósio Luso-Brasileiro de Engenharia Sanitária e Ambiental - SILUBESA. Abril, 2004 (pp 58 - 59), Natal, RN. 
ROSAS, A. L., NOSANCHUK, J. D., GÓMEZ, B. L., EDENS, W., HENSON J. M., CASADEVALL, A. (2000). Isolation and serological analyses of fungal melanins. Journal of Immunological Methods. 244: 69 - 80.

SÁ, I.M.B. (1997). Biotratamento de efluente de uma indústria de laticínios por ação de fungos decompositores. Dissertação (Mestrado em Engenharia, Universidade Federal do Ceará). Fortaleza. 83p.

SAHOO, D. K., GUPTA, R. (2005). Evaluation of lignolytic microorganisms for efficient decolorization of a small pulp and paper mill effluent. Process Biochemistry, $\mathrm{v}$. 40 , i. $3-4$, p. $1573-1578$.

SAMPAIO, G. M. M. S., SANTOS, E. A., FACÓ, A. M., LEITÃO, R. C., MENEZES, E. A., SANTAELlA, S. T. (2004). Pós-tratamento de efluente de um reator UASB através de um reator biológico com fungos. Associação Brasileira de Engenharia Sanitária e Ambiental, v. 9, n. 1, p. 73 - 81.

SAMPAIO, G. M. M. S. (2005). Remoção de metil paration e atrazina em reatores com fungos. Tese (Doutorado em Hidráulica e Saneamento, Escola de Engenharia de São Carlos, Universidade de São Paulo). São Carlos, 115p.

SAND, W. (1997). Microbial mechanisms of deterioration of inorganic substrates $-a$ general mechanistic overview. International Biodeterioration \& Biodegradation. 40: 2: $183-190$.

SANGTIEAN, T., SCHMIDT, S. (2002). Growth of subtropical EMC fungi with different nitrogen sources using a new flotation culture technique. Mycol. Res. 106: 1: $75-85$. 
SANKPAL, N. V., KULKARNI, B. D. (2002). Optimization of fermentation conditions for gluconic acid production using Aspergillus Níger immobilized microfibrils. Process Biochemistry. 37: $1343-1350$.

SANTAELLA, S. T. (1993). Remoção de cor causada pela presença de substâncias húmicas em águas, empregando tratamento biológico. Tese (doutorado) Escola de Engenharia de São Carlos. São Carlos - SP. 161p.

SANTAELlA, S. T., CAMPOS, J. R., LINARES, I. L. (1996). Perspectivas de remoção de cor (substâncias húmicas) de águas destinadas ao abastecimento público mediante tratamento biológico. Revista Engenharia Sanitária e Ambiental: 1: 1: 13-17.

SANTAELLA, S. T. (1999). Estudos de tecnologias apropriadas para tratamento de efluentes da indústria de castanha de caju. Fortaleza: UFC, Departamento de Engenharia Hidráulica e Ambiental, 31p. (Relatório Institucional de Pesquisa).

SANTOS, V. L., LINARDI, V. R. (2004). Biodegradation of phenol by a filamentous fungi isolated from industrial effluents - identification and degradation potential. Process Biochemistry. 39:1001 - 1006.

SCOW, K. M., LI, D., MANILAL, V. B., ALEXANDER, M. (1990). Mineralization of organic compounds at low concentrations by filamentous fungi. Mycolo. Res. 94: 6: 793-798.

SEKHAR, K. C., SUBRAMANIAN, S., MODAK, J. M, NATARAJAN, K. A. (1998). Removal of metal ions on industrial biomass with reference to environmental control. International Journal of Mineral Processing, 53: 107 - 120. 
SOUZA, J. V., E. S. da SILVA, F. T. da Silva, T. C. B. PAIVA (2005). Fungal treatment of delignification effluent from a nitrocellulose industry. Bioresource Technology, v. 96, i. 17, p. 1936 - 1942.

SWIFT, R. J., KARANDIKAR, A., GRIFFEN, A. M., CEES, P. J. P., van den HONDLEY, A. M. J. J., ROBSON, G. D., TRINCI, A. P. J., WIEBE, M. G. (2000). The effect of organic nitrogen source on recombinant glucoamylase production. Fungal Genetics and Biology. 31: 125 - 133.

TIMUR, S., PAZARlioglu, N., PILlOTON, R., TELEFONCU, A. (2004). Thick film sensors based on laccases from different sources immobilized in polyaniline matrix. Sensors and Actuators. 92: 132 - 136.

THE MERCK INDEX (1996). An encyclopedia of chemicals, drugs and biologicals. Published by Merck Research Laboratories. $20^{\text {th }}$ ed.

TRABUSi, L. R., Alterthum, F., GOMTERTZ, O. S., CANDEIAS, J. A. N. (1999). Microbiologia. São Paulo. Editora Ateneu, $3^{\underline{a}}$ ed. 588p.

van SCHIE, P. M., YOUNG, L. Y. (2000). Biodegradation of phenol: mechanisms and applications. Bioremediation Journal. 4: 1: 1 - 18.

VASSILEV, N., FENICE, M., FEDERICI, F., AZCON, R. (1997). Olive mill wate water treatment by immobilized cells of Aspergillus niger and its enrichment with soluble phosphate. Process Biochemistry. 32: 7: 617 - 620.

VILLENA, G. K., GUTIÉRREZ-CORREA, M. (2003). Aspergillus niger biofilmes for celulasas production: some structural and physiological aspects. Rev. Peru. Biol. 10: 1: $78-87$. 
VINCIGUERRA, V., D’ANNIBALE, A., MONACHE, G. D., SERMANNI, G. G. (1995). Correlated effects during the bioconversion of waste olive waters by Lentinus edodes. Bioresourse Technology. 51: 2211 - 276.

WALlSTRÖM, S., DOWLING, K., KARLSSON, S. (2002). Development and comparasion of test methods for evaluating formation of biofilms on silicones. Polymer Degradation. 78: $257-262$.

WITTEVEEN, C. F. B. (1993). Gluconate formation and polyol metabolism in Aspergillus niger. Thesis. Wageningen University. Wageningen, 128p.

WOERTZ, J. R., KINNEY, K. A., McINTOSH, N. D. P., SZANISZLO, P. J. (2001). Removal of toluene on a vapor-phase bioreactor containg a strain of the dimorphic black yeast Exophilia lecanii. Biotechnol. Bioeng. 75: 550 - 558.

WRIGHT, J. D. (1993). Fungal degradation of benzoic acid and related compounds. World Journal Microbiology and Biotechnology. 9: 19- 26.

WU, J., XIAO, Y., YU, H. (2005). Degradation of lignin in pulp mill wastewaters by white-rot fungi on biofilm. Bioresource Technology. 96: 1357 - 1363.

XIAO, J. H., CHEN, D. X., XIAO, Y., LIU, J. W., LIU, Z. L., WAN, W. H., FANG, N., TAN, B. B., LIANG, A. Y. (2004). Optimization of submerged culture conditions for mycelial polysaccharide production in Cordyceps pruinosa. Process Biochemistry. 39: $2241-2247$.

ZEHNDER, A. J. B. (1988). Biology of anaerobic microorganisms. John \& Sons. New York. 468p. 